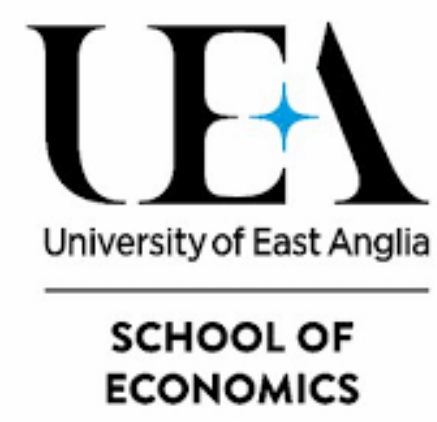

\title{
The declining fortunes of (most) American workers 2020-04
}

Laura A. Harvey

James Rockey

www.uea.ac.uk/economics 


\title{
The declining fortunes of (most) American workers
}

\author{
Laura A. Harvey* \\ James Rockey \\ University of East Anglia \\ University of Leicester
}

6th August 2020

\begin{abstract}
While real US GDP per capita has increased around 80\% since 1980, median incomes have remained roughly constant. However, as this paper documents, this stagnation masks an important decline. Male median real incomes have been lower than that of their forebears, at every age, for the last 30 years. We show that this is true across the life cycle and across the wage distribution. Moreover, younger generations have also had to wait longer to reach peak earnings. Further analysis shows that this decline is particularly concentrated on high school graduates. The same pattern is found for female high school graduates yet, African American and Hispanic American women are an important exception. Variance decompositions suggest that these intergenerational differences are quantitatively important. While reductions in hours worked cannot explain the decline, substantial decreases in the labour share are consistent with decreasing incomes in the face of productivity growth. Calculations suggest that hedonic improvements in the quality of goods and services would have to have been equivalent to $30 \%$ of younger cohorts' lifetime consumption for their consumption levels to match those of their predecessors.
\end{abstract}

Keywords: Wages, Intergenerational Differences, Labour Share, Stagnation, Jobs

JEL Codes: E24, J24, J31, D33, D31

*Email: laura.a.harvey@uea.ac.uk and jamesrockeyecon@gmail.com. We thank Jonathan Temple, Brad Larsen, Adam Rosen, Cheng Chou and Sebastian Cortes-Corrales as well as seminar participants at Leicester and Groningen for their insightful comments. 


\section{Introduction}

Many of us take economic progress for granted. We expect that normally our earnings will increase from one year to the next and that we will be more prosperous than our parents and grandparents were. Yet, this expectation is increasingly misaligned with recent experience. US real median earnings have seen little improvement since $1980 .{ }^{1}$ Meanwhile, US GDP per capita has nearly doubled since $1980 .^{2}$ This increase reflects both growth in women's market earnings due to greater labour market participation as well as increases in the earnings of the richest.

This paper studies this stagnation from an intergenerational perspective. We trace the real earnings of each generation over the life cycle and document that for each generation subsequent to the Baby Boomers, living standards have declined substantially in real terms. That is, rather than being richer than their parents, the median member of Generation X, born between 1965-1979, or a Millennial born in the period 1980-1999, is poorer at every point during their working lives than their parents were as members of either the Boomer or Silent Generations, born between 1946-1964 or 1925-1945 respectively.

Figure 1 shows median earnings in 1999 dollars at each age for white, male, high-school educated, Americans by decade of birth. Comparing the median wage across cohorts, we see that those born in the 1920 s, were earning over $\$ 30,000$ in by their early 30s. This is less than those born in the 1930 s and the 1940s, but interestingly this cohort have the highest peak earnings of any cohort, at around $\$ 55,000$. However, the 1940 s cohort saw their wages drop by nearly a quarter in real terms at the beginning of the 1980s relative to their wages in the preceding decade and never recover. A similar change seems to affect the previous cohorts, but later in life where it is conflated with retirement. Cohorts from the 1950s onwards, see comparatively little wage growth, earning less at every point in their lives than their forebears. For example, a white male high-school graduate born in the 1930s is earning about $\$ 50,000$ by age 40 , their son, born in the 1950 s, makes $\$ 40,000$, their grandson born in the 1970s had a median wage around $\$ 35,000$. Chetty et al. (2014) documents the growing importance of the 'birth lottery', our results imply the average ticket is now a losing one in absolute terms.

The purpose of this paper is to study this phenomenon of intergenerational declines in median wages. The first section of this paper discusses intergenerational changes in earnings, providing evidence of similar patterns, with few exceptions, across demographic groups, and the population as a whole. In particular, we find that the median earnings of male college graduates have also declined. This is also true for women with the exception of the Silent Generation, as well as African American

\footnotetext{
${ }^{1}$ See Figure B.1 in the Appendix.

${ }^{2}$ Measured in 2010 Dollars, it was \$28,589 in 1980 and \$54,551 in 2018. Data from: https://data. worldbank. org/indicator/NY.GDP.PCAP.KD?locations=US
} 
and Hispanic men. The key exception has been the substantial improvement in the earnings of African American and Hispanic women. Both graphical analysis at the cohort level, as well individual level regression estimates, show that this is a general phenomenon. Considering conditional demographic and educational controls, we find that Boomers' earnings were slightly lower than the Silent Generation's, whilst Gen. X'ers and Millennials were earning $6 \%$ and $12 \%$ less than the Silent Generation, respectively. We also show that, as well as earnings being lower, later generations have had to wait longer to attain peak earnings.

We show that a reduction in hours worked between generations cannot explain these declines and given that overall, the US has grown strongly throughout the period we study (Jorgenson et al., 2008, Bloom et al., 2012) another explanation is necessary. Thus, the second part of this paper builds on the recent literature documenting and analysing the declining US labour share to argue that intergenerational differences in the labour share are, in part, responsible for declining US real wages. We find evidence that the labour share is indeed lower for Millennials compared to Boomers.

Following this, we look at heterogeneous effects across the distribution. To do this we estimate a number of quantile regressions and plot the trends for each generation for men and women separately, and then by education and ethnic background. Our results imply that women and non-Whites in the lowest quantiles have seen real income growth yet the majority saw declines.

We next perform a variance decomposition analysis which shows that while generation cannot explain much of the variation in wages after accounting for changes in the distribution of wages over states and sectors and education and demographic characteristics that it is still an important determinant of the labour share. We argue that this implies that decline in real wages is driven, in part, by reductions in the labour share.

A potential concern is that our focus on real wages means that we do not adequately capture improvements in the quality of goods and services, or improvements in working conditions. In the final part of the paper we study this argument quantitatively, asking what level of hedonic improvement would be necessary to compensate for the observed differences in income. We begin by assuming logutility for tractability and focusing only on differences in earnings. This suggests the relative lifetime quality level would need to be around $20 \%$ higher for those born in the 1970s compared to those born in the 1920s. We consider an isoelastic utility function that also includes the disutility of work as in Mankiw and Weinzierl (2006), to analyse the limitations of this approach.

This paper is part of a nascent literature that studies the comparative fortunes of different cohorts. There are two recent papers, Guvenen et al. (2017) and Borella et al. (2019) that also take a cohort approach to life cycle earnings and similarly document the decline in the incomes of younger genera- 
Figure 1: Median wage of white male high school graduates, by decade of birth, over the life cycle

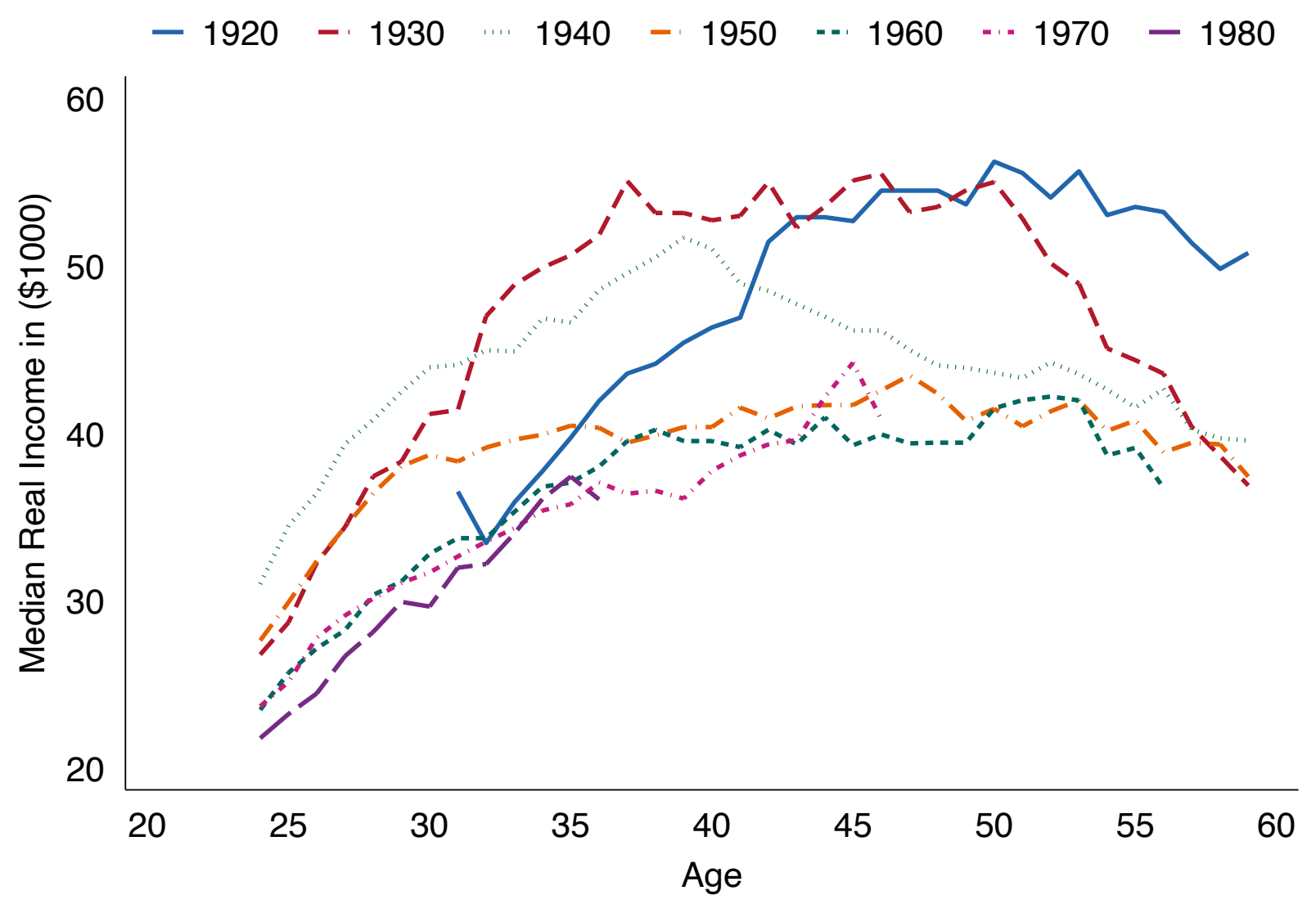

Source: Current Population Survey (CPS)

Notes: Includes the male population between the ages of 23 and 65 who are high school graduates and have wages above the defined minimum income threshold. Wages are adjusted for inflation and individual weights are used.

tions. $^{3}$ To our knowledge Guvenen et al. (2017) is the first to provide evidence of this. They use an extract from the US Social Security Administration register data to show that total lifetime income is at least $10 \%$ lower for the most recent cohort they study (those entering the labour market in 1983) compared to the first (those entering in 1957). Importantly, they are able to rule out a substantial effect of non-pay benefits such as employer provided health insurance and pensions or the choice of price deflator. An important second contribution of their paper is to study the evolution of gender differences in incomes between men and women across cohorts. The lifetime earnings of the median woman have converged towards that of the median man, from $37 \%$ for the 1957 cohort, to $60 \%$ for the 1983 cohort, with this being partially driven by an increase in the number of years worked by younger women (aged 25-34) but mainly by increasing incomes of those women in work. Interestingly, while this reduction in earnings differences between men and women has reduced within-cohort inequality,

\footnotetext{
${ }^{3}$ Acemoglu and Autor (2011) document the declining income of lower skilled workers but not the disparity across generations.
} 
this reduction has been offset by an increase in income inequality within each gender group. Moreover, while an analysis of more recent cohorts suggested continued growth in women's earnings until 1998, they have subsequently stagnated - although, as they caution, this may reflect the consequences of the Financial Crisis. Finally, they adopt a slightly different perspective and analyse the distribution by decile and gender of the total income of each cohort. They show that, while women's share has increased for every decile, that this increase has been larger for the highest earning, while only those in the top few percentiles of the male lifetime earnings distribution have seen an increase, with most experiencing a substantial decline.

The contribution of this paper is to complement the analysis of Guvenen et al. (2017) by using the CPS to document the important heterogeneity in these trends, and to analyse what caused them. Exploiting these data, our analysis highlights not only substantial differences by education level, race, and gender but also industry and occupation. Moreover, we seek to understand the drivers of these patterns in terms of the changing geographic and sectoral distribution of economic activity, the declining labour share of income, and skill-biased technological change. Merging the CPS with the Economic Census further allows us to test the explanatory power of each of these trends. While the CPS is representative, covering workers in all industries since 1962, its key limitation is that it is a repeated cross-sectional survey, unlike the panel of Guvenen et al. (2017). However, our analysis is at the level of time-invariant groups, rather than individuals and so, suitably weighted, the data are sufficient for our purpose. ${ }^{4}$ Furthermore, we compliment their important discussion of the role of alternative deflators and non-pay benefits, with our analysis of the role of hedonic progress.

Borella et al. (2019) also take a generational approach and note that as well as Americans born in the 1960s having lower earnings than those born in the 1940s, that they have lower life expectancies and higher out of pocket medical expenses. Using the model introduced in Borella et al. (2017), which incorporates the behaviour of both single people and couples to calculate the effects of these three changes and find that they are equivalent to an asset transfer of $12.5 \%$ of their lifetime earnings or $\$ 126,000$ aged 25 . For single women the figures are $\$ 44,000(7.2 \%)$ and $\$ 132,000(8 \%)$ respectively. The aspect of this paper that is closest to what they do is Section 5 where we try to quantify the degree of hedonic progress that would equalise the value of consumption minus the disutility of work across generations.

Our focus on the labour share has much in common with an important recent literature that highlights the declining labour share. In that literature, the paper closest to this one is Autor and

\footnotetext{
${ }^{4}$ Similarly, Guvenen et al. (2017) use the CPS to test the robustness of their results, where they find similar trends compared to their use of panel data. The sample of social security data they use covers approximately $70 \%$ of private sector employment, as they restrict the sample to workers in commerce and industry.
} 
Salomons (2018) who provide evidence that automation has not led to reduced employment but can partly explain the decline in the labour share. They build on the framework introduced by Acemoglu and Restrepo (2018) which predicts that, while automation may reduce both wages and the labour share, along the balanced growth path this process is self-limiting as automation increases the productivity of labour and creates new tasks. Automation is only one of several secular trends that have been found to exert downwards pressure on the labour share. Autor et al. (2020) argue that another possible cause of the global decline in labour share is more productive firms (because of either globalisation or technological change) gaining higher concentration in their respective industries, creating so-called superstar firms. These firms have a higher mark-up and lower share of labour in sales and value added than compared with previous times. As a result, these firms are able to operate across multiple industries and so the within industry labour share will fall. Karabarbounis and Neiman (2014) show that the labour share of income is falling in most countries and attribute this decline to falls in the price of investment goods. Grossman et al. (2018) show that the slowdown in productivity growth in recent years may lead to a lower labour share. Böckerman and Maliranta (2011) working with Finnish data highlight the role of plant restructuring. Finally, Elsby et al. (2013) consider the roles of two other key recent trends: Unionisation and offshoring. They find little role for unionisation but emphasise the impact of offshoring.

While we focus on the absolute standard of living, Piketty (2018) links the declining labour share to increasing levels of inequality (Piketty and Saez, 2003, Saez and Zucman, 2016). Others have highlighted non-economic consequences of such trends. For example, our findings might be read through the lens of the argument by Friedman (2005), in which the lack of broad-based economic progress can risk the moral quality of society, particularly his argument that a lack of economic progress may imperil the quality of democracy. Likewise, Case and Deaton (2015) document increasing morbidity amongst those aged $45-54$, so called 'deaths of despair'.

This paper is organised as follows. The next section describes life cycle earnings profiles for different generations and sub-populations and discusses the role of hours worked. Section 3 provides evidence from individual level regression analysis and explores the role of the declines in the labour share. Section 4 reports the results of a variance decomposition analysis. Section 5 considers how much hedonic improvement in consumption would be necessary to equalise consumption levels across generations. Section 6 briefly concludes. 


\section{Life cycle earnings}

We will rely on the Current Population Survey (CPS) for the bulk of our analysis, as well as the Economic Census. Further discussion of these data and how we handle them may be found in Appendix A.

\section{$2.1 \quad$ Wages}

\subsubsection{Lifetime wages}

In this section we report results complementary to those of Guvenen et al. (2017), making use of the detailed demographic data in the CPS to disaggregate by race and education as well as gender. We also work with a slightly different sample. Guvenen et al. (2017) mostly focus on those cohorts who were 25 in 1957 to those who were 25 in 1983, such that they can follow each cohort for the ages 25-55, and define lifetime earnings over that period. This has the important advantage that education is largely complete by age 25 , and fewer people retire or otherwise leave the workforce before age 55 . We choose to focus on a longer time span - on those born between 1925 and 1994 - at the price of not being able to follow the last generation, the Millennials, throughout their lives. However, by now the oldest of these are nearly 40 and thus we are in position to compare their comparative fortunes to this point. This comparison is worthwhile because by around this age many Americans would hope to have bought a house, started a family, and to be earning close to their maximum real incomes. More generally, a standard discounting argument implies that an income profile that offers greater earnings early in one's life, holding total earnings constant, is to be preferred. Thus, the shape and level of each generation's earnings profile matters for welfare, and may be usefully compared by age 40 .

Table 1: Different birth cohorts.

\begin{tabular}{l|l}
\hline Year born & Birth cohort \\
\hline $2000-$ Present & Generation Z \\
$1980-1999$ & Millennials (Gen. Y) \\
$1965-1979$ & Generation X (Gen. X) \\
$1946-1964$ & Baby Boomers (Boomers) \\
$1925-1945$ & Silent Generation \\
\hline
\end{tabular}

For exposition purposes, we divide the Americans in our data into generations, as they are typically defined. Table 1 displays how we define each generation. The top-left panel of Figure 2 is analogous to Figure 1 except now the median wage over the life cycle is plotted by generation. We can see clearly that the Silent Generation (born 1925-1945 denoted by blue circles) have higher earnings at every point than the Boomers (purple diamonds), Gen. X'ers (green triangles) and Millennials (brown squares). Moreover, this difference is substantial, nearly $\$ 20,000$ a year at age 45 , or two thirds of 
Boomer earnings. While the Boomers earn less than the Silent Generation, they do earn more than the later two generations. Moreover, they hit peak earnings sooner, by their late 20s, while Gen. X'ers experienced a much slower growth in their earnings, even if they seem to have converged by age 50 . This is also true for Millennials. Figure 3 reports the same data but now with year rather than age on the horizontal axis. ${ }^{5}$ This makes clear the declining fortunes of high school graduates. Each generation's median wage at each age is below (excluding a drop off in earnings for the Silent Generation from age 50 onwards) that of the one before. The average across all generations, not plotted, thus declines as Gen. X'ers and Millennials start to replace the Silent Generation and Boomers. Note, that we might expect, given substantial economic growth, the opposite: that each generation would start from a higher point than the preceding one and increase from there such that the curves would intersect.

The bottom-left panel of Figure 2 presents results for men with at least some college education. We see that, again, the median wage of the Silent Generation is higher at all points in their career. This means that the decline of real wages has not only been experienced by high school graduates. Suggesting that the phenomenon is not limited to those in lower-skill occupations. But the difference with the Boomers is smaller now and there is no appreciable difference between the Boomers and the subsequent generations. This is consistent with skills-biased technological change advantaging those with more formal education in subsequent generations relative to those with less in their generation and thus reducing the gap between generations of the more educated. This explanation is also consistent with what seems to be some evidence of improved earnings for Millennials who attended college in the last couple of years relative to the Boomers and Gen. X'ers. But, without more data, it is not possible to rule out that this is just a short-term fluctuation.

Looking at the bottom-left panel of Figure 3 again reinforces the point. We again can see lower earnings at every point for each subsequent generation and more notably for this sample, pronounced generational differences in the rate of progress over the life cycle. This can be seen by comparing the difference between the Boomer's curve and that of Gen. X or the Millennials, which are substantially flatter at the beginning.

The blue line in the top-left panel of Figure 4 plots the maximum median wage reached by year born for male high school graduates. We then annotate these points (in green) with the age when this income was reached. We see that median American born in 1945 had maximum earnings of just over $\$ 65,000$ which they achieved age 47 . In comparison, the maximum median wage of those born 10-15 years later was substantially lower, but was achieved by their early 30s. Those born from around 1961

\footnotetext{
${ }^{5}$ Note, that there will be some difference in the estimates since Figure 2 takes the median of all members of a given generation at a given age. Figure 3 reports the median in a given year of all members of a generation who will hence be of a range of ages.
} 
Figure 2: Median wage (in $\$ 1000)$ by generation over the life cycle

Male High School Graduates

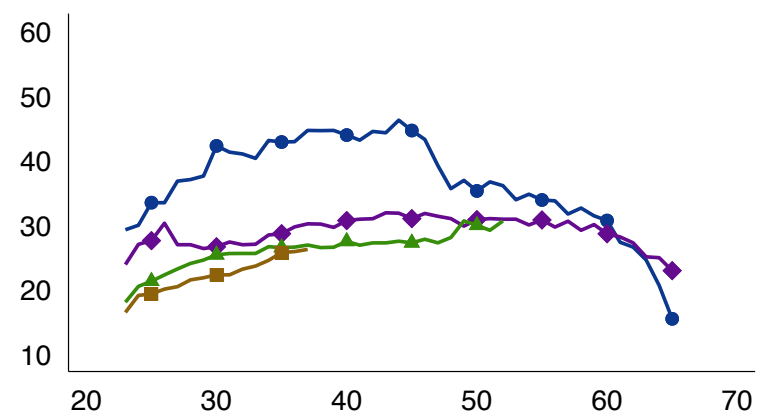

Males with College

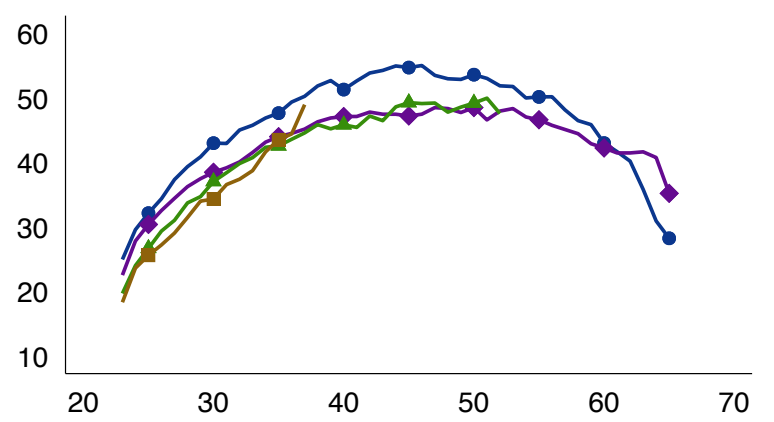

- Silent $\diamond$ Boomers
Female High School Graduates

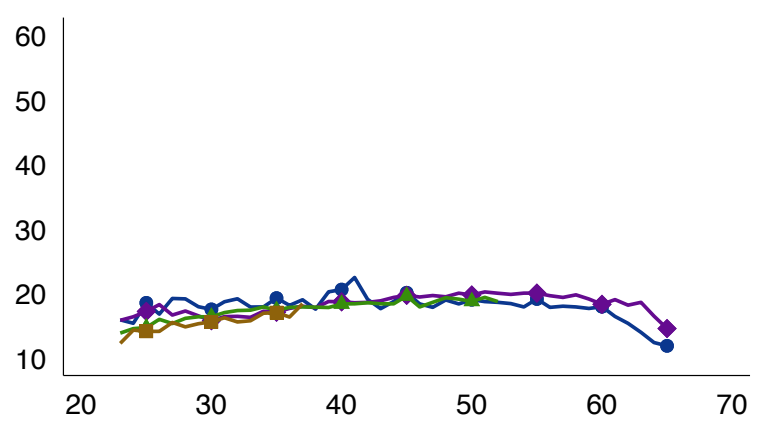

Females with College

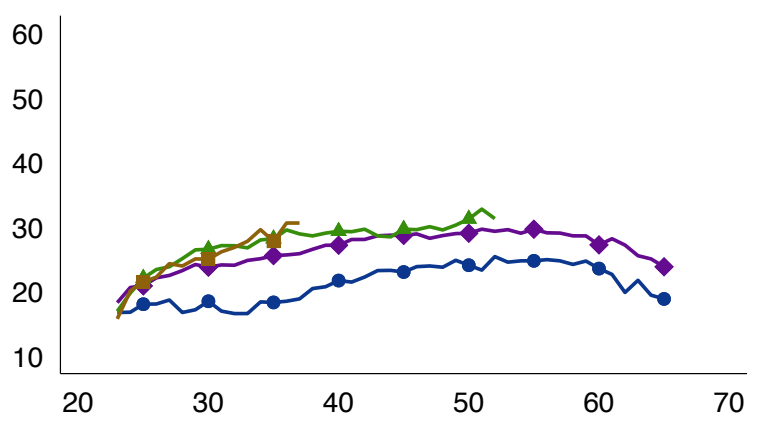

Gen. X Millennials

Source: Current Population Survey (CPS)

Notes: Includes the total population, wages are adjusted for inflation, and individual weights are used. 'some college' includes those who attended college and have at least a bachelor's degree. The vertical axis is median real wage in $\$ 1000$, measured in 1999 dollars.

to 1970 not only had lower maximum earnings but they did not receive them until they were 50. More recent cohorts had again lower maximum earnings, albeit slightly earlier at ages $42-44$. Given the effects of the Financial Crisis, it maybe premature to reach a conclusion about those born in the late 1970s as it is conceivable that their earnings will still increase meaningfully.

\subsubsection{By gender}

The right two panels of Figure 2 show the results of the same analysis for women. Looking first at the results for high school graduates in the top-right panel, it is clear that women's median earnings are on average, across the life cycle and across all generations, considerably lower than those of men. It is also clear that there is little progress across generations. This result is in contrast to the findings of Guvenen et al. (2017) and this may reflect differences in the origins of the data used and the sample definition. One appealing feature of Guvenen et al. (2017) is that they are able to use administrative data providing recorded rather than self-reported earnings data. A disadvantage of this is that it 
Male High School Graduates

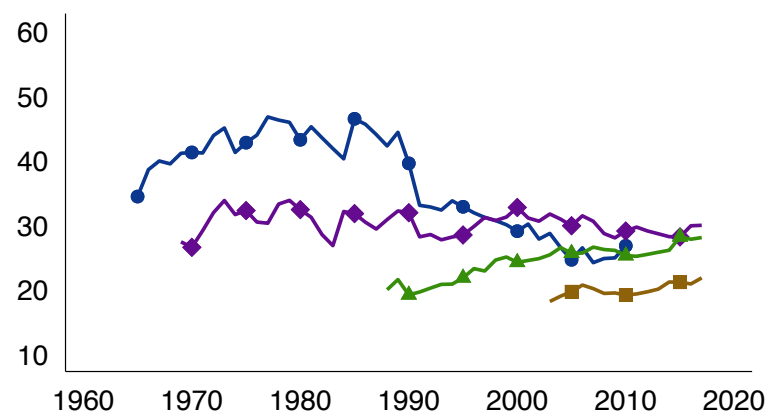

Males with College

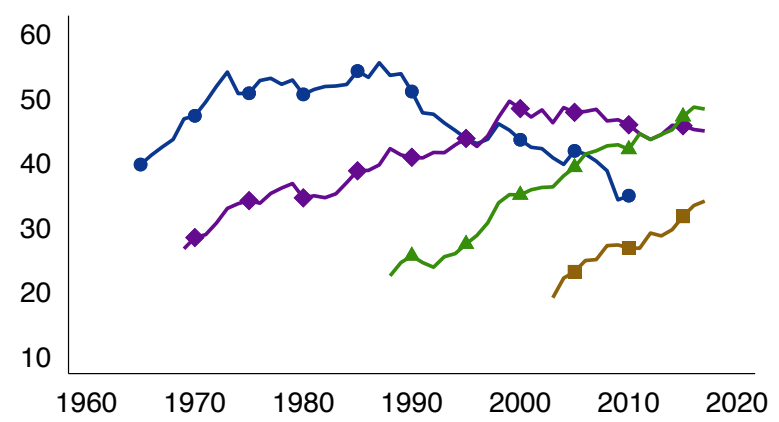

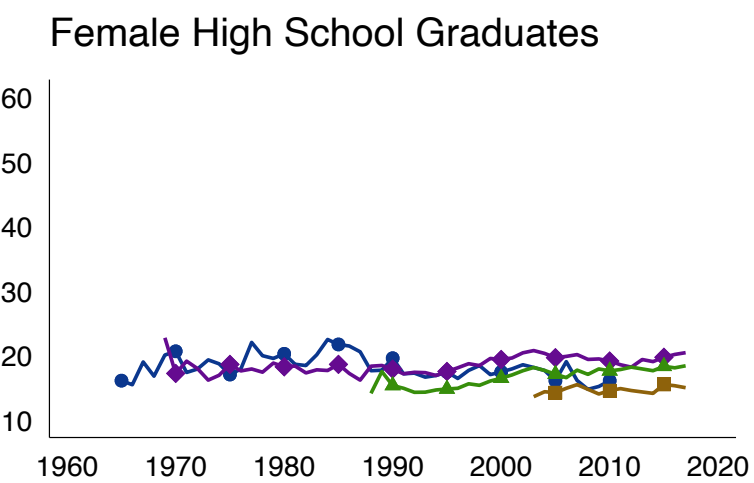

Females with College

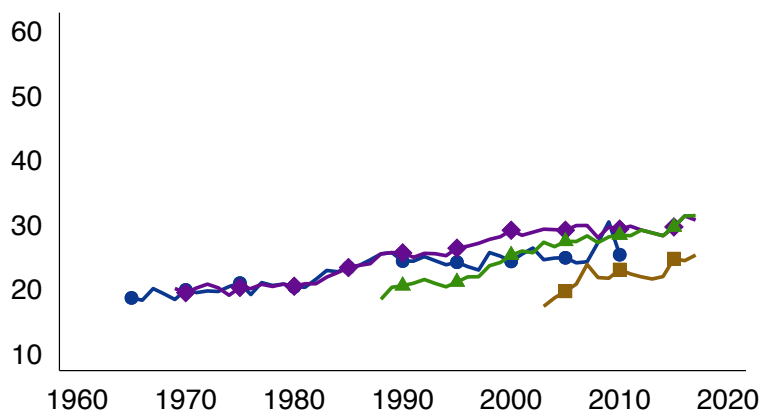

Gen. X Millennials

Source: Current Population Survey (CPS)

Notes: Includes the total population, wages are adjusted for inflation, and individual weights are used. 'some college' includes those who attended college and have at least a bachelor's degree. The vertical axis is median real wage in $\$ 1000$, measured in 1999 dollars.

may exclude unrecorded earnings, which our data should capture. Looking at the top right panel of Figure 3 we see that each generation seems to converge to within a few thousand dollars of a median of $\$ 20,000$.

The bottom-right panel of Figure 2 now shows the results for women who attended college. Here, the opposite story is true. Each generation seems to be out earning the one before it. Thus, the Silent Generation now has the lowest median wage, followed by the Boomers, the Gen. X'ers and finally Millennials. Consistent with this, in Figure 3 we now see this pattern of the median earnings of each cohort intersecting with those before it (albeit not yet for Millennials). This suggests, that perhaps the growth in women's earnings documented by Guvenen et al. (2017), are due solely to the growth in the earnings of college-educated women and the growth in the proportion of women attending college. ${ }^{6}$

\footnotetext{
${ }^{6}$ Guvenen et al. (2017) restrict the sample to those with consistent labour market engagement and a minimal level of income that may disproportionately exclude less-educated women, who may be more likely to be in informal employment.
} 
Male High School Graduates

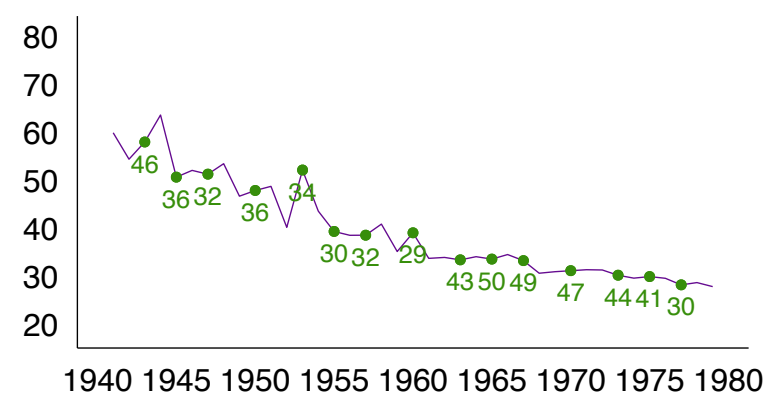

Males with College

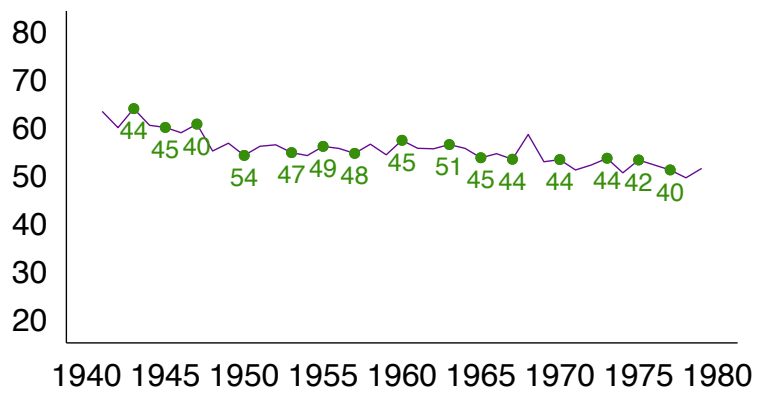

Female High School Graduates

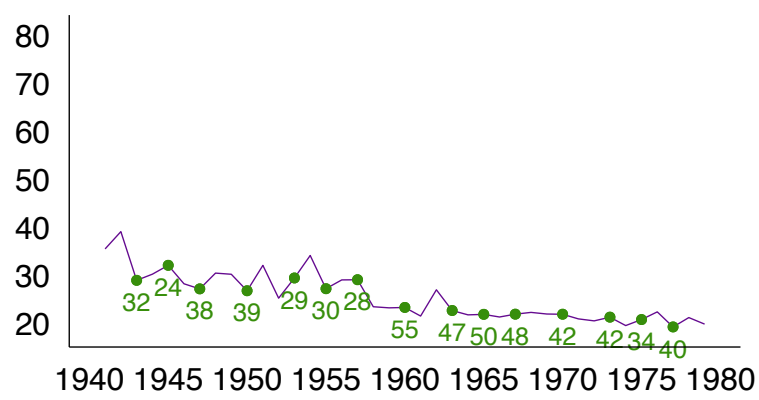

Females with College

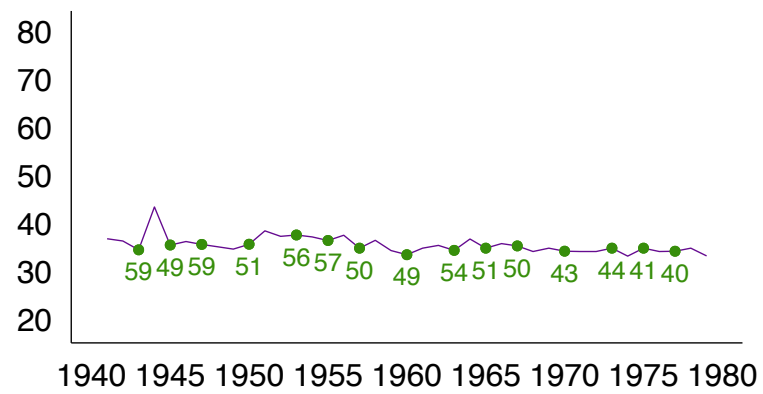

- Age Maximum Median Income Reached

Source: Current Population Survey (CPS)

Notes: Includes the total population, wages are adjusted for inflation, and individual weights are used. The vertical axis is median real wage in $\$ 1000$, measured in 1999 dollars. The line is the maximum median wage by each year born and the label refers to the age when this maximum median wage was achieved. 'some College' includes those who attended college and have at least a bachelor's degree.

\subsubsection{By race}

Another key margin of income inequality is race: African Americans and Hispanic Americans continue to have lower average incomes than other Americans (Fryer, 2011). Given that around the beginning of our sample period, the passage of the Civil Rights Act made discrimination on the basis of race illegal, and recent evidence suggests that discrimination can account for a relatively small proportion of the racial earnings gap (Fryer, 2011). Thus, we might expect subsequent generations of African American and Hispanic men to have higher incomes than those of the Silent Generation even if male earnings in general are declining. Similarly, we expect more rapid growth in the earnings of African American and Hispanic women. However, inspection of the top two panels of Figure 5 which reproduces Figure 2 for African American and Hispanic men suggests that this is not the case. Incomes at each point in the life cycle are broadly constant across all four generations of African American men. It is unclear why relative pay of the Hispanic Silent Generation was so much higher than subsequent 
generations, but focusing on the Boomers onwards we see no evidence of an increase in the wages of Hispanic men either, and indeed arguably a decline. Of course, migration makes comparisons across generations more difficult and it maybe that the lack of earnings growth is due to a composition effect. This would explain, potentially, the substantial decline in earnings from the Silent Generation to subsequent generations.

The bottom two panels report results for African American and Hispanic women, respectively. Now, we see clear signs of increasing incomes from one generation to the next. Looking first at the evidence for the African American women in the bottom left panel we see that working women of the Silent Generation earned around \$5,000 less than Boomers, who in turn earned less, albeit not as much less than Gen. X'ers and Millennials. A similar, but arguably more pronounced pattern can be seen in the bottom right panel for Hispanic women. Now, as well as daylight between the Silent Generation and the Boomers there is a clear difference between Boomers and Gen. X'ers and in turn them and Millennials. Common to both African American and Hispanic women is that Gen. X'ers, and particularly Millennials, both show signs of rapid income growth during their 20s and 30s. This is consistent with the closing of the gap in college enrolment rates in both populations compared to American women as a whole.

\subsection{Hours worked}

One possibility is that stagnant earnings reflect in part reductions in hours worked. This alters the comparison across generations since we normally presume that welfare is decreasing in hours worked. Figure 6 reports the number of hours usually worked per week over the life course for each generation. Looking at the plots for men in the left column we see that, consistent with existing evidence (Blundell et al., 2011, McDaniel, 2011), that there have been no abrupt changes in the number of hours worked. There is some evidence that Silent Generation high school graduates worked more on average and particularly in their 30s, and that Millennials seem to work less than Boomers and Gen. X'ers, but the overall differences are relatively small. There are, as expected, greater changes for women. With a clear increase in hours worked by all generations subsequent to the Silent Generation for all women. As well as smaller, but still noticeable, differences for college-educated women between the Boomers and Gen. X'ers (and Millennials). Figure B.4 in the Appendix provides analogous plots for African Americans and Hispanic Americans showing similar patterns. Overall, it seems reasonable to conclude that there has not been a sufficiently large decrease in hours worked by American men to imply a rising real hourly wage. 
Figure 5: Median wage by generation over the life cycle
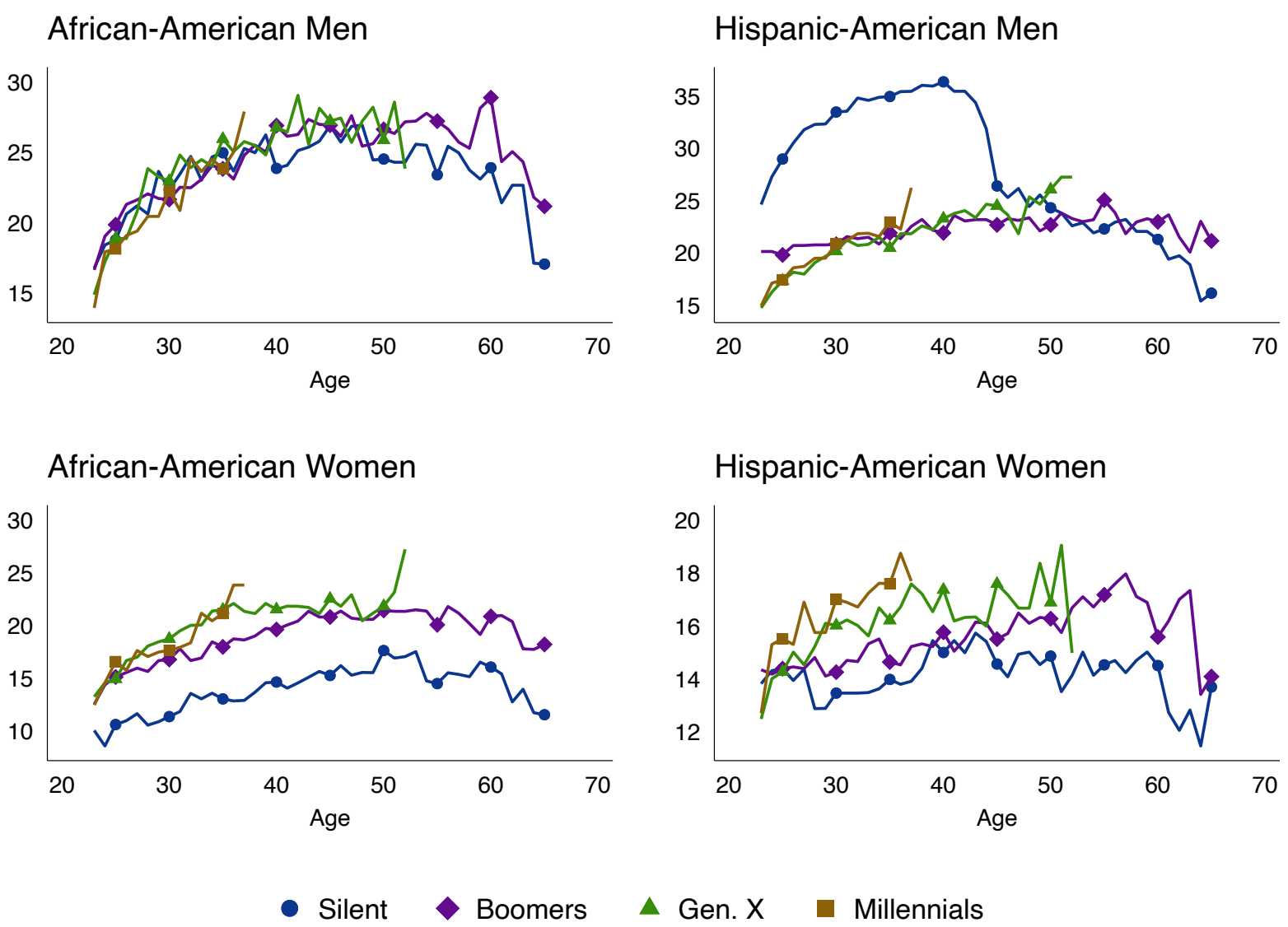

$\Delta$ Gen. X Millennials

Source: Current Population Survey (CPS)

Notes: Includes the total population, wages are adjusted for inflation, and individual weights are used. The vertical axis is median real wage in $\$ 1000$, measured in 1999 dollars.

\section{Individual level data}

The preceding graphical analysis makes clear that later generations of American men have to date suffered decreasing incomes compared to their elder peers. This is also true for female high school graduates. But, not for African American or Hispanic women or women who attended college. We now dig deeper, working with individual level data so that we can understand intergenerational differences controlling for a range of determinants.

In this section we exploit the richness of the CPS data to investigate how these patterns identified in Section 2 are related to structural change in the US economy. Specifically, whether or not there remain intergenerational differences in incomes once we allow for the changing sectoral composition of the US labour market, the changing geographical distribution of economic activity, or the increasing returns to education. ${ }^{7}$ It also means we are able to build on the recent literature documenting and explaining the decline in the labour share (Karabarbounis and Neiman, 2014, Elsby et al., 2013,

\footnotetext{
${ }^{7}$ Acemoglu and Autor (2011) provide a detailed discussion of the leading models/data.
} 
Figure 6: Weekly hours worked by generation over the life cycle
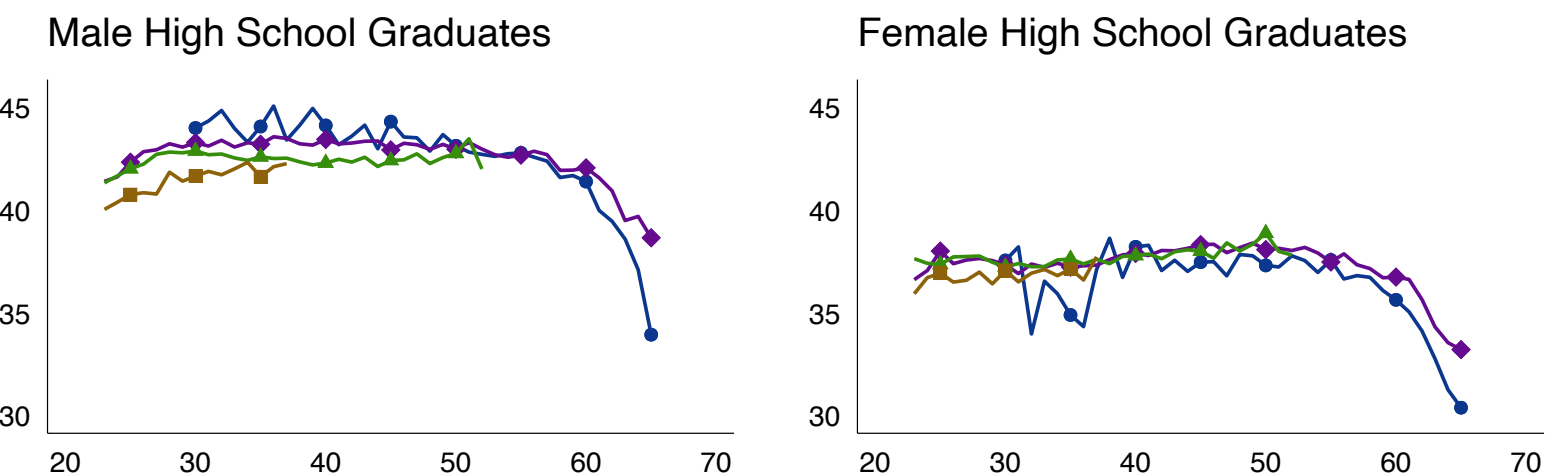

Males with College

\section{Females with College}
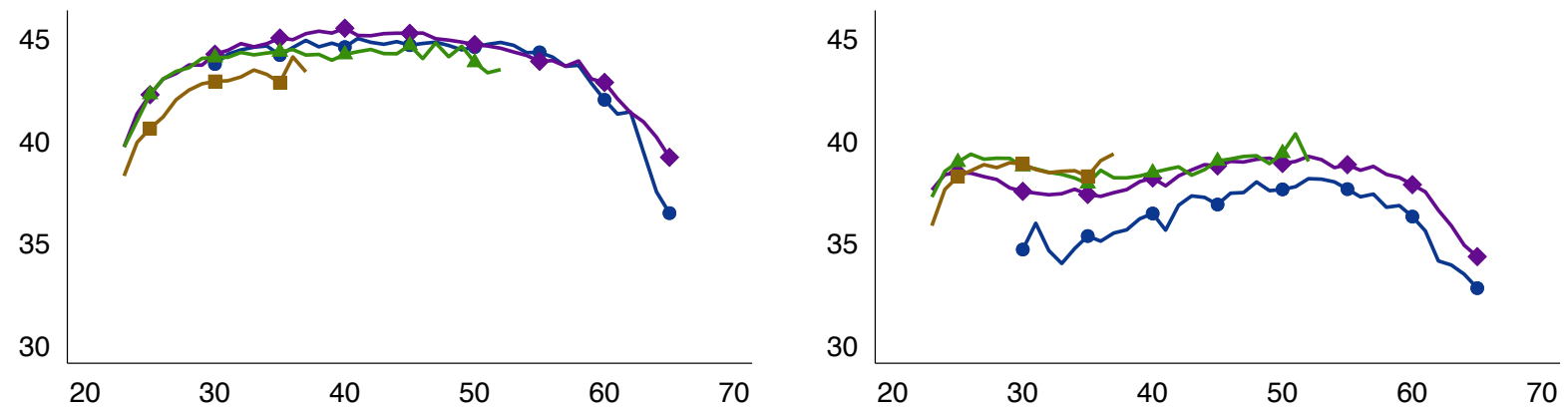

- Silent $\diamond$ Boomers $\Delta$ Gen. X $\square$ Millennials

Source: Current Population Survey (CPS)

Notes: Includes the total population and individual weights are used. 'some college' includes those who attended college and have at least a bachelor's degree. The vertical axis is median real wage in $\$ 1000$, measured in 1999 dollars. The measure of hours worked is usual hours worked per week.

Piketty, 2018, Autor et al., 2020, Grossman et al., 2018 and particularly Autor et al., 2020) to test whether, other things being equal, the decline in median lifetime earnings is, in part, due to reductions across generations in their average labour share.

This section proceeds as follows. First, we outline our measure of the labour share and then introduce our regression specification. We then present our estimates of intergenerational differences in log wages and the labour share.

\subsection{Calculating the labour share}

We compute the labour share for each generation, in each year, and in each industry. We do this using a similar approach to that of Autor et al. (2020). Like them we define the labour share of firm $k, \lambda_{k}$, as the ratio of annual payroll to the firm's total value added.

We define the labour share in industry $i$ as the size-weighted average $\lambda_{i}$, of for all firms $k$ in that industry using the data from the BEA. Linking this with data on demographic information by 
industry from the CPS means we can then compute the labour share of a given generation as the employment-weighted average of industry labour shares. We assign firms to industries on the basis of their one-digit NAICS codes. The details of how we merge the CPS data with the US Economic Census are in Appendix A. More precisely, we compute the labour share of a given generation $g$ in a given industry $i$ in a given state $s$ in a given year $t$,

Then, from the CPS we know $w_{g, i}^{s, t}$, the share of a given generation working in industry $i$ in a given year and state. Having calculated the labour share in each industry in that year and state we then compute the labour share of a generation as the share-weighted average. That is,

$$
\lambda_{g}^{s, t}=\sum_{i} \lambda_{i}^{s, t} \cdot w_{g, i}^{s, t} \quad \text { such that } \quad w_{g, i}^{s, t}=\frac{n_{g, i}^{s, t}}{N_{i}^{s, t}} \text { and } \sum_{g} w_{g, i}^{s, t}=1
$$

Where the total number of workers in industry $i$ is denoted $N_{i}$ and the number of workers in industry $i$ which belong to cohort $c$ is denoted $n_{c, i}$. We can also use variation in sectoral composition across states to compute a generation $\times$ industry $\times$ year specific labour share.

$$
\lambda_{g, i}^{t}=\sum_{s} \lambda_{i}^{s, t} w_{g, i}^{s, t}
$$

If labour markets were competitive then workers would be paid their marginal product, wages would be equal, and differences in the labour share would reflect only differences in the technology of production. ${ }^{8}$ Given labour markets are imperfectly competitive then differences in the labour share will also reflect differences in rents (Manning, 2011). Thus, intra-industry differences in the labour share received by different generations could reflect differences in the occupations of workers of different generations, and thus their marginal products, as well as differences in the rents received due to differences in bargaining power. To avoid making this assumption, we disentangle these two different effects by controlling for individuals' occupations in our regression analyses and variance decompositions. Thus, we compare the labour share of workers in a given industry by generation, holding the precise nature of their job constant. This means our assumption is now that in a given year, in a given industry, and in a given state, two workers of different generations but with the same precise occupation code have similar technologies of production.

Figure 7 plots the labour share over the life cycle by generation for each of the one-digit NAICS. Looking at the data it is clear that the Boomers have experienced consistently higher labour share at each age than any other generation. This is an interesting contrast to the previous results for income which had the Silent Generation earning more. One explanation, discussed in detail by Guvenen et al.

\footnotetext{
${ }^{8}$ Here we are implicitly assuming labour is homogeneous. The same intuition is obtained with workers of different types but wages will vary as well as the labour share in the absence of rents.
} 
(2017), is that this could reflect changes in non-pay costs such as health insurance. It could also reflect changes in the number of hours worked although the results in Section 2.2 suggest the changes have been too small to account for all of the change. Equally, it might reflect changes in the denominator and thus changes in the average, and distribution of, firms' value-added as argued by Autor et al. (2020).

Also interesting is the variation across industries, not only does the life cycle average vary considerably across industries, but the trajectories over the life cycle are also quite different. In some industries, such as Services, Finance, or Utilities and Transportation, there seems to be an initial upswing in the labour share, perhaps reflecting increased bargaining power as specific skills are obtained and labour markets become thinner. Whereas, in the Retail Trade or Manufacturing, the labour share consistently drops over the life cycle.

Figure 7: Labour share by age for each industry and generation
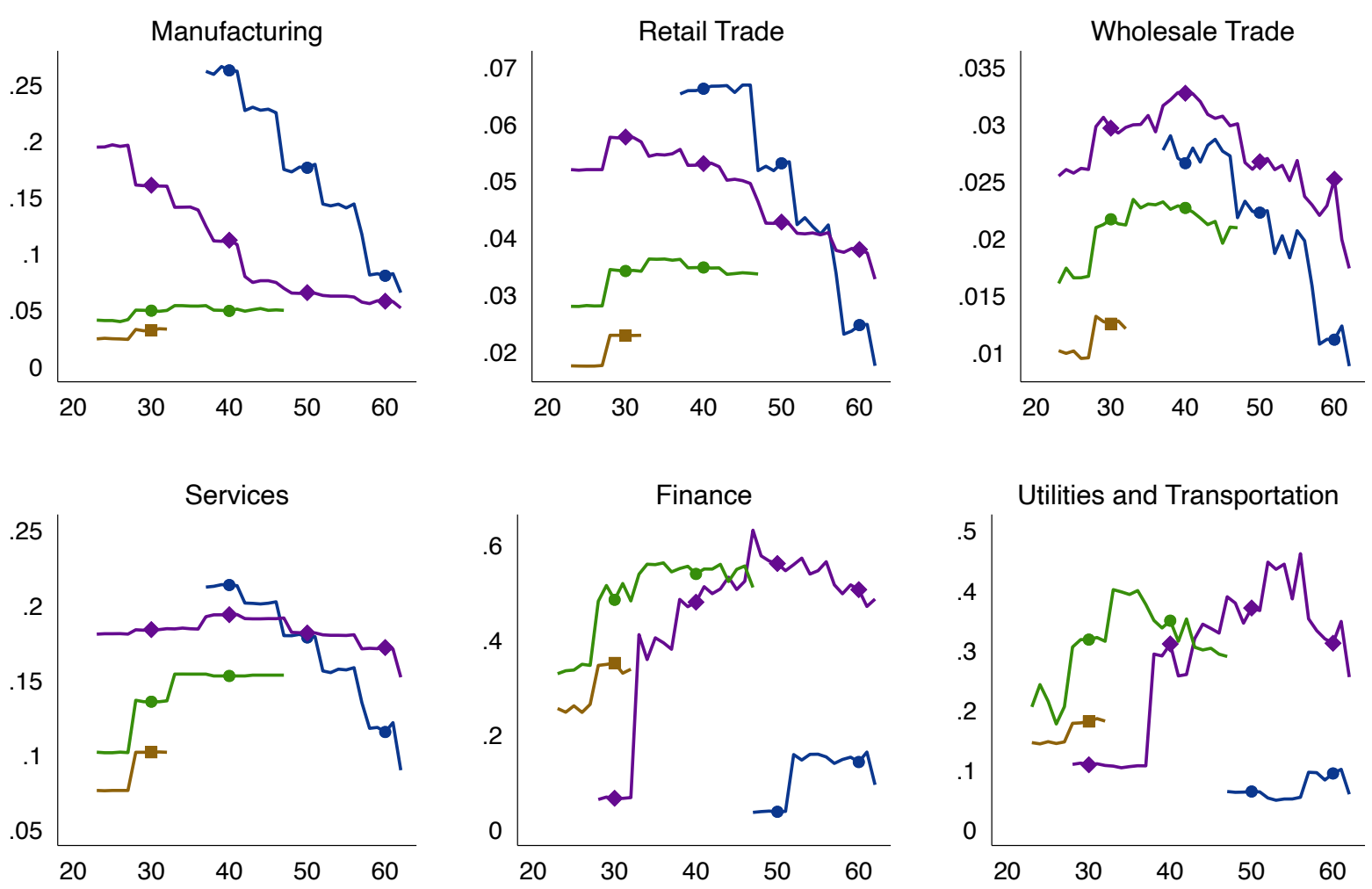

- Silent B Boomers $\Delta$ Gen. X Millennials

Source: US Economics Census \& Current Population Survey (CPS)

Notes: Data is merged at the year, state and one-digit industry level as described in Appendix A. The labour share is calculated as described in Section 3.1. Individual weights provided by the CPS are used. 


\subsection{Regression analysis}

We work with the following specification where $c_{j, t}$ is either $(\log )$ wages or the labour share of individual $j$ in a given year.

$$
c_{j, t}^{i}=\gamma_{g}^{i}+X_{j, t}^{\prime} \beta^{i}+\delta_{s}^{i}+\varepsilon_{j, t}^{i}
$$

We estimate this equation separately for each industry $i$ so that we allow both the structure of earnings differences across generations to vary by industry. To allow for these changes in the sectoral and geographic composition of the US economy as well as the changing role of education and demographic characteristics means that we will estimate separate specifications for each industry. At the cost of additional coefficients to consider, this allows for unrestricted heterogeneity across specifications as well as ease of interpretation. It will also highlight important sources of heterogeneity. This also means that we allow the effects of both observables, such as age, education, or race, and the fixed effects to vary across industries in an unrestricted way. This is important since, for example, there is good to reason to believe that the return to education may differ by sector. Moreover, as discussed above, both theory and prior empirical evidence suggests that we should expect heterogeneity across sectors due both to the potential for automation and the adoption of computers (Acemoglu and Restrepo, 2018, Autor and Salomons, 2018, Burstein et al., 2019) as well as the differential effects of offshoring and sector specific productivity trends (Elsby et al., 2013, Grossman et al., 2018).

We are most interested in the vector of generational dummies $\gamma_{g}^{i}$, which capture how the average earnings of each generation differ (with respect to the Silent Generation). $\beta^{i}$ captures the effects of a standard set of educational and demographic controls (and occupation controls in later specifications). Specifically, we include a quadratic in age, dummies for being African American or Hispanic as well as Female and whether the respondent graduated high school or attended college, moreover we include a number of occupation controls to capture the impact of changing technologies and the value of human capital. We can also include state fixed effects, $\delta_{s}^{i}$, to capture persistent differences in local labour markets..$^{9}$

To build our intuition, Table 2 presents regressions of differing specification by industry. Panel A refers to a minimal specification in which we omit the controls and the fixed effects from Equation (3). Looking across the first row we can see that Boomers have, unconditionally, earned more in Retail, Services, Finance and Utilities, yet less in Construction and Manufacturing compared with the Silent Generation. Wages in Mining and Wholesale Trade have remained about the same with changes which

\footnotetext{
${ }^{9}$ Given how we construct our data, we do not have sufficient variation to include year fixed effects as well as our age and generation controls. Thus, the age coefficients will reflect both age related effects such as human capital accumulation or seniority, and the average shock experienced by members of that generation at that age. Given our focus on cohorts, this does not overly affect our inference.
} 
Table 2: Generational differences in real wages by industry

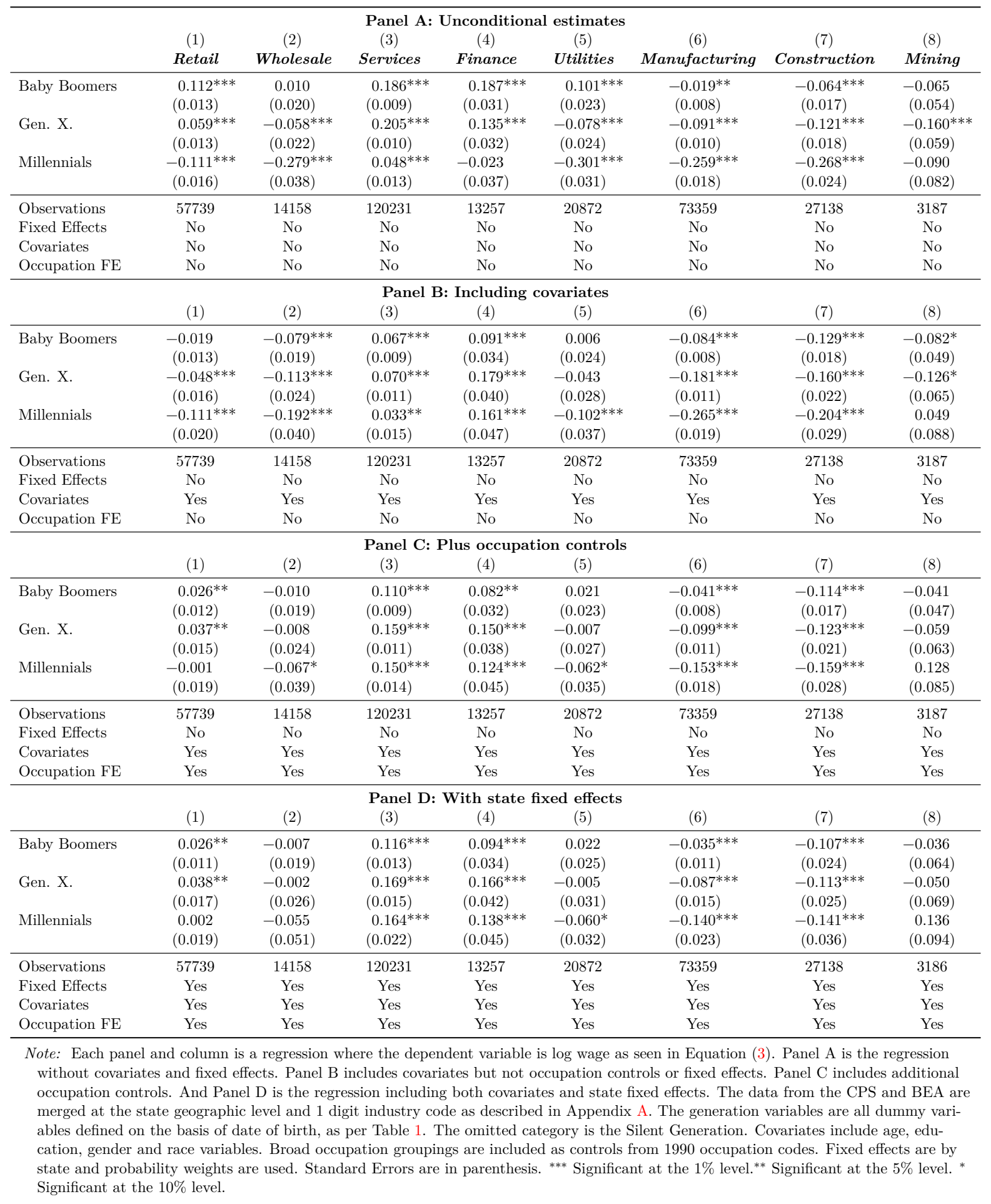


are not statistically significant. Finance sees the biggest increase, where wages were $20.56 \%$ higher, ${ }^{10}$ followed by services with $20.44 \%$, then we see retail and utilities with earnings which are $11.85 \%$ and $10.6 \%$, respectively compared to the silent generation. Note that these are large differences and imply substantial differences in lifetime consumption levels. Looking now at the second row of Panel A, we note that, again, Retail, Services and Finance have positive coefficients and that all other sectors are associated with a reduction in the average wage or evidence of no change in average wage. Moreover we see an increase in the magnitude for Service, with wages which are on average $22.75 \%$ higher. There are slightly lower magnitudes for Retail and Finance as for the Baby Boomer generation. However the Gen. X'ers working in Manufacturing and Construction are earning on average $9.5 \%$ and $12.86 \%$ less than their Silent Generation counterparts, respectively. When we look at the results for Millennials in the third row, we see coefficients are smaller or turn negative. Millennials are seeing on average their earnings lower than their counterparts in the Silent Generation if working in Wholesale, Utilities, Manufacturing and Construction. Services and Finance workers have earnings which are on average $5 \%$ and $2.3 \%$ higher than the equivalent Silent Generation workers, however the result if not statistically significant for the finance industry.

Of course, one explanation for these changes is that the average worker in sectors such as Finance has changed over time. Thus, increased earnings in Finance may reflect declining numbers of accounting clerks compared to investment bankers or financial advisers. The additional panels in Table 2, introduce demographic controls, occupation controls and state fixed effects, such that the intergenerational comparison is now a more precise one. Turning firstly to Panel B, where we introduce individual covariates such as age, race, gender and education dummies, ${ }^{11}$ we find statistically significant coefficients for all industries apart from Mining for Millennials. Finance and Services are notable outliers, where conditional on individual characteristics, they earn $16.47 \%$ and around $3.3 \%$ more on average compared to the Silent Generation. Others Millennial workers earn between $11 \%$ and $30 \%$ less than counterpart Silent Generation workers controlling for age, gender, race and education. That finance seems to be an outlier, is consistent with the evidence of a substantial wage premium for those working in Finance, both in the US (Philippon and Reshef, 2012) and internationally (Philippon and Reshef, 2013). This premium around 50\% for the US and they find can only be partly explained by increases in earnings risk.

To make the comparison more precise, Panel $\mathrm{C}$ of Table 2 reports results adding occupation controls and Panel D adds state fixed effects such that the comparison is within industry, occupation, state,

\footnotetext{
${ }^{10}$ Given the regressors are dummies, we can not interpret the changes directly in percentage terms, instead we calculate $20.56 \%=100 *(\exp (0.187)-1)$.

${ }^{11}$ The full list of covariates used can be found in Appendix B.1, where we include the full regression tables.
} 
Table 3: Generational differences in wage and labour share: pooled estimates

\begin{tabular}{|c|c|c|c|c|c|c|c|c|}
\hline & $\begin{array}{l}(1) \\
\text { Wage }\end{array}$ & $\begin{array}{l}(2) \\
\text { Wage }\end{array}$ & $\begin{array}{c}(3) \\
\text { Wage }\end{array}$ & $\begin{array}{l}\text { anel A } \\
(4) \\
\text { Wage }\end{array}$ & $\begin{array}{c}(5) \\
\text { Labour Share }\end{array}$ & $\begin{array}{c}(6) \\
\text { Labour Share }\end{array}$ & $\begin{array}{c}(7) \\
\text { Labour Share }\end{array}$ & $\begin{array}{c}(8) \\
\text { Labour Share }\end{array}$ \\
\hline Baby Boomers & $\begin{array}{l}0.080^{* * *} \\
(0.005)\end{array}$ & $\begin{array}{l}-0.019^{* * *} \\
(0.005)\end{array}$ & $\begin{array}{l}-0.016^{* * *} \\
(0.005)\end{array}$ & $\begin{array}{l}0.025^{* * *} \\
(0.005)\end{array}$ & $\begin{array}{l}0.002^{* * *} \\
(0.001)\end{array}$ & $\begin{array}{l}0.003^{* * *} \\
(0.001)\end{array}$ & $\begin{array}{c}-0.006^{* * *} \\
(0.000)\end{array}$ & $\begin{array}{c}-0.006^{* * *} \\
(0.000)\end{array}$ \\
\hline Gen. X. & $\begin{array}{l}0.015^{* * *} \\
(0.005)\end{array}$ & $\begin{array}{c}-0.065^{* * *} \\
(0.006)\end{array}$ & $\begin{array}{c}-0.043^{* * *} \\
(0.006)\end{array}$ & $\begin{array}{l}0.033^{* * *} \\
(0.006)\end{array}$ & $\begin{array}{l}0.004^{* * *} \\
(0.001)\end{array}$ & $\begin{array}{l}0.007^{* * *} \\
(0.001)\end{array}$ & $\begin{array}{l}-0.008^{* * *} \\
(0.001)\end{array}$ & $\begin{array}{l}-0.007^{* * *} \\
(0.001)\end{array}$ \\
\hline Millennials & $\begin{array}{l}-0.182^{* * *} \\
(0.008)\end{array}$ & $\begin{array}{l}-0.129^{* * * *} \\
(0.009)\end{array}$ & $\begin{array}{l}-0.087^{* * * *} \\
(0.009)\end{array}$ & $\begin{array}{c}0.011 \\
(0.008)\end{array}$ & $\begin{array}{l}0.002^{* *} \\
(0.001)\end{array}$ & $\begin{array}{l}0.007^{* * * *} \\
(0.001)\end{array}$ & $\begin{array}{l}-0.009^{* * *} \\
(0.001)\end{array}$ & $\begin{array}{l}-0.008^{* * *} \\
(0.001)\end{array}$ \\
\hline $\begin{array}{l}\text { Observations } \\
\text { Individual Con. } \\
\text { Industry Controls } \\
\text { Occupation FE } \\
\text { State FE }\end{array}$ & $\begin{array}{l}329941 \\
\text { No } \\
\text { No } \\
\text { No } \\
\text { No }\end{array}$ & $\begin{array}{l}329941 \\
\text { Yes } \\
\text { No } \\
\text { No } \\
\text { No }\end{array}$ & $\begin{array}{l}329941 \\
\text { Yes } \\
\text { Yes } \\
\text { No } \\
\text { No }\end{array}$ & $\begin{array}{l}329941 \\
\text { Yes } \\
\text { Yes } \\
\text { Yes } \\
\text { No }\end{array}$ & $\begin{array}{l}329726 \\
\text { No } \\
\text { No } \\
\text { No } \\
\text { No }\end{array}$ & $\begin{array}{l}329726 \\
\text { Yes } \\
\text { No } \\
\text { No } \\
\text { No }\end{array}$ & $\begin{array}{l}329726 \\
\text { Yes } \\
\text { Yes } \\
\text { No } \\
\text { No }\end{array}$ & $\begin{array}{l}329726 \\
\text { Yes } \\
\text { Yes } \\
\text { Yes } \\
\text { No }\end{array}$ \\
\hline & $\begin{array}{c}(1) \\
\text { Wage }\end{array}$ & $\begin{array}{c}(2) \\
\text { Wage }\end{array}$ & $\begin{array}{l}\text { Panel B: } \\
(3) \\
\text { Wage }\end{array}$ & $\begin{array}{l}\text { state fixe } \\
(4) \\
\text { Wage }\end{array}$ & $\begin{array}{l}\text { effects } \\
\qquad(5) \\
\text { Labour Share }\end{array}$ & $\begin{array}{c}(6) \\
\text { Labour Share }\end{array}$ & $\begin{array}{c}(7) \\
\text { Labour Share }\end{array}$ & $\begin{array}{c}(8) \\
\text { Labour Share }\end{array}$ \\
\hline Baby Boomers & $\begin{array}{l}0.081^{* * *} \\
(0.009)\end{array}$ & $\begin{array}{c}-0.013 \\
(0.008)\end{array}$ & $\begin{array}{c}-0.009 \\
(0.007)\end{array}$ & $\begin{array}{l}0.030^{* * *} \\
(0.007)\end{array}$ & $\begin{array}{l}0.003^{* *} \\
(0.001)\end{array}$ & $\begin{array}{l}0.004^{* * * *} \\
(0.001)\end{array}$ & $\begin{array}{c}-0.006^{* * *} \\
(0.001)\end{array}$ & $\begin{array}{c}-0.005^{* * *} \\
(0.001)\end{array}$ \\
\hline Gen. X. & $\begin{array}{c}0.015 \\
(0.014)\end{array}$ & $\begin{array}{c}-0.054^{* * *} \\
(0.012)\end{array}$ & $\begin{array}{l}-0.031^{* * *} \\
(0.011)\end{array}$ & $\begin{array}{l}0.042^{\text {*** }} \\
(0.010)\end{array}$ & $\begin{array}{l}0.005^{* *} \\
(0.002)\end{array}$ & $\begin{array}{l}0.008^{* * * *} \\
(0.003)\end{array}$ & $\begin{array}{l}-0.007^{\text {*** }} \\
(0.002)\end{array}$ & $\begin{array}{l}-0.007^{* * *} \\
(0.002)\end{array}$ \\
\hline Millennials & $\begin{array}{c}-0.180^{* * *} \\
(0.017)\end{array}$ & $\begin{array}{l}-0.114^{* * *} \\
(0.018)\end{array}$ & $\begin{array}{l}-0.071^{* * *} \\
(0.016)\end{array}$ & $\begin{array}{c}0.024 \\
(0.015)\end{array}$ & $\begin{array}{c}0.003 \\
(0.002)\end{array}$ & $\begin{array}{l}0.008^{* *} \\
(0.003)\end{array}$ & $\begin{array}{c}-0.008^{* *} \\
(0.003)\end{array}$ & $\begin{array}{c}-0.007^{* *} \\
(0.003)\end{array}$ \\
\hline Observations & 329941 & 329941 & 329941 & 329941 & 329726 & 329726 & 329726 & 329726 \\
\hline Individual Con. & No & Yes & Yes & Yes & No & Yes & Yes & Yes \\
\hline Industry Controls & No & No & Yes & Yes & No & No & Yes & Yes \\
\hline Occupation FE & No & No & No & Yes & No & No & No & Yes \\
\hline State FE & Yes & Yes & Yes & Yes & Yes & Yes & Yes & Yes \\
\hline
\end{tabular}

Note: Each panel and column is a regression where the dependent variable is real wage for Columns (1) to (4) and labour share in Columns (5) to (8) as seen in Equation (3) but pooling across industries. Panel A is the regression without fixed effects. Panel B includes state fixed effects. The data from the CPS and BEA are merged at the state geographic level and one-digit industry code as described in Appendix A. Generation is defined on the basis of date of birth, as per Table 1. Covariates include variables for age, race, gender and education, plus additional occupation controls. Probability weights are used. Standard Errors are in parenthesis. ${ }^{* * *}$ Significant at the $1 \%$ level.** Significant at the $5 \%$ level. ${ }^{*}$ Significant at the $10 \%$ level.

and year. The overall pattern of results is unchanged. Again, we obtain positive and precise estimates for the services and finance sectors. Wages in services are $12.3 \%$ and $17.8 \%$ higher for Boomers and Millennials relative to the Silent generation, respectively. Whilst in finance this is now $9.9 \%$ and $14.8 \%$, respectively. Meanwhile, large, statistically significant, declines in real wages can be seen for recent generations in Manufacturing and Construction industries; with Millennial workers earning $13 \%$ less than the silent generation in the Construction industry.

To understand the aggregate differences between generations we pool across industries and estimate Equation (3) for the economy as a whole. The results are reported in Columns 1-4 of Table 3. These results suggest that overall Boomers' wages have been higher than those of the Silent Generation with Millennials having lower wages both conditionally and unconditionally than the three preceding generations.

Taken together, our analysis of the individual level data suggest that even controlling for changes in the composition of the workforce and state fixed effects, we still find a downwards trend in real median earnings from the Silent Generation and the Boomers to the Millennials. We now consider why this might be the case. 
Table 4: Determinants of real wages: generation specific estimates

\begin{tabular}{|c|c|c|c|c|c|c|c|c|}
\hline & $\begin{array}{c}(1) \\
\text { Silent }\end{array}$ & $\begin{array}{c}(2) \\
\text { Boomers }\end{array}$ & $\begin{array}{c}(3) \\
\text { Gen. } X\end{array}$ & $\begin{array}{c}\text { Panel A } \\
(4) \\
\text { Millenials }\end{array}$ & $\begin{array}{c}(5) \\
\text { Silent }\end{array}$ & $\begin{array}{c}(6) \\
\text { Boomers }\end{array}$ & $\begin{array}{c}(7) \\
\text { Gen. } X\end{array}$ & $\begin{array}{c}(8) \\
\text { Millenials }\end{array}$ \\
\hline Age & $\begin{array}{l}0.109^{* * *} \\
(0.006)\end{array}$ & $\begin{array}{l}0.057^{* * *} \\
(0.002)\end{array}$ & $\begin{array}{l}0.145^{* * *} \\
(0.005)\end{array}$ & $\begin{array}{l}0.415^{* * *} \\
(0.044)\end{array}$ & $\begin{array}{l}0.077^{* * *} \\
(0.006)\end{array}$ & $\begin{array}{l}0.050^{* * *} \\
(0.002)\end{array}$ & $\begin{array}{l}0.141^{* * *} \\
(0.005)\end{array}$ & $\begin{array}{l}0.375^{* * *} \\
(0.043)\end{array}$ \\
\hline Age Sq & $\begin{array}{c}-0.001^{* * *} \\
(0.000)\end{array}$ & $\begin{array}{c}-0.001^{* * *} \\
(0.000)\end{array}$ & $\begin{array}{c}-0.002^{* * *} \\
(0.000)\end{array}$ & $\begin{array}{c}-0.007^{* * *} \\
(0.001)\end{array}$ & $\begin{array}{c}-0.001^{* * *} \\
(0.000)\end{array}$ & $\begin{array}{c}-0.001^{* * *} \\
(0.000)\end{array}$ & $\begin{array}{c}-0.002^{* * *} \\
(0.000)\end{array}$ & $\begin{array}{c}-0.006^{* * *} \\
(0.001)\end{array}$ \\
\hline African American & $\begin{array}{c}-0.204^{* * *} \\
(0.013)\end{array}$ & $\begin{array}{c}-0.214^{* * *} \\
(0.008)\end{array}$ & $\begin{array}{c}-0.172^{* * *} \\
(0.009)\end{array}$ & $\begin{array}{c}-0.189^{* * *} \\
(0.019)\end{array}$ & $\begin{array}{c}-0.200^{* * *} \\
(0.013)\end{array}$ & $\begin{array}{c}-0.218^{* * *} \\
(0.007)\end{array}$ & $\begin{array}{c}-0.172^{* * *} \\
(0.009)\end{array}$ & $\begin{array}{l}-0.185^{* * *} \\
(0.019)\end{array}$ \\
\hline Hispanic & $\begin{array}{c}-0.223^{* * *} \\
(0.013)\end{array}$ & $\begin{array}{c}-0.222^{\text {**** }} \\
(0.007)\end{array}$ & $\begin{array}{c}-0.136^{* * *} \\
(0.007)\end{array}$ & $\begin{array}{c}-0.085^{* * *} \\
(0.014)\end{array}$ & $\begin{array}{l}-0.222^{* * *} \\
(0.013)\end{array}$ & $\begin{array}{l}-0.214^{* * *} \\
(0.007)\end{array}$ & $\begin{array}{c}-0.134^{* * *} \\
(0.007)\end{array}$ & $\begin{array}{c}-0.088^{* * *} \\
(0.014)\end{array}$ \\
\hline $\begin{array}{l}\text { High School } \\
\text { Graduate }\end{array}$ & $\begin{array}{l}0.279^{* * *} \\
(0.008)\end{array}$ & $\begin{array}{l}0.283^{* * *} \\
(0.006)\end{array}$ & $\begin{array}{l}0.386^{* * *} \\
(0.010)\end{array}$ & $\begin{array}{l}0.367^{* * *} \\
(0.020)\end{array}$ & $0.291^{* * *}$ & $0.294^{* * *}$ & $0.377^{* * *}$ & $0.363^{* * *}$ \\
\hline College & $\begin{array}{l}0.424^{* * *} \\
(0.014)\end{array}$ & $\begin{array}{l}0.511^{* * * *} \\
(0.006)\end{array}$ & $\begin{array}{l}0.550^{* * *} \\
(0.007)\end{array}$ & $\begin{array}{l}0.495^{* * *} \\
(0.013)\end{array}$ & $\begin{array}{l}0.444^{* * *} \\
(0.014)\end{array}$ & $\begin{array}{l}0.508^{* * *} \\
(0.006)\end{array}$ & $\begin{array}{l}0.534^{* * *} \\
(0.007)\end{array}$ & $\begin{array}{l}0.477^{* * *} \\
(0.013)\end{array}$ \\
\hline Female & $\begin{array}{l}-0.708^{* * *} \\
(0.008)\end{array}$ & $\begin{array}{c}-0.502^{* * * *} \\
(0.004)\end{array}$ & $\begin{array}{c}-0.407^{* * *} \\
(0.006)\end{array}$ & $\begin{array}{c}-0.265^{* * *} \\
(0.011)\end{array}$ & $\begin{array}{l}-0.614^{* * *} \\
(0.008)\end{array}$ & $\begin{array}{l}-0.451^{* * *} \\
(0.005)\end{array}$ & $\begin{array}{l}-0.372^{* * *} \\
(0.006)\end{array}$ & $\begin{array}{c}-0.217^{* * *} \\
(0.012)\end{array}$ \\
\hline Observations & 51908 & 160577 & 94243 & 23213 & 51908 & 160577 & 94243 & 23213 \\
\hline Industry Controls & No & No & No & No & Yes & Yes & Yes & Yes \\
\hline Occupation FE & No & No & No & No & No & No & No & No \\
\hline State FE & No & No & No & No & No & No & No & No \\
\hline & (1) & (2) & (3) & $\begin{array}{c}\text { Panel B } \\
(4)\end{array}$ & $(5)$ & (6) & (7) & (8) \\
\hline Age & $\begin{array}{l}0.074^{* * *} \\
(0.005)\end{array}$ & $\begin{array}{l}0.055^{* * *} \\
(0.002)\end{array}$ & $\begin{array}{l}0.131^{* * *} \\
(0.004)\end{array}$ & $\begin{array}{l}0.375^{* * *} \\
(0.041)\end{array}$ & $\begin{array}{l}0.074^{* * *} \\
(0.008)\end{array}$ & $\begin{array}{l}0.055^{* * *} \\
(0.002)\end{array}$ & $\begin{array}{l}0.131^{* * *} \\
(0.003)\end{array}$ & $\begin{array}{l}0.371^{* * *} \\
(0.037)\end{array}$ \\
\hline Age Sq & $\begin{array}{l}-0.001^{* * *} \\
(0.000)\end{array}$ & $\begin{array}{c}-0.001^{* * *} \\
(0.000)\end{array}$ & $\begin{array}{c}-0.002^{* * *} \\
(0.000)\end{array}$ & $\begin{array}{c}-0.006^{* * *} \\
(0.001)\end{array}$ & $\begin{array}{l}-0.001^{* * *} \\
(0.000)\end{array}$ & $\begin{array}{c}-0.001^{* * *} \\
(0.000)\end{array}$ & $\begin{array}{c}-0.002^{* * *} \\
(0.000)\end{array}$ & $\begin{array}{c}-0.006^{* * *} \\
(0.001)\end{array}$ \\
\hline African American & $\begin{array}{c}-0.074^{* * *} \\
(0.013)\end{array}$ & $\begin{array}{c}-0.125^{* * *} \\
(0.007)\end{array}$ & $\begin{array}{c}-0.117^{* * *} \\
(0.009)\end{array}$ & $\begin{array}{c}-0.150^{* * *} \\
(0.018)\end{array}$ & $\begin{array}{c}-0.078^{* * *} \\
(0.020)\end{array}$ & $\begin{array}{c}-0.125^{* * *} \\
(0.010)\end{array}$ & $\begin{array}{c}-0.126^{* * *} \\
(0.009)\end{array}$ & $\begin{array}{c}-0.156^{* * *} \\
(0.016)\end{array}$ \\
\hline Hispanic & $\begin{array}{c}-0.129^{* * *} \\
(0.013)\end{array}$ & $\begin{array}{c}-0.136^{* * *} \\
(0.006)\end{array}$ & $\begin{array}{c}-0.087^{* * *} \\
(0.007)\end{array}$ & $\begin{array}{c}-0.069^{* * *} \\
(0.013)\end{array}$ & $\begin{array}{c}-0.157^{* * *} \\
(0.023)\end{array}$ & $\begin{array}{c}-0.168^{* * * *} \\
(0.014)\end{array}$ & $\begin{array}{l}-0.116^{* * *} \\
(0.013)\end{array}$ & $\begin{array}{c}-0.099^{* * *} \\
(0.024)\end{array}$ \\
\hline $\begin{array}{l}\text { High School } \\
\text { Graduate }\end{array}$ & $\begin{array}{l}0.139^{* * *} \\
(0.008)\end{array}$ & $\begin{array}{l}0.162^{\text {*** }} \\
(0.006)\end{array}$ & $\begin{array}{l}0.278^{* * *} \\
(0.010)\end{array}$ & $\begin{array}{l}0.300^{* * *} \\
(0.020)\end{array}$ & $\begin{array}{l}0.135^{* * *} \\
(0.011)\end{array}$ & $\begin{array}{l}0.159^{* * *} \\
(0.009)\end{array}$ & $\begin{array}{l}0.280^{* * *} \\
(0.011)\end{array}$ & $\begin{array}{l}0.300^{* * *} \\
(0.016)\end{array}$ \\
\hline College & $\begin{array}{l}0.233^{* * *} \\
(0.014)\end{array}$ & $\begin{array}{l}0.289^{* * *} \\
(0.006)\end{array}$ & $\begin{array}{l}0.333^{* * *} \\
(0.007)\end{array}$ & $\begin{array}{l}0.326^{* * *} \\
(0.014)\end{array}$ & $\begin{array}{l}0.224^{* * *} \\
(0.016)\end{array}$ & $\begin{array}{l}0.280^{* * *} \\
(0.007)\end{array}$ & $\begin{array}{l}0.323^{* * *} \\
(0.009)\end{array}$ & $\begin{array}{l}0.318^{* * *} \\
(0.021)\end{array}$ \\
\hline Female & $\begin{array}{l}-0.592^{* * *} \\
(0.009)\end{array}$ & $\begin{array}{c}-0.465^{* * *} \\
(0.005)\end{array}$ & $\begin{array}{c}-0.394^{* * *} \\
(0.006)\end{array}$ & $\begin{array}{c}-0.223^{* * *} \\
(0.012)\end{array}$ & $\begin{array}{c}-0.588^{* * *} \\
(0.011)\end{array}$ & $\begin{array}{c}-0.462^{* * *} \\
(0.008)\end{array}$ & $\begin{array}{l}-0.391^{* * *} \\
(0.011)\end{array}$ & $\begin{array}{c}-0.221^{* * *} \\
(0.012)\end{array}$ \\
\hline Observations & 51908 & 160577 & 94243 & 23213 & 51908 & 160577 & 94243 & 23213 \\
\hline Industry Controls & Yes & Yes & Yes & Yes & Yes & Yes & Yes & Yes \\
\hline Occupation FE & Yes & Yes & Yes & Yes & Yes & Yes & Yes & Yes \\
\hline State FE & No & No & No & No & Yes & Yes & Yes & Yes \\
\hline
\end{tabular}

Note: Each panel and column is a regression where the dependent variable is real wage as seen in Equation (3) but pooling across industries and disaggregating instead by generation. Panel A is the regression without any fixed effects, columns (1) to (4) of panel A does not include industry controls whereas Columns (5) to (8) do. Panel B includes fixed effects in columns (5) to (8) only and columns (1) to (4) include additional occupation controls. The data from the CPS and BEA are merged at the state geographic level and one-digit industry code as described in Appendix A. Generation is defined on the basis of date of birth, as per Table 1. Fixed effects are by state and probability weights are used. Standard errors are in parenthesis. ${ }^{* *}$ Significant at the $1 \%$ level.** Significant at the $5 \%$ level. * Significant at the $10 \%$ level.

\subsection{Explanations}

Table 4 reports the results of an analogous specification to Equation (3) except that now we disaggregate by generation and pool over industries. This allows us to get a sense of the differences in the the effects of observables across generations. We begin by considering the effects of education and age (as our proxy for experience). Looking first at age we can see that the coefficients on Age and Age Squared are reasonably consistent across the Silent Generation and Gen. X and then starkly different for Millennials.

Perhaps most interesting is that the positive impact of education on wages first grew, as the literature on skills-biased technological change documents (Acemoglu and Autor, 2011), but has fallen for Millennials with the returns to college attendance lower for Millennials than for Boomer's in specifications which include additional industry controls and fixed effects. The return to high school 
graduation is also lower than that for Gen. X'ers. It is important not to over-interpret a single specification given the substantial literature employing much richer specifications which document the increasing demand for college graduates and increasing returns to education (Acemoglu and Autor, 2011). Our interpretation of these results is that, very broadly, while the college wage premium has increased across previous generations that it now seems to be falling for Millennials, perhaps limiting wage growth despite growing college attendance rates.

Thus, it is hard to explain the intergenerational decline in median earnings with an appeal to the changing returns to human capital. It does not seem to be the case that later generations have earned much larger returns to education. The other key change in the labour market in the period has been increased participation by women. This is born out by the reduction in the magnitude of the female coefficient which is around $19.8 \%$ for Millennials down from $44.5 \%$ for the Silent Generation (given the full specification in columns (5)-(8) of Panel B). That is, there continues to be a substantial gender pay gap between Millennials, but it is significantly smaller than that of previous generations. This is as expected given the findings of the large literature on the US gender pay gap (Goldin, 2014). But, as an explanation for the intergenerational decline in median wages it is most useful to consider it in light of the analysis of Guvenen et al. (2017). Recall, that their analysis shows that while women's share of cohort lifetime earnings nearly doubles across the 27 cohorts they study that much of this increase is due to increased labour force attachment and that median women's earnings have grown slowly and remain at a substantially lower level than those of men. Similarly, there is limited evidence of substantial intergenerational changes in racial earnings inequality. Looking at Panel A, we see that there appears to be little improvement in the earnings gap between the Silent Generation and the Millennials, with coefficients of $18 \%$ and $16 \%$, respectfully. Once we include occupation controls in Panel B, there is a suggestion that the earnings gap is growing, with coefficients now $-7.5 \%$ for the Silent Generation and $-14 \%$ for Millennials in the full specification. ${ }^{12}$ On the other hand, the gap for Hispanic Americans has reduced markedly - from just over $14 \%$ for the Silent Generation to around 9\% for Millennials looking at the full specification.

It seems then that, notwithstanding the decline in the Hispanic earnings gap and increased female labour force participation, the correlates of earnings have been broadly consistent from one generation to the next. Thus, understanding the decline in median wages requires another explanation. To this end, we now consider the role of the labour share.

\footnotetext{
${ }^{12}$ Lang and Manove (2011) show that the racial earnings gap is increased when a richer set of educational controls are included. Fryer (2011) shows that there is good reason to believe that it has declined for those born more recently.
} 
Table 5: Generational differences in labour share by industry

\begin{tabular}{|c|c|c|c|c|c|c|c|c|}
\hline & $\begin{array}{c}(1) \\
\text { Retail }\end{array}$ & $\begin{array}{c}(2) \\
\text { Wholesale }\end{array}$ & $\begin{array}{c}\text { Panel A: } \\
(3) \\
\text { Services }\end{array}$ & $\begin{array}{c}\text { ncondition } \\
\text { (4) } \\
\text { Finance }\end{array}$ & $\begin{array}{c}\text { estimates } \\
(5) \\
\text { Utilities }\end{array}$ & $\begin{array}{c}(6) \\
\text { Manufacturing }\end{array}$ & $\begin{array}{c}(7) \\
\text { Construction }\end{array}$ & $\begin{array}{c}(8) \\
\text { Mining }\end{array}$ \\
\hline Baby Boomers & $\begin{array}{c}-0.004^{* * * *} \\
(0.000)\end{array}$ & $\begin{array}{l}0.000^{* * *} \\
(0.000)\end{array}$ & $\begin{array}{l}0.002^{* * *} \\
(0.000)\end{array}$ & $\begin{array}{l}0.074^{* * *} \\
(0.008)\end{array}$ & $\begin{array}{l}0.059^{* * *} \\
(0.008)\end{array}$ & $\begin{array}{l}-0.033^{* * *} \\
(0.001)\end{array}$ & $\begin{array}{l}-0.008^{* * *} \\
(0.000)\end{array}$ & $\begin{array}{l}-0.012^{* * *} \\
(0.004)\end{array}$ \\
\hline Gen. X. & $\begin{array}{l}-0.007^{* * *} \\
(0.000)\end{array}$ & $\begin{array}{c}0.000 \\
(0.000)\end{array}$ & $\begin{array}{l}0.003^{* * *} \\
(0.000)\end{array}$ & $\begin{array}{l}0.119^{* * *} \\
(0.008)\end{array}$ & $\begin{array}{l}0.110^{* * *} \\
(0.009)\end{array}$ & $\begin{array}{l}-0.068^{* * *} \\
(0.000)\end{array}$ & $\begin{array}{l}-0.017^{* * *} \\
(0.000)\end{array}$ & $\begin{array}{l}-0.035^{* * *} \\
(0.004)\end{array}$ \\
\hline Millennials & $\begin{array}{l}-0.010^{* * *} \\
(0.000)\end{array}$ & $\begin{array}{l}-0.002^{* * *} \\
(0.000)\end{array}$ & $\begin{array}{l}0.004^{* * *} \\
(0.000)\end{array}$ & $\begin{array}{l}0.149^{* * *} \\
(0.009)\end{array}$ & $\begin{array}{l}0.099^{* * *} \\
(0.008)\end{array}$ & $\begin{array}{l}-0.076^{* * *} \\
(0.000)\end{array}$ & $\begin{array}{l}-0.022^{* * *} \\
(0.000)\end{array}$ & $\begin{array}{l}-0.044^{* * *} \\
(0.004)\end{array}$ \\
\hline Observations & 57739 & 14158 & 120231 & 13102 & 20827 & 73359 & 27138 & 3172 \\
\hline Fixed Effects & No & No & No & No & No & No & No & No \\
\hline Covariates & No & No & No & No & No & No & No & No \\
\hline Occupation FE & No & No & No & No & No & No & No & No \\
\hline \multicolumn{9}{|c|}{ Panel B: Including covariates } \\
\hline Baby Boomers & $\begin{array}{l}-0.007^{* * *} \\
(0.000)\end{array}$ & $\begin{array}{r}-0.000 \\
(0.000)\end{array}$ & $\begin{array}{l}0.004^{* * *} \\
(0.000)\end{array}$ & $\begin{array}{l}0.157^{* * *} \\
(0.008)\end{array}$ & $\begin{array}{l}0.130^{* * *} \\
(0.008)\end{array}$ & $\begin{array}{l}-0.058^{* * *} \\
(0.000)\end{array}$ & $\begin{array}{l}-0.013^{* * *} \\
(0.000)\end{array}$ & $\begin{array}{l}-0.021^{* * *} \\
(0.004)\end{array}$ \\
\hline Gen. X. & $\begin{array}{l}-0.014^{* * * *} \\
(0.000)\end{array}$ & $\begin{array}{l}-0.001^{* * *} \\
(0.000)\end{array}$ & $\begin{array}{l}0.006^{* * *} \\
(0.000)\end{array}$ & $\begin{array}{l}0.305^{* * *} \\
(0.009)\end{array}$ & $\begin{array}{l}0.256^{* * *} \\
(0.008)\end{array}$ & $\begin{array}{l}-0.109^{* * *} \\
(0.001)\end{array}$ & $\begin{array}{l}-0.025^{* * *} \\
(0.000)\end{array}$ & $\begin{array}{l}-0.050^{* * *} \\
(0.005)\end{array}$ \\
\hline Millennials & $\begin{array}{c}-0.019^{* * *} \\
(0.000)\end{array}$ & $\begin{array}{c}-0.002^{\text {*** }} \\
(0.000)\end{array}$ & $\begin{array}{l}0.007^{* * *} \\
(0.000)\end{array}$ & $\begin{array}{l}0.394^{* * * *} \\
(0.011)\end{array}$ & $\begin{array}{l}0.286^{* * *} \\
(0.010)\end{array}$ & $\begin{array}{c}-0.134^{* * *} \\
(0.001)\end{array}$ & $\begin{array}{c}-0.034^{* * *} \\
(0.000)\end{array}$ & $\begin{array}{c}-0.064^{* * *} \\
(0.006)\end{array}$ \\
\hline Observations & 57739 & 14158 & 120231 & 13102 & 20827 & 73359 & 27138 & 3172 \\
\hline Fixed Effects & No & No & No & No & No & No & No & No \\
\hline Covariates & Yes & Yes & Yes & Yes & Yes & Yes & Yes & Yes \\
\hline Occupation FE & No & No & No & No & No & No & No & No \\
\hline \multicolumn{9}{|c|}{ Panel C: Plus occupation controls } \\
\hline Baby Boomers & $\begin{array}{l}-0.007^{* * * *} \\
(0.000)\end{array}$ & $\begin{array}{c}-0.000^{* *} \\
(0.000)\end{array}$ & $\begin{array}{l}0.004^{* * *} \\
(0.000)\end{array}$ & $\begin{array}{l}0.156^{* * *} \\
(0.008)\end{array}$ & $\begin{array}{l}0.130^{* * *} \\
(0.008)\end{array}$ & $\begin{array}{l}-0.057^{* * * *} \\
(0.000)\end{array}$ & $\begin{array}{l}-0.013^{* * *} \\
(0.000)\end{array}$ & $\begin{array}{l}-0.022^{* * *} \\
(0.004)\end{array}$ \\
\hline Gen. X. & $\begin{array}{l}-0.014^{* * * *} \\
(0.000)\end{array}$ & $\begin{array}{l}-0.001^{* * *} \\
(0.000)\end{array}$ & $\begin{array}{l}0.006^{* * *} \\
(0.000)\end{array}$ & $\begin{array}{l}0.304^{* * *} \\
(0.009)\end{array}$ & $\begin{array}{l}0.257^{* * *} \\
(0.008)\end{array}$ & $\begin{array}{l}-0.107^{* * *} \\
(0.001)\end{array}$ & $\begin{array}{l}-0.025^{* * *} \\
(0.000)\end{array}$ & $\begin{array}{l}-0.052^{* * *} \\
(0.005)\end{array}$ \\
\hline Millennials & $\begin{array}{l}-0.019^{* * * *} \\
(0.000)\end{array}$ & $\begin{array}{l}-0.003^{* * *} \\
(0.000)\end{array}$ & $\begin{array}{l}0.007^{* * *} \\
(0.000)\end{array}$ & $\begin{array}{l}0.393^{* * *} \\
(0.011)\end{array}$ & $\begin{array}{l}0.288^{* * *} \\
(0.010)\end{array}$ & $\begin{array}{c}-0.131^{* * * *} \\
(0.001)\end{array}$ & $\begin{array}{c}-0.034^{* * * *} \\
(0.000)\end{array}$ & $\begin{array}{c}-0.066^{* * *} \\
(0.006)\end{array}$ \\
\hline Observations & 57739 & 14158 & 120231 & 13102 & 20827 & 73359 & 27138 & 3172 \\
\hline Fixed Effects & No & No & No & No & No & No & No & No \\
\hline Covariates & Yes & Yes & Yes & Yes & Yes & Yes & Yes & Yes \\
\hline Occupation FE & Yes & Yes & Yes & Yes & Yes & Yes & Yes & Yes \\
\hline \multicolumn{9}{|c|}{ Panel D: With state fixed effects } \\
\hline Baby Boomers & $\begin{array}{c}-0.007^{* * *} \\
(0.000)\end{array}$ & $\begin{array}{c}-0.000 \\
(0.000)\end{array}$ & $\begin{array}{l}0.004^{* * *} \\
(0.001)\end{array}$ & $\begin{array}{l}0.170^{* * *} \\
(0.020)\end{array}$ & $\begin{array}{l}0.127^{* * *} \\
(0.014)\end{array}$ & $\begin{array}{c}-0.056^{* * * *} \\
(0.002)\end{array}$ & $\begin{array}{c}-0.013^{* * * *} \\
(0.001)\end{array}$ & $\begin{array}{c}-0.026^{* * *} \\
(0.005)\end{array}$ \\
\hline Gen. X. & $\begin{array}{c}-0.014^{* * * *} \\
(0.000)\end{array}$ & $\begin{array}{c}-0.001^{*} \\
(0.001)\end{array}$ & $\begin{array}{l}0.006^{* * *} \\
(0.002)\end{array}$ & $\begin{array}{l}0.319^{* * *} \\
(0.034)\end{array}$ & $\begin{array}{l}0.245^{* * *} \\
(0.027)\end{array}$ & $\begin{array}{c}-0.105^{* * *} \\
(0.003)\end{array}$ & $\begin{array}{c}-0.025^{* * * *} \\
(0.001)\end{array}$ & $\begin{array}{c}-0.055^{* * *} \\
(0.011)\end{array}$ \\
\hline Millennials & $\begin{array}{c}-0.019^{* * *} \\
(0.000)\end{array}$ & $\begin{array}{c}-0.003^{* * *} \\
(0.001)\end{array}$ & $\begin{array}{l}0.008^{* * *} \\
(0.003)\end{array}$ & $\begin{array}{l}0.400^{* * * *} \\
(0.041)\end{array}$ & $\begin{array}{l}0.274^{* * *} \\
(0.054)\end{array}$ & $\begin{array}{c}-0.129^{* * *} \\
(0.003)\end{array}$ & $\begin{array}{c}-0.034^{* * *} \\
(0.002)\end{array}$ & $\begin{array}{c}-0.066^{* * *} \\
(0.016)\end{array}$ \\
\hline Observations & 57739 & 14158 & 120231 & 13102 & 20827 & 73359 & 27138 & 3171 \\
\hline Fixed Effects & Yes & Yes & Yes & Yes & Yes & Yes & Yes & Yes \\
\hline Covariates & Yes & Yes & Yes & Yes & Yes & Yes & Yes & Yes \\
\hline Occupation FE & Yes & Yes & Yes & Yes & Yes & Yes & Yes & Yes \\
\hline
\end{tabular}

Note: Each panel and column is a regression where the dependent variableis the labour share of value added as seen in Equation (3). Panel $\mathrm{A}$ is the regression without covariates and fixed effects. Panel B includes covariates but not fixed effects. Panel C includes additional occupation controls, and Panel D is the regression including both covariates and fixed effects. The data from the CPS and BEA are merged at the state geographic level and one-digit industry code as described in Appendix A. The generation variables are all dummy variables defined on the basis of date of birth, as per Table 1. The omitted category is the Silent Generation. Covariates include age, education, gender and race variables. Fixed effects are by state and probability weights are used. Standard errors are in parenthesis. ${ }^{* * *}$ Significant at the $1 \%$ level.** Significant at the $5 \%$ level. ${ }^{*}$ Significant at the $10 \%$ level. 


\subsection{The Labour Share}

Table 5 reports estimates of Equation (3). Looking to Panel A, which omits controls and fixed effects, we see minimal changes in labour share for all generations for workers in Wholesale and Services relative to the Silent Generation. Conversely, we see reductions in Retail, Manufacturing, Construction and Mining. Whereas similar to wages, Finance and Utilities are the exceptions showing increases in the labour share. These results are consistent with and exhibit similar patterns to the results for wages above, suggesting that intergenerational declines in median wages may reflect declines in the labour share.

Controlling for observables has a limited impact on the results, as can be seen in Panels B to D. The estimated $\gamma$ coefficients are now larger, with a similar pattern across industries as in the case without additional controls. Millennials continue to perform well in Finance and Utilities, with the Millennial labour shares of those in both sectors substantially higher than those of previous generations.

Looking at the coefficients on the control variables we see some interesting patterns. Turning to Table 6, note, that African Americans and Hispanics see no increase or negative change in labour share across generations conditional on education and age. Alternatively, we see increasing labour share across generations for those who are high school graduates and additionally have a college degree. When we look to Columns (5) through (8), which now includes industry controls, a number of covariates go to statistically insignificant or with non-consequential magnitudes, suggesting industry of work is a key driver and here we are seeing patterns from changing composition of the work force across generations.

To close we consider results pooling across industries to analyse overall differences between generations. The results are reported in Columns (5)-(8) of Table 3. Here we see, that the Gen. X'ers had the largest labour share when considering the specification without occupation and industry controls. Millennials have then a lower labour share than the Silent Generation who have a lower share than the Boomers and the Gen. X'ers. The inclusion of the additional controls, as shown in columns (7)-(8) shows that all generations perform badly in terms of labour share compared to the Silent Generation. This suggests that the substantial growth in the labour share of those employed in the Finance and Utilities sectors is sufficient to offset the minimal growth in all other sectors. It is useful to think about the exceptionalism of these sectors, in light of the findings of Guvenen et al. (2017) who show that only the top decile has seen wage growth across cohorts, and the growth of incomes in Finance documented by Philippon and Reshef (2012). Consistent with both of these findings is the possibility that the growth in wages and of the labour share in Finance and Utilities is both driven by the highest 
Table 6: Determinants of the labour share: generation specific estimates

\begin{tabular}{|c|c|c|c|c|c|c|c|c|}
\hline & $\begin{array}{c}(1) \\
\text { Silent }\end{array}$ & $\begin{array}{c}(2) \\
\text { Boomers }\end{array}$ & Gen. $\boldsymbol{X}$ & $\begin{array}{c}\text { Panel A } \\
\text { (4) } \\
\text { Millenials }\end{array}$ & $\begin{array}{c}(5) \\
\text { Silent }\end{array}$ & $\begin{array}{c}(6) \\
\text { Boomers }\end{array}$ & $\stackrel{(7)}{\text { Gen. } \boldsymbol{X}}$ & $\begin{array}{c}(8) \\
\text { Millenials }\end{array}$ \\
\hline Age & $\begin{array}{l}0.003^{* * *} \\
(0.000)\end{array}$ & $\begin{array}{l}-0.001^{* * *} \\
(0.000)\end{array}$ & $\begin{array}{l}0.004^{* * *} \\
(0.001)\end{array}$ & $\begin{array}{c}0.001 \\
(0.006)\end{array}$ & $\begin{array}{c}-0.001^{* *} \\
(0.000)\end{array}$ & $\begin{array}{l}-0.003^{\text {*** }} \\
(0.000)\end{array}$ & $\begin{array}{l}0.001^{* *} \\
(0.001)\end{array}$ & $\begin{array}{c}-0.007^{* * *} \\
(0.003)\end{array}$ \\
\hline Age Sq & $\begin{array}{l}-0.000^{* * *} \\
(0.000)\end{array}$ & $\begin{array}{l}0.000^{* * *} \\
(0.000)\end{array}$ & $\begin{array}{l}-0.000^{* * * *} \\
(0.000)\end{array}$ & $\begin{array}{c}0.000 \\
(0.000)\end{array}$ & $\begin{array}{c}0.000 \\
(0.000)\end{array}$ & $\begin{array}{l}0.000^{* * *} \\
(0.000)\end{array}$ & $\begin{array}{c}-0.000^{* *} \\
(0.000)\end{array}$ & $\begin{array}{l}0.000^{* * *} \\
(0.000)\end{array}$ \\
\hline African American & $\begin{array}{l}0.006^{* * *} \\
(0.001)\end{array}$ & $\begin{array}{l}0.005^{* * *} \\
(0.001)\end{array}$ & $\begin{array}{l}0.009^{* * *} \\
(0.001)\end{array}$ & $\begin{array}{l}0.008^{* * *} \\
(0.002)\end{array}$ & $\begin{array}{c}-0.003^{* *} \\
(0.001)\end{array}$ & $\begin{array}{l}-0.002^{* * * *} \\
(0.001)\end{array}$ & $\begin{array}{c}-0.002^{* *} \\
(0.001)\end{array}$ & $\begin{array}{r}-0.002^{*} \\
(0.001)\end{array}$ \\
\hline Hispanic & $\begin{array}{c}-0.002 \\
(0.001)\end{array}$ & $\begin{array}{l}-0.004^{* * *} \\
(0.001)\end{array}$ & $\begin{array}{c}-0.001 \\
(0.001)\end{array}$ & $\begin{array}{c}-0.000 \\
(0.002)\end{array}$ & $\begin{array}{c}-0.007^{* * * *} \\
(0.001)\end{array}$ & $\begin{array}{c}-0.006^{* * * *} \\
(0.001)\end{array}$ & $\begin{array}{c}-0.001 \\
(0.001)\end{array}$ & $\begin{array}{r}-0.002^{*} \\
(0.001)\end{array}$ \\
\hline $\begin{array}{l}\text { High School } \\
\text { Graduate }\end{array}$ & $\begin{array}{c}-0.006^{* * *} \\
(0.001)\end{array}$ & $\begin{array}{c}-0.003^{* * *} \\
(0.001)\end{array}$ & $\begin{array}{l}0.016^{* * *} \\
(0.001)\end{array}$ & $\begin{array}{l}0.021^{* * * *} \\
(0.002)\end{array}$ & $\begin{array}{c}-0.014^{* * *} \\
(0.001)\end{array}$ & $\begin{array}{l}-0.016^{* * *} \\
(0.000)\end{array}$ & $\begin{array}{c}-0.002 \\
(0.001)\end{array}$ & $\begin{array}{c}-0.001 \\
(0.001)\end{array}$ \\
\hline College & $\begin{array}{l}0.015^{* * *} \\
(0.002)\end{array}$ & $\begin{array}{l}0.017^{* * *} \\
(0.001)\end{array}$ & $\begin{array}{l}0.024^{* * *} \\
(0.001)\end{array}$ & $\begin{array}{l}0.029^{* * *} \\
(0.002)\end{array}$ & $\begin{array}{c}0.002 \\
(0.002)\end{array}$ & $\begin{array}{c}0.001^{*} \\
(0.001)\end{array}$ & $\begin{array}{l}0.004^{* * *} \\
(0.001)\end{array}$ & $\begin{array}{l}0.004^{* * *} \\
(0.001)\end{array}$ \\
\hline Female & $\begin{array}{l}0.007^{* * *} \\
(0.001)\end{array}$ & $\begin{array}{l}0.014^{\text {*** }} \\
(0.001)\end{array}$ & $\begin{array}{l}0.016^{\text {*** }} \\
(0.001)\end{array}$ & $\begin{array}{l}0.015^{* * *} \\
(0.002)\end{array}$ & $\begin{array}{c}-0.002^{* *} \\
(0.001)\end{array}$ & $\begin{array}{c}-0.001 \\
(0.000)\end{array}$ & $\begin{array}{c}-0.000 \\
(0.001)\end{array}$ & $\begin{array}{c}-0.001 \\
(0.001)\end{array}$ \\
\hline $\begin{array}{l}\text { Observations } \\
\text { Industry Controls } \\
\text { Occupation FE } \\
\text { State FE }\end{array}$ & $\begin{array}{l}51888 \\
\text { No } \\
\text { No } \\
\text { No }\end{array}$ & $\begin{array}{l}160485 \\
\text { No } \\
\text { No } \\
\text { No }\end{array}$ & $\begin{array}{l}94141 \\
\text { No } \\
\text { No } \\
\text { No }\end{array}$ & $\begin{array}{c}23212 \\
\text { No } \\
\text { No } \\
\text { No }\end{array}$ & $\begin{array}{c}51888 \\
\text { Yes } \\
\text { No } \\
\text { No }\end{array}$ & $\begin{array}{l}160485 \\
\text { Yes } \\
\text { No } \\
\text { No }\end{array}$ & $\begin{array}{c}94141 \\
\text { Yes } \\
\text { No } \\
\text { No }\end{array}$ & $\begin{array}{l}23212 \\
\text { Yes } \\
\text { No } \\
\text { No }\end{array}$ \\
\hline & $(1)$ & $(2)$ & $(3)$ & $\begin{array}{c}\text { Panel B } \\
(4)\end{array}$ & $(5)$ & $(6)$ & $(7)$ & $(8)$ \\
\hline Age & $\begin{array}{c}-0.001^{* *} \\
(0.000)\end{array}$ & $\begin{array}{l}-0.003^{* * *} \\
(0.000)\end{array}$ & $\begin{array}{l}0.001^{* *} \\
(0.001)\end{array}$ & $\begin{array}{l}-0.007^{* * * *} \\
(0.003)\end{array}$ & $\begin{array}{r}-0.001^{*} \\
(0.000)\end{array}$ & $\begin{array}{l}-0.003^{* * *} \\
(0.000)\end{array}$ & $\begin{array}{c}0.001 \\
(0.001)\end{array}$ & $\begin{array}{c}-0.007^{* *} \\
(0.003)\end{array}$ \\
\hline Age Sq & $\begin{array}{c}0.000 \\
(0.000)\end{array}$ & $\begin{array}{l}0.000^{* * *} \\
(0.000)\end{array}$ & $\begin{array}{c}-0.000^{* *} \\
(0.000)\end{array}$ & $\begin{array}{l}0.000^{* * *} \\
(0.000)\end{array}$ & $\begin{array}{c}0.000 \\
(0.000)\end{array}$ & $\begin{array}{l}0.000^{* * *} \\
(0.000)\end{array}$ & $\begin{array}{c}-0.000 \\
(0.000)\end{array}$ & $\begin{array}{l}0.000^{* * *} \\
(0.000)\end{array}$ \\
\hline African American & $\begin{array}{c}-0.002 \\
(0.001)\end{array}$ & $\begin{array}{c}-0.001^{*} \\
(0.001)\end{array}$ & $\begin{array}{c}-0.002^{* *} \\
(0.001)\end{array}$ & $\begin{array}{r}-0.002^{*} \\
(0.001)\end{array}$ & $\begin{array}{c}0.000 \\
(0.001)\end{array}$ & $\begin{array}{c}0.001 \\
(0.001)\end{array}$ & $\begin{array}{c}0.000 \\
(0.002)\end{array}$ & $\begin{array}{c}-0.000 \\
(0.001)\end{array}$ \\
\hline Hispanic & $\begin{array}{c}-0.006^{* * *} \\
(0.001)\end{array}$ & $\begin{array}{l}-0.006^{* * *} \\
(0.001)\end{array}$ & $\begin{array}{c}-0.001 \\
(0.001)\end{array}$ & $\begin{array}{r}-0.002^{*} \\
(0.001)\end{array}$ & $\begin{array}{l}-0.005^{* * *} \\
(0.001)\end{array}$ & $\begin{array}{c}-0.004^{* *} \\
(0.002)\end{array}$ & $\begin{array}{c}0.000 \\
(0.001)\end{array}$ & $\begin{array}{c}-0.000 \\
(0.001)\end{array}$ \\
\hline $\begin{array}{l}\text { High School } \\
\text { Graduate }\end{array}$ & $\begin{array}{c}-0.015^{* * *} \\
(0.001)\end{array}$ & $\begin{array}{c}-0.017^{* * *} \\
(0.000)\end{array}$ & $\begin{array}{c}-0.002 \\
(0.001)\end{array}$ & $\begin{array}{c}-0.000 \\
(0.001)\end{array}$ & $\begin{array}{l}-0.015^{* * *} \\
(0.002)\end{array}$ & $\begin{array}{c}-0.017^{* * * *} \\
(0.001)\end{array}$ & $\begin{array}{r}-0.002^{*} \\
(0.001)\end{array}$ & $\begin{array}{c}-0.001 \\
(0.001)\end{array}$ \\
\hline College & $\begin{array}{c}0.000 \\
(0.002)\end{array}$ & $\begin{array}{l}0.000 \\
(0.001)\end{array}$ & $\begin{array}{l}0.003^{* * *} \\
(0.001)\end{array}$ & $\begin{array}{l}0.004^{* * *} \\
(0.001)\end{array}$ & $\begin{array}{c}-0.000 \\
(0.002)\end{array}$ & $\begin{array}{c}-0.001 \\
(0.001)\end{array}$ & $\begin{array}{l}0.002^{*} \\
(0.001)\end{array}$ & $\begin{array}{l}0.002^{* *} \\
(0.001)\end{array}$ \\
\hline Female & $\begin{array}{l}-0.003^{* * *} \\
(0.001)\end{array}$ & $\begin{array}{c}-0.001^{* *} \\
(0.001)\end{array}$ & $\begin{array}{c}-0.001 \\
(0.001)\end{array}$ & $\begin{array}{c}-0.001 \\
(0.001)\end{array}$ & $\begin{array}{l}-0.003^{* * *} \\
(0.001)\end{array}$ & $\begin{array}{c}-0.001^{\text {*** }} \\
(0.000)\end{array}$ & $\begin{array}{c}-0.001 \\
(0.001)\end{array}$ & $\begin{array}{c}-0.001 \\
(0.001)\end{array}$ \\
\hline Observations & 51888 & 160485 & 94141 & 23212 & 51888 & 160485 & 94141 & 23212 \\
\hline Industry Controls & Yes & Yes & Yes & Yes & Yes & Yes & Yes & Yes \\
\hline Occupation FE & Yes & Yes & Yes & Yes & Yes & Yes & Yes & Yes \\
\hline State FE & No & No & No & No & Yes & Yes & Yes & Yes \\
\hline
\end{tabular}

Note: Each panel and column is a regression where the dependent variableis the labour share of value added as seen in Equation (3) but pooling across industries and disaggregating instead by generation. Panel A is the regression without fixed effects. Panel B includes fixed effects in columns (5) to (8).

Moreover, columns (1) to (4) in panel A do not include industry controls whereas Columns (5) to (8) do. The data from the CPS and BEA are merged at the state geographic level and one-digit industry code as described in Appendix A. Generation is defined on the basis of date of birth, as per Table 1. Fixed effects are by state and probability weights are used. Standard errors are in parenthesis. ${ }^{* * *}$ Significant at the $1 \%$ level.** Significant at the $5 \%$ level. * Significant at the $10 \%$ level. 
earners in those sectors, and that these sectors account for much of the overall growth in the incomes of the highest earners.

\subsection{Heterogeneity}

We have so far focused on average earnings, but prior work such as Piketty and Saez (2003), Gabaix et al. (2016) has highlighted the changing shape of the earnings distribution and particularly the concentration of earnings growth on the top centiles of the distribution. Others, including Chetverikov et al. (2016), have documented the uneven impact of secular changes such as increased import competition. This raises the question, of whether the trends identified above have affected those in some parts of the distribution more than others. To investigate this possibility we estimate quantile regressions analogous to Equation 3. Figure 8 plots the results of these regressions estimated separately for men and women. The results for men make clear that across the distribution we observe declines in real earnings with each subsequent generation. Interestingly, however, the differences between generations are smallest at the extremes of the distribution. One explanation is that the low earnings of the poorest $5 \%$ inevitably compress the distribution, while the increasing earnings of the very richest, documented by Gabaix et al. (2016) and others, push up the average earnings of the richest 5\%.

The results for women in the right-hand panel reveal interesting differences in fortunes between the top and bottom halves of the distribution. Women below the median have seen substantial income growth with Millennials at the 10th percentile earning $\exp (0.39)-1=48 \%$ more than their Silent equivalents. Gen X. and Boomer women earn $26 \%$ and $19 \%$ more respectively. On the other hand, Boomer women out earn their subsequent counterparts by an increasing degree from the median onwards. Although, as with men, there is some convergence at the 95th percentile. This relative growth in the incomes of lower-earning women is consistent with the results from social-security data of Kopczuk et al. (2010) who document a decreasing p50/p20 ratio for women from the 1970s onwards. ${ }^{13}$

The picture becomes more nuanced when we also separate by education as well. Looking at Figure 9 we can see that while there has been growth in the lower third of the earnings distribution of female high school graduates, wages for the rest have been stagnant from the Boomers onwards. College educated women have seen more growth, again particularly at the bottom end where some difference between Gen. X'ers and Millennials is discernable. But, at above median earnings there is less evidence of such a difference although there is still an increase relative to female Boomer college-graduates of

\footnotetext{
${ }^{13}$ Kopczuk et al. (2010) also present evidence of an increasing p80/p20 ratio - which we do not observe suggesting that it is captured by our other controls, such as education.
} 
around $\exp (0.38)-\exp (0.21)=23.4 \%$. Arguably, given the two secular trends of a shrinking gender pay gap (Goldin, 2014), and skills-biased technological change, this number seems small.

The results for college educated men tell a similar story. Across the distribution, incomes are highest for Gen. X'ers, although they are only one or two percent higher than those of Millennials. The gap with Boomers (and Silents) is largest at the bottom of the distribution where it is around $16.1 \%$, although these estimates are less precise. The top $10 \%$ of all three generations have experienced substantial income growth relative to the Silents, consistent with the overall earnings growth of the highest earners. The results for High-School graduates mirror those for men as a whole in Figure 8, with a clear reduction in earnings of each subsequent generation across the distribution.

Figure 10 reports results estimated separately for each of the three largest ethnic and racial groups in our data. ${ }^{14}$ The results for Whites again show a clear reduction in earnings across generations. There is some evidence of wage growth amongst the lowest-earning African Americans, particularly for Gen. X'ers. But, any such gains are restricted to the bottom $25 \%$. The remainder of the distribution suffered a decline smaller than that of Whites, but given that conditional on age, education, and location, African Americans earned 29\% less than Whites in 1950 (Black et al., 2013), this suggests that subsequent generations have seen only a modest reduction in the racial wage gap. Likewise the earnings of Hispanics have seen some growth at the bottom of the distribution, but otherwise the same pattern of reduced earnings for each subsequent generation emerges. For Hispanics however, the magnitude of the coefficients are similar to those for Whites, although there is not the same convergence at the top of the earnings distribution. Perhaps, reflecting that Hispanics are underrepresented amongst the highest earners.

Taken together the results suggest that women and non-Whites in the lowest quantiles have seen some growth in real incomes between generations. But, the majority have experienced declines. Otherwise the results are consistent with the trends identified above for average earnings. One further interesting phenomenon is that intergenerational differences seem to be smaller amongst the top $5 \%$ of each group.

\section{Variance decomposition}

Having found evidence for intergenerational differences in wages and the labour share, we now ask how important these are relative to other changes in the US economy over the period we study. As well as the key change of increased female labour force participation and skill-biased technological change there have also been changes in the geographic distribution of economic activity away from the

\footnotetext{
${ }^{14}$ Sample size limitations preclude analysis of other groups.
} 
Figure 8: Quantile regression results

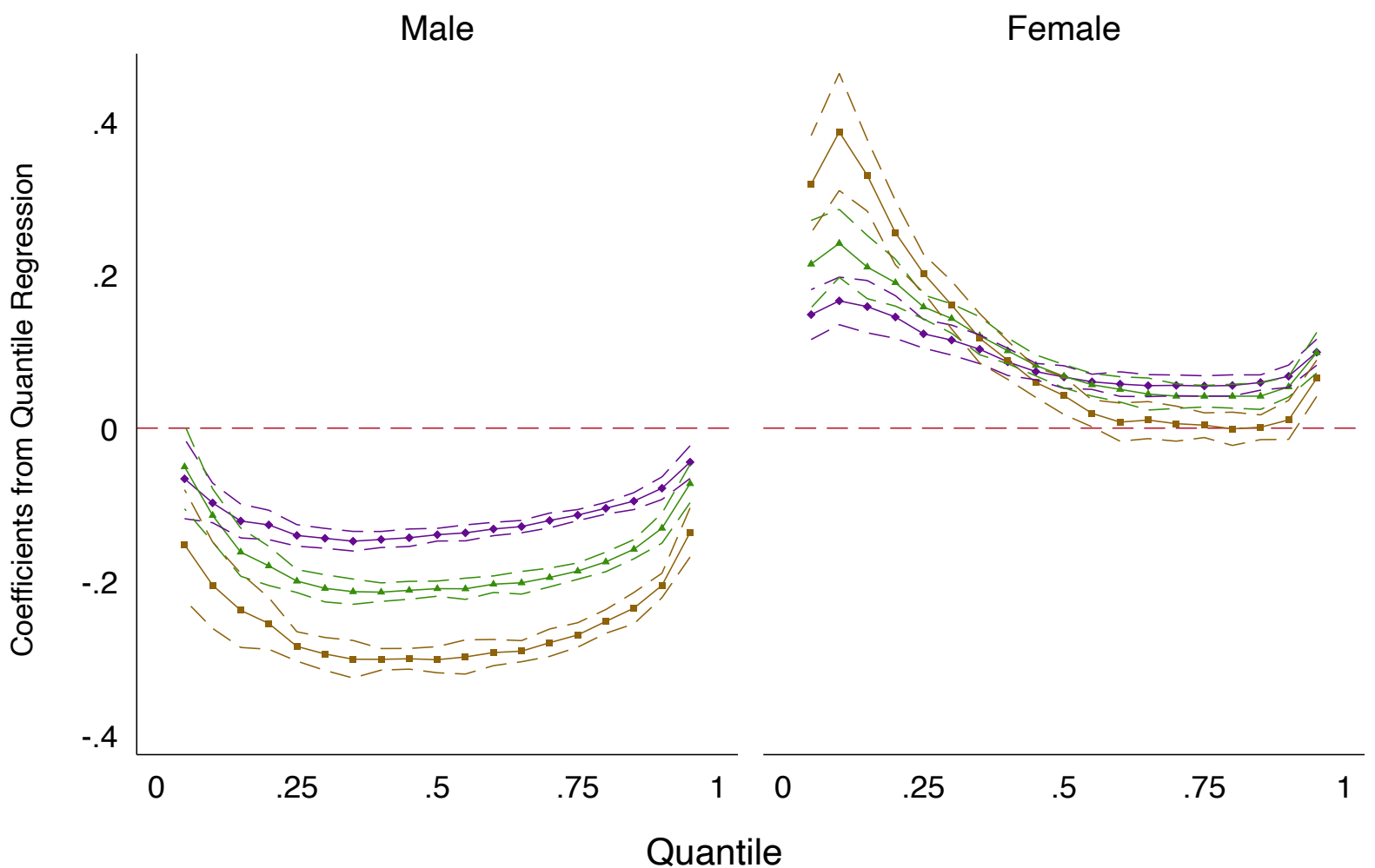

$\rightarrow$ Boomers $\rightarrow$ Gen. X $\rightarrow$ Millennials

Notes: Each panel reports the coefficient on the generation dummies from the following quantile regressions estimated separately for men and women:

$$
c_{j, t}^{\tau}=\gamma_{g}(\tau)+X_{j, t}^{\prime} \beta(\tau)+\delta_{s}(\tau)+\varepsilon_{j, t}(\tau)
$$

Where $c_{j, t}^{\tau}$ is the $\tau^{t h}$ quantile of $\log$ wage for individual $j$ in year $t$. $\gamma_{g}(\tau)$ is the vector of generational dummies, the coefficients of which are plotted above, with the base generation being the Silent generation. $X_{j, t}^{\prime} \beta(\tau)$ is number of controls including, individual controls, and industry controls. $\delta_{s}(\tau)$ is state fixed effects. The dashed lines are the corresponding 95\% confidence interval. Data are from the CPS, our core regression sample as constructed in Appendix A.

Rust Belt and towards the South and West. There has also been substantial changes in the relative importance of different sectors, with the decline of manufacturing being one prominent example. In this section we employ a variance-decomposition analysis to understand the quantitative importance of these different trends, and specifically the relative importance of intergenerational differences.

Rather than focus on the individual coefficients $\gamma$ and $\beta$, we now ask instead how much of the variation in log wages or the labour share can be explained by each set of variables. If a particular variable, or group of variables, can explain a lot of the variation then it clearly an economically significant determinant. On the other hand, a precisely estimated coefficient that cannot explain much of the variation is not. 
Figure 9: Quantile regression results

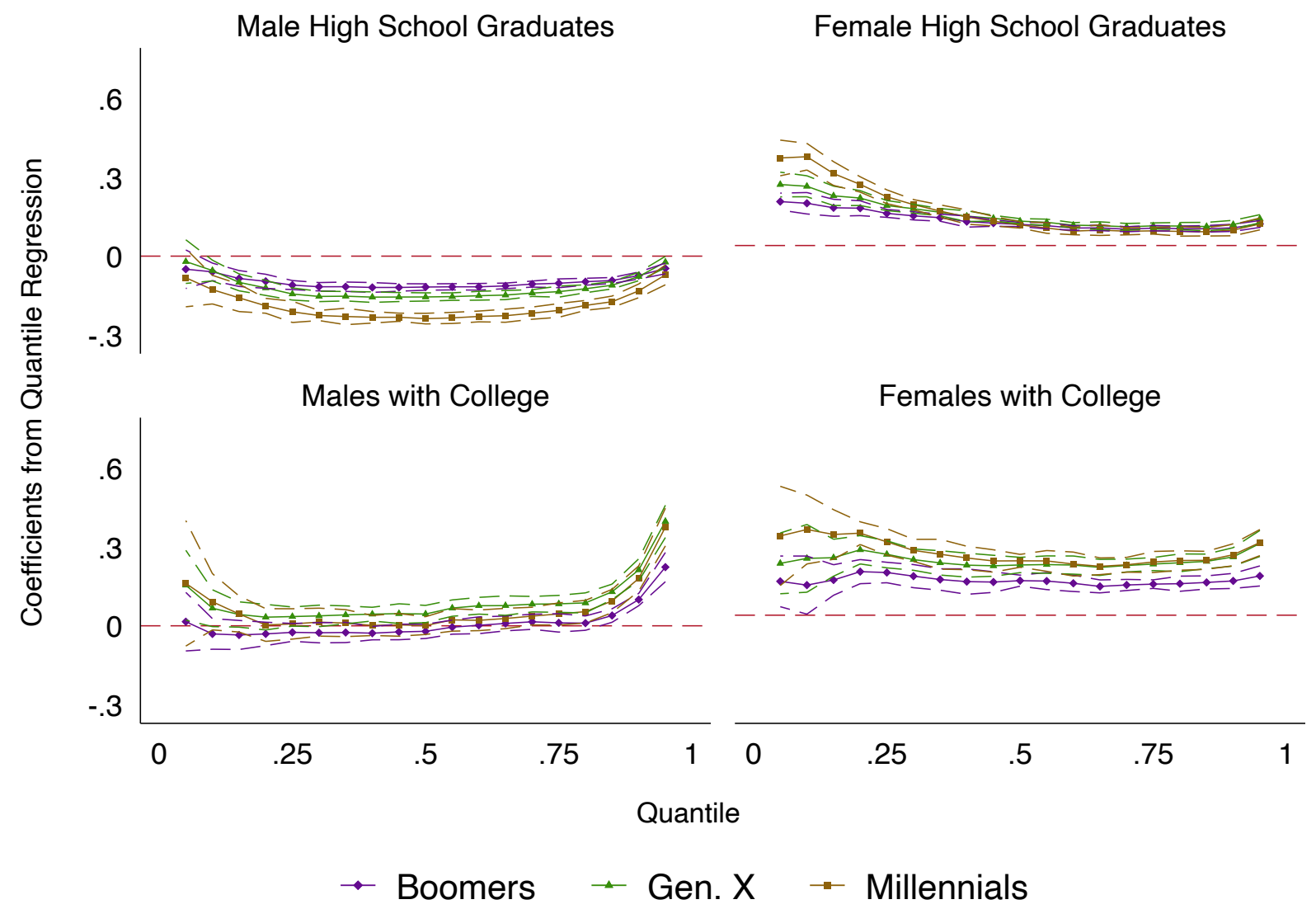

Notes: Results are for separate quantile regressions, for men and women with highschool or college educations respectively. Other details as for Figure 8.

\subsection{Variance decomposition estimators}

To begin, following the approach of Gibbons et al. (2014), consider a simplified version of Equation (3) in which we pool across industries:

$$
c_{j, t}=d_{s}^{\prime} \delta+X_{j, t}^{\prime} \beta+\varepsilon_{j, t}
$$

We now write $\delta_{s}$ as $d_{s}^{\prime} \delta$ as it will be useful to distinguish between the data and the parameters below. Here, we are abstracting for now from generation and industry, and focussing on the quantitative importance of where an individual lives and their characteristics. That is, we wish to distinguish between the idea that individuals in richer states earn more because the best and the brightest move to those states versus the hypothesis that it is the nature of the richer states themselves, whether it be natural resources, geography, or infrastructure, etc., that means that otherwise identical workers earn more there. 
Figure 10: Quantile regression results

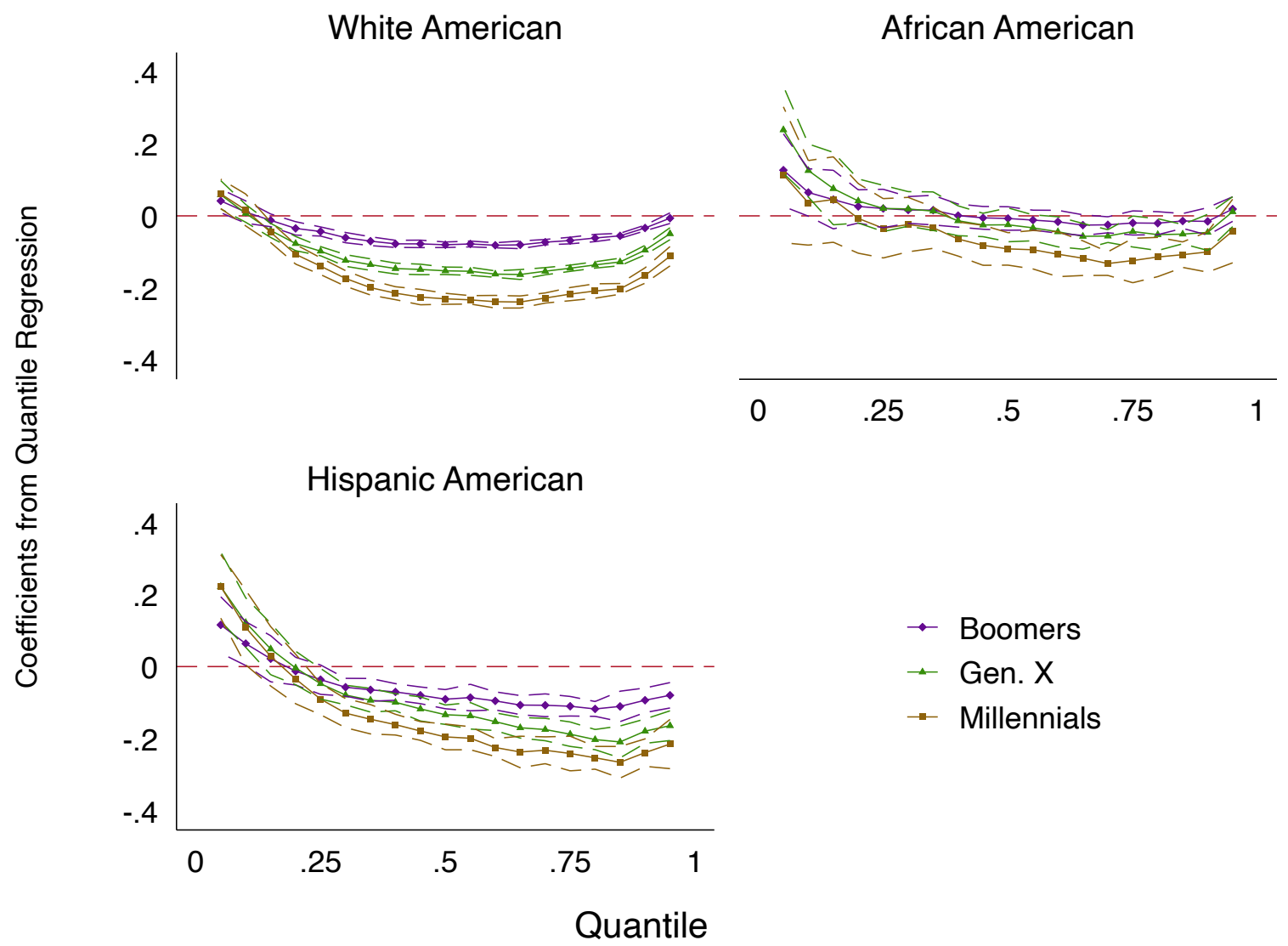

Notes: Results are for separate quantile regressions for Black, Hispanic, and White Americans. Other details as for Figure 8.

The complication emerges since it is both reasonable to believe that the state effects, $\delta_{s}$, are a composite of the exogenous features of each state and the characteristics of those that live there. At the same time as maintaining that the individual characteristics, such as education, will depend in part on where the individual lives as well as on their innate characteristics. A further complication is sorting: that people may endogenously relocate based on their characteristics.

Gibbons et al. (2014) discuss how alternative assumptions about what determines the state and individual effects give rise to a number of alternative variance-decomposition estimators. Their starting point is the Raw Variance Share $(R V S)$, which estimates the effects of states as simply the $R^{2}$ of a simple regression which includes only state dummies. Thus, the $R V S$ provides an upper-bound on what proportion of the variation of earnings is due to location, since it takes into account no other differences between workers than their location.

It is more plausible to assume that some of the variation in wages between areas is due to the composition of the labour force. An extreme approach is to focus only on the area effects that are uncorrelated with the individual effects, that is to assume that state characteristics are responsible 
for none of the variation in individual characteristics. As Gibbons et al. (2014) term this estimator the Uncorrelated Variance Share (UVS) and it is most easily thought of as the difference in the $R^{2}$ of a regression including individual and area effects compared to a regression only including individual effects. Formally,

$$
U V S=R^{2}\left(c_{j, t} ; X_{j, t}^{\prime} \hat{\beta}, d_{s}^{\prime} \hat{\delta}\right)-R^{2}\left(c_{j, t} ; X_{j, t}^{\prime} \hat{\beta}\right)
$$

Where $R^{2}\left(c_{j, t} ; X_{j, t}^{\prime} \hat{\beta}, d_{s}^{\prime} \hat{\delta}\right)$ is the $R^{2}$ from estimating Equation (4), and and $R^{2}\left(c_{j, t} ; X_{j, t}^{\prime} \hat{\beta}\right)$ is the $R^{2}$ is from a similar regression which does not include the state dummy variables.

An intermediate approach is rather than assuming that all of the variation is due to state characteristics (as for the $R V S$ ) or that state effects are only what cannot be explained by the (observed) characteristics of their populations (the $U V S$ ), is that there is a relationship between state characteristics and their populations. An intuitive approach is the Correlated Variance Share $(C V S)$, which is the estimated variance share of location conditional on individual characteristics. That is, it is the variance share allowing for state and individual characteristics to be correlated. Substantively, this means it attributes to the area effect, the effects due to the composition in terms of individual characteristics of the area, but not the effects of the area on its composition. Put differently, it attributes to the area the effects of the overall distribution of characteristics but does not allow for the possibility that the area may affect education outcomes, or induce sorting across areas. It may be computed as follows:

$$
C V S=\frac{\operatorname{var}\left(d_{s}^{\prime} \hat{\delta}\right)}{\operatorname{var}\left(c_{j, t}\right)}
$$

A prominent related approach is the estimator of Abowd et al. (1999) which Gibbons et al. (2014) term the Balanced Variance Share (BVS). This last method builds upon $C V S$, but explicitly addresses the issue of sorting, or other ways in which areas may influence individual characteristics. Specifically, it includes the covariance between location and individual characteristics. This, in effect, attributes half of the effects of sorting to the area effects (and the other half to individuals).

$$
B V S=\frac{\operatorname{var}\left(d_{s}^{\prime} \hat{\delta}\right)+\operatorname{cov}\left(d_{s}^{\prime} \hat{\delta}, X_{j, t}^{\prime} \hat{\beta}\right)}{\operatorname{var}\left(c_{j, t}\right)}
$$

We will present all four estimators since the $R V S$ and the $U V S$ capture the upper and lower limits of the area effects while comparing the $C V S$ and the $B V S$ to the $U V S$ allows us to recover the correlation between individuals and areas, and the extent of endogenous sorting across areas. ${ }^{15}$

\footnotetext{
${ }^{15}$ Note that, unlike the $R V S, U V S$, and $C V S$ which all take values between 0 and 1 , the $B V S$ can take any value on the real line depending on the covariance terms.
} 


\subsection{Variance decomposition estimates}

We now return to our main model which is a variant of Equation (3) which pools across industries but potentially includes industry fixed effects. That is,

$$
c_{j, t}=\gamma_{g}+X_{j, t}^{\prime} \beta+d_{s}^{\prime} \delta_{s}+d_{i}^{\prime} \delta_{i}+\varepsilon_{j, t}
$$

where $d_{i}^{\prime} \delta_{i}$ are industry fixed effects and all other terms are as in Equations (3) and (4). Now, given that there are more than two sets of coefficients the formulae for $B V S$ is slightly more complicated. ${ }^{16}$ For an arbitrary variable $d_{z}^{\prime} \delta_{z}$ we have that:

$$
B V S\left(\hat{\delta_{z}}\right)=\frac{\operatorname{var}\left(d_{z}^{\prime} \hat{\delta_{z}}\right)}{\operatorname{var}\left(c_{j, t}\right)}+\sum_{z \neq w} \frac{\operatorname{cov}\left(d_{z}^{\prime} \hat{\delta_{z}}, d_{w}^{\prime} \hat{\delta_{w}}\right)}{\operatorname{var}\left(c_{j, t}\right)}
$$

Table 7 reports $U V S, C V S$, and $B V S$ computed from estimates of Equation (8). The first column reports results for a restricted model only including $d_{t}^{\prime} \delta_{t}$ and $d_{s}^{\prime} \delta_{s}$ which corresponds to the $R V S$ estimate measure. Considering first the estimates for log wages in Panel (a) we can see that location alone explains relatively little of the variation in wages across state - around $1.65 \%$. Note that all of the results in Column (1) are identical since in the case of only one set of regressors all three estimators we consider collapse to the $R V S$ (i.e. the $R^{2}$ of the state fixed effects). Column (2) reports results containing both individual characteristics and state and year fixed effects. Now, the explanatory power of the state fixed effects is lower, in every case less than $1 \%$. The explanatory power of the individual characteristics is around $22 \%$, with little variation across the different estimates. This figure seems intuitively plausible since we expect education, experience (age), and gender to be important predictors of earnings but there will remain considerable unobserved heterogeneity.

Column (3) additionally includes industry fixed effects. These themselves explain between 2.86$4.14 \%$ of the variance in earnings. There is now also more dispersion between the BVS, CVS, and $U V S$ with $B V S-C V S \approx C V S-U V S \approx 1 \%$ suggesting that both sorting across states and industries (BVS-CVS) and the state and industry composition of the labour market (CVS-UVS) are important. Interestingly, these effects are of a similar order to the direct variance share of states and industries suggesting that the indirect effects of states and industries on earnings due to differences in who works in them and sorting is similar to the direct effects of the characteristics of the states/industries themselves. Lastly, in Column (4) we consider occupation fixed effects. Here we see occupation accounts for between $5.5-11 \%$ of the variation in wage, with minimal impact on the importance of

\footnotetext{
${ }^{16}$ The expressions for $C V S, R V S$, and $U V S$ are essentially as before. See Gibbons et al. (2014) for details.
} 
Table 7: Variance decomposition

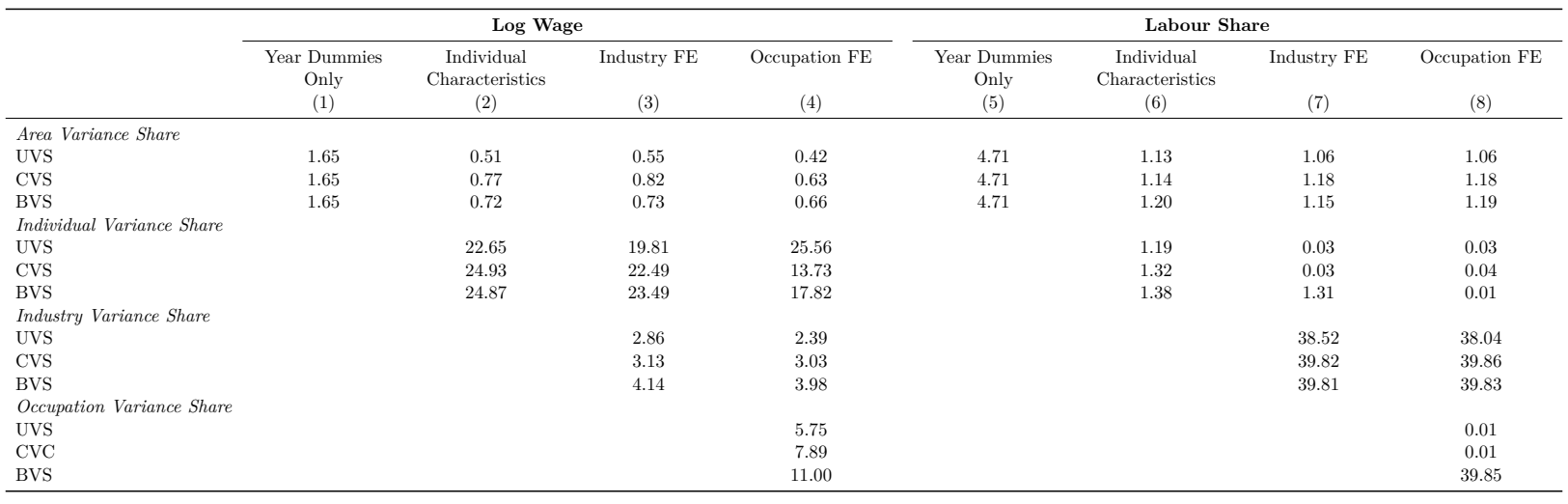

Notes: This table reports the results of a variance decomposition based on a estimates of the following regression:

$$
c_{j, t}=\gamma_{g}+X_{j, t}^{\prime} \beta+d_{s}^{\prime} \delta_{s}+d_{i}^{\prime} \delta_{i}+\varepsilon_{j, t}
$$

The included individual characteristics are age, gender, race and education dummies in addition to the generation dummies. See Section 4.1 for definitions of $U V S, C V S$ and $B V S$. All of the above numbers are percentages.

occupation and state variance share. There is some reduction in the individual variance share, yet the CVS is stil $14 \%$.

Having seen that state and industry are comparatively unimportant for wages compared to individual characteristics, Panel (a) of Table 8 reports estimates of Equation (8) where the set of individual characteristics is disaggregated into education, generation and demographic groups. Given the evidence of stagnating and indeed declining wages, we expect that the variance share of generation should be either 0 or weakly negative. First, looking down both columns we see that the inclusion of industry effects makes little difference. The impact of the education attainment variables ranges from $8.11-8.69 \%$ for the $U V S$ to nearly $11.86-11.93 \%$ for the $B V S$. This suggests that education accounts for about half of the effect of the individual characteristics. Looking at the Demographic controls we can see estimates range from as much as $18.83-21.28 \%(U V S)$ to $10.97-12.01 \%(B V S)$. Once we include occupation, we see a small decrease in the variance share, with education now accounting for $2.25-6.70 \%$. Crucially, the estimated share of generational differences is around 0, except for the BVS where it is $-1.21,-1.91 \%$ and $-3.62 \%$ excluding and including industry and occupation dummies, respectively. This suggests that the sum of the correlations between the generational dummies and education and demographic dummies is negative and that as such education, race, age, and gender explain less of the variation in wages for generations subsequent to the Silent Generation. ${ }^{17}$ Since the total sum of squares for Equation (8) must always be 1 for a given a set of estimates $\hat{\delta}$ the negat-

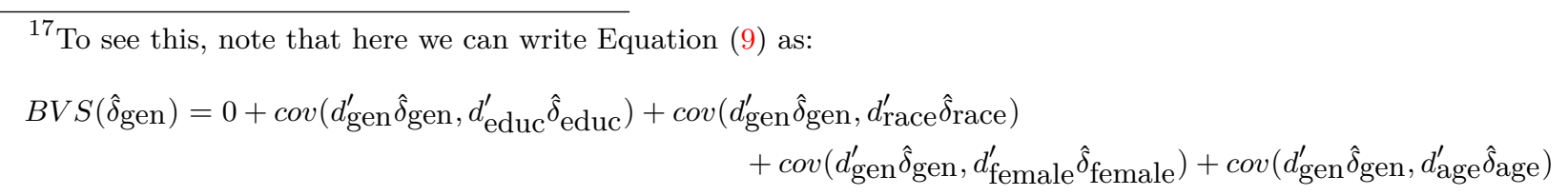

Given that all of $\delta_{g e n}$ are binary variables it must be the case that the variance explained by the other characteristics is lower when one element of $\delta_{g e n}$ is 1 . 
ive correlation with the observed demographic characteristics must be offset by a positive correlation elsewhere, potentially with an interaction of observed characteristics or unobserved characteristics.

Table 8: Variance decomposition: individual breakdown

\begin{tabular}{|c|c|c|c|c|c|c|}
\hline & \multicolumn{3}{|c|}{ Log Wage } & \multicolumn{3}{|c|}{ Labour Share } \\
\hline & $\begin{array}{c}\text { Individual } \\
\text { Characteristics } \\
\text { (1) }\end{array}$ & $\begin{array}{c}\text { Industry FE } \\
(2)\end{array}$ & $\begin{array}{c}\text { Occupation FE } \\
(3)\end{array}$ & $\begin{array}{c}\text { Individual } \\
\text { Characteristics } \\
(4)\end{array}$ & $\begin{array}{c}\text { Industry FE } \\
(5)\end{array}$ & $\begin{array}{c}\text { Occupation FE } \\
(6)\end{array}$ \\
\hline \multicolumn{7}{|c|}{ Education Variance Share } \\
\hline UVS & 8.69 & 8.11 & 2.25 & 0.80 & 0.02 & 0.02 \\
\hline CVS & 11.02 & 10.88 & 3.86 & 0.75 & 0.02 & 0.02 \\
\hline BVS & 11.93 & 11.86 & 6.70 & 0.82 & 0.70 & -0.03 \\
\hline \multicolumn{7}{|c|}{ Generation Variance Share } \\
\hline UVS & 0.02 & 0.02 & 0.01 & 0.00 & 0.01 & 0.01 \\
\hline CVS & 0.03 & 0.02 & 0.01 & 0.01 & 0.01 & 0.01 \\
\hline BVS & -1.21 & -1.91 & -3.61 & 3.26 & 22.91 & -1.64 \\
\hline \multicolumn{7}{|c|}{ Standard Controls Variance Share } \\
\hline UVS & 21.28 & 18.83 & 10.02 & 1.18 & 0.02 & 0.03 \\
\hline CVS & 24.69 & 22.32 & 13.60 & 1.31 & 0.03 & 0.03 \\
\hline BVS & 24.64 & 23.30 & 17.67 & 1.36 & 1.27 & -0.01 \\
\hline
\end{tabular}

Notes: This table reports the results of a variance decomposition based on a estimates of the following regression:

$$
c_{j, t}=\gamma_{g}+X_{j, t}^{\prime} \beta+d_{s}^{\prime} \delta_{s}+d_{i}^{\prime} \delta_{i}+\varepsilon_{j, t}
$$

The included individual characteristics, in $X$ are age, gender, race and education dummies in addition to the generation dummies. See Section 4.1 for definitions of $U V S, C V S$, and BVS. All of the above numbers are percentages. We consider standard controls to be gender, race, age and education variables. Generation includes the generation dummies and education is comprised of the dummies relating to education outcome. All of the above numbers are percentages.

Thus, the results for log wages suggest that differences between generations have limited explanatory power which is consistent with stagnating average real wages. We also found limited importance for state of residence and industry. The results for the labour share in Panel (b) of Tables 7 and 8 point in the opposite direction. Looking at Table 7 we can see that state is more important than it was for wages, but the big change is that industry explains around two fifths of the variance in the labour share. This compares with only around $1.31 \%$ for individual characteristics. When, as reported in Table 8, we separate out these individual characteristics we can see that now generation explains between 0 (UVS) and $3.26 \%$ (BVS) without industry dummies, and between 0.01 and $22.91 \%$ with them. Similarly, the inclusion of occupation fixed effects has little impact.

To better understand the changes in what determines earnings across generations without too much complication Table 9 reports decomposition estimates by generation. Looking first at the results for wages we can see that, while always relatively unimportant, the impact of state on earnings has fallen from around $0.98 \%$ for the Silent Majority to around $0.68 \%$ for Millennials. Indeed this pattern of declining explanatory power also appears for the individual variance shares for which the $C V S$ falls from $14.41 \%$ to $11.24 \%$ and for the industry variance share there is an decrease from $3.80 \%$ to $2.77 \%$. For the labour share, the key change is that the role of industry more than doubles from around $32.01 \%$ for the Silent Generation to $71.89 \%$ for Millennials. This increasing role of industry is consistent with the literature on the sorting of workers across firms, for example Abowd et al. (1999) and Song et al. (2018). Song et al. (2018) show that two thirds of the rise of inequality since 1981 can be accounted for by the increased variance of earnings across firms. 
Table 9: Variance decomposition: for each generation

\begin{tabular}{|c|c|c|c|c|c|c|c|c|}
\hline & \multicolumn{4}{|c|}{ Log Wage } & \multicolumn{4}{|c|}{ Labour Share } \\
\hline & $\begin{array}{c}\text { Silent } \\
\text { (1) }\end{array}$ & $\begin{array}{l}\text { Boomers } \\
\text { (2) }\end{array}$ & $\begin{array}{c}\text { Gen. X } \\
(3)\end{array}$ & $\begin{array}{l}\text { Millennial } \\
(4)\end{array}$ & $\begin{array}{l}\text { Silent } \\
(5)\end{array}$ & $\begin{array}{l}\text { Boomers } \\
(6)\end{array}$ & $\begin{array}{c}\text { Gen. X } \\
(7)\end{array}$ & $\begin{array}{c}\text { Millennial } \\
\text { (8) }\end{array}$ \\
\hline \multicolumn{9}{|c|}{ State Variance Share } \\
\hline UVS & 0.68 & 0.45 & 0.40 & 0.52 & 1.10 & 1.10 & 1.32 & 1.17 \\
\hline CVS & 0.98 & 0.67 & 0.58 & 0.68 & 1.32 & 1.19 & 1.50 & 1.44 \\
\hline BVS & 1.14 & 0.73 & 0.57 & 0.64 & 1.50 & 1.18 & 1.48 & 1.46 \\
\hline \multicolumn{9}{|c|}{ Individual Variance Share } \\
\hline UVS & 10.83 & 9.74 & 10.23 & 8.91 & 0.03 & 0.03 & 0.01 & 0.01 \\
\hline CVS & 14.41 & 14.04 & 13.84 & 11.24 & 0.04 & 0.03 & 0.01 & 0.00 \\
\hline BVS & 19.12 & 17.99 & 17.78 & 14.62 & -0.01 & -0.03 & 0.05 & -0.01 \\
\hline \multicolumn{9}{|c|}{ Industry Variance Share } \\
\hline UVS & 2.70 & 2.57 & 1.89 & 2.08 & 25.86 & 34.86 & 41.66 & 74.29 \\
\hline CVS & 3.80 & 3.18 & 2.26 & 2.77 & 32.01 & 35.84 & 44.18 & 71.89 \\
\hline BVS & 5.50 & 3.95 & 3.10 & 3.88 & 32.08 & 35.73 & 44.22 & 71.92 \\
\hline \multicolumn{9}{|c|}{ Occupation Variance Share } \\
\hline UVS & 6.21 & 6.20 & 5.16 & 3.87 & 0.02 & 0.00 & 0.01 & 0.00 \\
\hline CVS & 8.53 & 8.57 & 7.19 & 5.10 & 0.03 & 0.01 & 0.01 & 0.00 \\
\hline BVS & 11.49 & 11.57 & 10.51 & 8.25 & -0.09 & -0.04 & 0.05 & 0.04 \\
\hline
\end{tabular}

Notes: This table reports the results of a variance decomposition based on a estimates of the following regression:

$$
c_{j, t}^{g}=X_{j, t}^{\prime} \beta^{g}+d_{s}^{\prime} \delta_{s}+d_{i}^{\prime} \delta_{i}+\varepsilon_{j, t}
$$

The included individual characteristics, in $X$ are age, gender, race and education dummies in addition to the generation dummies. See Section 4.1 for definitions of $U V S, C V S$, and BVS. All of the above numbers are percentages. We consider standard controls to be gender, race, age and education variables. Generation includes the generation dummies and education is comprised of the dummies relating to education outcome. All of the above numbers are percentages.

To summarise, our variance decomposition analysis suggests little role for generational identity in determining real log wages, consistent with stagnating incomes. We also find that generation does play more of a role in explaining the variation in the labour share, but that, consistent with the literature on inter-firm inequality, is much less than the growing role of industry as a determinant.

\section{Hedonic improvement}

While working with real wages means we are allowing for the fact that the price level varies over time, it does not satisfactorily adjust for changes in quality. Thus, if the average loaf of bread (or phone) consumed by a member of the Silent Generation is qualitatively worse than that of the typical Millennial then our results will overstate the decline in living standards. This section asks what degree of hedonic progress we need assume for there to be equality across generations. We thus compute the equivalent variation in income necessary to make welfare equal across generations. Our approach is related to that of Jones and Klenow (2016) who compare welfare across countries by allowing for differences in hours worked, life-expectancy and inequality as well as consumption. They then obtain estimates of the equivalent consumption variation such that welfare is equalised across countries.

We begin by considering a very simple setting in which the median member of a given generation's utility in each period $t$ depends only on their income $y_{t}$ scaled by the relative quality level $h_{t}$. They, thus have a lifetime of income and, ignoring bequests, consumption such that $Y=\sum_{t} y_{t}$. Therefore we write lifetime utility as, 


$$
U=\sum_{t} u\left(y_{t} h_{t}\right)
$$

Assuming log utility, then we have that we can rewrite lifetime consumption utility as,

$$
U=\sum \ln y_{t} h_{t}=\sum \ln y_{t}+\sum \ln h_{t}
$$

We observe $\sum_{t} \ln y_{t}^{c}$ for each cohort $c$. We can denote the total utility of the cohort with the highest life cycle income $\sum \ln y_{t}^{c}$ as

$$
U^{*}=\sum_{t} \ln y_{t}^{*}+\sum_{t} \ln h_{t}^{*}
$$

If there is no intergenerational difference in consumption utility, then we simply have that $U^{c}=$ $U^{*} \forall c$. Using this, and ignoring differences in life expectancy, we can then compute the implied relative quality level,

$$
H^{c}=\frac{\bar{h}^{c}}{\bar{h}^{*}}=\frac{\sum_{t} h_{t}^{c}}{\sum_{t} h_{t}^{*}}=\exp \left[\ln \prod_{t} y_{t}^{*}-\ln \prod_{t} y_{t}^{c}\right]
$$

Figure 11 plots the estimated value of $H^{c}$ for both wages (left $y$-axis) and income (right $y$-axis) by year born. Given that, as we saw in Figure 1, the highest lifetime earnings are for those born around $1930 H_{c}$ is close to 1 for this cohort. Those born earlier were poorer and so they would have had to enjoyed a higher quality level to have the same level of welfare as the Silent Generation. Given the rapid rate of technological and societal progress between, say, 1900 and 1930 this seems implausible (Gordon, 2017).

To think through the limitations of this analysis, we consider the more general King-Prosser-Rebelo utility function (King et al., 1988) as in Mankiw and Weinzierl (2006) and Kimball and Shapiro (2008):

$$
U=\sum_{t}(1+\rho)^{t} \frac{\left(y_{t} h_{o}\left(\psi^{t}\right)^{1-\phi} e^{(1-\phi) \nu\left(n_{t}\right)}-1\right.}{1-\phi}
$$

Where $\nu\left(n_{t}\right)$ captures the disutility from working, and $\psi$ is (one plus) the rate of hedonic progress, and $\rho$ is the subjective discount rate. Thus, generations' utilities will now depend on both the (total discounted) quality level of their consumption and the unpleasantness of their work as well as their total lifetime real incomes. This opens up two other potential sources of difference across generations. Firstly, discounting means that the shape of the life cycle earnings trajectory (and of $\nu\left(n_{t}\right)$ ) matters. It also means that the (subjective) discount rate itself matters. Secondly, we now allow for the possibility 
Figure 11: Hedonic improvement for total population (log utility)

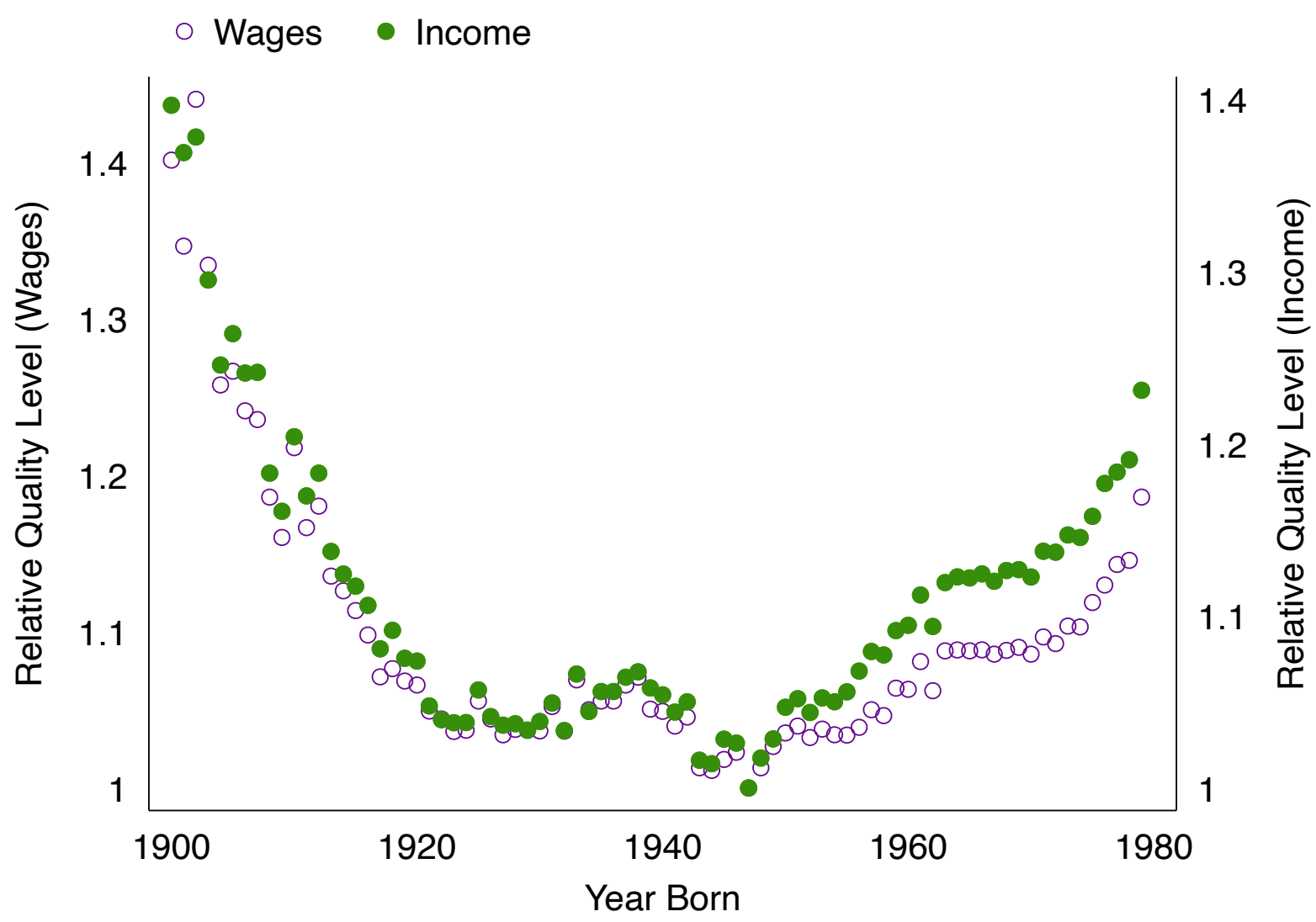

Source: Current Population Survey (CPS)

Notes: Includes the total population, wages and incomes are adjusted for inflation, and individual weights are used.

that that those from later generations may not have consumed more over their lifetime, but may have endured less to get it.

The shape of the earnings trajectory was discussed in Section 2 in which we saw that generations subsequent to the Boomers both had lower average earnings and had to wait longer to attain maximum earnings. Thus, on this basis, and given a positive discount rate, the comparison in Figure 11 will understate the necessary rate of hedonic progress to equalise consumption for those born subsequent to the Baby Boom. On the other hand, increases in life expectancy over the period may reduce discount rates which would offset this.

Thus, if, over their career, the median worker from the Silent Generation endured lower standards of labour protection or the benefits of fewer labour-saving devices, or simply less meaningful work compared to their equivalent from Gen. X, then the welfare comparison in Figure 11 is further complicated. As it will be, if on the other hand, similar jobs today are more stressful or tiring than in the past. 
Such changes over time in the disutility of work are analysed by Kaplan and Schulhofer-Wohl (2018) who use data from the American Time Use Study (ATUS) to compute average worker feelings about their jobs by occupation and then analyse the implications of changes in the occupation structure of the US workforce to back out changes in aggregate feelings about work. As they discuss, in the absence of reliable and comparable historical data on workers' feelings about work, they need to assume that feelings by occupation have been stable overtime. This assumption, will be more plausible in some occupations than others, as some have changed little while others due to improvements in safety practices and technology are likely much better. In Figure 12 we plot for each of the six feelings they consider: Tiredness, Stress, Pain, Meaning, Happiness and Sadness the average of these feelings (for available years) between the ages of 20 and 65 by year of birth. This then is the sum of feelings about each occupation weighted by the lifetime share of that occupation out of total years worked for that birth cohort.

For all six feelings, the results suggest a consistent trend over time. But, these trends are not all in the same direction. Later generations experience more tiredness and more stress over their lifetime. But, one interpretation of the trends in other feelings is that work has become less important as a determinant of worker's feelings. It makes them less happy, but also less sad. It does not provide meaning, but also does not cause them pain. Such conflicting trends precludes an overall judgement about whether the disutility of work has increased or not. But, there is certainly no clear evidence that it has decreased. This in turn suggests that we can rule out changes in $\nu\left(n_{t}\right)$ across generations.

Overall, given this framework and the assumptions contained within we can draw the qualitative conclusions presented in Figure 11.

\section{Conclusion}

In this paper we document how, when comparing one generation to another, the median real wages of American men and women have been declining since the Silent Generation, born between 1925-1945. This is in contrast to consistent output and productivity growth over the same period (Jorgenson et al., 2008, Gordon, 2017). This phenomenon of declining incomes, first documented by Guvenen et al. (2017), is shown to be true conditional on a broad set of controls and allowing for unrestricted heterogeneity across industries. With the exception of the lowest-earning women and non-Whites it is true across the income distribution. It has two key sets of implications. Firstly, this lack of intergenerational progress may, as argued by Friedman (2005), lead to an increasingly challenging environment for democracy. Secondly, given consistent productivity growth it implies that the labour share of income has been falling on a generational basis. We investigate this possibility and show that, 
Figure 12: Disutility of work by year of birth

(a) Tired

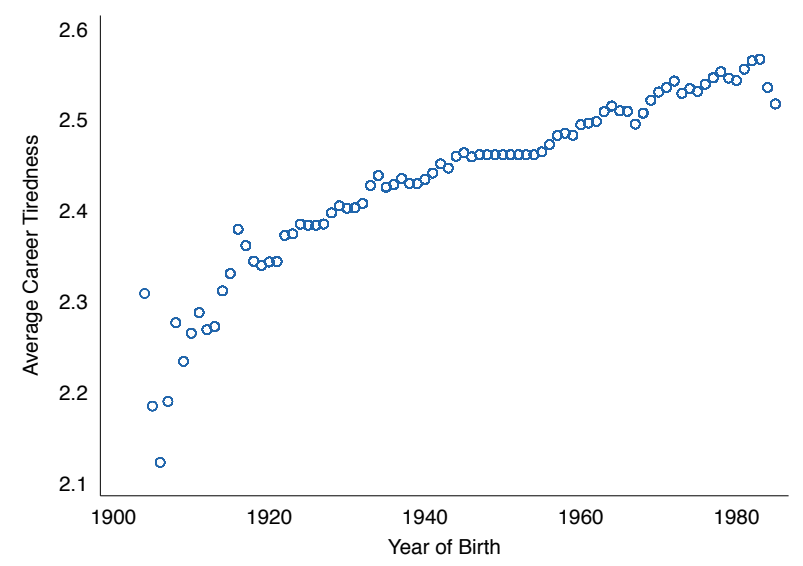

(c) Pain

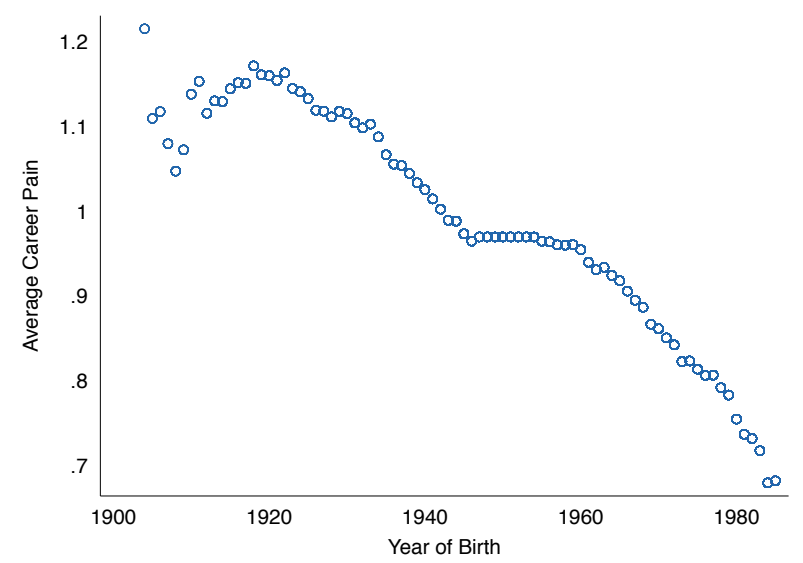

(e) Happiness

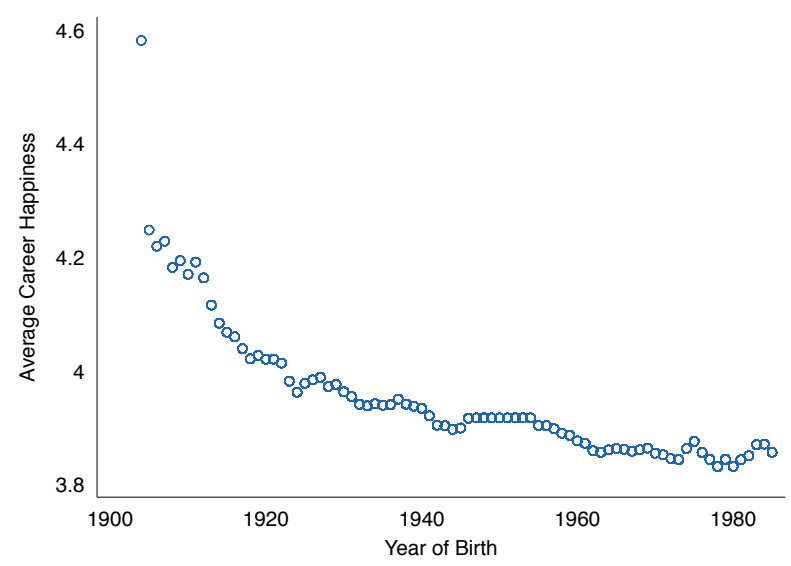

(b) Stressed

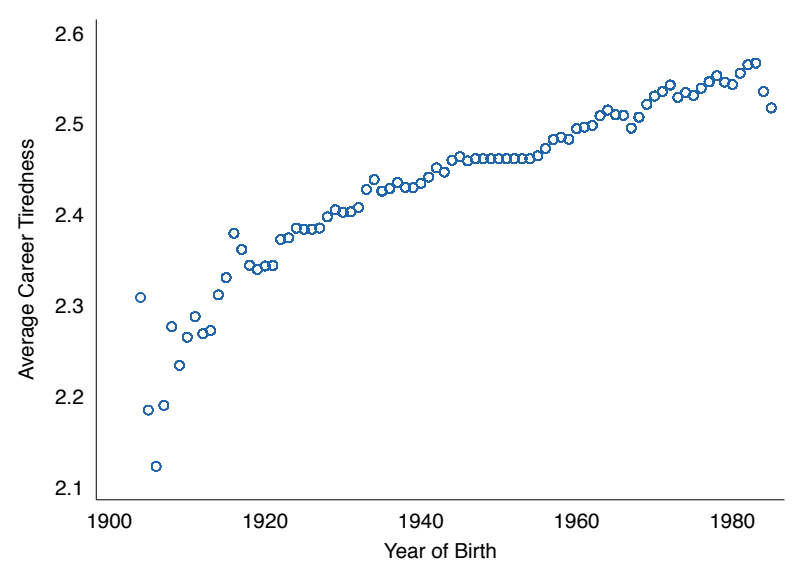

(d) Meaning

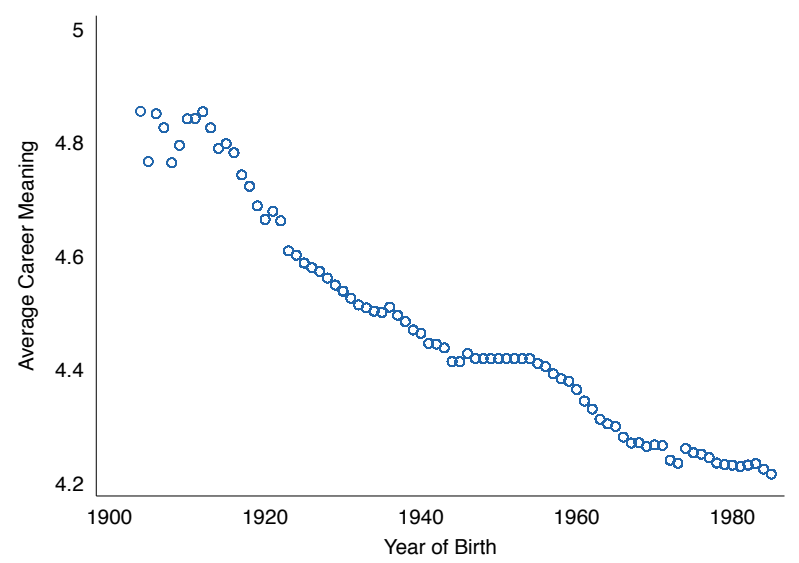

(f) Sadness

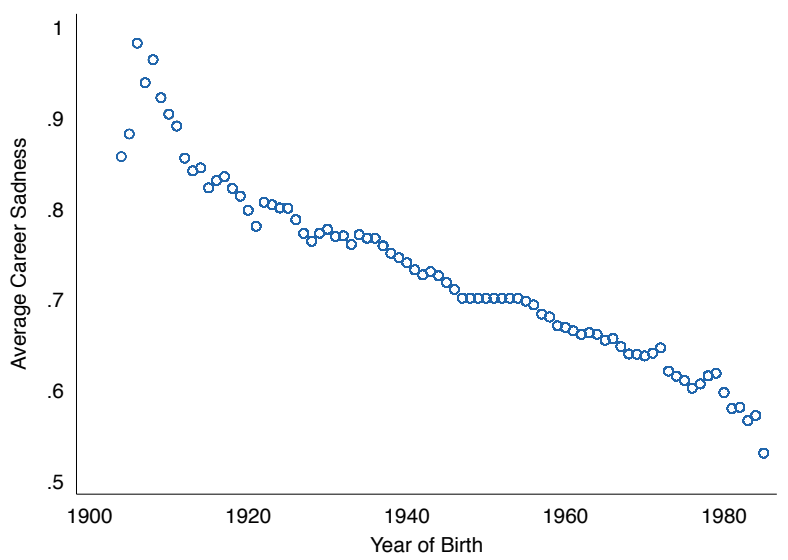

Source: Kaplan and Schulhofer-Wohl (2018) 
within sector and state, and conditional on a range of controls, that the labour share is lower for Gen. X'ers and Millennials.

Of course, to some degree this is implied by the findings of Karabarbounis and Neiman (2014), Piketty (2018), Autor and Salomons (2018), Autor et al. (2020) that the labour share is decreasing, but what is novel is that the labour share is systematically different for workers of different generations, even conditioning on age, year and occupation. What it is that has caused this change is not something this paper speaks to, but we note that the change is consistent across most industries and for all subgroups.

Furthermore, it is not immediately obvious which of the leading explanations such as the rise of 'superstar firms' (Autor et al., 2020), automation Autor and Salomons (2018), the price of investment goods (Karabarbounis and Neiman, 2014), or the rate of productivity growth (Grossman et al., 2018), or the rise of offshoring (Elsby et al., 2013), would predict such large changes between generations, other things equal. Our variance decomposition analysis in Section 4 showed that these changes are of quantitative importance even once we allow for the role of state, industry, education, and demographics. The final part of the paper considers whether hedonic improvements in the quality of goods and services have been sufficiently large to imply improving standards of living across generation. We find that the implied qualitative improvement for consumption to be equalised across generations is around $30 \%$, which is a substantial improvement, but not necessarily an implausible one. 


\section{References}

Abowd, J. M., F. Kramarz, and D. N. Margolis (1999): "High wage workers and high wage firms," Econometrica, 67, 251-333.

Acemoglu, D. And D. Autor (2011): Skills, tasks and technologies: Implications for employment and earnings, vol. 4, Elsevier Inc.

Acemoglu, D. And P. Restrepo (2018): "The Race between Man and Machine: Implications of Technology for Growth, Factor Shares, and Employment," American Economic Review, 108, $1488-1542$.

Autor, D., D. Dorn, And G. Hanson (2019): "When Work Disappears: Manufacturing Decline and the Falling Marriage Market Value of Young Men," American Economic Review: Insights, 1, $161-78$.

Autor, D., D. Dorn, And G. H. Hanson (2013): "The China syndrome: Local labor market effects of import competition in the United States," American Economic Review, 103, 2121-68.

Autor, D., D. Dorn, L. F. Katz, C. Patterson, and J. Van Reenen (2020): "The Fall of the Labor Share and the Rise of Superstar Firms*," The Quarterly Journal of Economics.

Autor, D. And A. Salomons (2018): "Is Automation Labor Share-Displacing? Productivity Growth, Employment, and the Labor Share," Brookings Papers on Economic Activity, 2018, 187.

Black, D. A., N. Kolesnikova, S. G. Sanders, and L. J. Taylor (2013): "The role of location in evaluating racial wage disparity," IZA Journal of Labor Economics.

Bloom, N., R. Sadun, And J. Van Reenen (2012): “Americans Do IT Better: US Multinationals and the Productivity Miracle," American Economic Review, 102, 167-201.

Blundell, R., A. Bozio, and G. Laroque (2011): "Labor supply and the extensive margin," American Economic Review, 101, 482-486.

Borella, M., M. De Nardi, and F. Yang (2017): "The Effects of Marriage-Related Taxes and Social Security Benefits," Working Paper 23972, National Bureau of Economic Research.

Borella, M., M. D. NARdi, And F. YAng (2019): "The Lost Ones : the Opportunities and Outcomes of Non-College Educated Americans Born in the 1960s," NBER Macroeconomics Annual. 
Burstein, A., E. Morales, And J. Vogel (2019): "Changes in Between-Group Inequality: Computers, Occupations, and International Trade," American Economic Journal: Macroeconomics, 11, $348-400$.

Böckerman, P. AND M. Maliranta (2011): "Globalization, creative destruction, and labour share change: evidence on the determinants and mechanisms from longitudinal plant-level data," Oxford Economic Papers, 64, 259-280.

Case, A. And A. Deaton (2015): "Rising morbidity and mortality in midlife among white nonHispanic Americans in the 21st century," Proceedings of the National Academy of Sciences, 112, $15078-15083$.

Chetty, R., N. Hendren, P. Kline, E. Saez, And N. Turner (2014): "Is the United States still a land of opportunity? Recent trends in intergenerational mobility," American Economic Review, $104,141-47$.

Chetverikov, D., B. Larsen, And C. Palmer (2016): "IV Quantile Regression for Group-Level Treatments, With an Application to the Distributional Effects of Trade," Econometrica, 84, 809-833.

Elsby, M., B. HobiJn, And A. Sahin (2013): "The Decline of the U.S. Labor Share," Brookings Papers on Economic Activity, 44, 1-63.

Friedman, B. M. (2005): The Moral Consequences of Economic Growth, New York: Alfred A. Knopf.

FrYeR, R. (2011): "Racial inequality in the 21st century: The declining significance of discrimination," in Handbook of Labor Economics, Elsevier, vol. 4, 855-971.

Gabaix, X., J.-M. Lasry, P.-L. Lions, And B. Moll (2016): "The Dynamics of Inequality," Econometrica, 84, 2071-2111.

Gibbons, S., H. G. Overman, and P. Pelkonen (2014): "Area disparities in Britain: Understanding the contribution of people vs. place through variance decompositions," Oxford Bulletin of Economics and Statistics, 76, 745-763.

Goldin, C. (2014): "A Grand Gender Convergence: Its Last Chapter," American Economic Review, 104, 1091-1119.

Gordon, R. J. (2017): The rise and fall of American growth: The US standard of living since the civil war, vol. 70, Princeton University Press. 
Grossman, G., E. Helpman, E. Oberfield, and T. Sampson (2018): "The Productivity Slowdown and the Declining Labor Share," 2018 Meeting Papers 169, Society for Economic Dynamics.

Guvenen, F., G. Kaplan, J. Song, And J. Weidner (2017): "Lifetime Incomes in the United States Over Six Decades," .

Jones, C. I. And P. J. Klenow (2016): "Beyond GDP? Welfare across countries and time," American Economic Review, 106, 2426-57.

Jorgenson, D. W., M. S. Ho, And K. J. Stiroh (2008): "A retrospective look at the US productivity growth resurgence," Journal of Economic Perspectives, 22, 3-24.

Kaplan, G. And S. Schulhofer-Wohl (2018): "The Changing (Dis-)utility of Work," Journal of Economic Perspectives, 32, 239-58.

Karabarbounis, L. And B. Neiman (2014): "The Global Decline of the Labor Share," The Quarterly Journal of Economics, 129, 61-103.

Kimball, M. S. and M. D. Shapiro (2008): "Labor Supply: Are the Income and Substitution Effects Both Large or Both Small?" Working Paper 14208, National Bureau of Economic Research.

King, R. G., C. I. Plosser, And S. T. Rebelo (1988): "Production, growth and business cycles: I. The basic neoclassical model," Journal of Monetary Economics, 21, 195-232.

Kopczuk, W., E. Saez, And J. Song (2010): "Earnings Inequality and Mobility in the United States: Evidence from Social Security Data since 1937," The Quarterly Journal of Economics, 125, $91-128$.

Lang, K. And M. Manove (2011): "Education and Labor Market Discrimination," American Economic Review, 101, 1467-1496.

Mankiw, N. G. AND M. Weinzierl (2006): "Dynamic scoring: a back-of-the-envelope guide," Journal of Public Economics, 90, 1415-1433.

Manning, A. (2011): "Imperfect Competition in the Labor Market," in Handbook of Labor Economics, ed. by O. Ashenfelter and D. Card, Elsevier, vol. 4 of Handbook of Labor Economics, chap. 11, 973-1041.

MCDAnIEL, C. (2011): "Forces shaping hours worked in the OECD, 1960-2004," American Economic Journal: Macroeconomics, 3, 27-52. 
Philippon, T. And A. Reshef (2012): "Wages and Human Capital in the U.S. Finance Industry: 1909-2006," The Quarterly Journal of Economics, 127, 1551-1609.

(2013): "An international look at the growth of modern finance," Journal of Economic Perspectives, 27, 73-96.

PiketTy, T. (2018): Capital in the 21st Century, Routledge.

Piketty, T. and E. Saez (2003): "Income inequality in the United States, 1913-1998," The Quarterly Journal of Economics, 118, 1-41.

SAez, E. AND G. Zucman (2016): "Wealth inequality in the United States since 1913: Evidence from capitalized income tax data," The Quarterly Journal of Economics, 131, 519-578.

Song, J., D. J. Price, F. Guvenen, N. Bloom, and T. von Wachter (2018): "Firming Up Inequality," The Quarterly Journal of Economics, 134, 1-50. 


\section{A Data appendix}

\section{A.1 Current Population Survey (CPS)}

The CPS is individual micro-level data which is available from 1962 to 2018 and with the sample weights it is representative of the US population each year. The core of our analysis is at the cohort or generation level. These are defined by the year of birth of individuals, which we work out from year of survey and their age. The classifications of which are presented in Table A.1. The first column refers to year born with the corresponding definition in the right column.

Table A.1: Different birth cohorts.

\begin{tabular}{l|l}
\hline Year born & Birth cohort \\
\hline $2000-$ Present & Generation Z \\
$1980-1999$ & Millennials (Gen. Y) \\
$1965-1979$ & Generation X (Gen. X) \\
$1946-1964$ & Baby Boomers (Boomers) \\
$1925-1945$ & Silent Generation \\
\hline
\end{tabular}

\section{A.2 Summary of the data}

In Table A.2, summary statistics for the CPS are presented, both for each of our cohorts and for the total sample. All monetary amounts are adjusted for inflation using Consumer Price Index (CPI) with 1999 as the base year. We make a number of sample restrictions. Firstly, we drop individuals who are self-employed, in education or working for the government. And secondly, we consider only individuals between the ages of 23 and 65 . Further to this, we also drop observations where the annual earnings do not meet the minimum income threshold. Following Guvenen et al. (2017), we define the threshold as 520 hours times half the federal minimum wage for that year. Lastly, all results are produced using the probability weights provided by the CPS.

We calculate the hourly wage as the income from labour divided by the usual hours worked per week last year times by the 52 weeks of the year. Demographic variables are coded naturally. Our preferred occupation controls are six broad occupation categories, aggregated from the 389 categories included in the CPS. Our results are robust to the inclusion of finer occupation codes.

\section{A.3 Economic Census}

The Economic Census is available every five years, beginning in 1977. The survey contains data regarding eight primary industries; Retail Trade, Wholesale Trade, Service, Finance, Construction, Manufacturing, and Utilities and Transport. The data coverage varies depending on the wave of the survey and by geographic level. 
Table A.2: Summary statistics (CPS), total and by cohort

\begin{tabular}{|c|c|c|c|c|c|c|c|c|c|c|}
\hline & \multicolumn{2}{|c|}{ Total } & \multicolumn{2}{|c|}{ Silent } & \multicolumn{2}{|c|}{ Boomer's } & \multicolumn{2}{|c|}{ Gen. $X$} & \multicolumn{2}{|c|}{ Millennials } \\
\hline & Mean & Std.Dev. & Mean & Std.Dev. & Mean & Std.Dev. & Mean & Std.Dev. & Mean & Std.Dev. \\
\hline \multicolumn{11}{|l|}{ Demographics } \\
\hline Age & 40.07 & 11.35 & 44.16 & 10.78 & 40.95 & 11.01 & 34.45 & 7.29 & 27.60 & 3.58 \\
\hline Female & 0.44 & 0.50 & 0.41 & 0.49 & 0.46 & 0.50 & 0.45 & 0.50 & 0.46 & 0.50 \\
\hline Married & 0.65 & 0.48 & 0.77 & 0.42 & 0.66 & 0.47 & 0.58 & 0.49 & 0.39 & 0.49 \\
\hline Separated/Divorced & 0.13 & 0.34 & 0.13 & 0.33 & 0.16 & 0.37 & 0.13 & 0.34 & 0.07 & 0.25 \\
\hline White & 0.84 & 0.37 & 0.88 & 0.33 & 0.85 & 0.36 & 0.80 & 0.40 & 0.77 & 0.42 \\
\hline African American & 0.11 & 0.31 & 0.10 & 0.30 & 0.11 & 0.31 & 0.12 & 0.33 & 0.13 & 0.33 \\
\hline Hispanic & 0.19 & 0.39 & 0.25 & 0.43 & 0.09 & 0.29 & 0.17 & 0.38 & 0.21 & 0.40 \\
\hline \multicolumn{11}{|l|}{ Education } \\
\hline High School Graduate & 0.69 & 0.46 & 0.43 & 0.49 & 0.76 & 0.43 & 0.88 & 0.32 & 0.91 & 0.28 \\
\hline College & 0.21 & 0.41 & 0.10 & 0.30 & 0.21 & 0.41 & 0.31 & 0.46 & 0.34 & 0.48 \\
\hline \multicolumn{11}{|l|}{ Occupation } \\
\hline Managerial \& Professional Specialty & 0.24 & 0.43 & 0.20 & 0.40 & 0.27 & 0.44 & 0.29 & 0.45 & 0.28 & 0.45 \\
\hline Technical Sales \& Administrative Support & 0.28 & 0.45 & 0.26 & 0.44 & 0.31 & 0.46 & 0.30 & 0.46 & 0.30 & 0.46 \\
\hline Service & 0.11 & 0.32 & 0.09 & 0.29 & 0.11 & 0.31 & 0.13 & 0.34 & 0.17 & 0.37 \\
\hline Farming, Forestry \& Fishing & 0.02 & 0.13 & 0.01 & 0.12 & 0.02 & 0.13 & 0.02 & 0.14 & 0.02 & 0.15 \\
\hline Precision Production, Craft \& Repair & 0.12 & 0.33 & 0.13 & 0.33 & 0.13 & 0.33 & 0.12 & 0.32 & 0.10 & 0.31 \\
\hline Operators, Fabricators \& Labourers & 0.17 & 0.38 & 0.20 & 0.40 & 0.18 & 0.38 & 0.15 & 0.36 & 0.13 & 0.33 \\
\hline \multicolumn{11}{|l|}{ Labour Market } \\
\hline Hours Worked per Week & 40.50 & 9.89 & 39.91 & 10.22 & 40.83 & 9.91 & 40.80 & 9.62 & 39.61 & 9.63 \\
\hline Hourly Wage & 15.66 & 19.80 & 15.70 & 15.71 & 16.11 & 20.10 & 15.79 & 20.04 & 13.55 & 24.33 \\
\hline Labour Income & 33,079 & 34,295 & 32,404 & 27,000 & 34,666 & 36,953 & 34,083 & 38,834 & 28,038 & 33,025 \\
\hline Total Income & 56,395 & $10,836,307$ & 62,077 & $12,239,682$ & 37,061 & 38,964 & 35,717 & 40,186 & 29,281 & 33,765 \\
\hline Observations & $2,593,069$ & & 573,242 & & $1,033,834$ & & 572,671 & & 195,737 & \\
\hline
\end{tabular}

Note: The sample used includes only individuals who are in employment, and are not self employed or working for the government. We include those between the ages of 23 and 65 . We drop observations which do not meet the minimum income threshold as described in the main text. Income and wage variables are in 1999 US dollars. Summary statistics are produced using the individual weights from the CPS.

There are a number of series which are available across all years and industries: geographic series, non-employer statistics and subject series are the main available data series. We predominately be use the geographic series, which contains detailed information about establishments which have payroll. Data is organised by type of business and geographic areas; the United States, States, Metropolitan Areas, Counties and Places. The earlier data was aggregated mostly to broad industry levels, for this reason we also use broad industry codes to maximise the amount of data available. Similarly, we use state level data, going to metropolitan statistical area (MSA) leads to a number of cells to be suppressed, hence losing a number of observations. So to maximise the available sample, we use state level, broad industry groupings.

Where we have observations, we can know the number of establishments, annual payroll in $\$ 1000$, value of first quarter payroll and value of sales and receipts. It is important to note that not all industries within a particular sector are covered by the economic census. These include; schools (all levels), the US Postal Service, public administration, private households and membership organisations. Moreover, not all industries are represented in all years. For example, we only have data on Utilities and Transportation from 1992. The only industries which we observe in each wave of the Economic Census are Retail, Services and Wholesale Trade. Further to this, only value added is available for the manufacturing industry in 1982 and 1987. 


\section{A.3.1 Creating consistent industry codes}

The CPS contains consistent industry codes from 1968 - present using the 1990 census classification. However, the Economic Census makes use of Standard Industrial Classification of Economic Activities (SIC) codes and then later North American Industry Classification System (NAICS) coding, see Table A.3 for a summary of the industry codes which are used when. We address this, using NAICS cross-walks to create a set of consistent NAICS codes. ${ }^{18}$ We then use the cross-walks of Autor et al. (2013) and Autor et al. (2019) to create the consistent industry codes across SIC and match our data sets using a combination of SIC and NAICs codes. Using this consistent coding we then match the census data to the CPS data using year, state and industry identifiers

Table A.3: Industry coding by year in the economic census.

\begin{tabular}{l|l}
\hline Year & Industry code \\
\hline $1977-1982$ & 1972 SIC Code \\
$1987-1997$ & 1987 SIC Code \\
$1997-2012$ & Year Specific NAICS Code \\
\hline
\end{tabular}

Not all levels of disaggregation in the industry codes are available every year. So working with a more disaggregated industry classification implies truncating the sample. Notably, 1977 and 1982 contain only the most aggregating industry coding and as such as we lose these years of observations if we work with the disaggregated classification.

\section{Pre-1997 data}

Here, the industry coding used is not consistent and the available granularity of the data is year and industry dependant. We have in the two-digit industry code the sales and number of establishments, however we do not have number of employees or the payroll information. In some cases the best we can do is to aggregate at the industry level only. Therefore, to make use of this data we take the aggregate state and 1-digit SIC level data.

\section{Post-1997 data}

The raw economic census data provided breakdowns from two-digit codes up to six-digit codes for a range of industries. For the industries where the broadest classification was three digit, we summed across to collapse to a two-digit industry code which could be merged with the 1990 industry codes. We can then in turn collapse to the 1 digit broad industry code for our main analyses.

\footnotetext{
${ }^{18}$ See https://www.census.gov/eos/www/naics/concordances/concordances.html for NAICS cross-walks
} 


\section{A.4 Merging the data}

We aggregate to various industry and geographic levels to merge with the industry-level data. This is because of a limitation of the data means that finer industry categories or using Metropolitan Statistical Area (MSA) leads to a large amount of suppressed values in order to protect identity of the firms, for example. As a result we merge using the state and broad industry category.

These are sufficient to merge with the available firm-level microdata. In the CPS, around $4.4 \%$ of the observations have an unidentified state. Additionally, industries are identified using SIC codes in the CPS data.

As discussed, the Economic Census does not cover the universe of industries and occupations. As a result, for the purpose of merging the two data sets, we drop from our CPS sample those industries which are not covered by the Census. This equates to dropping just over $10 \%$ of the observations. The industries which are excluded are presented below in Table A.4.

Table A.4: Summary of excluded industries

\begin{tabular}{l|l}
\hline 1990 Census industry & Title \\
\hline $10-32$ & Agriculture, Forestry \& Fisheries \\
400 & Railroads \\
412 & US Postal Service \\
710 & Security, commodity brokerage, and investment companies \\
711 & Insurance \\
873 & Labour Unions \\
880 & Religious Organisations \\
881 & Membership Organisations \\
$>900$ & Public Administration \\
\hline
\end{tabular}

We lose around $5 \%$ of observations each year during the merge. More so in the earlier years as the number of industries which were included was much more limited than in later surveys.

\section{A.5 The National Income and Product Accounts (NIPA)}

The National Product and Income Accounts (NIPA) are provided by the Bureau of Economic Analysis (BEA) and at a much more aggregated level than that of the Economic Census. The NIPA data is produced from a number of sources at a much higher frequency than that of the Economic Census. Moreover, it contains measures of value added for all industries rather than just Manufacturing as in the Economic Census.

The NIPA data also contains more detailed data on employee compensation. They record a main employee compensation variable which is formed of two components which is also included in the data. Firstly, wages and salaries which we refer to as the payroll amount, which contains any payment to 
Figure A.1: Labour share over time for different industries: Payroll to value added ratio.
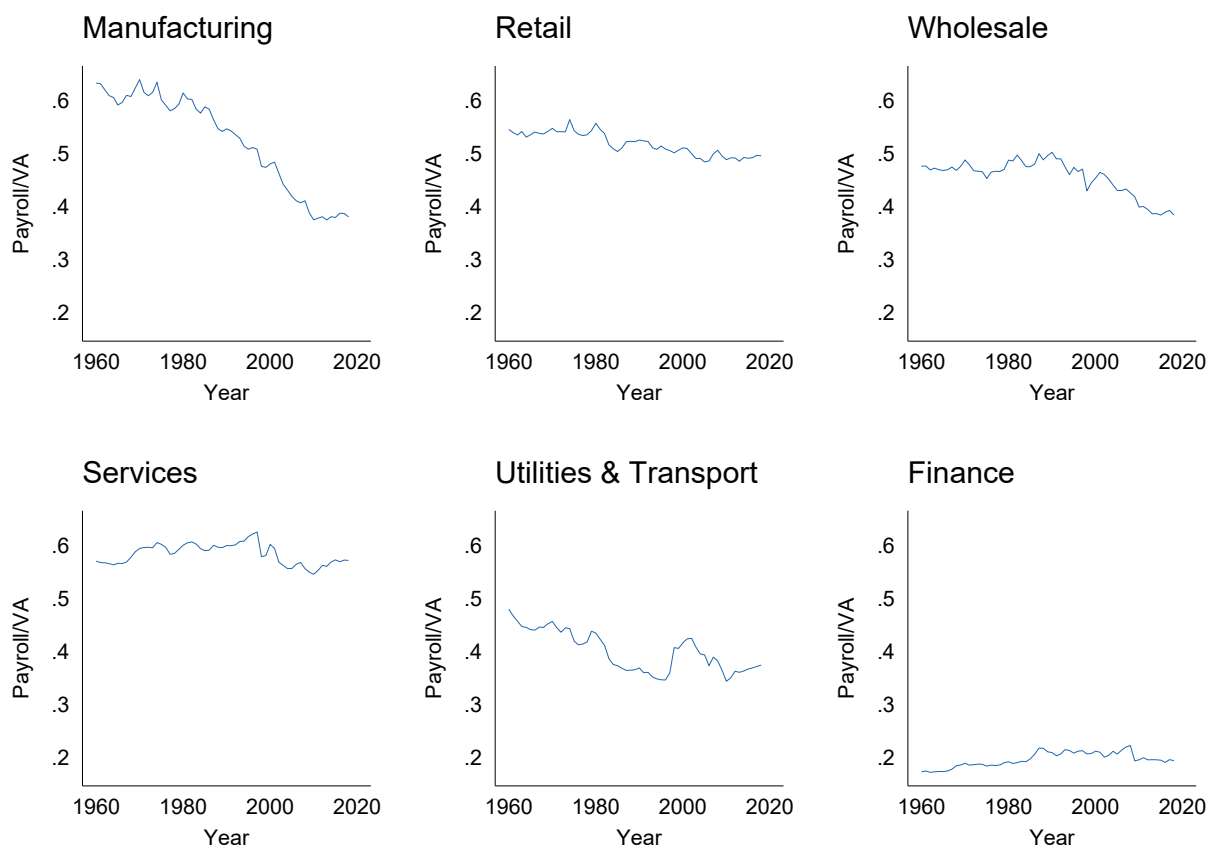

Source: National Income and Product Accounts (NIPA)

Notes:Replication of the labour share calculations using NIPA data as seen in the appendix of Autor et al. (2020), however extending the years considered.

the worker including tips and bonuses and other employee contributions. The second component is supplements to wages and salaries, this includes additional fringe benefits of employment, such as employer contribution to pension and insurance funds, and the employer contribution to Government social security. Furthermore, NIPA contains value added for all industries included, however not sales. The closest proxy to this is what they refer to as gross output which is the value of sales or receipts. Alternatively, the contribution to GDP of each industry in a state is also available.

One key difference between the NIPA data and that in the economic census is how it classifies firms which operate in different industries. For example, retail firms who also have manufacturing operations will only have data captured in one of the sectors, even though they operate in multiple ones. Another thing to keep in mind when comparing the NIPA to Economic Census is that in the Economic Census a number of sub-industries are excluded. This is not the case with the NIPA data.

Below in Figure A.1, we recreate the payroll to value added for six industries as is presented in the appendix of Autor et al. (2020), however extending the years considered to take advantage of the time series available. We produce the same graph in Figure A.2, however using different measures for labour share given the different variables available in the NIPA data.

In looking at Figure A.2 it is evident that the value of the labour share can depend quite a lot on how it is defined. The solid blue line is the payroll over value added; the traditional definition. 
Figure A.2: Different ways to measure labour share in NIPA

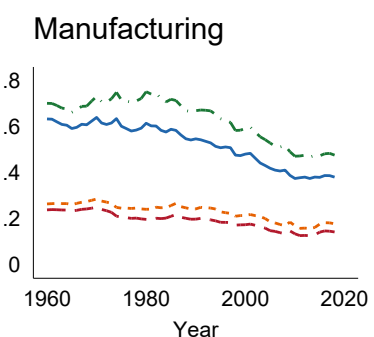

Services

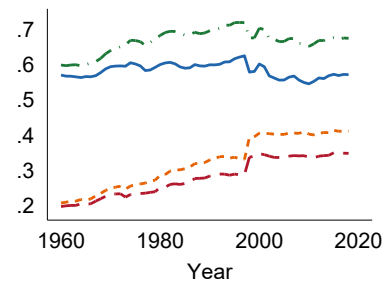

Retail

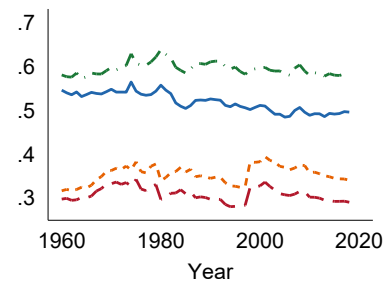

Utilities \& Transport

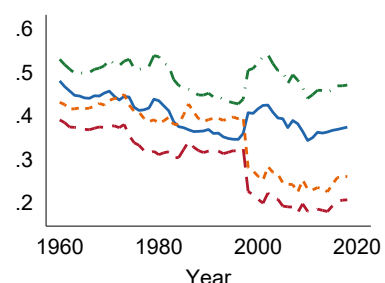

Wholesale

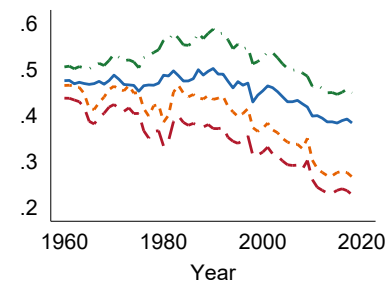

Finance

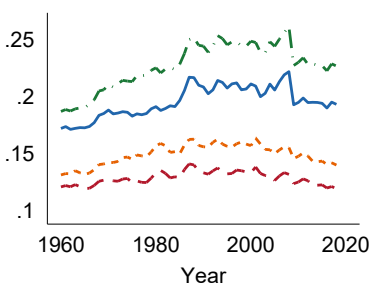

$$
\begin{array}{ll}
\text { - Payroll/VA } & \text {-. Payroll/Sales } \\
\text {-. Compensation/VA } & =. \text { Compensation/Sales }
\end{array}
$$

Source: National Income and Product Accounts (NIPA)

Notes: Each panel shows the labour share over time using the different definitions available in the NIPA data. Sales refers to the gross output. Payroll refers to wages and salaries only, whilst compensation includes this in addition to other employee benefits. VA is the value added.

However, in the Economic Census, value added is not available so we use the payroll to sales ratio. In NIPA, annual value of sales is not available so the closest measure they have is the gross output. This proxy payroll to sales ratio using NIPA is the red dashed line in Figure A.2. This gives a lower value of the labour share for each industry at each point in time.

Looking at the results by Autor et al. (2020) they document a number of differences between the NIPA and the Economic Census, which we should also bear in mind when looking at our results. They find that the are difference in the reported labour share by industry depending on which data is used. They find this is likely due to difference in the sales and gross output variables whilst payroll seems to reflect similar trends.

More concretely, they document that for Wholesale Trade and Finance the Economic Census overstates the labour share compared to the NIPA data, while for Services, and Utilities and Transportation the economic census gives lower estimates of the labour share. Manufacturing and Retail appear to offer similar trends.

\section{Trends by generation}

Using the various measures of labour share plotted above, we can recreate the labour share experienced at each age by generation by weighting the labour share. These results are again using the aggregate 
Figure A.3: Labour share by generation and by age using NIPA (Payroll/Sales)
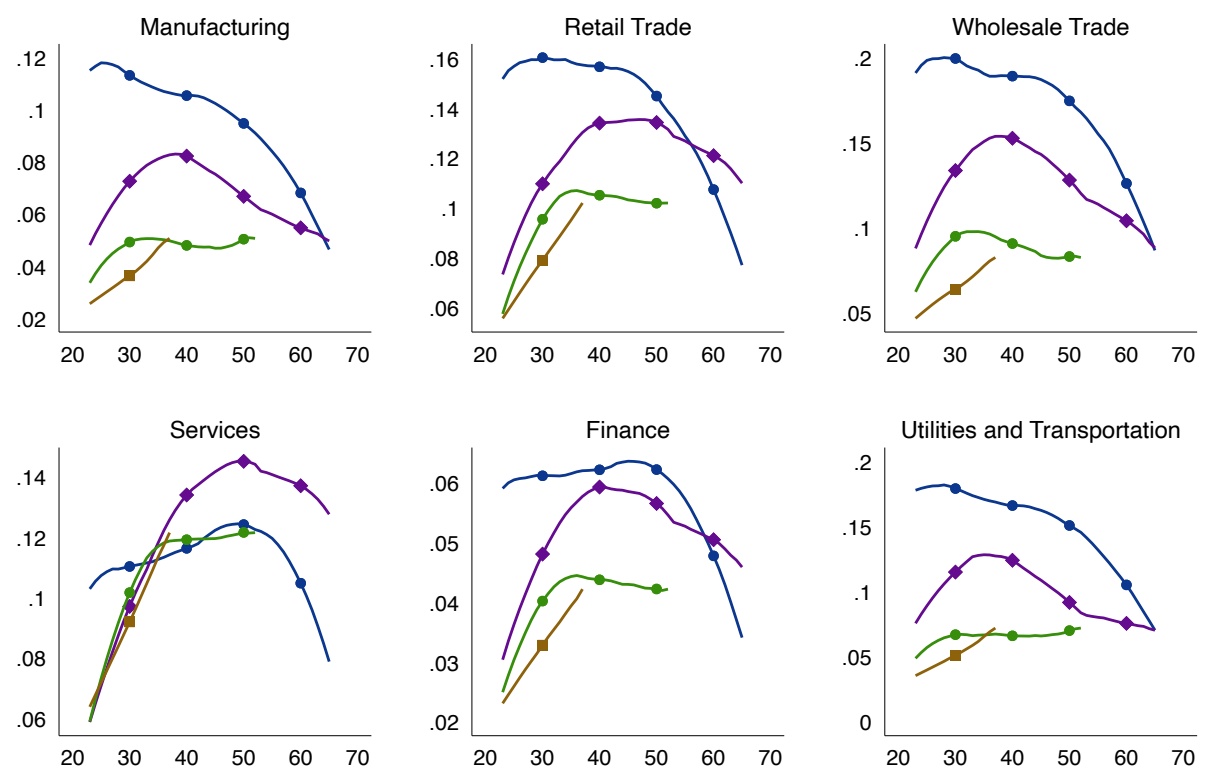

- Silent

Boomers

$\Delta$ Gen. X

Millennials

Source: National Income and Produce Accounts (NIPA) \& Current Population Survey (CPS)

Notes: Data is merged at the year, state and one-digit industry level as described in Appendix A. The labour share is calculated as described in Section 3.1.

national data by year from NIPA. We see patterns which are similar to what we observe with the economic census. A clear dominance in the share of the labour share by older generations compared to their younger counterparts. 


\section{B Additional results}

Figure B.1: Percentiles of the earnings distribution by year

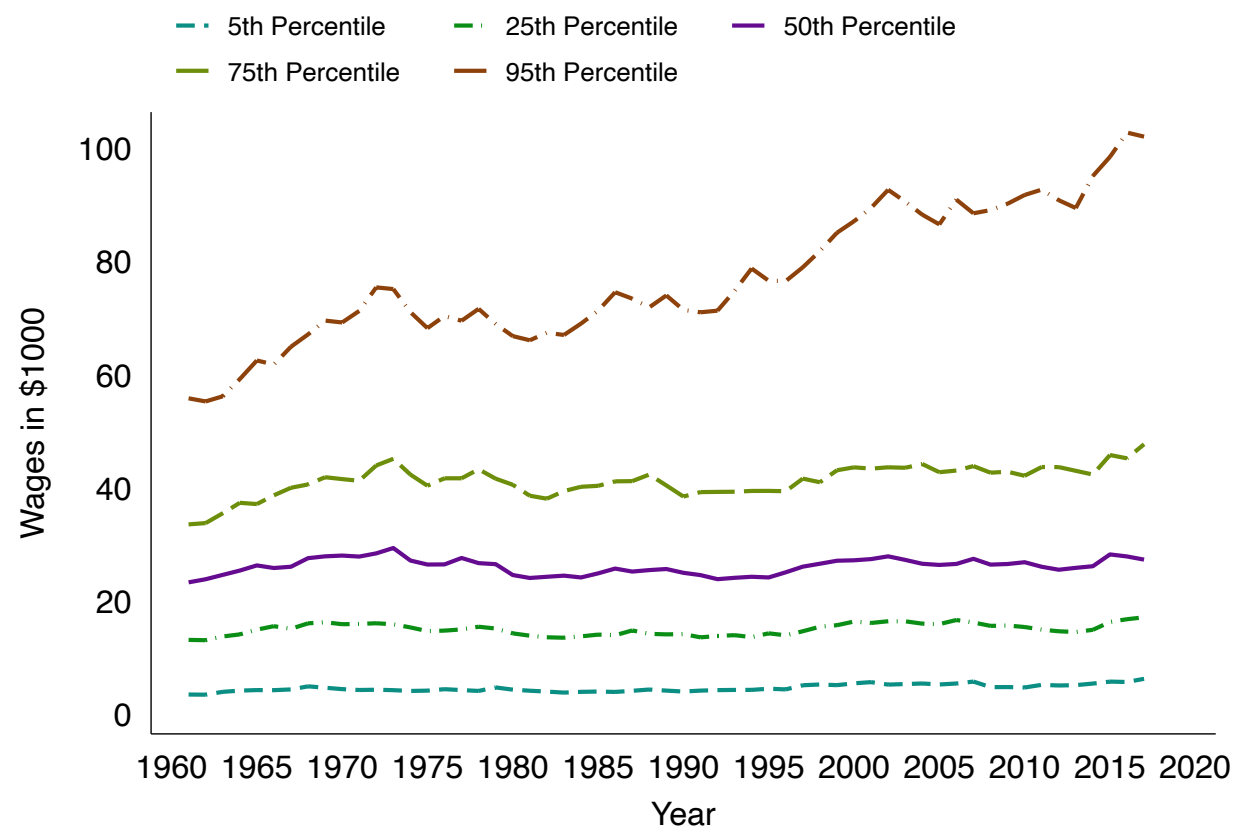

Source: Current Population Survey (CPS)

Notes: Includes the total population, wages are adjusted for inflation, and individual weights are used. The vertical axis is median real income in $\$ 1000$, measured in 1999 dollars. 
Figure B.2: Maximum Median Income (in $\$ 1000$ ) by Year born and the Age which it was reached.
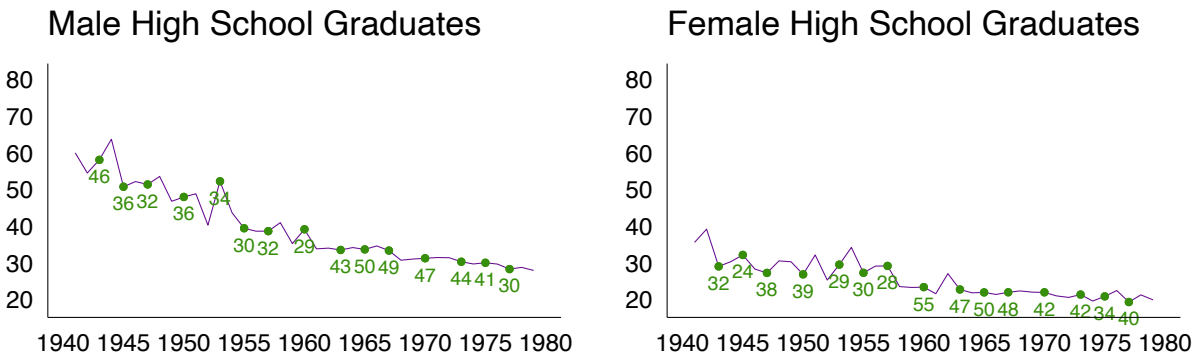

\section{Males with College}

\section{Females with College}
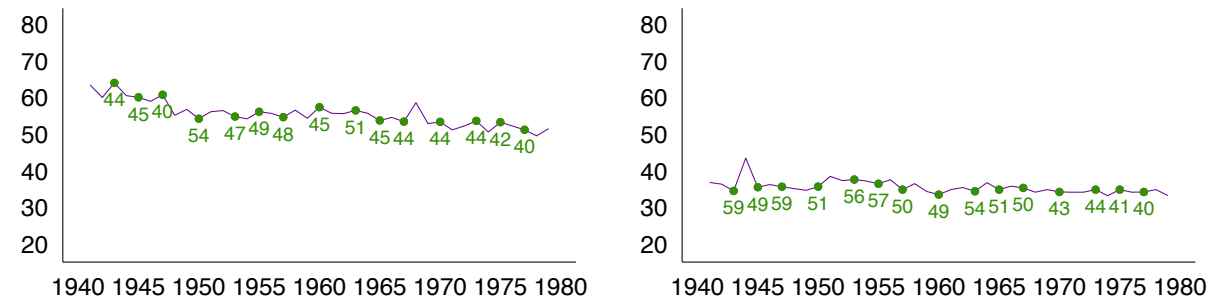

\section{- Age Maximum Median Income Reached}

Source: Current Population Survey (CPS)

Notes: Includes the total population, Income is adjusted for inflation, and individual weights are used. The vertical axis is income in $\$ 1000$. The line is the maximum median income by each year born and the label refers to the age when this maximum median income was achieved.

Figure B.3: Median Income (in \$1000) for each Generation over time
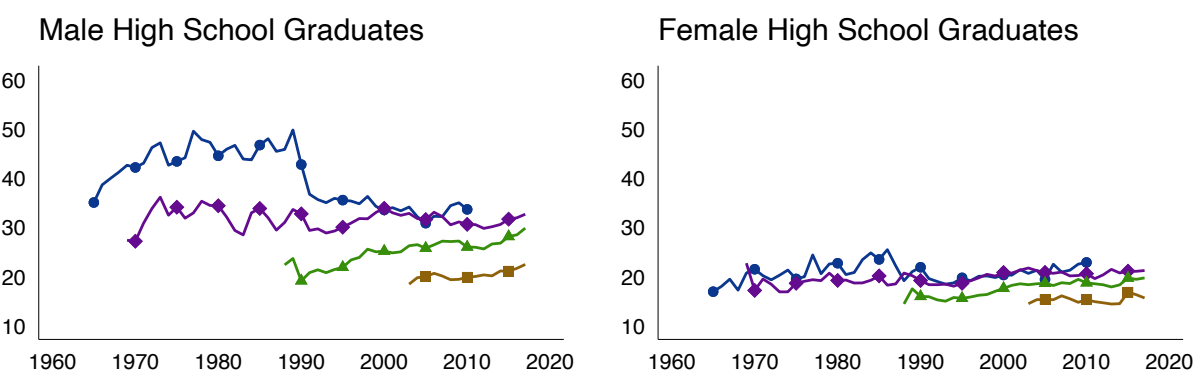

$$
\text { Males with College }
$$

Females with College
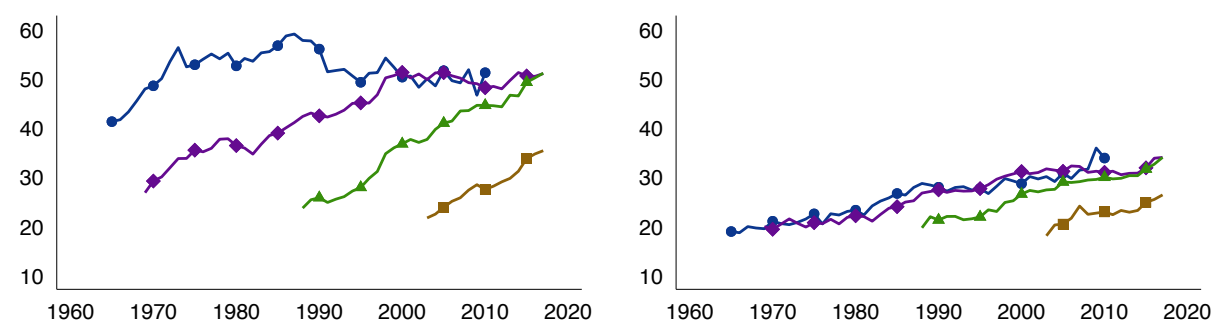

- Silent

Boomers

Gen. X

- Millennials

Source: Current Population Survey (CPS)

Notes: Includes the total population, wages are adjusted for inflation, and individual weights are used. 'some College' includes those who attended college but didn't graduate, those did graduate, and those who have an advanced degree. The vertical axis is median real income in $\$ 1000$, measured in 1999 dollars. 
Figure B.4: Hours worked by generation over the life cycle
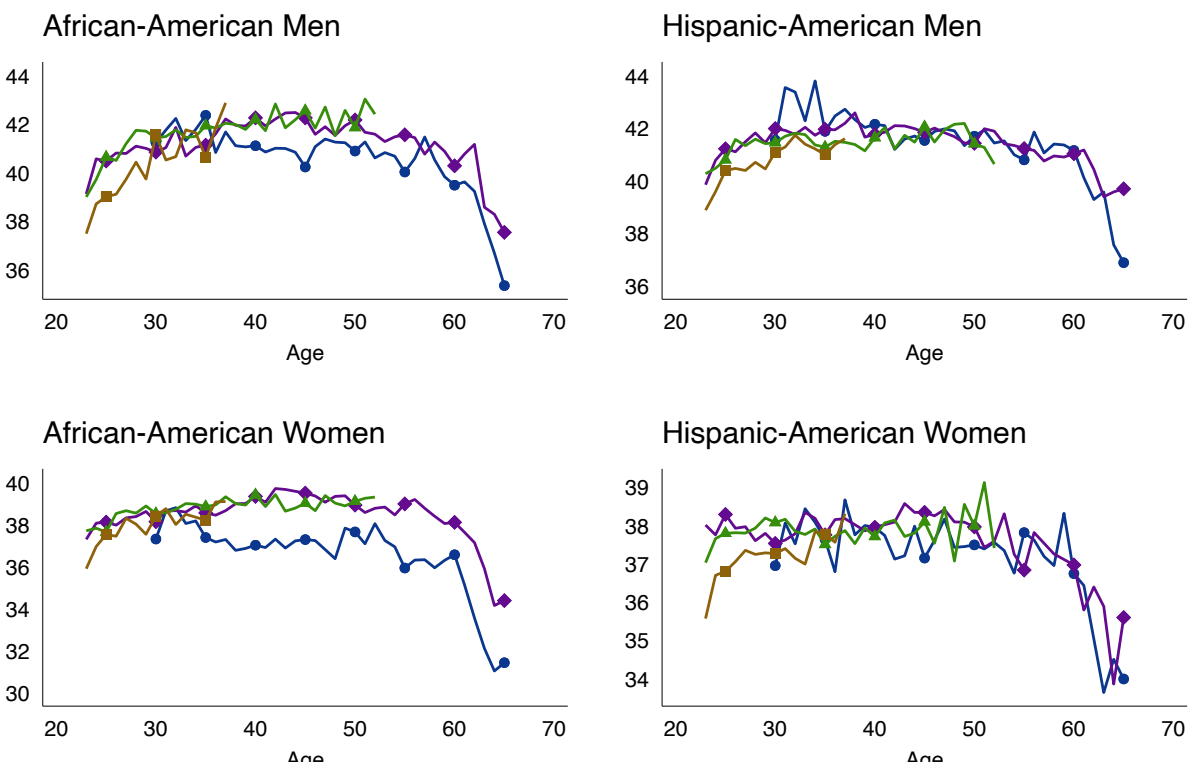

Hispanic-American Women

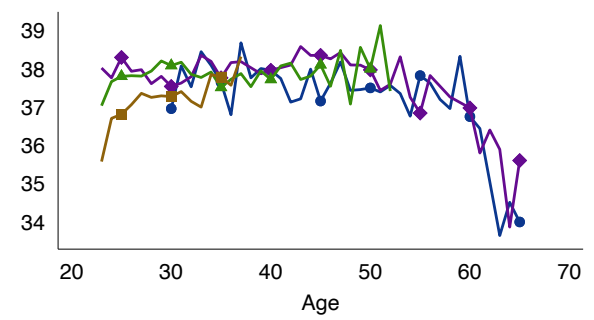

- Silent $\diamond$ Boomers

A Gen. X Millennials

Source: Current Population Survey (CPS)

Notes: Includes the total population, wages are adjusted for inflation, and individual weights are used. The vertical axis is usual hours worker per week. 


\section{B.1 Full regression tables}

Table B.1: Generational differences in real wages by industry: Unconditional results

\begin{tabular}{|c|c|c|c|c|c|c|c|c|}
\hline & $\begin{array}{c}(1) \\
\text { Retail } \\
\beta / \mathrm{SE}\end{array}$ & $\begin{array}{c}(2) \\
\text { Wholesale } \\
\beta / \mathrm{SE}\end{array}$ & $\begin{array}{c}(3) \\
\text { Services } \\
\beta / \mathrm{SE}\end{array}$ & $\begin{array}{c}(4) \\
\text { Finance } \\
\beta / \mathrm{SE}\end{array}$ & $\begin{array}{c}(5) \\
\text { Utilities } \\
\beta / \mathrm{SE}\end{array}$ & $\begin{array}{c}(6) \\
\text { Manufacturing } \\
\beta / \mathrm{SE}\end{array}$ & $\begin{array}{c}(7) \\
\text { Construction } \\
\beta / \mathrm{SE}\end{array}$ & $\begin{array}{c}(8) \\
\text { Mining } \\
\beta / \mathrm{SE}\end{array}$ \\
\hline Baby Boomers & $\begin{array}{l}0.112^{* * *} \\
(0.013)\end{array}$ & $\begin{array}{c}0.010 \\
(0.020)\end{array}$ & $\begin{array}{l}0.186^{* * *} \\
(0.009)\end{array}$ & $\begin{array}{l}0.187^{* * *} \\
(0.031)\end{array}$ & $\begin{array}{l}0.101^{* * * *} \\
(0.023)\end{array}$ & $\begin{array}{l}-0.019^{* *} \\
(0.008)\end{array}$ & $\begin{array}{l}-0.064^{* * * *} \\
(0.017)\end{array}$ & $\begin{array}{l}-0.065 \\
(0.054)\end{array}$ \\
\hline Gen. X. & $\begin{array}{l}0.059^{* * *} \\
(0.013)\end{array}$ & $\begin{array}{l}-0.058^{* * *} \\
(0.022)\end{array}$ & $\begin{array}{l}0.205^{* * *} \\
(0.010)\end{array}$ & $\begin{array}{l}0.135^{* * *} \\
(0.032)\end{array}$ & $\begin{array}{l}-0.078^{* * *} \\
(0.024)\end{array}$ & $\begin{array}{l}-0.091^{* * *} \\
(0.010)\end{array}$ & $\begin{array}{l}-0.121^{* * *} \\
(0.018)\end{array}$ & $\begin{array}{l}-0.160^{* * *} \\
(0.059)\end{array}$ \\
\hline Millennials & $\begin{array}{l}-0.111^{* * *} \\
(0.016)\end{array}$ & $\begin{array}{l}-0.279^{* * *} \\
(0.038)\end{array}$ & $\begin{array}{l}0.048^{* * * *} \\
(0.013)\end{array}$ & $\begin{array}{l}-0.023 \\
(0.037)\end{array}$ & $\begin{array}{l}-0.301^{* * *} \\
(0.031)\end{array}$ & $\begin{array}{l}-0.259^{* * *} \\
(0.018)\end{array}$ & $\begin{array}{l}-0.268^{* * * *} \\
(0.024)\end{array}$ & $\begin{array}{l}-0.090 \\
(0.082)\end{array}$ \\
\hline Constant & $\begin{array}{l}9.661^{* * *} \\
(0.011)\end{array}$ & $\begin{array}{l}10.300^{* * *} \\
(0.017)\end{array}$ & $\begin{array}{l}9.845^{* * *} \\
(0.008)\end{array}$ & $\begin{array}{l}10.127^{* * *} \\
(0.028)\end{array}$ & $\begin{array}{l}10.319^{* * *} \\
(0.021)\end{array}$ & $\begin{array}{l}10.295^{* * *} \\
(0.007)\end{array}$ & $\begin{array}{l}10.173^{* * *} \\
(0.015)\end{array}$ & $\begin{array}{l}10.631^{* * *} \\
(0.050)\end{array}$ \\
\hline Observations & 57739 & 14158 & 120231 & 13257 & 20872 & 73359 & 27138 & 3187 \\
\hline$R^{2}$ & 0.007 & 0.007 & 0.007 & 0.008 & 0.025 & 0.005 & 0.007 & 0.005 \\
\hline
\end{tabular}

Notes: This table presents estimates of Equation (3), excluding covariates and fixed effects. The dependent variable is $\log$ wages. The specification estimated is: $\log w_{j, t}^{i}=\gamma_{g}^{i}+\varepsilon_{j, t}^{i}$. The data from the CPS and BEA are merged at the state geographic level and one-digit industry code as described in Appendix A. The generation variables are all dummy variables defined on the basis of date of birth, as per Table 1. The omitted category is the Silent Generation. Standard errors are in parenthesis. ${ }^{* *}$ Significant at the $1 \%$ level. ${ }^{* *}$ Significant at the $5 \%$ level. ${ }^{*}$ Significant at the $10 \%$ level.

Table B.2: Generational differences in real wages by industry: Including covariates

\begin{tabular}{|c|c|c|c|c|c|c|c|c|}
\hline & $\begin{array}{c}(1) \\
\text { Retail } \\
\beta / \mathrm{SE}\end{array}$ & $\begin{array}{c}(2) \\
\text { Wholesale } \\
\beta / \mathrm{SE}\end{array}$ & $\begin{array}{c}(3) \\
\text { Services } \\
\beta / \mathrm{SE}\end{array}$ & $\begin{array}{c}(4) \\
\text { Finance } \\
\beta / \mathrm{SE}\end{array}$ & $\begin{array}{c}(5) \\
\text { Utilities } \\
\beta / \mathrm{SE}\end{array}$ & $\begin{array}{c}(6) \\
\text { Manufacturing } \\
\beta / \mathrm{SE}\end{array}$ & $\begin{array}{c}(7) \\
\text { Construction } \\
\beta / \mathrm{SE}\end{array}$ & $\begin{array}{c}(8) \\
\text { Mining } \\
\beta / \mathrm{SE}\end{array}$ \\
\hline Baby Boomers & $\begin{array}{l}-0.019 \\
(0.013)\end{array}$ & $\begin{array}{l}-0.079^{* * *} \\
(0.019)\end{array}$ & $\begin{array}{l}0.067^{* * *} \\
(0.009)\end{array}$ & $\begin{array}{l}0.091^{* * * *} \\
(0.034)\end{array}$ & $\begin{array}{c}0.006 \\
(0.024)\end{array}$ & $\begin{array}{l}-0.084^{* * *} \\
(0.008)\end{array}$ & $\begin{array}{l}-0.129^{* * *} \\
(0.018)\end{array}$ & $\begin{array}{l}-0.082^{*} \\
(0.049)\end{array}$ \\
\hline Gen. X. & $\begin{array}{l}-0.048^{* * *} \\
(0.016)\end{array}$ & $\begin{array}{l}-0.113^{* * *} \\
(0.024)\end{array}$ & $\begin{array}{l}0.070^{* * * *} \\
(0.011)\end{array}$ & $\begin{array}{l}0.179^{* * *} \\
(0.040)\end{array}$ & $\begin{array}{l}-0.043 \\
(0.028)\end{array}$ & $\begin{array}{l}-0.181^{* * *} \\
(0.011)\end{array}$ & $\begin{array}{l}-0.160^{* * *} \\
(0.022)\end{array}$ & $\begin{array}{l}-0.126^{*} \\
(0.065)\end{array}$ \\
\hline Millennials & $\begin{array}{l}-0.111^{* * *} \\
(0.020)\end{array}$ & $\begin{array}{l}-0.192^{* * *} \\
(0.040)\end{array}$ & $\begin{array}{l}0.033^{* *} \\
(0.015)\end{array}$ & $\begin{array}{l}0.161^{* * *} \\
(0.047)\end{array}$ & $\begin{array}{l}-0.102^{* * *} \\
(0.037)\end{array}$ & $\begin{array}{l}-0.265^{\text {*** }} \\
(0.019)\end{array}$ & $\begin{array}{l}-0.204^{* * *} \\
(0.029)\end{array}$ & $\begin{array}{c}0.049 \\
(0.088)\end{array}$ \\
\hline Age & $\begin{array}{l}0.081^{* * *} \\
(0.003)\end{array}$ & $\begin{array}{l}0.081^{* * *} \\
(0.005)\end{array}$ & $\begin{array}{l}0.076^{* * *} \\
(0.002)\end{array}$ & $\begin{array}{l}0.101^{* * *} \\
(0.006)\end{array}$ & $\begin{array}{l}0.089^{* * *} \\
(0.005)\end{array}$ & $\begin{array}{l}0.071^{* * *} \\
(0.002)\end{array}$ & $\begin{array}{l}0.058^{* * *} \\
(0.004)\end{array}$ & $\begin{array}{l}0.059^{* * *} \\
(0.014)\end{array}$ \\
\hline Age Sq & $\begin{array}{l}-0.001^{* * *} \\
(0.000)\end{array}$ & $\begin{array}{l}-0.001^{* * *} \\
(0.000)\end{array}$ & $\begin{array}{l}-0.001^{* * *} \\
(0.000)\end{array}$ & $\begin{array}{l}-0.001^{* * *} \\
(0.000)\end{array}$ & $\begin{array}{l}-0.001^{* * *} \\
(0.000)\end{array}$ & $\begin{array}{l}-0.001^{* * *} \\
(0.000)\end{array}$ & $\begin{array}{l}-0.001^{* * * *} \\
(0.000)\end{array}$ & $\begin{array}{l}-0.001^{* * *} \\
(0.000)\end{array}$ \\
\hline African American & $\begin{array}{l}-0.143^{\text {*** }} \\
(0.014)\end{array}$ & $\begin{array}{l}-0.289^{* * *} \\
(0.027)\end{array}$ & $\begin{array}{l}-0.176^{* * *} \\
(0.008)\end{array}$ & $\begin{array}{l}-0.113^{* * *} \\
(0.024)\end{array}$ & $\begin{array}{l}-0.175^{* * *} \\
(0.016)\end{array}$ & $\begin{array}{l}-0.238^{* * *} \\
(0.010)\end{array}$ & $\begin{array}{l}-0.380^{* * *} \\
(0.024)\end{array}$ & $\begin{array}{l}-0.306^{* * *} \\
(0.064)\end{array}$ \\
\hline Hispanic & $\begin{array}{l}-0.093^{* * *} \\
(0.010)\end{array}$ & $\begin{array}{l}-0.283^{* * *} \\
(0.021)\end{array}$ & $\begin{array}{l}-0.174^{* * *} \\
(0.008)\end{array}$ & $\begin{array}{l}-0.087^{* * *} \\
(0.022)\end{array}$ & $\begin{array}{l}-0.167^{* * *} \\
(0.016)\end{array}$ & $\begin{array}{l}-0.258^{* * *} \\
(0.008)\end{array}$ & $\begin{array}{l}-0.212^{\text {*** }} \\
(0.014)\end{array}$ & $\begin{array}{l}-0.100^{* *} \\
(0.047)\end{array}$ \\
\hline High School Graduate & $\begin{array}{l}0.253^{* * *} \\
(0.010)\end{array}$ & $\begin{array}{l}0.284^{* * *} \\
(0.018)\end{array}$ & $\begin{array}{l}0.364^{* * *} \\
(0.008)\end{array}$ & $\begin{array}{l}0.447^{* * *} \\
(0.041)\end{array}$ & $\begin{array}{l}0.319^{* * *} \\
(0.021)\end{array}$ & $\begin{array}{l}0.272^{\text {*** }} \\
(0.007)\end{array}$ & $\begin{array}{l}0.266^{* * *} \\
(0.013)\end{array}$ & $\begin{array}{l}0.279^{* * *} \\
(0.039)\end{array}$ \\
\hline College & $\begin{array}{l}0.396^{* * *} \\
(0.013)\end{array}$ & $\begin{array}{l}0.461^{* * *} \\
(0.017)\end{array}$ & $\begin{array}{l}0.554^{* * *} \\
(0.006)\end{array}$ & $\begin{array}{l}0.498^{* * *} \\
(0.017)\end{array}$ & $\begin{array}{l}0.434^{* * *} \\
(0.014)\end{array}$ & $\begin{array}{l}0.551^{* * *} \\
(0.008)\end{array}$ & $\begin{array}{l}0.338^{* * *} \\
(0.021)\end{array}$ & $\begin{array}{l}0.499^{* * *} \\
(0.038)\end{array}$ \\
\hline Female & $\begin{array}{l}-0.527^{* * *} \\
(0.008)\end{array}$ & $\begin{array}{l}-0.449^{* * *} \\
(0.014)\end{array}$ & $\begin{array}{l}-0.413^{\text {*** }} \\
(0.006)\end{array}$ & $\begin{array}{l}-0.337^{* * *} \\
(0.016)\end{array}$ & $\begin{array}{l}-0.306^{\text {*** }} \\
(0.012)\end{array}$ & $\begin{array}{l}-0.442^{\text {*** }} \\
(0.006)\end{array}$ & $\begin{array}{l}-0.385^{* * *} \\
(0.019)\end{array}$ & $\begin{array}{l}-0.446^{* * *} \\
(0.041)\end{array}$ \\
\hline Constant & $\begin{array}{l}8.155^{* * *} \\
(0.057)\end{array}$ & $\begin{array}{l}8.576^{\text {*** }} \\
(0.106)\end{array}$ & $\begin{array}{l}8.140^{* * * *} \\
(0.042)\end{array}$ & $\begin{array}{l}7.561^{* * * *} \\
(0.130)\end{array}$ & $\begin{array}{l}8.206^{* * *} \\
(0.107)\end{array}$ & $\begin{array}{l}8.757^{* * * *} \\
(0.046)\end{array}$ & $\begin{array}{l}8.929 \text { *** } \\
(0.083)\end{array}$ & $\begin{array}{l}9.077^{* * * *} \\
(0.286) \\
\end{array}$ \\
\hline Observations & 57739 & 14158 & 120231 & 13257 & 20872 & 73359 & 27138 & 3187 \\
\hline$R^{2}$ & 0.180 & 0.249 & 0.235 & 0.220 & 0.176 & 0.288 & 0.116 & 0.203 \\
\hline
\end{tabular}

Notes: This table presents estimates of Equation (3), including covariates but not fixed effects. The dependent variable is log wages. The specification estimated is: $\log w_{j, t}^{i}=\gamma_{g}^{i}+X_{j, t}^{\prime} \beta^{i}+\varepsilon_{j, t}^{i}$. The data from the CPS and BEA are merged at the state geographic level and one-digit industry code as described in Appendix A. The generation variables are all dummy variables defined on the basis of date of birth, as per Table 1. The omitted category is the Silent Generation. $X$ contains education, race, gender, and age variables. Standard errors are in parenthesis. ${ }^{* * *}$ Significant at the $1 \%$ level.** Significant at the $5 \%$ level. ${ }^{*}$ Significant at the $10 \%$ level. 
Table B.3: Generational differences in real wages by industry: Including covariates and occupation controls

\begin{tabular}{|c|c|c|c|c|c|c|c|c|}
\hline & $\begin{array}{c}(1) \\
\text { Retail } \\
\beta / \mathrm{SE}\end{array}$ & $\begin{array}{c}(2) \\
\text { Wholesale } \\
\beta / \mathrm{SE}\end{array}$ & $\begin{array}{c}(3) \\
\text { Services } \\
\beta / \mathrm{SE}\end{array}$ & $\begin{array}{c}(4) \\
\text { Finance } \\
\beta / \mathrm{SE}\end{array}$ & $\begin{array}{c}(5) \\
\text { Utilities } \\
\beta / \mathrm{SE}\end{array}$ & $\begin{array}{c}(6) \\
\text { Manufacturing } \\
\beta / \mathrm{SE}\end{array}$ & $\begin{array}{c}(7) \\
\text { Construction } \\
\beta / \mathrm{SE}\end{array}$ & $\begin{array}{c}(8) \\
\text { Mining } \\
\beta / \mathrm{SE}\end{array}$ \\
\hline Baby Boomers & $\begin{array}{l}0.026^{* *} \\
(0.012)\end{array}$ & $\begin{array}{l}-0.010 \\
(0.019)\end{array}$ & $\begin{array}{l}0.110^{* * *} \\
(0.009)\end{array}$ & $\begin{array}{l}0.082^{* *} \\
(0.032)\end{array}$ & $\begin{array}{c}0.021 \\
(0.023)\end{array}$ & $\begin{array}{l}-0.041^{* * *} \\
(0.008)\end{array}$ & $\begin{array}{l}-0.114^{* * *} \\
(0.017)\end{array}$ & $\begin{array}{l}-0.041 \\
(0.047)\end{array}$ \\
\hline Gen. X. & $\begin{array}{l}0.037^{* *} \\
(0.015)\end{array}$ & $\begin{array}{l}-0.008 \\
(0.024)\end{array}$ & $\begin{array}{l}0.159^{* * *} \\
(0.011)\end{array}$ & $\begin{array}{l}0.150^{* * * *} \\
(0.038)\end{array}$ & $\begin{array}{l}-0.007 \\
(0.027)\end{array}$ & $\begin{array}{l}-0.099^{* * *} \\
(0.011)\end{array}$ & $\begin{array}{l}-0.123^{* * *} \\
(0.021)\end{array}$ & $\begin{array}{l}-0.059 \\
(0.063)\end{array}$ \\
\hline Millennials & $\begin{array}{l}-0.001 \\
(0.019)\end{array}$ & $\begin{array}{l}-0.067^{*} \\
(0.039)\end{array}$ & $\begin{array}{l}0.150^{* * *} \\
(0.014)\end{array}$ & $\begin{array}{l}0.124^{* * *} \\
(0.045)\end{array}$ & $\begin{array}{l}-0.062^{*} \\
(0.035)\end{array}$ & $\begin{array}{l}-0.153^{* * *} \\
(0.018)\end{array}$ & $\begin{array}{l}-0.159^{* * *} \\
(0.028)\end{array}$ & $\begin{array}{c}0.128 \\
(0.085)\end{array}$ \\
\hline Age & $\begin{array}{l}0.075^{* * *} \\
(0.003)\end{array}$ & $\begin{array}{l}0.076^{* * *} \\
(0.005)\end{array}$ & $\begin{array}{l}0.073^{* * *} \\
(0.002)\end{array}$ & $\begin{array}{l}0.090^{* * *} \\
(0.006)\end{array}$ & $\begin{array}{l}0.085^{* * *} \\
(0.005)\end{array}$ & $\begin{array}{l}0.069^{* * *} \\
(0.002)\end{array}$ & $\begin{array}{l}0.055^{* * *} \\
(0.004)\end{array}$ & $\begin{array}{l}0.053^{* * *} \\
(0.013)\end{array}$ \\
\hline Age Sq & $\begin{array}{l}-0.001^{* * *} \\
(0.000)\end{array}$ & $\begin{array}{l}* 0.001^{* * *} * \\
(0.000)\end{array}$ & $\begin{array}{l}-0.001^{* * *} \\
(0.000)\end{array}$ & $\begin{array}{l}-0.001^{* * *} \\
(0.000)\end{array}$ & $\begin{array}{l}-0.001^{* * *} \\
(0.000)\end{array}$ & $\begin{array}{l}-0.001^{* * *} \\
(0.000)\end{array}$ & $\begin{array}{l}-0.001^{* * *} \\
(0.000)\end{array}$ & $\begin{array}{l}-0.001^{* * *} \\
(0.000)\end{array}$ \\
\hline African American & $\begin{array}{l}-0.106^{* * *} \\
(0.013)\end{array}$ & $\begin{array}{ll}* & -0.195^{* * *} \\
& (0.025)\end{array}$ & $\begin{array}{l}-0.075^{* * *} \\
(0.008)\end{array}$ & $\begin{array}{l}-0.073^{* * *} \\
(0.023)\end{array}$ & $\begin{array}{l}-0.108^{* * *} \\
(0.016)\end{array}$ & $\begin{array}{l}-0.149^{* * *} \\
(0.010)\end{array}$ & $\begin{array}{l}-0.311^{* * *} \\
(0.024)\end{array}$ & $\begin{array}{l}-0.246^{* * *} \\
(0.064)\end{array}$ \\
\hline Hispanic & $\begin{array}{l}-0.033^{* * *} \\
(0.010)\end{array}$ & $\begin{array}{l}* 0.207^{* * *} \\
(0.020)\end{array}$ & $\begin{array}{l}-0.082^{* * *} \\
(0.008)\end{array}$ & $\begin{array}{l}-0.042^{* *} \\
(0.020)\end{array}$ & $\begin{array}{l}-0.134^{* * *} \\
(0.016)\end{array}$ & $\begin{array}{l}-0.205^{* * *} \\
(0.008)\end{array}$ & $\begin{array}{l}-0.172^{* * *} \\
(0.014)\end{array}$ & $\begin{array}{l}-0.073 \\
(0.046)\end{array}$ \\
\hline High School Graduate & $\begin{array}{l}0.171^{* * *} \\
(0.010)\end{array}$ & $\begin{array}{l}0.178^{* * * *} \\
(0.018)\end{array}$ & $\begin{array}{l}0.184^{* * *} \\
(0.008)\end{array}$ & $\begin{array}{l}0.232^{\text {*** }} \\
(0.042)\end{array}$ & $\begin{array}{l}0.204^{* * * *} \\
(0.022)\end{array}$ & $\begin{array}{l}0.159^{* * *} \\
(0.007)\end{array}$ & $\begin{array}{l}0.205^{* * *} \\
(0.013)\end{array}$ & $\begin{array}{l}0.237^{* * *} \\
(0.039)\end{array}$ \\
\hline College & $\begin{array}{l}0.289^{* * *} \\
(0.012)\end{array}$ & $\begin{array}{l}0.335^{* * *} \\
(0.018)\end{array}$ & $\begin{array}{l}0.324^{* * *} \\
(0.007)\end{array}$ & $\begin{array}{l}0.334^{* * *} \\
(0.017)\end{array}$ & $\begin{array}{l}0.281^{* * *} \\
(0.014)\end{array}$ & $\begin{array}{l}0.308^{* * *} \\
(0.008)\end{array}$ & $\begin{array}{l}0.118^{* * *} \\
(0.020)\end{array}$ & $\begin{array}{l}0.269^{* * *} \\
(0.046)\end{array}$ \\
\hline Female & $\begin{array}{l}-0.513^{* * *} \\
(0.008)\end{array}$ & $\begin{array}{l}* 0.520^{* * *} \\
(0.015)\end{array}$ & $\begin{array}{l}-0.429^{* * *} \\
(0.006)\end{array}$ & $\begin{array}{l}-0.383^{* * *} \\
(0.017)\end{array}$ & $\begin{array}{l}-0.348^{* * *} \\
(0.014)\end{array}$ & $\begin{array}{l}-0.432^{* * *} \\
(0.006)\end{array}$ & $\begin{array}{l}-0.514^{* * *} \\
(0.023)\end{array}$ & $\begin{array}{l}-0.473^{* * *} \\
(0.044)\end{array}$ \\
\hline Technical Sales \& Administrative Support & $\begin{array}{l}-0.432^{* * *} \\
(0.012)\end{array}$ & $\begin{array}{l}* 0.247^{* * *} \\
(0.017)\end{array}$ & $\begin{array}{l}-0.266^{* * *} \\
(0.007)\end{array}$ & $\begin{array}{l}-0.383^{\text {**** }} \\
(0.016)\end{array}$ & $\begin{array}{l}-0.332^{* * *} \\
(0.016)\end{array}$ & $\begin{array}{l}-0.300^{* * *} \\
(0.009)\end{array}$ & $\begin{array}{l}-0.419^{* * *} \\
(0.025)\end{array}$ & $\begin{array}{l}-0.376^{* * *} \\
(0.043)\end{array}$ \\
\hline Service & $\begin{array}{l}-0.804^{* * *} \\
(0.013)\end{array}$ & $\begin{array}{l}-0.878^{* * *} \\
(0.080)\end{array}$ & $\begin{array}{l}-0.673^{* * *} \\
(0.008)\end{array}$ & $\begin{array}{l}-0.807^{* * *} \\
(0.033)\end{array}$ & $\begin{array}{l}-0.547^{* * *} \\
(0.034)\end{array}$ & $\begin{array}{l}-0.717^{* * *} \\
(0.029)\end{array}$ & $\begin{array}{l}-1.040^{* * *} \\
(0.084)\end{array}$ & $\begin{array}{l}-1.003^{* * *} \\
(0.156)\end{array}$ \\
\hline Farming, Forestry \& Fishing & $\begin{array}{l}-0.855^{* * *} \\
(0.099)\end{array}$ & $\begin{array}{l}-0.832^{* * *} \\
(0.059)\end{array}$ & $\begin{array}{l}-0.825^{* * *} \\
(0.036)\end{array}$ & $\begin{array}{l}-0.868^{* * *} \\
(0.082)\end{array}$ & $\begin{array}{l}-0.815^{* * * *} \\
(0.159)\end{array}$ & $\begin{array}{l}-0.886^{* * *} \\
(0.047)\end{array}$ & $\begin{array}{l}-0.976^{\text {*** }} \\
(0.156)\end{array}$ & $\begin{array}{l}-0.847^{* * *} \\
(0.203)\end{array}$ \\
\hline Precision Production, Craft \& Repair & $\begin{array}{l}-0.302^{* * *} \\
(0.016)\end{array}$ & $\begin{array}{l}-0.364^{* * *} \\
(0.026)\end{array}$ & $\begin{array}{l}-0.342^{* * *} \\
(0.013)\end{array}$ & $\begin{array}{l}-0.572^{* * * *} \\
(0.039)\end{array}$ & $\begin{array}{l}-0.174^{* * *} \\
(0.018)\end{array}$ & $\begin{array}{l}-0.323^{* * *} \\
(0.009)\end{array}$ & $\begin{array}{l}-0.551^{* * *} \\
(0.016)\end{array}$ & $\begin{array}{l}-0.339^{* * *} \\
(0.046)\end{array}$ \\
\hline Operators, Fabricators \& Labourers & $\begin{array}{l}-0.620^{* * *} \\
(0.017)\end{array}$ & $\begin{array}{l}* 0.565^{* * *} \\
(0.022)\end{array}$ & $\begin{array}{l}-0.726^{* * *} \\
(0.015)\end{array}$ & $\begin{array}{l}-0.817^{* * *} \\
(0.135)\end{array}$ & $\begin{array}{l}-0.575^{* * *} \\
(0.018)\end{array}$ & $\begin{array}{l}-0.574^{* * *} \\
(0.008)\end{array}$ & $\begin{array}{l}-0.696^{* * *} \\
(0.019)\end{array}$ & $\begin{array}{l}-0.525^{\text {*** }} \\
(0.053)\end{array}$ \\
\hline Constant & $\begin{array}{l}8.741^{* * *} \\
(0.055)\end{array}$ & $\begin{array}{l}8.973^{* * *} \\
(0.103)\end{array}$ & $\begin{array}{l}8.599^{* * *} \\
(0.041)\end{array}$ & $\begin{array}{l}8.349^{* * *} \\
(0.128)\end{array}$ & $\begin{array}{l}8.714^{\text {*** }} \\
(0.104)\end{array}$ & $\begin{array}{l}9.201^{* * *} \\
(0.045)\end{array}$ & $\begin{array}{l}9.527^{* * *} \\
(0.081)\end{array}$ & $\begin{array}{l}9.518^{* * *} \\
(0.278)\end{array}$ \\
\hline Observations & 57739 & 14158 & 120231 & 13257 & 20872 & 73359 & 27138 & 3187 \\
\hline$R^{2}$ & 0.252 & 0.298 & 0.301 & 0.296 & 0.245 & 0.350 & 0.172 & 0.259 \\
\hline
\end{tabular}

Notes: This table presents estimates of Equation (3), including covariates but not fixed effects. The dependent variable is log wages. The specification estimated is: $\log w_{j, t}^{i}=\gamma_{g}^{i}+X_{j, t}^{\prime} \beta^{i}+\varepsilon_{j, t}^{i}$. The data from the CPS and BEA are merged at the state geographic level and one-digit industry code as described in Appendix A. The generation variables are all dummy variables defined on the basis of date of birth, as per Table 1 . The omitted category is the Silent Generation. $X$ contains education, race, gender, and age variables. The reference occupation group is Managerial \& Professional Speciality. Standard errors are in parenthesis. ${ }^{* *}$ Significant at the $1 \%$ level. ${ }^{* *}$ Significant at the $5 \%$ level. ${ }^{*}$ Significant at the $10 \%$ level. 
Table B.4: Generational differences in real wages by industry: Including covariates and state fixed effects

\begin{tabular}{|c|c|c|c|c|c|c|c|c|}
\hline & $\begin{array}{c}(1) \\
\text { Retail } \\
\beta / \mathrm{SE}\end{array}$ & $\begin{array}{c}(2) \\
\text { Wholesale } \\
\beta / \mathrm{SE}\end{array}$ & $\begin{array}{c}(3) \\
\text { Services } \\
\beta / \mathrm{SE}\end{array}$ & $\begin{array}{c}(4) \\
\text { Finance } \\
\beta / \mathrm{SE}\end{array}$ & $\begin{array}{c}(5) \\
\text { Utilities } \\
\beta / \mathrm{SE}\end{array}$ & $\begin{array}{c}(6) \\
\text { Manufacturing } \\
\beta / \mathrm{SE}\end{array}$ & $\begin{array}{c}(7) \\
\text { Construction } \\
\beta / \mathrm{SE}\end{array}$ & $\begin{array}{c}(8) \\
\text { Mining } \\
\beta / \mathrm{SE}\end{array}$ \\
\hline Baby Boomers & $\begin{array}{l}0.026^{* *} \\
(0.011)\end{array}$ & $\begin{array}{l}-0.007 \\
(0.019)\end{array}$ & $\begin{array}{l}0.116^{* * *} \\
(0.013)\end{array}$ & $\begin{array}{l}0.094^{* * *} \\
(0.034)\end{array}$ & $\begin{array}{c}0.022 \\
(0.025)\end{array}$ & $\begin{array}{l}-0.035^{* * *} \\
(0.011)\end{array}$ & $\begin{array}{l}-0.046 \\
(0.031)\end{array}$ & $\begin{array}{l}-0.148^{*} \\
(0.063)\end{array}$ \\
\hline Gen. X. & $\begin{array}{l}0.038^{* *} \\
(0.017)\end{array}$ & $\begin{array}{l}-0.002 \\
(0.026)\end{array}$ & $\begin{array}{l}0.169^{* * *} \\
(0.015)\end{array}$ & $\begin{array}{l}0.166^{* * *} \\
(0.042)\end{array}$ & $\begin{array}{l}-0.005 \\
(0.031)\end{array}$ & $\begin{array}{l}-0.087^{* * *} \\
(0.015)\end{array}$ & $\begin{array}{l}-0.028 \\
(0.050)\end{array}$ & $\begin{array}{l}-0.274^{*} \\
(0.126)\end{array}$ \\
\hline Millennials & $\begin{array}{c}0.002 \\
(0.019)\end{array}$ & $\begin{array}{l}-0.055 \\
(0.051)\end{array}$ & $\begin{array}{l}0.164^{* * *} \\
(0.022)\end{array}$ & $\begin{array}{l}0.138^{* * *} \\
(0.045)\end{array}$ & $\begin{array}{l}-0.060^{*} \\
(0.032)\end{array}$ & $\begin{array}{l}-0.140^{\text {*** }} \\
(0.023)\end{array}$ & $\begin{array}{l}-0.042 \\
(0.065)\end{array}$ & $\begin{array}{l}-0.233 \\
(0.153)\end{array}$ \\
\hline Age & $\begin{array}{l}0.074^{* * *} \\
(0.002)\end{array}$ & $\begin{array}{l}0.077^{* * *} \\
(0.005)\end{array}$ & $\begin{array}{l}0.073^{* * *} \\
(0.002)\end{array}$ & $\begin{array}{l}0.089^{* * *} \\
(0.005)\end{array}$ & $\begin{array}{l}0.085^{* * *} \\
(0.003)\end{array}$ & $\begin{array}{l}0.068^{* * *} \\
(0.002)\end{array}$ & $\begin{array}{l}0.057^{* * *} \\
(0.005)\end{array}$ & $\begin{array}{l}0.048^{* *} \\
(0.018)\end{array}$ \\
\hline Age Sq & $\begin{array}{l}-0.001^{* * *} \\
(0.000)\end{array}$ & $\begin{array}{l}-0.001^{* * *} \\
(0.000)\end{array}$ & $\begin{array}{l}-0.001^{* * *} \\
(0.000)\end{array}$ & $\begin{array}{l}-0.001^{* * * *} \\
(0.000)\end{array}$ & $\begin{array}{l}-0.001^{* * *} \\
(0.000)\end{array}$ & $\begin{array}{l}-0.001^{* * *} \\
(0.000)\end{array}$ & $\begin{array}{l}-0.001^{* * *} \\
(0.000)\end{array}$ & $\begin{array}{l}-0.001^{* *} \\
(0.000)\end{array}$ \\
\hline African American & $\begin{array}{l}-0.115^{* * *} \\
(0.011)\end{array}$ & $\begin{array}{l}-0.208^{* * *} \\
(0.020)\end{array}$ & $\begin{array}{l}-0.085^{* * *} \\
(0.011)\end{array}$ & $\begin{array}{l}-0.104^{* * *} \\
(0.023)\end{array}$ & $\begin{array}{l}-0.121^{* * *} \\
(0.015)\end{array}$ & $\begin{array}{l}-0.129^{* * *} \\
(0.016)\end{array}$ & $\begin{array}{l}-0.286^{* * *} \\
(0.034)\end{array}$ & $\begin{array}{l}-0.257^{*} \\
(0.107)\end{array}$ \\
\hline Hispanic & $\begin{array}{l}-0.065^{* * * *} \\
(0.014)\end{array}$ & $\begin{array}{l}-0.234^{* * *} \\
(0.026)\end{array}$ & $\begin{array}{l}-0.115^{* * *} \\
(0.017)\end{array}$ & $\begin{array}{l}-0.071^{* *} \\
(0.029)\end{array}$ & $\begin{array}{l}-0.155^{\text {*** }} \\
(0.016)\end{array}$ & $\begin{array}{l}-0.232^{\text {*** }} \\
(0.012)\end{array}$ & $\begin{array}{l}-0.193^{* * *} \\
(0.034)\end{array}$ & $\begin{array}{l}-0.104^{*} \\
(0.049)\end{array}$ \\
\hline High School Graduate & $\begin{array}{l}0.168^{* * *} \\
(0.011)\end{array}$ & $\begin{array}{l}0.180^{* * *} \\
(0.019)\end{array}$ & $\begin{array}{l}0.182^{* * *} \\
(0.010)\end{array}$ & $\begin{array}{l}0.234^{* * *} \\
(0.041)\end{array}$ & $\begin{array}{l}0.208^{* * *} \\
(0.020)\end{array}$ & $\begin{array}{l}0.155^{* * *} \\
(0.010)\end{array}$ & $\begin{array}{l}0.232^{* * *} \\
(0.025)\end{array}$ & $\begin{array}{l}0.257^{\text {*** }} \\
(0.058)\end{array}$ \\
\hline College & $\begin{array}{l}0.282^{* * *} \\
(0.015)\end{array}$ & $\begin{array}{l}0.327^{* * *} \\
(0.017)\end{array}$ & $\begin{array}{l}0.311^{* * *} \\
(0.008)\end{array}$ & $\begin{array}{l}0.315^{* * *} \\
(0.022)\end{array}$ & $\begin{array}{l}0.273^{* * *} \\
(0.019)\end{array}$ & $\begin{array}{l}0.301^{* * *} \\
(0.007)\end{array}$ & $\begin{array}{l}0.112^{* * *} \\
(0.027)\end{array}$ & $\begin{array}{l}0.286^{* * *} \\
(0.050)\end{array}$ \\
\hline Female & $\begin{array}{l}-0.510^{* * *} \\
(0.013)\end{array}$ & $\begin{array}{l}-0.522^{* * *} \\
(0.015)\end{array}$ & $\begin{array}{l}-0.422^{* * *} \\
(0.012)\end{array}$ & $\begin{array}{l}-0.371^{* * *} \\
(0.014)\end{array}$ & $\begin{array}{l}-0.348^{* * *} \\
(0.017)\end{array}$ & $\begin{array}{l}-0.427^{* * *} \\
(0.009)\end{array}$ & $\begin{array}{l}-0.511^{* * *} \\
(0.052)\end{array}$ & $\begin{array}{l}-0.458^{* * *} \\
(0.067)\end{array}$ \\
\hline Technical Sales \& Administrative Support & $\begin{array}{l}-0.430^{* * *} \\
(0.015)\end{array}$ & $\begin{array}{l}-0.243^{* * *} \\
(0.017)\end{array}$ & $\begin{array}{l}-0.265^{* * *} \\
(0.007)\end{array}$ & $\begin{array}{l}-0.380^{* * *} \\
(0.017)\end{array}$ & $\begin{array}{l}-0.331^{* * *} \\
(0.018)\end{array}$ & $\begin{array}{l}-0.299^{* * *} \\
(0.008)\end{array}$ & $\begin{array}{l}-0.422^{\text {*** }} \\
(0.038)\end{array}$ & $\begin{array}{l}-0.359^{* * *} \\
(0.050)\end{array}$ \\
\hline Service & $\begin{array}{l}-0.801^{* * *} \\
(0.015)\end{array}$ & $\begin{array}{l}-0.860^{* * * *} \\
(0.089)\end{array}$ & $\begin{array}{l}-0.670^{* * *} \\
(0.010)\end{array}$ & $\begin{array}{l}-0.802^{* * *} \\
(0.028)\end{array}$ & $\begin{array}{l}-0.547^{* * *} \\
(0.041)\end{array}$ & $\begin{array}{l}-0.709^{* * *} \\
(0.029)\end{array}$ & $\begin{array}{l}-1.030^{* * *} \\
(0.082)\end{array}$ & $\begin{array}{l}-0.958^{* *} \\
(0.239)\end{array}$ \\
\hline Farming, Forestry \& Fishing & $\begin{array}{l}-0.849^{* * *} \\
(0.102)\end{array}$ & $\begin{array}{l}-0.813^{* * *} \\
(0.061)\end{array}$ & $\begin{array}{l}-0.813^{* * *} \\
(0.039)\end{array}$ & $\begin{array}{l}-0.859^{* * *} \\
(0.080)\end{array}$ & $\begin{array}{l}-0.792^{* * *} \\
(0.144)\end{array}$ & $\begin{array}{l}-0.843^{\text {*** }} \\
(0.049)\end{array}$ & $\begin{array}{l}-0.953^{* * *} \\
(0.222)\end{array}$ & $\begin{array}{l}-0.820^{* *} \\
(0.211)\end{array}$ \\
\hline Precision Production, Craft \& Repair & $\begin{array}{l}-0.297^{* * *} \\
(0.020)\end{array}$ & $\begin{array}{l}-0.352^{* * *} \\
(0.022)\end{array}$ & $\begin{array}{l}-0.336^{* * *} \\
(0.017)\end{array}$ & $\begin{array}{l}-0.565^{* * *} \\
(0.042)\end{array}$ & $\begin{array}{l}-0.168^{* * *} \\
(0.018)\end{array}$ & $\begin{array}{l}-0.315^{\text {*** }} \\
(0.014)\end{array}$ & $\begin{array}{l}-0.538^{* * *} \\
(0.026)\end{array}$ & $\begin{array}{l}-0.310^{* * *} \\
(0.038)\end{array}$ \\
\hline Operators, Fabricators \& Labourers & $\begin{array}{l}-0.614^{* * *} \\
(0.022)\end{array}$ & $\begin{array}{l}-0.553^{* * *} \\
(0.021)\end{array}$ & $\begin{array}{l}-0.718^{* * *} \\
(0.016)\end{array}$ & $\begin{array}{l}-0.821^{\text {*** }} \\
(0.123)\end{array}$ & $\begin{array}{l}-0.569^{\text {*** }} \\
(0.020)\end{array}$ & $\begin{array}{l}-0.564^{* * *} \\
(0.018)\end{array}$ & $\begin{array}{l}-0.686^{* * *} \\
(0.023)\end{array}$ & $\begin{array}{l}-0.480^{* * *} \\
(0.024)\end{array}$ \\
\hline Constant & $\begin{array}{l}8.749^{* * *} \\
(0.044)\end{array}$ & $\begin{array}{l}8.945^{\text {*** }} \\
(0.113)\end{array}$ & $\begin{array}{l}8.591^{* * *} \\
(0.045)\end{array}$ & $\begin{array}{l}8.356^{\text {*** }} \\
(0.105)\end{array}$ & $\begin{array}{l}8.710^{* * *} \\
(0.074)\end{array}$ & $\begin{array}{l}9.198^{* * *} \\
(0.034)\end{array}$ & $\begin{array}{l}9.365^{* * *} \\
(0.145)\end{array}$ & $\begin{array}{l}9.851^{\text {*** }} \\
(0.472)\end{array}$ \\
\hline Observations & 57739 & 14158 & 120231 & 13257 & 20872 & 73359 & 27138 & 3186 \\
\hline$R^{2}$ & 0.257 & 0.305 & 0.306 & 0.307 & 0.251 & 0.358 & 0.197 & 0.294 \\
\hline
\end{tabular}

Notes: This table presents estimates of Equation (3), including covariates but not fixed effects. The dependent variable is log wages. The specification estimated is: $\log w_{j, t}^{i}=\gamma_{g}^{i}+X_{j, t}^{\prime} \beta^{i}+\delta_{s}^{i}+\varepsilon_{j, t}^{i}$. The data from the CPS and BEA are merged at the state geographic level and one-digit industry code as described in Appendix A. The generation variables are all dummy variables defined on the basis of date of birth, as per Table 1. The omitted category is the Silent Generation and omitted occupation group is Managerial \& Professional Speciality. $X$ contains education, race, gender, and age variables. Standard errors are in parenthesis. ${ }^{* * *}$ Significant at the $1 \%$ level.** Significant at the $5 \%$ level. ${ }^{*}$ Significant at the $10 \%$ level.

Table B.5: Generational differences in labour share by industry: Unconditional results

\begin{tabular}{llllllllc}
\hline & $\begin{array}{c}(1) \\
\text { Retail }\end{array}$ & $\begin{array}{c}\text { Wholesale } \\
\beta / \mathrm{SE}\end{array}$ & $\begin{array}{c}\text { Services } \\
\beta / \mathrm{SE}\end{array}$ & $\begin{array}{c}\text { Finance } \\
\beta / \mathrm{SE}\end{array}$ & $\begin{array}{c}(5) \\
\text { Utilities } \\
\beta / \mathrm{SE}\end{array}$ & $\begin{array}{c}(6) \\
\text { Manufacturing } \\
\beta / \mathrm{SE}\end{array}$ & $\begin{array}{c}(7) \\
\text { Construction } \\
\beta / \mathrm{SE}\end{array}$ & $\begin{array}{c}(8) \\
\text { Mining } \\
\beta / \mathrm{SE}\end{array}$ \\
\hline Baby Boomers & $-0.004^{* * *}$ & $0.000^{* * *}$ & $0.002^{* * *}$ & $0.074^{* * *}$ & $0.059^{* * *}$ & $-0.033^{* * *}$ & $-0.008^{* * *}$ & $-0.012^{* * *}$ \\
& $(0.000)$ & $(0.000)$ & $(0.000)$ & $(0.008)$ & $(0.008)$ & $(0.001)$ & $(0.000)$ & $(0.004)$ \\
Gen. X. & $-0.007^{* * *}$ & 0.000 & $0.003^{* * *}$ & $0.119^{* * *}$ & $0.110^{* * *}$ & $-0.068^{* * *}$ & $-0.017^{* * *}$ & $-0.035^{* * *}$ \\
& $(0.000)$ & $(0.000)$ & $(0.000)$ & $(0.008)$ & $(0.009)$ & $(0.000)$ & $(0.000)$ & $(0.004)$ \\
Millennials & $-0.010^{* * *}$ & $-0.002^{* * *}$ & $0.004^{* * *}$ & $0.149^{* * *}$ & $0.099^{* * *}$ & $-0.076^{* * *}$ & $-0.022^{* * *}$ & $-0.044^{* * *}$ \\
& $(0.000)$ & $(0.000)$ & $(0.000)$ & $(0.009)$ & $(0.008)$ & $(0.000)$ & $(0.000)$ & $(0.004)$ \\
Constant & $0.037^{* * *}$ & $0.017^{* * *}$ & $0.126^{* * *}$ & $0.248^{* * *}$ & $0.137^{* * *}$ & $0.113^{* * *}$ & $0.081^{* * *}$ & $0.086^{* * *}$ \\
& $(0.000)$ & $(0.000)$ & $(0.000)$ & $(0.007)$ & $(0.008)$ & $(0.000)$ & $(0.000)$ & $(0.004)$ \\
\hline Observations & 57739 & 14158 & 120231 & 13102 & 20827 & 73359 & 27138 & 3172 \\
$R^{2}$ & 0.229 & 0.014 & 0.004 & 0.038 & 0.014 & 0.236 & 0.176 & 0.062 \\
\hline
\end{tabular}

Notes: This table presents estimates of Equation (3), excluding covariates and fixed effects. The dependent variable is the labour share of value added. The specification estimated is: $\log w_{j, t}^{i}=\gamma_{g}^{i}+\varepsilon_{j, t}^{i}$. The data from the CPS and BEA are merged at the state geographic level and one-digit industry code as described in Appendix A. The generation variables are all dummy variables defined on the basis of date of birth, as per Table 1. The omitted category is the Silent Generation. Standard errors are in parenthesis. ${ }^{* * *}$ Significant at the $1 \%$ level. ${ }^{* *}$ Significant at the $5 \%$ level. ${ }^{*}$ Significant at the $10 \%$ level. 
Table B.6: Generational differences in labour share by industry: Including covariates

\begin{tabular}{|c|c|c|c|c|c|c|c|c|}
\hline & $\begin{array}{c}(1) \\
\text { Retail } \\
\beta / \mathrm{SE}\end{array}$ & $\begin{array}{c}(2) \\
\text { Wholesale } \\
\beta / \mathrm{SE}\end{array}$ & $\begin{array}{c}(3) \\
\text { Services } \\
\beta / \mathrm{SE}\end{array}$ & $\begin{array}{c}(4) \\
\text { Finance } \\
\beta / \mathrm{SE}\end{array}$ & $\begin{array}{c}(5) \\
\text { Utilities } \\
\beta / \mathrm{SE}\end{array}$ & $\begin{array}{c}(6) \\
\text { Manufacturing } \\
\beta / \mathrm{SE}\end{array}$ & $\begin{array}{c}(7) \\
\text { Construction } \\
\beta / \mathrm{SE} \\
\end{array}$ & $\begin{array}{c}(8) \\
\text { Mining } \\
\beta / \mathrm{SE}\end{array}$ \\
\hline Baby Boomers & $\begin{array}{l}-0.007^{* * *} \\
(0.000)\end{array}$ & $\begin{array}{l}-0.000 \\
(0.000)\end{array}$ & $\begin{array}{l}0.004^{* * *} \\
(0.000)\end{array}$ & $\begin{array}{l}0.157^{* * *} \\
(0.008)\end{array}$ & $\begin{array}{l}0.130^{* * *} \\
(0.008)\end{array}$ & $\begin{array}{l}-0.058^{* * *} \\
(0.000)\end{array}$ & $\begin{array}{l}-0.013^{* * *} \\
(0.000)\end{array}$ & $\begin{array}{l}-0.021^{* * *} \\
(0.004)\end{array}$ \\
\hline Gen. X. & $\begin{array}{l}-0.014^{* * *} \\
(0.000)\end{array}$ & $\begin{array}{l}-0.001^{* * *} \\
(0.000)\end{array}$ & $\begin{array}{l}0.006^{* * *} \\
(0.000)\end{array}$ & $\begin{array}{l}0.305^{* * *} \\
(0.009)\end{array}$ & $\begin{array}{l}0.256^{* * *} \\
(0.008)\end{array}$ & $\begin{array}{l}-0.109^{* * *} \\
(0.001)\end{array}$ & $\begin{array}{l}-0.025^{* * *} \\
(0.000)\end{array}$ & $\begin{array}{l}-0.050^{* * *} \\
(0.005)\end{array}$ \\
\hline Millennials & $\begin{array}{l}-0.019^{* * *} \\
(0.000)\end{array}$ & $\begin{array}{l}-0.002^{\text {*** }} \\
(0.000)\end{array}$ & $\begin{array}{l}0.007^{* * *} \\
(0.000)\end{array}$ & $\begin{array}{l}0.394^{* * *} \\
(0.011)\end{array}$ & $\begin{array}{l}0.286^{* * *} \\
(0.010)\end{array}$ & $\begin{array}{l}-0.134^{* * *} \\
(0.001)\end{array}$ & $\begin{array}{l}-0.034^{* * *} \\
(0.000)\end{array}$ & $\begin{array}{l}-0.064^{* * *} \\
(0.006)\end{array}$ \\
\hline Age & $\begin{array}{l}-0.001^{\text {*** }} \\
(0.000)\end{array}$ & $\begin{array}{l}-0.000^{* *} \\
(0.000)\end{array}$ & $\begin{array}{l}0.000^{* * *} \\
(0.000)\end{array}$ & $\begin{array}{l}0.015^{* * *} \\
(0.001)\end{array}$ & $\begin{array}{l}0.006^{* * *} \\
(0.002)\end{array}$ & $\begin{array}{l}-0.003^{* * *} \\
(0.000)\end{array}$ & $\begin{array}{l}-0.001^{* * *} \\
(0.000)\end{array}$ & $\begin{array}{l}-0.000 \\
(0.001)\end{array}$ \\
\hline Age Sq & $\begin{array}{l}0.000^{* * *} \\
(0.000)\end{array}$ & $\begin{array}{c}0.000 \\
(0.000)\end{array}$ & $\begin{array}{c}0.000 \\
(0.000)\end{array}$ & $\begin{array}{l}-0.000^{* * *} \\
(0.000)\end{array}$ & $\begin{array}{c}0.000 \\
(0.000)\end{array}$ & $\begin{array}{l}0.000^{* * *} \\
(0.000)\end{array}$ & $\begin{array}{c}0.000 \\
(0.000)\end{array}$ & $\begin{array}{l}-0.000 \\
(0.000)\end{array}$ \\
\hline African American & $\begin{array}{l}-0.000^{* * *} \\
(0.000)\end{array}$ & $\begin{array}{l}-0.000 \\
(0.000)\end{array}$ & $\begin{array}{l}-0.000^{* *} \\
(0.000)\end{array}$ & $\begin{array}{l}0.015^{* *} \\
(0.006)\end{array}$ & $\begin{array}{l}-0.006 \\
(0.004)\end{array}$ & $\begin{array}{l}-0.007^{* * *} \\
(0.000)\end{array}$ & $\begin{array}{l}-0.001^{* * * *} \\
(0.000)\end{array}$ & $\begin{array}{l}-0.001 \\
(0.007)\end{array}$ \\
\hline Hispanic & $\begin{array}{l}-0.000^{* * *} \\
(0.000)\end{array}$ & $\begin{array}{l}-0.000^{* * *} \\
(0.000)\end{array}$ & $\begin{array}{l}-0.001^{\text {*** }} \\
(0.000)\end{array}$ & $\begin{array}{l}-0.026^{* * *} \\
(0.005)\end{array}$ & $\begin{array}{c}0.007 \\
(0.006)\end{array}$ & $\begin{array}{l}-0.012^{\text {*** }} \\
(0.000)\end{array}$ & $\begin{array}{l}-0.005^{* * *} \\
(0.000)\end{array}$ & $\begin{array}{l}-0.026^{* * *} \\
(0.003)\end{array}$ \\
\hline High School Graduate & $\begin{array}{l}-0.000^{* * *} \\
(0.000)\end{array}$ & $\begin{array}{l}0.001^{* * *} \\
(0.000)\end{array}$ & $\begin{array}{l}0.000^{* *} \\
(0.000)\end{array}$ & $\begin{array}{c}0.003 \\
(0.009)\end{array}$ & $\begin{array}{l}-0.005 \\
(0.008)\end{array}$ & $\begin{array}{l}-0.026^{* * *} \\
(0.000)\end{array}$ & $\begin{array}{l}-0.004^{* * *} \\
(0.000)\end{array}$ & $\begin{array}{l}-0.027^{* * *} \\
(0.004)\end{array}$ \\
\hline College & $\begin{array}{l}0.000^{* *} \\
(0.000)\end{array}$ & $\begin{array}{c}0.000 \\
(0.000)\end{array}$ & $\begin{array}{l}0.000^{* * *} \\
(0.000)\end{array}$ & $\begin{array}{l}0.013^{* * *} \\
(0.004)\end{array}$ & $\begin{array}{l}0.021^{* * *} \\
(0.006)\end{array}$ & $\begin{array}{l}-0.001^{* * *} \\
(0.000)\end{array}$ & $\begin{array}{l}-0.001^{*} \\
(0.000)\end{array}$ & $\begin{array}{l}-0.008^{* * *} \\
(0.002)\end{array}$ \\
\hline Female & $\begin{array}{l}-0.000^{* *} \\
(0.000)\end{array}$ & $\begin{array}{c}0.000^{*} \\
(0.000)\end{array}$ & $\begin{array}{c}0.000^{*} \\
(0.000)\end{array}$ & $\begin{array}{l}-0.008^{* *} \\
(0.004)\end{array}$ & $\begin{array}{c}0.001 \\
(0.005)\end{array}$ & $\begin{array}{l}-0.002^{* * *} \\
(0.000)\end{array}$ & $\begin{array}{l}-0.000 \\
(0.000)\end{array}$ & $\begin{array}{l}-0.004 \\
(0.003)\end{array}$ \\
\hline Constant & $\begin{array}{l}0.060^{* * *} \\
(0.000)\end{array}$ & $\begin{array}{l}0.019^{* * *} \\
(0.000)\end{array}$ & $\begin{array}{l}0.118^{\text {*** }} \\
(0.001)\end{array}$ & $\begin{array}{l}-0.337^{* * *} \\
(0.032)\end{array}$ & $\begin{array}{l}-0.208^{* * *} \\
(0.039)\end{array}$ & $\begin{array}{l}0.282^{* * * *} \\
(0.002)\end{array}$ & $\begin{array}{l}0.118^{\text {*** }} \\
(0.001)\end{array}$ & $\begin{array}{l}0.153^{* * *} \\
(0.022)\end{array}$ \\
\hline Observations & 57739 & 14158 & 120231 & 13102 & 20827 & 73359 & 27138 & 3172 \\
\hline$R^{2}$ & 0.538 & 0.023 & 0.013 & 0.130 & 0.043 & 0.608 & 0.364 & 0.167 \\
\hline
\end{tabular}

Notes: This table presents estimates of Equation (3), including covariates but not fixed effects. The dependent variable is the labour share of value added. The specification estimated is: $\log w_{j, t}^{i}=\gamma_{g}^{i}+X_{j, t}^{\prime} \beta^{i}+\varepsilon_{j, t}^{i}$. The data from the CPS and BEA are merged at the state geographic level and one-digit industry code as described in Appendix A. The generation variables are all dummy variables defined on the basis of date of birth, as per Table 1 . The omitted category is the Silent Generation. $X$ contains education, race, gender, and age variables. Standard errors are in Parenthesis. ${ }^{* * *}$ Significant at the $1 \%$ level. ${ }^{* *}$ Significant at the $5 \%$ level. ${ }^{*}$ Significant at the $10 \%$ level. 
Table B.7: Generational differences in labour share by industry: Including covariates and occupation fixed effects

\begin{tabular}{|c|c|c|c|c|c|c|c|c|}
\hline & $\begin{array}{c}(1) \\
\text { Retail } \\
\beta / \mathrm{SE}\end{array}$ & $\begin{array}{c}(2) \\
\text { Wholesale } \\
\beta / \mathrm{SE}\end{array}$ & $\begin{array}{c}(3) \\
\text { Services } \\
\beta / \mathrm{SE}\end{array}$ & $\begin{array}{c}(4) \\
\text { Finance } \\
\beta / \mathrm{SE}\end{array}$ & $\begin{array}{c}(5) \\
\text { Utilities } \\
\beta / \mathrm{SE}\end{array}$ & $\begin{array}{c}(6) \\
\text { Manufacturing } \\
\beta / \mathrm{SE}\end{array}$ & $\begin{array}{c}(7) \\
\text { Construction } \\
\beta / \mathrm{SE}\end{array}$ & $\begin{array}{c}(8) \\
\text { Mining } \\
\beta / \mathrm{SE}\end{array}$ \\
\hline Baby Boomers & $\begin{array}{l}-0.007^{* * *} \\
(0.000)\end{array}$ & $\begin{array}{ll}-0.000^{* *} \\
(0.000)\end{array}$ & $\begin{array}{l}0.004^{* * *} \\
(0.000)\end{array}$ & $\begin{array}{l}0.156^{* * *} \\
(0.008)\end{array}$ & $\begin{array}{l}0.130^{* * *} \\
(0.008)\end{array}$ & $\begin{array}{l}-0.057^{* * *} \\
(0.000)\end{array}$ & $\begin{array}{l}-0.013^{* * *} \\
(0.000)\end{array}$ & $\begin{array}{l}-0.022^{* * *} * \\
(0.004)\end{array}$ \\
\hline Gen. X. & $\begin{array}{l}-0.014^{* * *} \\
(0.000)\end{array}$ & $\begin{array}{l}-0.001^{* * *} \\
(0.000)\end{array}$ & $\begin{array}{l}0.006^{* * *} \\
(0.000)\end{array}$ & $\begin{array}{l}0.304^{* * *} \\
(0.009)\end{array}$ & $\begin{array}{l}0.257^{* * *} \\
(0.008)\end{array}$ & $\begin{array}{l}-0.107^{* * *} \\
(0.001)\end{array}$ & $\begin{array}{l}-0.025^{* * *} \\
(0.000)\end{array}$ & $\begin{array}{l}-0.052^{* * *} \\
(0.005)\end{array}$ \\
\hline Millennials & $\begin{array}{l}-0.019^{* * *} \\
(0.000)\end{array}$ & $\begin{array}{l}-0.003^{* * *} \\
(0.000)\end{array}$ & $\begin{array}{l}0.007^{* * *} \\
(0.000)\end{array}$ & $\begin{array}{l}0.393^{* * *} \\
(0.011)\end{array}$ & $\begin{array}{l}0.288^{* * *} \\
(0.010)\end{array}$ & $\begin{array}{l}-0.131^{* * *} \\
(0.001)\end{array}$ & $\begin{array}{l}-0.034^{* * *} \\
(0.000)\end{array}$ & $\begin{array}{l}-0.066^{* * *} \\
(0.006)\end{array}$ \\
\hline Age & $\begin{array}{l}-0.001^{* * *} \\
(0.000)\end{array}$ & $\begin{array}{l}-0.000^{* *} \\
(0.000)\end{array}$ & $\begin{array}{l}0.000^{* * *} \\
(0.000)\end{array}$ & $\begin{array}{l}0.015^{* * *} \\
(0.001)\end{array}$ & $\begin{array}{l}0.006^{* * *} \\
(0.002)\end{array}$ & $\begin{array}{l}-0.003^{* * *} \\
(0.000)\end{array}$ & $\begin{array}{l}-0.001^{* * *} \\
(0.000)\end{array}$ & $\begin{array}{l}-0.000 \\
(0.001)\end{array}$ \\
\hline Age Sq & $\begin{array}{l}0.000^{* * *} \\
(0.000)\end{array}$ & $\begin{array}{c}0.000 \\
(0.000)\end{array}$ & $\begin{array}{c}0.000 \\
(0.000)\end{array}$ & $\begin{array}{l}-0.000^{* * *} \\
(0.000)\end{array}$ & $\begin{array}{c}0.000 \\
(0.000)\end{array}$ & $\begin{array}{l}0.000^{* * *} \\
(0.000)\end{array}$ & $\begin{array}{c}0.000 \\
(0.000)\end{array}$ & $\begin{array}{l}-0.000 \\
(0.000)\end{array}$ \\
\hline African American & $\begin{array}{l}-0.000 * * * \\
(0.000)\end{array}$ & $\begin{array}{l}-0.000 \\
(0.000)\end{array}$ & $\begin{array}{l}-0.000^{* *} \\
(0.000)\end{array}$ & $\begin{array}{l}0.014^{* *} \\
(0.006)\end{array}$ & $\begin{array}{l}-0.005 \\
(0.004)\end{array}$ & $\begin{array}{l}-0.005^{* * *} \\
(0.000)\end{array}$ & $\begin{array}{l}-0.001^{* * *} \\
(0.000)\end{array}$ & $\begin{array}{l}-0.002 \\
(0.007)\end{array}$ \\
\hline Hispanic & $\begin{array}{l}-0.000^{* * *} \\
(0.000)\end{array}$ & $\begin{array}{l}-0.000 * * * \\
(0.000)\end{array}$ & $\begin{array}{l}-0.001^{* * *} \\
(0.000)\end{array}$ & $\begin{array}{l}-0.027^{* * *} \\
(0.005)\end{array}$ & $\begin{array}{c}0.007 \\
(0.006)\end{array}$ & $\begin{array}{l}-0.010^{* * *} \\
(0.000)\end{array}$ & $\begin{array}{l}-0.006^{* * *} \\
(0.000)\end{array}$ & $\begin{array}{l}-0.026^{* * *} \\
(0.003)\end{array}$ \\
\hline High School Graduate & $\begin{array}{l}-0.000^{* * *} \\
(0.000)\end{array}$ & $\begin{array}{l}0.001^{* * *} \\
(0.000)\end{array}$ & $\begin{array}{l}0.000^{* *} \\
(0.000)\end{array}$ & $\begin{array}{c}0.006 \\
(0.010)\end{array}$ & $\begin{array}{l}-0.009 \\
(0.008)\end{array}$ & $\begin{array}{l}-0.029^{* * *} \\
(0.000)\end{array}$ & $\begin{array}{l}-0.004^{* * *} \\
(0.000)\end{array}$ & $\begin{array}{l}-0.025^{* * *} \\
(0.004)\end{array}$ \\
\hline College & $\begin{array}{c}0.000^{*} \\
(0.000)\end{array}$ & $\begin{array}{l}0.000^{* * *} \\
(0.000)\end{array}$ & $\begin{array}{l}0.000^{* *} \\
(0.000)\end{array}$ & $\begin{array}{l}0.014^{* * *} \\
(0.004)\end{array}$ & $\begin{array}{l}0.019^{* * *} \\
(0.007)\end{array}$ & $\begin{array}{l}-0.007^{* * *} \\
(0.000)\end{array}$ & $\begin{array}{l}-0.000 \\
(0.000)\end{array}$ & $\begin{array}{l}-0.003 \\
(0.003)\end{array}$ \\
\hline Female & $\begin{array}{l}-0.000^{* *} \\
(0.000)\end{array}$ & $\begin{array}{l}0.000^{* * *} \\
(0.000)\end{array}$ & $\begin{array}{c}0.000 \\
(0.000)\end{array}$ & $\begin{array}{l}-0.006 \\
(0.004)\end{array}$ & $\begin{array}{l}-0.009 \\
(0.006)\end{array}$ & $\begin{array}{l}-0.002^{* * *} \\
(0.000)\end{array}$ & $\begin{array}{l}-0.001^{* *} \\
(0.000)\end{array}$ & $\begin{array}{c}0.001 \\
(0.003)\end{array}$ \\
\hline Technical Sales \& Administrative Support & $\begin{array}{l}-0.000 \\
(0.000)\end{array}$ & $\begin{array}{l}0.000^{* * *} \\
(0.000)\end{array}$ & $\begin{array}{l}-0.000 \\
(0.000)\end{array}$ & $\begin{array}{l}-0.004 \\
(0.004)\end{array}$ & $\begin{array}{l}0.022^{* * *} \\
(0.008)\end{array}$ & $\begin{array}{l}-0.003^{* * *} \\
(0.000)\end{array}$ & $\begin{array}{l}0.001^{* * *} \\
(0.000)\end{array}$ & $\begin{array}{c}0.001 \\
(0.003)\end{array}$ \\
\hline Service & $\begin{array}{c}0.000 \\
(0.000)\end{array}$ & $\begin{array}{c}0.001^{*} \\
(0.000)\end{array}$ & $\begin{array}{l}-0.000 \\
(0.000)\end{array}$ & $\begin{array}{c}0.018^{*} \\
(0.010)\end{array}$ & $\begin{array}{c}0.006 \\
(0.012)\end{array}$ & $\begin{array}{l}-0.012^{\text {*** }} \\
(0.001)\end{array}$ & $\begin{array}{c}0.001 \\
(0.001)\end{array}$ & $\begin{array}{c}0.007 \\
(0.010)\end{array}$ \\
\hline Farming, Forestry \& Fishing & $\begin{array}{l}-0.000 \\
(0.001)\end{array}$ & $\begin{array}{l}0.001^{* * *} \\
(0.000)\end{array}$ & $\begin{array}{c}0.001 \\
(0.001)\end{array}$ & $\begin{array}{l}-0.067^{* * *} \\
(0.023)\end{array}$ & $\begin{array}{l}-0.048^{* * *} \\
(0.018)\end{array}$ & $\begin{array}{l}-0.017^{* * *} \\
(0.002)\end{array}$ & $\begin{array}{l}-0.004^{*} \\
(0.002)\end{array}$ & $\begin{array}{l}0.010^{* *} \\
(0.005)\end{array}$ \\
\hline Precision Production, Craft \& Repair & $\begin{array}{l}-0.000^{* *} \\
(0.000)\end{array}$ & $\begin{array}{l}0.001^{* * *} \\
(0.000)\end{array}$ & $\begin{array}{l}-0.000^{*} \\
(0.000)\end{array}$ & $\begin{array}{l}-0.001 \\
(0.010)\end{array}$ & $\begin{array}{l}-0.003 \\
(0.007)\end{array}$ & $\begin{array}{l}-0.010^{* * *} \\
(0.000)\end{array}$ & $\begin{array}{l}0.000 \\
(0.000)\end{array}$ & $\begin{array}{l}0.008^{* *} \\
(0.003)\end{array}$ \\
\hline Operators, Fabricators \& Labourers & $\begin{array}{c}0.000 \\
(0.000)\end{array}$ & $\begin{array}{l}0.001^{* * *} \\
(0.000)\end{array}$ & $\begin{array}{c}0.000 \\
(0.000)\end{array}$ & $\begin{array}{c}0.014 \\
(0.020)\end{array}$ & $\begin{array}{l}-0.003 \\
(0.006)\end{array}$ & $\begin{array}{l}-0.012^{* * *} \\
(0.000)\end{array}$ & $\begin{array}{l}0.000 \\
(0.000)\end{array}$ & $\begin{array}{l}0.014^{* * *} \\
(0.004)\end{array}$ \\
\hline Constant & $\begin{array}{l}0.060^{* * *} \\
(0.000)\end{array}$ & $\begin{array}{l}0.018^{* * *} \\
(0.000)\end{array}$ & $\begin{array}{l}0.118^{* * *} \\
(0.001)\end{array}$ & $\begin{array}{l}-0.335^{* * *} \\
(0.033)\end{array}$ & $\begin{array}{l}-0.214^{\text {*** }} \\
(0.039)\end{array}$ & $\begin{array}{l}0.290^{* * *} \\
(0.002)\end{array}$ & $\begin{array}{l}0.118^{* * *} \\
(0.001)\end{array}$ & $\begin{array}{l}0.144^{* * *} \\
(0.022)\end{array}$ \\
\hline Observations & 57739 & 14158 & 120231 & 13102 & 20827 & 73359 & 27138 & 3172 \\
\hline$R^{2}$ & 0.538 & 0.027 & 0.013 & 0.131 & 0.044 & 0.615 & 0.365 & 0.172 \\
\hline
\end{tabular}

Notes: This table presents estimates of Equation (3), including covariates and occupation fixed effects. The dependent variable is the labour share of value added. The specification estimated is: $\log w_{j, t}^{i}=\gamma_{g}^{i}+X_{j, t}^{\prime} \beta^{i}+\varepsilon_{j, t}^{i}$. The data from the CPS and BEA are merged at the state geographic level and one-digit industry code as described in Appendix A. The generation variables are all dummy variables defined on the basis of date of birth, as per Table 1. The omitted category is the Silent Generation and Managerial \& Professional Speciality. $X$ contains education, race, gender, and age variables. Standard errors are in Parenthesis. ${ }^{* * *}$ Significant at the $1 \%$ level. ${ }^{* *}$ Significant at the $5 \%$ level. ${ }^{*}$ Significant at the $10 \%$ level. 
Table B.8: Generational differences in labour share by industry: Including covariates and state fixed effects

\begin{tabular}{|c|c|c|c|c|c|c|c|c|}
\hline & $\begin{array}{c}(1) \\
\text { Retail } \\
\beta / \mathrm{SE}\end{array}$ & $\begin{array}{c}(2) \\
\text { Wholesale } \\
\beta / \mathrm{SE}\end{array}$ & $\begin{array}{c}(3) \\
\text { Services } \\
\beta / \mathrm{SE}\end{array}$ & $\begin{array}{c}(4) \\
\text { Finance } \\
\beta / \mathrm{SE}\end{array}$ & $\begin{array}{c}(5) \\
\text { Utilities } \\
\beta / \mathrm{SE}\end{array}$ & $\begin{array}{c}(6) \\
\text { Manufacturing } \\
\beta / \mathrm{SE}\end{array}$ & $\begin{array}{c}(7) \\
\text { Construction } \\
\beta / \mathrm{SE}\end{array}$ & $\begin{array}{c}(8) \\
\text { Mining } \\
\beta / \mathrm{SE}\end{array}$ \\
\hline Baby Boomers & $\begin{array}{l}-0.007^{* * *} \\
(0.000)\end{array}$ & $\begin{array}{l}-0.000 \\
(0.000)\end{array}$ & $\begin{array}{l}0.004^{* * *} \\
(0.001)\end{array}$ & $\begin{array}{l}0.170^{\text {*** }} \\
(0.020)\end{array}$ & $\begin{array}{l}0.127^{* * *} \\
(0.014)\end{array}$ & $\begin{array}{l}-0.056^{* * *} \\
(0.002)\end{array}$ & $\begin{array}{l}-0.013^{* * *} \\
(0.001)\end{array}$ & $\begin{array}{l}-0.026^{* * *} \\
(0.005)\end{array}$ \\
\hline Gen. X. & $\begin{array}{l}-0.014^{* * *} \\
(0.000)\end{array}$ & $\begin{array}{l}-0.001^{*} \\
(0.001)\end{array}$ & $\begin{array}{l}0.006^{* * *} \\
(0.002)\end{array}$ & $\begin{array}{l}0.319^{* * *} \\
(0.034)\end{array}$ & $\begin{array}{l}0.245^{* * *} \\
(0.027)\end{array}$ & $\begin{array}{l}-0.105^{* * *} \\
(0.003)\end{array}$ & $\begin{array}{l}-0.025^{* * *} \\
(0.001)\end{array}$ & $\begin{array}{l}-0.055^{* * *} \\
(0.011)\end{array}$ \\
\hline Millennials & $\begin{array}{l}-0.019^{* * *} \\
(0.000)\end{array}$ & $\begin{array}{l}-0.003^{* * *} \\
(0.001)\end{array}$ & $\begin{array}{l}0.008^{* * *} \\
(0.003)\end{array}$ & $\begin{array}{l}0.400^{* * * *} \\
(0.041)\end{array}$ & $\begin{array}{l}0.274^{* * *} \\
(0.054)\end{array}$ & $\begin{array}{l}-0.129^{* * *} \\
(0.003)\end{array}$ & $\begin{array}{l}-0.034^{* * *} \\
(0.002)\end{array}$ & $\begin{array}{l}-0.066^{* * *} \\
(0.016)\end{array}$ \\
\hline Age & $\begin{array}{l}-0.001^{* * *} \\
(0.000)\end{array}$ & $\begin{array}{l}-0.000^{* *} \\
(0.000)\end{array}$ & $\begin{array}{c}0.000^{*} \\
(0.000)\end{array}$ & $\begin{array}{l}0.013^{* * *} \\
(0.002)\end{array}$ & $\begin{array}{r}0.005^{*} \\
(0.003)\end{array}$ & $\begin{array}{l}-0.003^{* * *} \\
(0.000)\end{array}$ & $\begin{array}{l}-0.001^{* * *} \\
(0.000)\end{array}$ & $\begin{array}{l}-0.001 \\
(0.001)\end{array}$ \\
\hline Age Sq & $\begin{array}{l}0.000^{* * *} \\
(0.000)\end{array}$ & $\begin{array}{c}0.000 \\
(0.000)\end{array}$ & $\begin{array}{c}0.000 \\
(0.000)\end{array}$ & $\begin{array}{l}-0.000^{* * * *} \\
(0.000)\end{array}$ & $\begin{array}{c}0.000 \\
(0.000)\end{array}$ & $\begin{array}{l}0.000^{* * *} \\
(0.000)\end{array}$ & $\begin{array}{l}0.000^{* * *} \\
(0.000)\end{array}$ & $\begin{array}{l}-0.000 \\
(0.000)\end{array}$ \\
\hline African American & $\begin{array}{l}-0.000^{* * *} \\
(0.000)\end{array}$ & $\begin{array}{c}0.000 \\
(0.000)\end{array}$ & $\begin{array}{c}0.000 \\
(0.000)\end{array}$ & $\begin{array}{l}0.019^{* * *} \\
(0.005)\end{array}$ & $\begin{array}{c}0.004 \\
(0.005)\end{array}$ & $\begin{array}{l}-0.001 \\
(0.000)\end{array}$ & $\begin{array}{c}0.000 \\
(0.000)\end{array}$ & $\begin{array}{c}0.003 \\
(0.004)\end{array}$ \\
\hline Hispanic & $\begin{array}{l}-0.001^{* * *} \\
(0.000)\end{array}$ & $\begin{array}{c}0.000 \\
(0.000)\end{array}$ & $\begin{array}{l}0.001^{* * *} \\
(0.000)\end{array}$ & $\begin{array}{c}0.009^{*} \\
(0.004)\end{array}$ & $\begin{array}{c}0.003 \\
(0.007)\end{array}$ & $\begin{array}{l}-0.012^{* * *} \\
(0.001)\end{array}$ & $\begin{array}{l}-0.002^{* * *} \\
(0.000)\end{array}$ & $\begin{array}{l}-0.005 \\
(0.003)\end{array}$ \\
\hline High School Graduate & $\begin{array}{l}-0.001^{\text {*** }} \\
(0.000)\end{array}$ & $\begin{array}{l}0.001^{* * *} \\
(0.000)\end{array}$ & $\begin{array}{c}0.000 \\
(0.000)\end{array}$ & $\begin{array}{l}-0.011^{*} \\
(0.006)\end{array}$ & $\begin{array}{l}-0.009 \\
(0.007)\end{array}$ & $\begin{array}{l}-0.030^{* * *} \\
(0.002)\end{array}$ & $\begin{array}{l}-0.004^{* * *} \\
(0.001)\end{array}$ & $\begin{array}{l}-0.020^{* * *} \\
(0.005)\end{array}$ \\
\hline College & $\begin{array}{l}-0.000 \\
(0.000)\end{array}$ & $\begin{array}{l}0.000^{* * *} \\
(0.000)\end{array}$ & $\begin{array}{c}0.000 \\
(0.000)\end{array}$ & $\begin{array}{c}0.004 \\
(0.004)\end{array}$ & $\begin{array}{c}0.010 \\
(0.009)\end{array}$ & $\begin{array}{l}-0.008^{* * *} \\
(0.000)\end{array}$ & $\begin{array}{c}0.000 \\
(0.000)\end{array}$ & $\begin{array}{l}-0.003 \\
(0.002)\end{array}$ \\
\hline Female & $\begin{array}{c}0.000 \\
(0.000)\end{array}$ & $\begin{array}{l}0.000^{* * * *} \\
(0.000)\end{array}$ & $\begin{array}{l}-0.000 \\
(0.000)\end{array}$ & $\begin{array}{l}-0.002 \\
(0.004)\end{array}$ & $\begin{array}{l}-0.009 \\
(0.006)\end{array}$ & $\begin{array}{l}-0.002^{* * *} \\
(0.000)\end{array}$ & $\begin{array}{l}-0.001^{* *} \\
(0.000)\end{array}$ & $\begin{array}{l}-0.001 \\
(0.003)\end{array}$ \\
\hline Technical Sales \& Administrative Support & $\begin{array}{l}-0.000 \\
(0.000)\end{array}$ & $\begin{array}{l}0.000^{* * *} \\
(0.000)\end{array}$ & $\begin{array}{l}-0.000 \\
(0.000)\end{array}$ & $\begin{array}{l}-0.006 \\
(0.003)\end{array}$ & $\begin{array}{c}0.017 \\
(0.014)\end{array}$ & $\begin{array}{l}-0.003^{* * *} \\
(0.000)\end{array}$ & $\begin{array}{c}0.001 \\
(0.000)\end{array}$ & $\begin{array}{l}-0.002 \\
(0.003)\end{array}$ \\
\hline Service & $\begin{array}{l}-0.000 \\
(0.000)\end{array}$ & $\begin{array}{c}0.000 \\
(0.000)\end{array}$ & $\begin{array}{c}0.000 \\
(0.000)\end{array}$ & $\begin{array}{l}-0.005 \\
(0.009)\end{array}$ & $\begin{array}{l}-0.013 \\
(0.014)\end{array}$ & $\begin{array}{l}-0.010^{* * *} \\
(0.001)\end{array}$ & $\begin{array}{c}-0.000 \\
(0.001)\end{array}$ & $\begin{array}{l}-0.010 \\
(0.006)\end{array}$ \\
\hline Farming, Forestry \& Fishing & $\begin{array}{l}-0.000 \\
(0.001)\end{array}$ & $\begin{array}{c}0.001^{*} \\
(0.000)\end{array}$ & $\begin{array}{l}0.002^{\text {**** }} \\
(0.000)\end{array}$ & $\begin{array}{l}-0.042^{* *} \\
(0.019)\end{array}$ & $\begin{array}{l}-0.066 \\
(0.050)\end{array}$ & $\begin{array}{l}-0.013^{* * *} \\
(0.002)\end{array}$ & $\begin{array}{l}-0.004^{*} \\
(0.002)\end{array}$ & $\begin{array}{l}-0.023 \\
(0.015)\end{array}$ \\
\hline Precision Production, Craft \& Repair & $\begin{array}{l}-0.000^{* *} \\
(0.000)\end{array}$ & $\begin{array}{l}0.001^{* * *} \\
(0.000)\end{array}$ & $\begin{array}{c}-0.000 \\
(0.000)\end{array}$ & $\begin{array}{l}-0.001 \\
(0.010)\end{array}$ & $\begin{array}{c}0.002 \\
(0.004)\end{array}$ & $\begin{array}{l}-0.008^{* * *} \\
(0.001)\end{array}$ & $\begin{array}{l}-0.001^{* * *} \\
(0.000)\end{array}$ & $\begin{array}{l}-0.003 \\
(0.002)\end{array}$ \\
\hline Operators, Fabricators \& Labourers & $\begin{array}{c}0.000 \\
(0.000)\end{array}$ & $\begin{array}{l}0.000^{* * *} \\
(0.000)\end{array}$ & $\begin{array}{l}-0.000 \\
(0.000)\end{array}$ & $\begin{array}{c}0.018 \\
(0.011)\end{array}$ & $\begin{array}{c}0.002 \\
(0.005)\end{array}$ & $\begin{array}{l}-0.010^{* * *} \\
(0.001)\end{array}$ & $\begin{array}{l}-0.001^{* * *} \\
(0.000)\end{array}$ & $\begin{array}{l}-0.005 \\
(0.003)\end{array}$ \\
\hline Constant & $\begin{array}{l}0.060^{\text {*** }} \\
(0.001)\end{array}$ & $\begin{array}{l}0.019^{\text {*** }} \\
(0.001)\end{array}$ & $\begin{array}{l}0.118^{* * *} \\
(0.003)\end{array}$ & $\begin{array}{l}-0.299^{* * *} \\
(0.075)\end{array}$ & $\begin{array}{l}-0.178^{*} \\
(0.089)\end{array}$ & $\begin{array}{l}0.286^{* * *} \\
(0.006)\end{array}$ & $\begin{array}{l}0.120^{* * *} \\
(0.003)\end{array}$ & $\begin{array}{l}0.166^{* * * *} \\
(0.025)\end{array}$ \\
\hline Observations & 57739 & 14158 & 120231 & 13102 & 20827 & 73359 & 27138 & 3171 \\
\hline$R^{2}$ & 0.600 & 0.537 & 0.155 & 0.486 & 0.215 & 0.669 & 0.542 & 0.558 \\
\hline
\end{tabular}

Notes: This table presents estimates of Equation (3), including covariates and state fixed effects. The dependent variable is the labour share of value added. The specification estimated is: $\log w_{j, t}^{i}=\gamma_{g}^{i}+X_{j, t}^{\prime} \beta^{i}+\delta_{s}^{i}+\varepsilon_{j, t}^{i} \cdot \varepsilon_{j, t}^{i}$ is clustered by state. The data from the CPS and BEA are merged at the state geographic level and one-digit industry code as described in Appendix A. The generation variables are all dummy variables defined on the basis of date of birth, as per Table 1 . The omitted category is the Silent Generation. $X$ contains education, race, gender, and age variables. Standard errors are in parentheis. ${ }^{* * *}$ Significant at the $1 \%$ level. ${ }^{* *}$ Significant at the $5 \%$ level. ${ }^{*}$ Significant at the $10 \%$ level. 
Table B.9: Wage regressions by generation

\begin{tabular}{|c|c|c|c|c|c|c|c|c|c|c|c|c|}
\hline & $\begin{array}{c}(1) \\
\text { Silent } \\
\beta / \mathrm{SE}\end{array}$ & $\begin{array}{c}(2) \\
\text { Boomer's } \\
\beta / \mathrm{SE}\end{array}$ & $\begin{array}{c}(3) \\
\text { Gen. } \boldsymbol{X} \\
\beta / \mathrm{SE}\end{array}$ & $\begin{array}{c}(4) \\
\text { Millenials } \\
\beta / \mathrm{SE}\end{array}$ & $\begin{array}{c}(5) \\
\text { Silent } \\
\beta / \mathrm{SE}\end{array}$ & $\begin{array}{c}(6) \\
\text { Boomer's } \\
\beta / \mathrm{SE}\end{array}$ & $\begin{array}{c}(7) \\
\text { Gen. } \boldsymbol{X} \\
\beta / \mathrm{SE}\end{array}$ & $\begin{array}{c}(8) \\
\text { Millenials } \\
\beta / \mathrm{SE}\end{array}$ & $\begin{array}{c}(9) \\
\text { Silent } \\
\beta / \mathrm{SE}\end{array}$ & $\begin{array}{c}(10) \\
\text { Boomer's } \\
\beta / \mathrm{SE}\end{array}$ & $\begin{array}{c}(11) \\
\text { Gen. } \boldsymbol{X} \\
\beta / \mathrm{SE}\end{array}$ & $\begin{array}{c}(12) \\
\text { Millenials } \\
\beta / \mathrm{SE}\end{array}$ \\
\hline Age & $\begin{array}{l}0.109^{* * *} \\
(0.006)\end{array}$ & $\begin{array}{l}0.057^{* * *} \\
(0.002)\end{array}$ & $\begin{array}{l}0.145^{* * *} \\
(0.005)\end{array}$ & $\begin{array}{l}0.415^{* * * *} \\
(0.044)\end{array}$ & $\begin{array}{l}0.077^{* * *} \\
(0.006)\end{array}$ & $\begin{array}{l}0.050^{* * *} \\
(0.002)\end{array}$ & $\begin{array}{l}0.141^{* * *} \\
(0.005)\end{array}$ & $\begin{array}{l}0.375^{* * *} \\
(0.043)\end{array}$ & $\begin{array}{l}0.074^{* * *} \\
(0.005)\end{array}$ & $\begin{array}{l}0.055^{* * *} \\
(0.002)\end{array}$ & $\begin{array}{l}0.131^{* * * *} \\
(0.004)\end{array}$ & $\begin{array}{l}0.375^{* * *} \\
(0.041)\end{array}$ \\
\hline Age Sq & $\begin{array}{l}-0.001^{* * * *} \\
(0.000)\end{array}$ & $\begin{array}{l}-0.001^{* * * *} \\
(0.000)\end{array}$ & $\begin{array}{l}-0.002^{* * * *} \\
(0.000)\end{array}$ & $\begin{array}{l}-0.007^{* * * *} \\
(0.001)\end{array}$ & $\begin{array}{l}-0.001^{* * *} \\
(0.000)\end{array}$ & $\begin{array}{l}-0.001^{* * * *} \\
(0.000)\end{array}$ & $\begin{array}{l}-0.002^{\text {*** }} \\
(0.000)\end{array}$ & $\begin{array}{l}-0.006^{* * *} \\
(0.001)\end{array}$ & $\begin{array}{l}-0.001^{* * * *} \\
(0.000)\end{array}$ & $\begin{array}{l}-0.001^{* * * *} \\
(0.000)\end{array}$ & $\begin{array}{l}-0.002^{* * * *} \\
(0.000)\end{array}$ & $\begin{array}{l}-0.006^{* * * *} \\
(0.001)\end{array}$ \\
\hline African American & $\begin{array}{l}-0.204^{* * *} \\
(0.013)\end{array}$ & $\begin{array}{l}-0.214^{* * *} \\
(0.008)\end{array}$ & $\begin{array}{l}-0.172^{* * *} \\
(0.009)\end{array}$ & $\begin{array}{l}-0.189^{* * *} \\
(0.019)\end{array}$ & $\begin{array}{l}-0.200^{* * *} \\
(0.013)\end{array}$ & $\begin{array}{l}-0.218^{* * * *} \\
(0.007)\end{array}$ & $\begin{array}{l}-0.172^{* * *} \\
(0.009)\end{array}$ & $\begin{array}{l}-0.185^{* * *} \\
(0.019)\end{array}$ & $\begin{array}{l}-0.074^{* * *} \\
(0.013)\end{array}$ & $\begin{array}{l}-0.125^{* * *} \\
(0.007)\end{array}$ & $\begin{array}{l}-0.117^{* * *} \\
(0.009)\end{array}$ & $\begin{array}{l}-0.150^{* * * *} \\
(0.018)\end{array}$ \\
\hline Hispanic & $\begin{array}{l}-0.223^{* * *} \\
(0.013)\end{array}$ & $\begin{array}{l}-0.222^{* * * *} \\
(0.007)\end{array}$ & $\begin{array}{l}-0.136^{* * *} \\
(0.007)\end{array}$ & $\begin{array}{l}-0.085^{* * *} \\
(0.014)\end{array}$ & $\begin{array}{l}-0.222^{\text {*** }} \\
(0.013)\end{array}$ & $\begin{array}{l}-0.214^{* * * *} \\
(0.007)\end{array}$ & $\begin{array}{l}-0.134^{* * *} \\
(0.007)\end{array}$ & $\begin{array}{l}-0.088^{* * *} \\
(0.014)\end{array}$ & $\begin{array}{l}-0.129^{* * *} \\
(0.013)\end{array}$ & $\begin{array}{l}-0.136^{* * * *} \\
(0.006)\end{array}$ & $\begin{array}{l}-0.087^{* * *} \\
(0.007)\end{array}$ & $\begin{array}{l}-0.069^{* * * *} \\
(0.013)\end{array}$ \\
\hline High School Graduate & $\begin{array}{l}0.279^{* * *} \\
(0.008)\end{array}$ & $\begin{array}{l}0.283^{* * *} \\
(0.006)\end{array}$ & $\begin{array}{l}0.386^{* * *} \\
(0.010)\end{array}$ & $\begin{array}{l}0.367^{* * *} \\
(0.020)\end{array}$ & $\begin{array}{l}0.291^{* * *} \\
(0.008)\end{array}$ & $\begin{array}{l}0.294^{* * *} \\
(0.006)\end{array}$ & $\begin{array}{l}0.377^{* * *} \\
(0.010)\end{array}$ & $\begin{array}{l}0.363^{* * *} \\
(0.020)\end{array}$ & $\begin{array}{l}0.139^{* * *} \\
(0.008)\end{array}$ & $\begin{array}{l}0.162^{* * *} \\
(0.006)\end{array}$ & $\begin{array}{l}0.278^{* * * *} \\
(0.010)\end{array}$ & $\begin{array}{l}0.300^{* * *} \\
(0.020)\end{array}$ \\
\hline College & $\begin{array}{l}0.424^{* * * *} \\
(0.014)\end{array}$ & $\begin{array}{l}0.511^{* * *} \\
(0.006)\end{array}$ & $\begin{array}{l}0.550^{* * *} \\
(0.007)\end{array}$ & $\begin{array}{l}0.495^{* * *} \\
(0.013)\end{array}$ & $\begin{array}{l}0.444^{* * *} \\
(0.014)\end{array}$ & $\begin{array}{l}0.508^{* * *} \\
(0.006)\end{array}$ & $\begin{array}{l}0.534^{* * * *} \\
(0.007)\end{array}$ & $\begin{array}{l}0.477^{* * *} \\
(0.013)\end{array}$ & $\begin{array}{l}0.233^{* * *} \\
(0.014)\end{array}$ & $\begin{array}{l}0.289^{* * *} \\
(0.006)\end{array}$ & $\begin{array}{l}0.333^{* * * *} \\
(0.007)\end{array}$ & $\begin{array}{l}0.326^{* * * *} \\
(0.014)\end{array}$ \\
\hline Female & $\begin{array}{l}-0.708^{* * *} \\
(0.008)\end{array}$ & $\begin{array}{l}-0.502^{* * * *} \\
(0.004)\end{array}$ & $\begin{array}{l}-0.407^{* * * *} \\
(0.006)\end{array}$ & $\begin{array}{l}-0.265^{* * *} \\
(0.011)\end{array}$ & $\begin{array}{l}-0.614^{* * * *} \\
(0.008)\end{array}$ & $\begin{array}{l}-0.451^{* * * *} \\
(0.005)\end{array}$ & $\begin{array}{l}-0.372^{\text {**** }} \\
(0.006)\end{array}$ & $\begin{array}{l}-0.217^{* * *} \\
(0.012)\end{array}$ & $\begin{array}{l}-0.592^{* * *} \\
(0.009)\end{array}$ & $\begin{array}{l}-0.465^{* * *} \\
(0.005)\end{array}$ & $\begin{array}{l}-0.394^{* * *} \\
(0.006)\end{array}$ & $\begin{array}{l}-0.223^{* * *} \\
(0.012)\end{array}$ \\
\hline Wholesale Trade & & & & & $\begin{array}{l}0.409^{* * *} \\
(0.018)\end{array}$ & $\begin{array}{l}0.396^{* * *} \\
(0.011)\end{array}$ & $\begin{array}{l}0.368^{* * *} \\
(0.014)\end{array}$ & $\begin{array}{l}0.356^{* * *} \\
(0.033)\end{array}$ & $\begin{array}{l}0.381^{* * *} \\
(0.017)\end{array}$ & $\begin{array}{l}0.374^{* * *} \\
(0.011)\end{array}$ & $\begin{array}{l}0.350^{* * * *} \\
(0.014)\end{array}$ & $\begin{array}{l}0.336^{* * *} \\
(0.033)\end{array}$ \\
\hline Services & & & & & $\begin{array}{l}0.167^{* * *} \\
(0.012)\end{array}$ & $\begin{array}{l}0.218^{* * *} \\
(0.007)\end{array}$ & $\begin{array}{l}0.199^{* * * *} \\
(0.009)\end{array}$ & $\begin{array}{l}0.206^{* * *} \\
(0.015)\end{array}$ & $\begin{array}{l}0.148^{* * *} \\
(0.012)\end{array}$ & $\begin{array}{l}0.165^{* * *} \\
(0.007)\end{array}$ & $\begin{array}{l}0.146^{* * * *} \\
(0.008)\end{array}$ & $\begin{array}{l}0.155^{* * *} \\
(0.015)\end{array}$ \\
\hline Finance & & & & & $\begin{array}{l}0.350^{* * * *} \\
(0.029)\end{array}$ & $\begin{array}{l}0.400^{* * *} \\
(0.013)\end{array}$ & $\begin{array}{l}0.393^{* * *} \\
(0.014)\end{array}$ & $\begin{array}{l}0.376^{* * * *} \\
(0.025)\end{array}$ & $\begin{array}{l}0.280^{* * * *} \\
(0.028)\end{array}$ & $\begin{array}{l}0.284^{* * *} \\
(0.012)\end{array}$ & $\begin{array}{l}0.266^{* * * *} \\
(0.013)\end{array}$ & $\begin{array}{l}0.264^{* * * *} \\
(0.025)\end{array}$ \\
\hline Utilities \& Transportation & & & & & $\begin{array}{l}0.365^{* * *} \\
(0.023)\end{array}$ & $\begin{array}{l}0.425^{* * *} \\
(0.010)\end{array}$ & $\begin{array}{l}0.362^{* * *} \\
(0.012)\end{array}$ & $\begin{array}{l}0.369^{* * *} \\
(0.024)\end{array}$ & $\begin{array}{l}0.405^{* * *} \\
(0.022)\end{array}$ & $\begin{array}{l}0.426^{* * *} \\
(0.010)\end{array}$ & $\begin{array}{l}0.354^{* * * *} \\
(0.012)\end{array}$ & $\begin{array}{l}0.331^{* * * *} \\
(0.024)\end{array}$ \\
\hline Manufacturing & & & & & $\begin{array}{l}0.463^{* * *} \\
(0.012)\end{array}$ & $\begin{array}{l}0.431^{* * *} \\
(0.007)\end{array}$ & $\begin{array}{l}0.348^{* * *} \\
(0.009)\end{array}$ & $\begin{array}{l}0.362^{* * *} \\
(0.019)\end{array}$ & $\begin{array}{l}0.457^{* * *} \\
(0.012)\end{array}$ & $\begin{array}{l}0.415^{* * *} \\
(0.007)\end{array}$ & $\begin{array}{l}0.340^{* * * *} \\
(0.009)\end{array}$ & $\begin{array}{l}0.334^{* * * *} \\
(0.020)\end{array}$ \\
\hline Construction & & & & & $\begin{array}{l}0.262^{* * *} \\
(0.017)\end{array}$ & $\begin{array}{l}0.233^{* * *} \\
(0.010)\end{array}$ & $\begin{array}{l}0.243^{* * *} \\
(0.012)\end{array}$ & $\begin{array}{l}0.341^{* * * *} \\
(0.022)\end{array}$ & $\begin{array}{l}0.208^{* * *} \\
(0.018)\end{array}$ & $\begin{array}{l}0.170^{* * *} \\
(0.010)\end{array}$ & $\begin{array}{l}0.194^{* * * *} \\
(0.012)\end{array}$ & $\begin{array}{l}0.241^{* * * *} \\
(0.023)\end{array}$ \\
\hline Mining & & & & & $\begin{array}{l}0.652^{* * *} \\
(0.043)\end{array}$ & $\begin{array}{l}0.582^{* * *} \\
(0.019)\end{array}$ & $\begin{array}{l}0.545^{* * *} \\
(0.029)\end{array}$ & $\begin{array}{l}0.840^{* * *} \\
(0.060)\end{array}$ & $\begin{array}{l}0.609^{* * *} \\
(0.041)\end{array}$ & $\begin{array}{l}0.533^{* * *} \\
(0.018)\end{array}$ & $\begin{array}{l}0.509^{* * * *} \\
(0.029)\end{array}$ & $\begin{array}{l}0.755^{* * *} \\
(0.060)\end{array}$ \\
\hline Technical Sales \& Administrative Support & & & & & & & & & $\begin{array}{l}-0.367^{* * * *} \\
(0.011)\end{array}$ & $\begin{array}{l}-0.334^{* * * *} \\
(0.006)\end{array}$ & $\begin{array}{l}-0.280^{* * * *} \\
(0.008)\end{array}$ & $\begin{array}{l}-0.232^{* * *} \\
(0.016)\end{array}$ \\
\hline Service & & & & & & & & & $\begin{array}{l}-0.778^{* * *} \\
(0.015)\end{array}$ & $\begin{array}{l}-0.737^{* * *} \\
(0.008)\end{array}$ & $\begin{array}{l}-0.635^{* * *} \\
(0.010)\end{array}$ & $\begin{array}{l}-0.509^{* * *} \\
(0.019)\end{array}$ \\
\hline Farming, Forestry \& Fishing & & & & & & & & & $\begin{array}{l}-1.175^{* * * *} \\
(0.062)\end{array}$ & $\begin{array}{l}-0.915^{* * * *} \\
(0.034)\end{array}$ & $\begin{array}{l}-0.635^{* * *} \\
(0.038)\end{array}$ & $\begin{array}{l}-0.776^{* * * *} \\
(0.089)\end{array}$ \\
\hline Precision Production, Craft \& Repair & & & & & & & & & $\begin{array}{l}-0.375^{* * *} \\
(0.013)\end{array}$ & $\begin{array}{l}-0.369^{* * * *} \\
(0.008)\end{array}$ & $\begin{array}{l}-0.335^{* * *} \\
(0.011)\end{array}$ & $\begin{array}{l}-0.165^{* * *} \\
(0.022)\end{array}$ \\
\hline Operators, Fabricators \& Labourers & & & & & & & & & $\begin{array}{l}-0.631^{* * * *} \\
(0.013)\end{array}$ & $\begin{array}{l}-0.625^{* * * *} \\
(0.008)\end{array}$ & $\begin{array}{l}-0.571^{* * *} \\
(0.010)\end{array}$ & $\begin{array}{l}-0.425^{* * * *} \\
(0.022)\end{array}$ \\
\hline Constant & $\begin{array}{l}7.821^{* * * *} \\
(0.135) \\
\end{array}$ & $\begin{array}{l}8.798^{* * *} \\
(0.037)\end{array}$ & $\begin{array}{l}7.034^{* * * *} \\
(0.078)\end{array}$ & $\begin{array}{l}3.298^{* * *} \\
(0.591)\end{array}$ & $\begin{array}{l}8.305^{* * *} \\
(0.134) \\
\end{array}$ & $\begin{array}{l}8.641^{* * *} \\
(0.036) \\
\end{array}$ & $\begin{array}{l}6.898^{* * *} \\
(0.077)\end{array}$ & $\begin{array}{l}3.662^{* * *} \\
(0.578) \\
\end{array}$ & $\begin{array}{l}8.765^{* * * *} \\
(0.129) \\
\end{array}$ & $\begin{array}{l}9.033^{* * *} \\
(0.035) \\
\end{array}$ & $\begin{array}{l}7.566^{* * *} \\
(0.075)\end{array}$ & $\begin{array}{l}4.088^{* * * *} \\
(0.563)\end{array}$ \\
\hline Observations & 51908 & 160577 & 94243 & 23213 & 51908 & 160577 & 94243 & 23213 & 51908 & 160577 & 94243 & 23213 \\
\hline$R^{2}$ & 0.255 & 0.230 & 0.240 & 0.184 & 0.287 & 0.259 & 0.264 & 0.218 & 0.353 & 0.325 & 0.317 & 0.258 \\
\hline
\end{tabular}


Table B.10: Wage regressions by generation with state fixed effects

\begin{tabular}{|c|c|c|c|c|c|c|c|c|c|c|c|c|}
\hline & $\begin{array}{c}(1) \\
\text { Silent } \\
\beta / \mathrm{SE}\end{array}$ & $\begin{array}{c}(2) \\
\text { Boomer's } \\
\beta / \mathrm{SE}\end{array}$ & $\begin{array}{c}(3) \\
\text { Gen. } \boldsymbol{X} \\
\beta / \mathrm{SE}\end{array}$ & $\begin{array}{c}(4) \\
\text { Millenials } \\
\beta / \mathrm{SE}\end{array}$ & $\begin{array}{c}(5) \\
\text { Silent } \\
\beta / \mathrm{SE}\end{array}$ & $\begin{array}{c}(6) \\
\text { Boomer's } \\
\beta / \mathrm{SE}\end{array}$ & $\begin{array}{c}(7) \\
\text { Gen. } \boldsymbol{X} \\
\beta / \mathrm{SE}\end{array}$ & $\begin{array}{c}(8) \\
\text { Millenials } \\
\beta / \mathrm{SE}\end{array}$ & $\begin{array}{c}(9) \\
\text { Silent } \\
\beta / \mathrm{SE}\end{array}$ & $\begin{array}{c}(10) \\
\text { Boomer's } \\
\beta / \mathrm{SE}\end{array}$ & $\begin{array}{c}(11) \\
\text { Gen. } \boldsymbol{X} \\
\beta / \mathrm{SE}\end{array}$ & $\begin{array}{c}(12) \\
\text { Millenials } \\
\beta / \mathrm{SE}\end{array}$ \\
\hline Age & $\begin{array}{l}0.108^{* * *} \\
(0.008)\end{array}$ & $\begin{array}{l}0.058^{* * *} \\
(0.002)\end{array}$ & $\begin{array}{l}0.145^{* * *} \\
(0.004)\end{array}$ & $\begin{array}{l}0.410^{* * * *} \\
(0.038)\end{array}$ & $\begin{array}{l}0.077^{* * *} \\
(0.008)\end{array}$ & $\begin{array}{l}0.050^{* * * *} \\
(0.002)\end{array}$ & $\begin{array}{l}0.141^{* * * *} \\
(0.004)\end{array}$ & $\begin{array}{l}0.370^{* * *} \\
(0.039)\end{array}$ & $\begin{array}{l}0.074^{* * *} \\
(0.008)\end{array}$ & $\begin{array}{l}0.055^{* * *} \\
(0.002)\end{array}$ & $\begin{array}{l}0.131^{* * *} \\
(0.003)\end{array}$ & $\begin{array}{l}0.371^{* * * *} \\
(0.037)\end{array}$ \\
\hline Age Sq & $\begin{array}{l}-0.001^{* * *} \\
(0.000)\end{array}$ & $\begin{array}{l}-0.001^{* * *} \\
(0.000)\end{array}$ & $\begin{array}{l}-0.002^{* * * *} \\
(0.000)\end{array}$ & $\begin{array}{l}-0.007^{* * *} \\
(0.001)\end{array}$ & $\begin{array}{l}-0.001^{* * *} \\
(0.000)\end{array}$ & $\begin{array}{l}-0.001^{* * *} * \\
(0.000)\end{array}$ & $\begin{array}{l}-0.002^{* * *} \\
(0.000)\end{array}$ & $\begin{array}{l}-0.006^{* * * *} \\
(0.001)\end{array}$ & $\begin{array}{l}-0.001^{* * * *} \\
(0.000)\end{array}$ & $\begin{array}{l}-0.001^{* * *} \\
(0.000)\end{array}$ & $\begin{array}{l}-0.002^{* * *} \\
(0.000)\end{array}$ & $\begin{array}{l}-0.006^{* * *} \\
(0.001)\end{array}$ \\
\hline African American & $\begin{array}{l}-0.212^{* * *} \\
(0.029)\end{array}$ & $\begin{array}{l}-0.217^{* * *} \\
(0.013)\end{array}$ & $\begin{array}{l}-0.183^{* * *} \\
(0.012)\end{array}$ & $\begin{array}{l}-0.198^{* * *} \\
(0.016)\end{array}$ & $\begin{array}{l}-0.208^{* * *} \\
(0.028)\end{array}$ & $\begin{array}{l}-0.221^{* * * *} \\
(0.013)\end{array}$ & $\begin{array}{l}-0.183^{* * *} \\
(0.011)\end{array}$ & $\begin{array}{l}-0.194^{* * *} \\
(0.016)\end{array}$ & $\begin{array}{l}-0.078^{* * *} \\
(0.020)\end{array}$ & $\begin{array}{l}-0.125^{* * *} \\
(0.010)\end{array}$ & $\begin{array}{l}-0.126^{* * *} \\
(0.009)\end{array}$ & $\begin{array}{l}-0.156^{* * *} \\
(0.016)\end{array}$ \\
\hline Hispanic & $\begin{array}{l}-0.254^{* * *} \\
(0.026)\end{array}$ & $\begin{array}{l}-0.262^{* * *} \\
(0.014)\end{array}$ & $\begin{array}{l}-0.173^{* * * *} \\
(0.012)\end{array}$ & $\begin{array}{l}-0.123^{* * *} \\
(0.022)\end{array}$ & $\begin{array}{l}-0.262^{* * *} \\
(0.024)\end{array}$ & $\begin{array}{l}-0.258^{* * *} \\
(0.013)\end{array}$ & $\begin{array}{l}-0.173^{* * *} \\
(0.012)\end{array}$ & $\begin{array}{l}-0.126^{* * * *} \\
(0.023)\end{array}$ & $\begin{array}{l}-0.157^{* * *} \\
(0.023)\end{array}$ & $\begin{array}{l}-0.168^{* * *} \\
(0.014)\end{array}$ & $\begin{array}{l}-0.116^{* * * *} \\
(0.013)\end{array}$ & $\begin{array}{l}-0.099^{* * *} \\
(0.024)\end{array}$ \\
\hline High School Graduate & $\begin{array}{l}0.272^{\text {**** }} \\
(0.012)\end{array}$ & $\begin{array}{l}0.278^{* * * *} \\
(0.011)\end{array}$ & $\begin{array}{l}0.387^{* * *} \\
(0.011)\end{array}$ & $\begin{array}{l}0.367^{* * * *} \\
(0.018)\end{array}$ & $\begin{array}{l}0.284^{* * *} \\
(0.012)\end{array}$ & $\begin{array}{l}0.288^{* * *} \\
(0.011)\end{array}$ & $\begin{array}{l}0.377^{* * * *} \\
(0.011)\end{array}$ & $\begin{array}{l}0.362^{* * *} \\
(0.016)\end{array}$ & $\begin{array}{l}0.135^{\text {*** }} \\
(0.011)\end{array}$ & $\begin{array}{l}0.159^{* * * *} \\
(0.009)\end{array}$ & $\begin{array}{l}0.280^{* * *} \\
(0.011)\end{array}$ & $\begin{array}{l}0.300^{* * *} \\
(0.016)\end{array}$ \\
\hline College & $\begin{array}{l}0.409^{* * *} \\
(0.017)\end{array}$ & $\begin{array}{l}0.496^{* * *} \\
(0.008)\end{array}$ & $\begin{array}{l}0.535^{* * *} \\
(0.011)\end{array}$ & $\begin{array}{l}0.485^{* * * *} \\
(0.024)\end{array}$ & $\begin{array}{l}0.430^{* * * *} \\
(0.020)\end{array}$ & $\begin{array}{l}0.493^{* * *} \\
(0.008)\end{array}$ & $\begin{array}{l}0.520^{* * *} \\
(0.010)\end{array}$ & $\begin{array}{l}0.466^{* * *} \\
(0.022)\end{array}$ & $\begin{array}{l}0.224^{* * *} \\
(0.016)\end{array}$ & $\begin{array}{l}0.280^{* * *} \\
(0.007)\end{array}$ & $\begin{array}{l}0.323^{* * *} \\
(0.009)\end{array}$ & $\begin{array}{l}0.318^{* * * *} \\
(0.021)\end{array}$ \\
\hline Female & $\begin{array}{l}-0.708^{* * *} \\
(0.015)\end{array}$ & $\begin{array}{l}-0.502^{\text {**** }} \\
(0.014)\end{array}$ & $\begin{array}{l}-0.407^{* * *} \\
(0.013)\end{array}$ & $\begin{array}{l}-0.264^{* * * *} \\
(0.012)\end{array}$ & $\begin{array}{l}-0.612^{* * *} \\
(0.012)\end{array}$ & $\begin{array}{l}-0.450^{* * * *} \\
(0.010)\end{array}$ & $\begin{array}{l}-0.370^{* * *} \\
(0.011)\end{array}$ & $\begin{array}{l}-0.215^{* * *} \\
(0.012)\end{array}$ & $\begin{array}{l}-0.588^{* * * *} \\
(0.011)\end{array}$ & $\begin{array}{l}-0.462^{* * *} \\
(0.008)\end{array}$ & $\begin{array}{l}-0.391^{* * *} \\
(0.011)\end{array}$ & $\begin{array}{l}-0.221^{* * *} \\
(0.012)\end{array}$ \\
\hline Wholesale Trade & & & & & $\begin{array}{l}0.407^{* * *} \\
(0.019)\end{array}$ & $\begin{array}{l}0.395^{* * *} \\
(0.016)\end{array}$ & $\begin{array}{l}0.365^{* * * *} \\
(0.015)\end{array}$ & $\begin{array}{l}0.352^{* * *} \\
(0.031)\end{array}$ & $\begin{array}{l}0.379^{* * * *} \\
(0.015)\end{array}$ & $\begin{array}{l}0.373^{* * *} \\
(0.015)\end{array}$ & $\begin{array}{l}0.347^{* * *} \\
(0.014)\end{array}$ & $\begin{array}{l}0.332^{* * * *} \\
(0.030)\end{array}$ \\
\hline Services & & & & & $\begin{array}{l}0.158^{* * *} \\
(0.021)\end{array}$ & $\begin{array}{l}0.213^{* * *} \\
(0.014)\end{array}$ & $\begin{array}{l}0.195^{* * *} \\
(0.013)\end{array}$ & $\begin{array}{l}0.202^{* * *} \\
(0.014)\end{array}$ & $\begin{array}{l}0.139^{* * *} \\
(0.018)\end{array}$ & $\begin{array}{l}0.161^{* * *} \\
(0.011)\end{array}$ & $\begin{array}{l}0.143^{* * *} \\
(0.013)\end{array}$ & $\begin{array}{l}0.151^{* * *} \\
(0.015)\end{array}$ \\
\hline Finance & & & & & $\begin{array}{l}0.344^{* * * *} \\
(0.032)\end{array}$ & $\begin{array}{l}0.396^{* * *} \\
(0.023)\end{array}$ & $\begin{array}{l}0.387^{* * *} \\
(0.017)\end{array}$ & $\begin{array}{l}0.372^{* * * *} \\
(0.022)\end{array}$ & $\begin{array}{l}0.276^{* * * *} \\
(0.028)\end{array}$ & $\begin{array}{l}0.282^{* * * *} \\
(0.023)\end{array}$ & $\begin{array}{l}0.262^{* * * *} \\
(0.018)\end{array}$ & $\begin{array}{l}0.263^{* * * *} \\
(0.020)\end{array}$ \\
\hline Utilities \& Transportation & & & & & $\begin{array}{l}0.364^{* * *} \\
(0.020)\end{array}$ & $\begin{array}{l}0.423^{* * *} \\
(0.009)\end{array}$ & $\begin{array}{l}0.360^{* * *} \\
(0.011)\end{array}$ & $\begin{array}{l}0.365^{* * *} \\
(0.027)\end{array}$ & $\begin{array}{l}0.401^{* * *} \\
(0.018)\end{array}$ & $\begin{array}{l}0.422^{* * *} \\
(0.009)\end{array}$ & $\begin{array}{l}0.350^{* * *} \\
(0.013)\end{array}$ & $\begin{array}{l}0.326^{* * * *} \\
(0.024)\end{array}$ \\
\hline Manufacturing & & & & & $\begin{array}{l}0.460^{* * * *} \\
(0.017)\end{array}$ & $\begin{array}{l}0.433^{* * *} \\
(0.013)\end{array}$ & $\begin{array}{l}0.356^{* * * *} \\
(0.012)\end{array}$ & $\begin{array}{l}0.372^{* * *} \\
(0.017)\end{array}$ & $\begin{array}{l}0.449^{* * *} \\
(0.016)\end{array}$ & $\begin{array}{l}0.414^{* * *} \\
(0.013)\end{array}$ & $\begin{array}{l}0.344^{* * *} \\
(0.013)\end{array}$ & $\begin{array}{l}0.341^{* * *} \\
(0.020)\end{array}$ \\
\hline Construction & & & & & $\begin{array}{l}0.260^{* * * *} \\
(0.025)\end{array}$ & $\begin{array}{l}0.232^{* * *} \\
(0.014)\end{array}$ & $\begin{array}{l}0.242^{* * * *} \\
(0.016)\end{array}$ & $\begin{array}{l}0.337^{* * *} \\
(0.021)\end{array}$ & $\begin{array}{l}0.205^{* * *} \\
(0.022)\end{array}$ & $\begin{array}{l}0.167^{* * *} \\
(0.012)\end{array}$ & $\begin{array}{l}0.189^{* * *} \\
(0.020)\end{array}$ & $\begin{array}{l}0.235^{* * *} \\
(0.020)\end{array}$ \\
\hline Mining & & & & & $\begin{array}{l}0.685^{* * * *} \\
(0.052)\end{array}$ & $\begin{array}{l}0.605^{* * *} \\
(0.021)\end{array}$ & $\begin{array}{l}0.571^{* * * *} \\
(0.034)\end{array}$ & $\begin{array}{l}0.835^{* * *} \\
(0.055)\end{array}$ & $\begin{array}{l}0.634^{\text {*** }} \\
(0.052)\end{array}$ & $\begin{array}{l}0.556^{* * *} \\
(0.020)\end{array}$ & $\begin{array}{l}0.533^{* * *} \\
(0.034)\end{array}$ & $\begin{array}{l}0.753^{\text {**** }} \\
(0.053)\end{array}$ \\
\hline Technical Sales \& Administrative Support & & & & & & & & & $\begin{array}{l}-0.368^{* * * *} \\
(0.012)\end{array}$ & $\begin{array}{l}-0.331^{* * *} \\
(0.007)\end{array}$ & $\begin{array}{l}-0.279^{* * *} \\
(0.008)\end{array}$ & $\begin{array}{l}-0.231^{* * *} \\
(0.016)\end{array}$ \\
\hline Service & & & & & & & & & $\begin{array}{l}-0.774^{* * *} \\
(0.016)\end{array}$ & $\begin{array}{l}-0.734^{* * *} \\
(0.009)\end{array}$ & $\begin{array}{l}-0.632^{* * *} \\
(0.009)\end{array}$ & $\begin{array}{l}-0.506^{* * *} \\
(0.019)\end{array}$ \\
\hline Farming, Forestry \& Fishing & & & & & & & & & $\begin{array}{l}-1.149^{* * *} \\
(0.053)\end{array}$ & $\begin{array}{l}-0.901^{* * *} \\
(0.036)\end{array}$ & $\begin{array}{l}-0.623^{* * *} \\
(0.035)\end{array}$ & $\begin{array}{l}-0.771^{* * *} \\
(0.094)\end{array}$ \\
\hline Precision Production, Craft \& Repair & & & & & & & & & $\begin{array}{l}-0.368^{* * * *} \\
(0.015)\end{array}$ & $\begin{array}{l}-0.360^{* * * *} \\
(0.009)\end{array}$ & $\begin{array}{l}-0.327^{* * *} \\
(0.018)\end{array}$ & $\begin{array}{l}-0.160^{* * * *} \\
(0.023)\end{array}$ \\
\hline Operators, Fabricators \& Labourers & & & & & & & & & $\begin{array}{l}-0.620^{* * *} \\
(0.015)\end{array}$ & $\begin{array}{l}-0.613^{* * *} \\
(0.012)\end{array}$ & $\begin{array}{l}-0.561^{* * *} \\
(0.014)\end{array}$ & $\begin{array}{l}-0.416^{* * *} \\
(0.026)\end{array}$ \\
\hline Constant & $\begin{array}{l}7.839^{* * * *} \\
(0.199)\end{array}$ & $\begin{array}{l}8.787^{* * *} \\
(0.033)\end{array}$ & $\begin{array}{l}7.051^{* * *} \\
(0.076)\end{array}$ & $\begin{array}{l}3.380^{* * * *} \\
(0.524)\end{array}$ & $\begin{array}{l}8.319^{\text {**** }} \\
(0.202)\end{array}$ & $\begin{array}{l}8.631^{* * * *} \\
(0.034)\end{array}$ & $\begin{array}{l}6.912^{* * * *} \\
(0.070)\end{array}$ & $\begin{array}{l}3.745^{* * *} \\
(0.534)\end{array}$ & $\begin{array}{l}8.771^{* * *} \\
(0.195)\end{array}$ & $\begin{array}{l}9.021^{* * *} \\
(0.034)\end{array}$ & $\begin{array}{l}7.572^{* * * *} \\
(0.063)\end{array}$ & $\begin{array}{l}4.155^{\text {*** }} \\
(0.510)\end{array}$ \\
\hline Observations & 51908 & 160577 & 94243 & 23213 & 51908 & 160577 & 94243 & 23213 & 51908 & 160577 & 94243 & 23213 \\
\hline$R^{2}$ & 0.263 & 0.235 & 0.245 & 0.191 & 0.296 & 0.265 & 0.269 & 0.224 & 0.360 & 0.330 & 0.321 & 0.263 \\
\hline
\end{tabular}

Note: This table presents estimates of Equation (3) but pooling across industries and disaggregating instead by industry, including covariates but not fixed effects. The dependent variable is $\log$ wages. The specification estimated is: $\log w_{j, t}^{g}=X_{j, t}^{\prime} \beta^{g}+\varepsilon_{j, t}^{g} \cdot \varepsilon_{j, t}^{g}$ are clustered by state. The data from the CPS and BEA are merged at the state geographic level and onedigit industry code as described in Appendix A. The generation variables are all dummy variables defined on the basis of date of birth, as per Table 1 . The omitted category is the Silent Generation, retail industry and the Managerial \& Speciality occupation. Standard errors are in parenthesis. ${ }^{* *}$ Significant at the $1 \%$ level. ${ }^{* *}$ Significant at the $5 \%$ level. ${ }^{*}$ Significant at the $10 \%$ level. 
Table B.11: Labour share regressions by generation

\begin{tabular}{|c|c|c|c|c|c|c|c|c|c|c|c|c|}
\hline & $\begin{array}{c}(1) \\
\text { Silent } \\
\beta / \mathrm{SE}\end{array}$ & $\begin{array}{c}(2) \\
\text { Boomer's } \\
\beta / \mathrm{SE}\end{array}$ & $\begin{array}{c}(3) \\
\text { Gen. } \boldsymbol{X} \\
\beta / \mathrm{SE}\end{array}$ & $\begin{array}{c}(4) \\
\text { Millenials } \\
\beta / \mathrm{SE}\end{array}$ & $\begin{array}{c}(5) \\
\text { Silent } \\
\beta / \mathrm{SE}\end{array}$ & $\begin{array}{c}(6) \\
\text { Boomer's } \\
\beta / \mathrm{SE}\end{array}$ & $\begin{array}{c}(7) \\
\text { Gen. } \boldsymbol{X} \\
\beta / \mathrm{SE}\end{array}$ & $\begin{array}{c}(8) \\
\text { Millenials } \\
\beta / \mathrm{SE}\end{array}$ & $\begin{array}{c}(9) \\
\text { Silent } \\
\beta / \mathrm{SE}\end{array}$ & $\begin{array}{c}(10) \\
\text { Boomer's } \\
\beta / \mathrm{SE}\end{array}$ & $\begin{array}{c}(11) \\
\text { Gen. } \boldsymbol{X} \\
\beta / \mathrm{SE}\end{array}$ & $\begin{array}{c}(12) \\
\text { Millenials } \\
\beta / \mathrm{SE}\end{array}$ \\
\hline Age & $\begin{array}{l}0.003^{* * *} \\
(0.000)\end{array}$ & $\begin{array}{l}-0.001^{* * *} \\
(0.000)\end{array}$ & $\begin{array}{l}0.004^{* * *} \\
(0.001)\end{array}$ & $\begin{array}{c}0.001 \\
(0.006)\end{array}$ & $\begin{array}{l}-0.001^{* *} \\
(0.000)\end{array}$ & $\begin{array}{l}-0.003^{* * * *} \\
(0.000)\end{array}$ & $\begin{array}{l}0.001^{* *} \\
(0.001)\end{array}$ & $\begin{array}{l}-0.007^{* * *} \\
(0.003)\end{array}$ & $\begin{array}{l}-0.001^{* *} \\
(0.000)\end{array}$ & $\begin{array}{l}-0.003^{* * *} \\
(0.000)\end{array}$ & $\begin{array}{l}0.001^{* *} \\
(0.001)\end{array}$ & $\begin{array}{l}-0.007 \text { *** } \\
(0.003)\end{array}$ \\
\hline Age Sq & $\begin{array}{l}-0.000^{* * * *} \\
(0.000)\end{array}$ & $\begin{array}{l}0.000^{* * * *} \\
(0.000)\end{array}$ & $\begin{array}{l}-0.000^{* * * *} \\
(0.000)\end{array}$ & $\begin{array}{c}0.000 \\
(0.000)\end{array}$ & $\begin{array}{l}0.000 \\
(0.000)\end{array}$ & $\begin{array}{l}0.000^{* * *} \\
(0.000)\end{array}$ & $\begin{array}{l}-0.000^{* *} \\
(0.000)\end{array}$ & $\begin{array}{l}0.000^{* * *} \\
(0.000)\end{array}$ & $\begin{array}{c}0.000 \\
(0.000)\end{array}$ & $\begin{array}{l}0.000^{* * *} \\
(0.000)\end{array}$ & $\begin{array}{l}-0.000^{* *} \\
(0.000)\end{array}$ & $\begin{array}{l}0.000^{* * * *} \\
(0.000)\end{array}$ \\
\hline African American & $\begin{array}{l}0.006^{* * *} \\
(0.001)\end{array}$ & $\begin{array}{l}0.005^{* * *} \\
(0.001)\end{array}$ & $\begin{array}{l}0.0099^{* * *} \\
(0.001)\end{array}$ & $\begin{array}{l}0.008^{* * * *} \\
(0.002)\end{array}$ & $\begin{array}{l}-0.003^{* *} \\
(0.001)\end{array}$ & $\begin{array}{l}-0.002^{* * *} \\
(0.001)\end{array}$ & $\begin{array}{l}-0.002^{* *} \\
(0.001)\end{array}$ & $\begin{array}{l}-0.002^{*} \\
(0.001)\end{array}$ & $\begin{array}{l}-0.002 \\
(0.001)\end{array}$ & $\begin{array}{l}-0.001^{*} \\
(0.001)\end{array}$ & $\begin{array}{l}-0.002 * * \\
(0.001)\end{array}$ & $\begin{array}{l}-0.002^{*} \\
(0.001)\end{array}$ \\
\hline Hispanic & $\begin{array}{l}-0.002 \\
(0.001)\end{array}$ & $\begin{array}{l}-0.004^{* * * *} \\
(0.001)\end{array}$ & $\begin{array}{c}-0.001 \\
(0.001)\end{array}$ & $\begin{array}{c}-0.000 \\
(0.002)\end{array}$ & $\begin{array}{l}-0.007^{* * *} \\
(0.001)\end{array}$ & $\begin{array}{l}-0.006^{* * *} \\
(0.001)\end{array}$ & $\begin{array}{l}-0.001 \\
(0.001)\end{array}$ & $\begin{array}{l}-0.002^{*} \\
(0.001)\end{array}$ & $\begin{array}{l}-0.006^{* * * *} \\
(0.001)\end{array}$ & $\begin{array}{l}-0.006^{* * *} \\
(0.001)\end{array}$ & $\begin{array}{l}-0.001 \\
(0.001)\end{array}$ & $\begin{array}{l}-0.002^{*} \\
(0.001)\end{array}$ \\
\hline High School Graduate & $\begin{array}{l}-0.006^{* * *} \\
(0.001)\end{array}$ & $\begin{array}{l}-0.003^{* * * *} \\
(0.001)\end{array}$ & $\begin{array}{l}0.016^{* * *} \\
(0.001)\end{array}$ & $\begin{array}{l}0.021^{* * *} \\
(0.002)\end{array}$ & $\begin{array}{l}-0.014^{* * *} \\
(0.001)\end{array}$ & $\begin{array}{l}-0.016^{* * *} \\
(0.000)\end{array}$ & $\begin{array}{l}-0.002 \\
(0.001)\end{array}$ & $\begin{array}{l}-0.001 \\
(0.001)\end{array}$ & $\begin{array}{l}-0.015^{* * *} \\
(0.001)\end{array}$ & $\begin{array}{l}-0.017^{* * * *} \\
(0.000)\end{array}$ & $\begin{array}{l}-0.002 \\
(0.001)\end{array}$ & $\begin{array}{l}-0.000 \\
(0.001)\end{array}$ \\
\hline College & $\begin{array}{l}0.015^{* * *} \\
(0.002)\end{array}$ & $\begin{array}{l}0.017^{* * *} \\
(0.001)\end{array}$ & $\begin{array}{l}0.024^{* * *} \\
(0.001)\end{array}$ & $\begin{array}{l}0.029^{* * * *} \\
(0.002)\end{array}$ & $\begin{array}{c}0.002 \\
(0.002)\end{array}$ & $\begin{array}{l}0.001^{*} \\
(0.001)\end{array}$ & $\begin{array}{l}0.004^{* * *} \\
(0.001)\end{array}$ & $\begin{array}{l}0.004^{* * *} \\
(0.001)\end{array}$ & $\begin{array}{l}0.000 \\
(0.002)\end{array}$ & $\begin{array}{c}0.000 \\
(0.001)\end{array}$ & $\begin{array}{l}0.003^{* * *} \\
(0.001)\end{array}$ & $\begin{array}{l}0.004^{* * *} * \\
(0.001)\end{array}$ \\
\hline Female & $\begin{array}{l}0.007^{* * *} \\
(0.001)\end{array}$ & $\begin{array}{l}0.014^{* * *} \\
(0.001)\end{array}$ & $\begin{array}{l}0.016^{* * *} \\
(0.001)\end{array}$ & $\begin{array}{l}0.015^{* * *} \\
(0.002)\end{array}$ & $\begin{array}{l}-0.002^{* *} \\
(0.001)\end{array}$ & $\begin{array}{c}-0.001 \\
(0.000)\end{array}$ & $\begin{array}{l}-0.000 \\
(0.001)\end{array}$ & $\begin{array}{l}-0.001 \\
(0.001)\end{array}$ & $\begin{array}{l}-0.003^{* * *} \\
(0.001)\end{array}$ & $\begin{array}{l}{ }^{*}-0.001^{* *} \\
(0.001)\end{array}$ & $\begin{array}{l}-0.001 \\
(0.001)\end{array}$ & $\begin{array}{c}-0.001 \\
(0.001)\end{array}$ \\
\hline Wholesale Trade & & & & & $\begin{array}{l}-0.020^{\text {*** }} \\
(0.000)\end{array}$ & $\begin{array}{l}-0.016^{* * * *} \\
(0.000)\end{array}$ & $\begin{array}{l}-0.014^{* * *} \\
(0.000)\end{array}$ & $\begin{array}{l}-0.013^{* * *} \\
(0.000)\end{array}$ & $\begin{array}{l}-0.021^{* * *} \\
(0.000)\end{array}$ & $\begin{array}{l}*-0.016^{* * * *} \\
(0.000)\end{array}$ & $\begin{array}{l}-0.013^{* * *} \\
(0.000)\end{array}$ & $\begin{array}{l}-0.012^{* * *} \\
(0.000)\end{array}$ \\
\hline Services & & & & & $\begin{array}{l}0.090^{* * * *} \\
(0.000)\end{array}$ & $\begin{array}{l}0.095^{* * *} \\
(0.000)\end{array}$ & $\begin{array}{l}0.097^{* * *} \\
(0.000)\end{array}$ & $\begin{array}{l}0.100^{* * *} \\
(0.000)\end{array}$ & $\begin{array}{l}0.091^{* * * *} \\
(0.000)\end{array}$ & $\begin{array}{l}0.095^{* * *} \\
(0.000)\end{array}$ & $\begin{array}{l}0.097^{* * *} \\
(0.000)\end{array}$ & $\begin{array}{l}0.100^{* * * *} \\
(0.000)\end{array}$ \\
\hline Finance & & & & & $\begin{array}{l}0.219^{* * * *} \\
(0.007)\end{array}$ & $\begin{array}{l}0.293^{* * *} \\
(0.003)\end{array}$ & $\begin{array}{l}0.335^{* * * *} \\
(0.003)\end{array}$ & $\begin{array}{l}0.367^{* * *} \\
(0.005)\end{array}$ & $\begin{array}{l}0.218^{* * * *} \\
(0.007)\end{array}$ & $\begin{array}{l}0.292^{* * * *} \\
(0.003)\end{array}$ & $\begin{array}{l}0.336^{* * * *} \\
(0.003)\end{array}$ & $\begin{array}{l}0.368^{* * *} \\
(0.005)\end{array}$ \\
\hline Utilities \& Transportation & & & & & $\begin{array}{l}0.106^{* * *} \\
(0.008)\end{array}$ & $\begin{array}{l}0.166^{* * *} \\
(0.003)\end{array}$ & $\begin{array}{l}0.216^{* * *} \\
(0.004)\end{array}$ & $\begin{array}{l}0.208^{* * *} \\
(0.003)\end{array}$ & $\begin{array}{l}0.106^{* * *} \\
(0.008)\end{array}$ & $\begin{array}{l}0.167^{* * *} \\
(0.003)\end{array}$ & $\begin{array}{l}0.217^{* * * *} \\
(0.005)\end{array}$ & $\begin{array}{l}0.208^{* * *} \\
(0.003)\end{array}$ \\
\hline Manufacturing & & & & & $\begin{array}{l}0.075^{* * * *} \\
(0.000)\end{array}$ & $\begin{array}{l}0.046^{* * *} \\
(0.000)\end{array}$ & $\begin{array}{l}0.014^{* * * *} \\
(0.000)\end{array}$ & $\begin{array}{l}0.007^{* * *} \\
(0.000)\end{array}$ & $\begin{array}{l}0.076^{* * *} \\
(0.001)\end{array}$ & $\begin{array}{l}0.046^{* * *} \\
(0.000)\end{array}$ & $\begin{array}{l}0.015^{* * *} \\
(0.001)\end{array}$ & $\begin{array}{l}0.008^{* * *} \\
(0.001)\end{array}$ \\
\hline Construction & & & & & $\begin{array}{l}0.040^{* * * *} \\
(0.001)\end{array}$ & $\begin{array}{l}0.037^{* * *} \\
(0.000)\end{array}$ & $\begin{array}{l}0.033^{* * *} \\
(0.000)\end{array}$ & $\begin{array}{l}0.031^{* * *} \\
(0.000)\end{array}$ & $\begin{array}{l}0.042^{* * *} \\
(0.001)\end{array}$ & $\begin{array}{l}0.037^{* * *} \\
(0.001)\end{array}$ & $\begin{array}{l}0.035^{* * *} \\
(0.001)\end{array}$ & $\begin{array}{l}0.032^{* * *} \\
(0.001)\end{array}$ \\
\hline Mining & & & & & $\begin{array}{l}0.050^{* * * *} \\
(0.003)\end{array}$ & $\begin{array}{l}0.041^{* * * *} \\
(0.002)\end{array}$ & $\begin{array}{l}0.020^{* * *} \\
(0.002)\end{array}$ & $\begin{array}{l}0.013^{* * *} \\
(0.001)\end{array}$ & $\begin{array}{l}0.051^{* * *} \\
(0.003)\end{array}$ & $\begin{array}{l}0.041^{* * *} \\
(0.002)\end{array}$ & $\begin{array}{l}0.021^{* * *} \\
(0.002)\end{array}$ & $\begin{array}{l}0.014^{* * * *} \\
(0.001)\end{array}$ \\
\hline Technical Sales \& Administrative Support & & & & & & & & & $\begin{array}{c}0.000 \\
(0.001)\end{array}$ & $\begin{array}{l}-0.000 \\
(0.001)\end{array}$ & $\begin{array}{c}0.001 \\
(0.001)\end{array}$ & $\begin{array}{l}-0.000 \\
(0.001)\end{array}$ \\
\hline Service & & & & & & & & & $\begin{array}{l}-0.006^{* * * *} \\
(0.001)\end{array}$ & $\begin{array}{l}-0.003^{* * * *} \\
(0.001)\end{array}$ & $\begin{array}{c}0.002 \\
(0.001)\end{array}$ & $\begin{array}{l}0.002^{* *} \\
(0.001)\end{array}$ \\
\hline Farming, Forestry \& Fishing & & & & & & & & & $\begin{array}{l}-0.016^{* * *} \\
(0.006)\end{array}$ & $\begin{array}{l}\text { * }-0.012^{* * *} \\
(0.003)\end{array}$ & $\begin{array}{l}-0.006 \\
(0.003)\end{array}$ & $\begin{array}{l}-0.008^{*} \\
(0.004)\end{array}$ \\
\hline Precision Production, Craft \& Repair & & & & & & & & & $\begin{array}{l}-0.005^{* * *} \\
(0.001)\end{array}$ & $\begin{array}{l}-0.003^{* * *} \\
(0.001)\end{array}$ & $\begin{array}{l}-0.003^{* *} \\
(0.001)\end{array}$ & $\begin{array}{l}-0.001 \\
(0.001)\end{array}$ \\
\hline Operators, Fabricators \& Labourers & & & & & & & & & $\begin{array}{l}-0.004^{* * *} \\
(0.001)\end{array}$ & $\begin{array}{l}-0.003^{* * *} \\
(0.001)\end{array}$ & $\begin{array}{l}-0.002 \\
(0.001)\end{array}$ & $\begin{array}{c}0.000 \\
(0.001)\end{array}$ \\
\hline Constant & $\begin{array}{c}0.009 \\
(0.011)\end{array}$ & $\begin{array}{l}0.117^{* * * *} \\
(0.004)\end{array}$ & $\begin{array}{c}0.007 \\
(0.012)\end{array}$ & $\begin{array}{c}0.007 \\
(0.081)\end{array}$ & $\begin{array}{l}0.075^{* * * *} \\
(0.009)\end{array}$ & $\begin{array}{l}0.115^{* * * *} \\
(0.002)\end{array}$ & $\begin{array}{c}0.007 \\
(0.009)\end{array}$ & $\begin{array}{l}0.099^{* * *} \\
(0.035)\end{array}$ & $\begin{array}{l}0.078^{* * * *} \\
(0.009)\end{array}$ & $\begin{array}{l}0.116^{* * *} \\
(0.003)\end{array}$ & $\begin{array}{c}0.007 \\
(0.010)\end{array}$ & $\begin{array}{l}0.098^{* * * *} \\
(0.035)\end{array}$ \\
\hline Observations & 51888 & 160485 & 94141 & 23212 & 51888 & 160485 & 94141 & 23212 & 51888 & 160485 & 94141 & 23212 \\
\hline$R^{2}$ & 0.007 & 0.010 & 0.017 & 0.042 & 0.292 & 0.363 & 0.443 & 0.802 & 0.292 & 0.363 & 0.443 & 0.802 \\
\hline
\end{tabular}

Note: This table presents estimates of Equation (3) but pooling across industries and disaggregating instead by industry, including covariates but not fixed effects. The dependent variable is the labour share of value added. The specification estimated is: $\log w_{j, t}^{g}=X_{j, t}^{\prime} \beta^{g}+\varepsilon_{j, t}^{g}$. The data from the CPS and BEA are merged at the state geographic level and one-digit industry code as described in Appendix A. The generation variables are all dummy variables defined on the basis of date of birth, as per Table 1. The omitted category is the Silent Generation, retail industry and the Managerial \& Speciality occupation. Standard errors are in parenthesis. ${ }^{* *}$ Significant at the $1 \%$ level. ${ }^{* *}$ Significant at the $5 \%$ level. ${ }^{*}$ Significant at the $10 \%$ level. 
Table B.12: Labour share regressions by generation with fixed effects

\begin{tabular}{|c|c|c|c|c|c|c|c|c|c|c|c|c|}
\hline & $\begin{array}{c}(1) \\
\text { Silent } \\
\beta / \mathrm{SE}\end{array}$ & $\begin{array}{c}(2) \\
\text { Boomer's } \\
\beta / \mathrm{SE}\end{array}$ & $\begin{array}{c}(3) \\
\text { Gen. } \boldsymbol{X} \\
\beta / \mathrm{SE}\end{array}$ & $\begin{array}{c}(4) \\
\text { Millenials } \\
\beta / \mathrm{SE}\end{array}$ & $\begin{array}{c}(5) \\
\text { Silent } \\
\beta / \mathrm{SE} \\
\end{array}$ & $\begin{array}{c}(6) \\
\text { Boomer's } \\
\beta / \mathrm{SE}\end{array}$ & $\begin{array}{c}(7) \\
\text { Gen. } \boldsymbol{X} \\
\beta / \mathrm{SE} \\
\end{array}$ & $\begin{array}{c}(8) \\
\text { Millenials } \\
\beta / \mathrm{SE}\end{array}$ & $\begin{array}{c}(9) \\
\text { Silent } \\
\beta / \mathrm{SE}\end{array}$ & $\begin{array}{c}(10) \\
\text { Boomer's } \\
\beta / \mathrm{SE}\end{array}$ & $\begin{array}{c}(11) \\
\text { Gen. } \boldsymbol{X} \\
\beta / \mathrm{SE}\end{array}$ & $\begin{array}{c}(12) \\
\text { Millenials } \\
\beta / \mathrm{SE}\end{array}$ \\
\hline Age & $\begin{array}{l}0.003^{* * *} \\
(0.001)\end{array}$ & $\begin{array}{ll}* 0.001 * * \\
(0.001)\end{array}$ & $\begin{array}{l}0.004^{* *} \\
(0.001)\end{array}$ & $\begin{array}{c}0.002 \\
(0.005)\end{array}$ & $\begin{array}{l}-0.001^{*} \\
(0.000)\end{array}$ & $\begin{array}{l}-0.003^{* * * *} \\
(0.000)\end{array}$ & $\begin{array}{c}0.001 \\
(0.001)\end{array}$ & $\begin{array}{l}-0.007 * * \\
(0.003)\end{array}$ & $\begin{array}{l}-0.001 * \\
(0.000)\end{array}$ & $\begin{array}{l}-0.003^{* * *} \\
(0.000)\end{array}$ & $\begin{array}{c}0.001 \\
(0.001)\end{array}$ & $\begin{array}{l}-0.007^{* *} \\
(0.003)\end{array}$ \\
\hline Age Sq & $\begin{array}{l}-0.000^{* * *} \\
(0.000)\end{array}$ & $\begin{array}{l}0.000 * * * \\
(0.000)\end{array}$ & $\begin{array}{l}-0.000^{* *} \\
(0.000)\end{array}$ & $\begin{array}{c}0.000 \\
(0.000)\end{array}$ & $\begin{array}{c}0.000 \\
(0.000)\end{array}$ & $\begin{array}{l}0.000^{* * * *} \\
(0.000)\end{array}$ & $\begin{array}{c}-0.000 \\
(0.000)\end{array}$ & $\begin{array}{l}0.000^{* * *} \\
(0.000)\end{array}$ & $\begin{array}{c}0.000 \\
(0.000)\end{array}$ & $\begin{array}{l}0.000^{* * *} \\
(0.000)\end{array}$ & $\begin{array}{l}-0.000 \\
(0.000)\end{array}$ & $\begin{array}{l}0.000^{* * *} \\
(0.000)\end{array}$ \\
\hline African American & $\begin{array}{l}0.009^{* * *} \\
(0.001)\end{array}$ & $\begin{array}{l}0.007^{* * *} \\
(0.002)\end{array}$ & $\begin{array}{l}0.010^{* * *} \\
(0.003)\end{array}$ & $\begin{array}{l}0.008^{* * * *} \\
(0.002)\end{array}$ & $\begin{array}{l}-0.001 \\
(0.001)\end{array}$ & $\begin{array}{c}0.001 \\
(0.001)\end{array}$ & $\begin{array}{c}0.000 \\
(0.002)\end{array}$ & $\begin{array}{l}-0.000 \\
(0.001)\end{array}$ & $\begin{array}{c}0.000 \\
(0.001)\end{array}$ & $\begin{array}{c}0.001 \\
(0.001)\end{array}$ & $\begin{array}{c}0.000 \\
(0.002)\end{array}$ & $\begin{array}{l}-0.000 \\
(0.001)\end{array}$ \\
\hline Hispanic & $\begin{array}{l}-0.001 \\
(0.001)\end{array}$ & $\begin{array}{l}-0.004^{*} \\
(0.003)\end{array}$ & $\begin{array}{l}-0.004^{* *} \\
(0.002)\end{array}$ & $\begin{array}{l}-0.003 \\
(0.002)\end{array}$ & $\begin{array}{l}-0.006^{* * *} \\
(0.001)\end{array}$ & $\begin{array}{l}-0.005^{* *} \\
(0.002)\end{array}$ & $\begin{array}{l}-0.000 \\
(0.001)\end{array}$ & $\begin{array}{l}-0.000 \\
(0.001)\end{array}$ & $\begin{array}{l}-0.005^{* * *} \\
(0.001)\end{array}$ & $\begin{array}{l}-0.004^{* *} \\
(0.002)\end{array}$ & $\begin{array}{c}0.000 \\
(0.001)\end{array}$ & $\begin{array}{l}-0.000 \\
(0.001)\end{array}$ \\
\hline High School Graduate & $\begin{array}{l}-0.006^{* * * *} \\
(0.001)\end{array}$ & $\begin{array}{l}-0.004^{* * *} \\
(0.001)\end{array}$ & $\begin{array}{l}0.016^{\text {**** }} \\
(0.002)\end{array}$ & $\begin{array}{l}0.021^{* * * *} \\
(0.003)\end{array}$ & $\begin{array}{l}-0.014^{* * *} \\
(0.002)\end{array}$ & $\begin{array}{l}-0.016^{* * * *} \\
(0.001)\end{array}$ & $\begin{array}{l}-0.002^{* *} \\
(0.001)\end{array}$ & $\begin{array}{l}-0.001 \\
(0.001)\end{array}$ & $\begin{array}{l}-0.015^{* * *} \\
(0.002)\end{array}$ & $\begin{array}{l}{ }^{*}-0.017^{* * * *} \\
(0.001)\end{array}$ & $\begin{array}{l}-0.002^{*} \\
(0.001)\end{array}$ & $\begin{array}{l}-0.001 \\
(0.001)\end{array}$ \\
\hline College & $\begin{array}{l}0.015^{\text {*** }} \\
(0.002)\end{array}$ & $\begin{array}{l}0.016^{* * *} \\
(0.001)\end{array}$ & $\begin{array}{l}0.022^{\text {**** }} \\
(0.002)\end{array}$ & $\begin{array}{l}0.025^{* * *} \\
(0.002)\end{array}$ & $\begin{array}{c}0.001 \\
(0.002)\end{array}$ & $\begin{array}{c}0.000 \\
(0.001)\end{array}$ & $\begin{array}{c}0.002^{* *} \\
(0.001)\end{array}$ & $\begin{array}{l}0.002^{* *} \\
(0.001)\end{array}$ & $\begin{array}{l}-0.000 \\
(0.002)\end{array}$ & $\begin{array}{l}-0.001 \\
(0.001)\end{array}$ & $\begin{array}{c}0.002^{*} \\
(0.001)\end{array}$ & $\begin{array}{l}0.002^{* *} \\
(0.001)\end{array}$ \\
\hline Female & $\begin{array}{l}0.007^{* * *} \\
(0.001)\end{array}$ & $\begin{array}{l}0.014^{* * *} \\
(0.001)\end{array}$ & $\begin{array}{l}0.016^{* * *} \\
(0.002)\end{array}$ & $\begin{array}{l}0.015^{* * *} \\
(0.002)\end{array}$ & $\begin{array}{l}-0.002^{* * *} \\
(0.001)\end{array}$ & $* \begin{array}{c}-0.001 \\
(0.000)\end{array}$ & $\begin{array}{l}-0.000 \\
(0.001)\end{array}$ & $\begin{array}{l}-0.001 \\
(0.001)\end{array}$ & $\begin{array}{l}-0.003^{* * * *} \\
(0.001)\end{array}$ & $\begin{array}{l}-0.001^{* * * *} \\
(0.000)\end{array}$ & $\begin{array}{l}-0.001 \\
(0.001)\end{array}$ & $\begin{array}{l}-0.001 \\
(0.001)\end{array}$ \\
\hline Wholesale Trade & & & & & $\begin{array}{l}-0.020^{* * *} \\
(0.001)\end{array}$ & $\begin{array}{l}-0.015^{* * *} \\
(0.001)\end{array}$ & $\begin{array}{l}-0.014^{* * *} \\
(0.000)\end{array}$ & $\begin{array}{l}-0.014^{* * * *} \\
(0.001)\end{array}$ & $\begin{array}{l}-0.021^{* * * *} \\
(0.001)\end{array}$ & $\begin{array}{l}{ }^{*}-0.015^{* * *} \\
(0.001)\end{array}$ & $\begin{array}{l}-0.014^{* * *} \\
(0.000)\end{array}$ & $\begin{array}{l}-0.013^{* * *} \\
(0.001)\end{array}$ \\
\hline Services & & & & & $\begin{array}{l}0.090^{* * *} \\
(0.001)\end{array}$ & $\begin{array}{l}0.095^{* * *} \\
(0.001)\end{array}$ & $\begin{array}{l}0.097^{* * *} \\
(0.001)\end{array}$ & $\begin{array}{l}0.100^{* * *} \\
(0.002)\end{array}$ & $\begin{array}{l}0.091^{* * * *} \\
(0.001)\end{array}$ & $\begin{array}{l}0.095^{* * *} \\
(0.001)\end{array}$ & $\begin{array}{l}0.097^{* * *} \\
(0.002)\end{array}$ & $\begin{array}{l}0.100^{* * *} \\
(0.002)\end{array}$ \\
\hline Finance & & & & & $\begin{array}{l}0.219^{* * * *} \\
(0.016)\end{array}$ & $\begin{array}{l}0.293^{* * *} \\
(0.024)\end{array}$ & $\begin{array}{l}0.335^{* * * *} \\
(0.027)\end{array}$ & $\begin{array}{l}0.367^{* * *} \\
(0.031)\end{array}$ & $\begin{array}{l}0.218^{* * *} \\
(0.016)\end{array}$ & $\begin{array}{l}0.293^{* * * *} \\
(0.024)\end{array}$ & $\begin{array}{l}0.336^{* * *} \\
(0.027)\end{array}$ & $\begin{array}{l}0.368^{* * * *} \\
(0.031)\end{array}$ \\
\hline Utilities \& Transportation & & & & & $\begin{array}{l}0.106^{* * *} \\
(0.017)\end{array}$ & $\begin{array}{l}0.167^{* * *} \\
(0.016)\end{array}$ & $\begin{array}{l}0.216^{* * * *} \\
(0.023)\end{array}$ & $\begin{array}{l}0.209^{* * *} \\
(0.021)\end{array}$ & $\begin{array}{l}0.107^{\text {**** }} \\
(0.017)\end{array}$ & $\begin{array}{l}0.167^{* * *} \\
(0.016)\end{array}$ & $\begin{array}{l}0.217^{* * *} \\
(0.024)\end{array}$ & $\begin{array}{l}0.209^{* * *} \\
(0.021)\end{array}$ \\
\hline Manufacturing & & & & & $\begin{array}{l}0.074^{* * * *} \\
(0.002)\end{array}$ & $\begin{array}{l}0.045^{* * * *} \\
(0.002)\end{array}$ & $\begin{array}{l}0.013^{* * * *} \\
(0.002)\end{array}$ & $\begin{array}{l}0.007^{* * * *} \\
(0.002)\end{array}$ & $\begin{array}{l}0.075^{* * * *} \\
(0.003)\end{array}$ & $\begin{array}{l}0.045^{* * *} \\
(0.002)\end{array}$ & $\begin{array}{l}0.015^{* * * *} \\
(0.002)\end{array}$ & $\begin{array}{l}0.007^{* * * *} \\
(0.002)\end{array}$ \\
\hline Construction & & & & & $\begin{array}{l}0.041^{* * * *} \\
(0.002)\end{array}$ & $\begin{array}{l}0.037^{* * *} \\
(0.001)\end{array}$ & $\begin{array}{l}0.034^{* * *} \\
(0.001)\end{array}$ & $\begin{array}{l}0.032^{* * * *} \\
(0.001)\end{array}$ & $\begin{array}{l}0.042^{\text {*** }} \\
(0.002)\end{array}$ & $\begin{array}{c}0.038^{* * *} \\
(0.001)\end{array}$ & $\begin{array}{l}0.036^{* * *} \\
(0.002)\end{array}$ & $\begin{array}{l}0.033^{* * *} \\
(0.001)\end{array}$ \\
\hline Mining & & & & & $\begin{array}{l}0.056^{* * *} \\
(0.010)\end{array}$ & $\begin{array}{l}0.048^{* * *} \\
(0.009)\end{array}$ & $\begin{array}{l}0.028^{* * *} \\
(0.005)\end{array}$ & $\begin{array}{l}0.021^{* * *} \\
(0.003)\end{array}$ & $\begin{array}{l}0.057^{* * *} \\
(0.010)\end{array}$ & $\begin{array}{l}0.049^{* * *} \\
(0.009)\end{array}$ & $\begin{array}{l}0.030^{* * * *} \\
(0.006)\end{array}$ & $\begin{array}{l}0.022^{* * *} \\
(0.003)\end{array}$ \\
\hline Technical Sales \& Administrative Support & & & & & & & & & $\begin{array}{l}0.000 \\
(0.002)\end{array}$ & $\begin{array}{l}-0.000 \\
(0.001)\end{array}$ & $\begin{array}{c}0.001 \\
(0.003)\end{array}$ & $\begin{array}{c}0.000 \\
(0.001)\end{array}$ \\
\hline Service & & & & & & & & & $\begin{array}{l}-0.006^{* * * *} \\
(0.001)\end{array}$ & $\begin{array}{l}{ }^{*}-0.003^{* * *} \\
(0.001)\end{array}$ & $\begin{array}{c}0.002 \\
(0.002)\end{array}$ & $\begin{array}{l}0.001 \\
(0.001)\end{array}$ \\
\hline Farming, Forestry \& Fishing & & & & & & & & & $\begin{array}{l}-0.014^{* * * *} \\
(0.005)\end{array}$ & $\begin{array}{l}-0.013^{* * * *} \\
(0.003)\end{array}$ & $\begin{array}{l}-0.005 \\
(0.003)\end{array}$ & $\begin{array}{l}-0.006 \\
(0.004)\end{array}$ \\
\hline Precision Production, Craft \& Repair & & & & & & & & & $\begin{array}{l}-0.005^{* * *} \\
(0.001)\end{array}$ & $\begin{array}{l}-0.003^{* * *} \\
(0.001)\end{array}$ & $\begin{array}{c}-0.002 \\
(0.001)\end{array}$ & $\begin{array}{l}-0.001 \\
(0.001)\end{array}$ \\
\hline Operators, Fabricators \& Labourers & & & & & & & & & $\begin{array}{l}-0.004^{* * * *} \\
(0.001)\end{array}$ & $\begin{array}{l}{ }^{*}-0.003^{* * *} \\
(0.001)\end{array}$ & $\begin{array}{l}-0.002 \\
(0.001)\end{array}$ & $\begin{array}{c}0.000 \\
(0.001)\end{array}$ \\
\hline Constant & $\begin{array}{c}0.011 \\
(0.013) \\
\end{array}$ & $\begin{array}{l}0.116^{* * * *} \\
(0.012)\end{array}$ & $\begin{array}{c}0.007 \\
(0.023) \\
\end{array}$ & $\begin{array}{l}-0.001 \\
(0.063) \\
\end{array}$ & $\begin{array}{l}0.075^{* * *} \\
(0.010)\end{array}$ & $\begin{array}{l}0.114^{* * *} \\
(0.007)\end{array}$ & $\begin{array}{c}0.006 \\
(0.015) \\
\end{array}$ & $\begin{array}{l}0.090^{* * * *} \\
(0.033)\end{array}$ & $\begin{array}{l}0.078^{\text {**** }} \\
(0.010)\end{array}$ & $\begin{array}{l}0.115^{* * *} \\
(0.008)\end{array}$ & $\begin{array}{c}0.006 \\
(0.015)\end{array}$ & $\begin{array}{l}0.089^{\text {**** }} \\
(0.033)\end{array}$ \\
\hline Observations & 51888 & 160485 & 94141 & 23212 & 51888 & 160485 & 941 & 23212 & 51888 & 160485 & 94141 & 23212 \\
\hline$R^{2}$ & 0.022 & 0.022 & 0.031 & 0.056 & 0.303 & 0.374 & 0.456 & 0.814 & 0.303 & 0.374 & 0.456 & 0.814 \\
\hline
\end{tabular}

Note: This table presents estimates of Equation (3) but pooling across industries and disaggregating instead by industry, including covariates and state fixed effects. The dependent variable is the labour share of value added. The specification estimated is: $\log w_{j, t}^{g}=X_{j+t}^{\prime} \beta^{g}+\delta_{s}+\varepsilon_{j, t}^{g} \cdot \varepsilon_{j, t}^{g}$ are clustered by state. The data from the CPS and BEA are merged at the state geographic level and one-digit industry code as described in Appendix A. The generation variables are all dummy variables defined on the basis of date of birth, as per Table 1 . The omitted category is the Silent Generation, retail industry and the Managerial \& Speciality occupation. Standard errors are in parenthesis. ${ }^{* *}$ Significant at the $1 \%$ level.** Significant at the $5 \%$ level. * Significant at the $10 \%$ level. 
Table B.13: Generational differences in wage and the labour share: Pooled estimates

\begin{tabular}{|c|c|c|c|c|c|c|c|c|}
\hline & $\begin{array}{c}(1) \\
\text { Wage } \\
\beta / \mathrm{SE}\end{array}$ & $\begin{array}{c}(2) \\
\text { Wage } \\
\beta / \mathrm{SE}\end{array}$ & $\begin{array}{c}(3) \\
\text { Wage } \\
\beta / \mathrm{SE}\end{array}$ & $\begin{array}{c}(4) \\
\text { Wage L } \\
\beta / \mathrm{SE}\end{array}$ & $\begin{array}{c}(5) \\
\text { Labour Share } \\
\beta / \mathrm{SE}\end{array}$ & $\begin{array}{c}(6) \\
\text { Labour Share } \\
\beta / \mathrm{SE}\end{array}$ & $\begin{array}{c}(7) \\
\text { Labour Share } \\
\beta / \mathrm{SE}\end{array}$ & $\begin{array}{c}(8) \\
\text { Labour Share } \\
\beta / \mathrm{SE}\end{array}$ \\
\hline Baby Boomers & $\begin{array}{c}0.080^{* *} \\
(0.005)\end{array}$ & $\begin{array}{c}*-0.019 * \\
(0.005)\end{array}$ & $\begin{array}{c}k^{* *}-0.016^{*} * \\
(0.005)\end{array}$ & $\begin{array}{l}* 0.025^{* * *} \\
(0.005)\end{array}$ & $\begin{array}{l}0.002^{* * *} \\
(0.001)\end{array}$ & $\begin{array}{l}0.003^{* * *} \\
(0.001)\end{array}$ & $\begin{array}{l}-0.006^{* * *} \\
(0.000)\end{array}$ & $\begin{array}{l}-0.006^{* * *} \\
(0.000)\end{array}$ \\
\hline Gen. X. & $\begin{array}{c}0.015^{* *} \\
(0.005)\end{array}$ & $\begin{array}{c}*-0.065 * \\
(0.006)\end{array}$ & $\begin{array}{c}* * 0.043 * \\
(0.006)\end{array}$ & $\begin{array}{l}* 0.033^{* * *} \\
(0.006)\end{array}$ & $\begin{array}{l}0.004^{* * *} \\
(0.001)\end{array}$ & $\begin{array}{l}0.007^{* * *} \\
(0.001)\end{array}$ & $\begin{array}{l}-0.008^{* * * *} \\
(0.001)\end{array}$ & $\begin{array}{l}-0.007^{* * *} \\
(0.001)\end{array}$ \\
\hline Millennials & $\begin{array}{l}-0.182^{* *} \\
(0.008)\end{array}$ & $\begin{array}{c}*-129 * \\
(0.009)\end{array}$ & $\begin{array}{c}k *-0.087^{*} \\
(0.009)\end{array}$ & $\begin{array}{c}* 0.011 \\
(0.008)\end{array}$ & $\begin{array}{l}0.002^{* *} \\
(0.001)\end{array}$ & $\begin{array}{l}0.007^{* * *} \\
(0.001)\end{array}$ & $\begin{array}{l}-0.009^{* * *} \\
(0.001)\end{array}$ & $\begin{array}{l}-0.008^{* * *} \\
(0.001)\end{array}$ \\
\hline Age & & $\begin{array}{l}0.082^{* *} \\
(0.001)\end{array}$ & $\begin{array}{c}* 0.077^{* *} \\
(0.001)\end{array}$ & $\begin{array}{l}* 0.073^{* * *} \\
(0.001)\end{array}$ & & $\begin{array}{l}0.001^{* * *} \\
(0.000)\end{array}$ & $\begin{array}{l}-0.000 \\
(0.000)\end{array}$ & $\begin{array}{l}-0.000 \\
(0.000)\end{array}$ \\
\hline Age Sq & & $\begin{array}{l}-0.001^{*} \\
(0.000)\end{array}$ & $\begin{array}{c}k *-0.001 * \\
(0.000)\end{array}$ & $\begin{array}{c}*-0.001^{* * * *} \\
(0.000)\end{array}$ & & $\begin{array}{l}-0.000^{* * *} \\
(0.000)\end{array}$ & $\begin{array}{l}-0.000 \\
(0.000)\end{array}$ & $\begin{array}{l}-0.000 \\
(0.000)\end{array}$ \\
\hline African American & & $\begin{array}{l}-0.198^{*} \\
(0.005)\end{array}$ & $\begin{array}{c}* * 0.200^{*} * \\
(0.005)\end{array}$ & $\begin{array}{l}*_{-}-0.117^{* * * *} \\
(0.005)\end{array}$ & & $\begin{array}{l}0.007^{* * *} \\
(0.001)\end{array}$ & $\begin{array}{l}-0.002^{\text {*** }} \\
(0.000)\end{array}$ & $\begin{array}{l}-0.001^{* * * *} \\
(0.000)\end{array}$ \\
\hline Hispanic & & $\begin{array}{l}-0.189^{*} \\
(0.004)\end{array}$ & $\begin{array}{c}* * 0.183^{*} \\
(0.004)\end{array}$ & $\begin{array}{l}*-0.121^{* * * *} \\
(0.004)\end{array}$ & & $\begin{array}{l}-0.005^{* * *} \\
(0.001)\end{array}$ & $\begin{array}{l}-0.006^{\text {*** }} \\
(0.000)\end{array}$ & $\begin{array}{l}-0.006^{* * *} \\
(0.000)\end{array}$ \\
\hline High School Graduate & & $\begin{array}{l}0.291^{* *} \\
(0.004)\end{array}$ & $\begin{array}{c}0.296 * * \\
(0.004)\end{array}$ & $\begin{array}{l}* 0.176^{* * *} \\
(0.004)\end{array}$ & & $\begin{array}{l}-0.001^{* *} \\
(0.000)\end{array}$ & $\begin{array}{l}-0.016^{* * * *} \\
(0.000)\end{array}$ & $\begin{array}{l}-0.017^{* * *} \\
(0.000)\end{array}$ \\
\hline College & & $\begin{array}{l}0.520^{* *} \\
(0.004)\end{array}$ & $\begin{array}{c}0.514^{* *} \\
(0.004)\end{array}$ & $\begin{array}{l}* 0.302^{* * * *} \\
(0.004)\end{array}$ & & $\begin{array}{l}0.021^{* * *} \\
(0.001)\end{array}$ & $\begin{array}{l}0.003^{* * *} \\
(0.001)\end{array}$ & $\begin{array}{l}0.002^{\text {*** }} \\
(0.001)\end{array}$ \\
\hline Female & & $\begin{array}{l}-0.489^{*} \\
(0.003)\end{array}$ & $\begin{array}{c}* *-0.437 * \\
(0.003)\end{array}$ & $\begin{array}{c}*-0.447^{* * *} \\
(0.003)\end{array}$ & & $\begin{array}{l}0.014^{* * *} \\
(0.000)\end{array}$ & $\begin{array}{l}-0.001 \\
(0.000)\end{array}$ & $\begin{array}{l}-0.001^{* * *} \\
(0.000)\end{array}$ \\
\hline Wholesale Trade & & & $\begin{array}{l}0.397^{* *} \\
(0.008)\end{array}$ & $\begin{array}{l}* 0.372^{* * *} \\
(0.007)\end{array}$ & & & $\begin{array}{l}-0.016^{\text {**** }} \\
(0.000)\end{array}$ & $\begin{array}{l}-0.016^{* * *} \\
(0.000)\end{array}$ \\
\hline Services & & & $\begin{array}{c}0.206^{* *} \\
(0.005)\end{array}$ & $\begin{array}{l}* 0.154^{* * *} \\
(0.005)\end{array}$ & & & $\begin{array}{l}0.096^{* * *} \\
(0.000)\end{array}$ & $\begin{array}{l}0.096^{* * *} \\
(0.000)\end{array}$ \\
\hline Finance & & & $\begin{array}{c}0.392^{* *} \\
(0.008)\end{array}$ & $\begin{array}{l}* 0.273^{* * *} \\
(0.008)\end{array}$ & & & $\begin{array}{l}0.308^{* * *} \\
(0.002)\end{array}$ & $\begin{array}{l}0.308^{* * *} \\
(0.002)\end{array}$ \\
\hline Utilities \& Transportation & & & $\begin{array}{c}0.392^{* *} \\
(0.007)\end{array}$ & $\begin{array}{l}* 0.390 * * * \\
(0.007)\end{array}$ & & & $\begin{array}{l}0.181^{* * *} \\
(0.002)\end{array}$ & $\begin{array}{l}0.182^{* * *} \\
(0.002)\end{array}$ \\
\hline Manufacturing & & & $\begin{array}{c}0.420^{* *} \\
(0.005)\end{array}$ & $\begin{array}{l}* 0.406^{* * *} \\
(0.005)\end{array}$ & & & $\begin{array}{l}0.044^{* * *} \\
(0.000)\end{array}$ & $\begin{array}{l}0.045^{* * *} \\
(0.000)\end{array}$ \\
\hline Construction & & & $\begin{array}{c}0.252^{* *} \\
(0.007)\end{array}$ & $\begin{array}{l}* 0.187^{* * *} \\
(0.007)\end{array}$ & & & $\begin{array}{l}0.036^{* * *} \\
(0.000)\end{array}$ & $\begin{array}{l}0.037^{* * * *} \\
(0.000)\end{array}$ \\
\hline Mining & & & $\begin{array}{l}0.600^{* *} \\
(0.015)\end{array}$ & $\begin{array}{l}* 0.552^{* * *} \\
(0.014)\end{array}$ & & & $\begin{array}{l}0.035^{* * *} \\
(0.001)\end{array}$ & $\begin{array}{l}0.036^{* * * *} \\
(0.001)\end{array}$ \\
\hline Technical Sales \& Administrative Support & & & & $\begin{array}{l}-0.322^{\text {*** }} \\
(0.004)\end{array}$ & & & & $\begin{array}{l}-0.000 \\
(0.001)\end{array}$ \\
\hline Service & & & & $\begin{array}{l}-0.700^{\text {*** }} \\
(0.006)\end{array}$ & & & & $\begin{array}{l}-0.003^{* * *} \\
(0.001)\end{array}$ \\
\hline Farming, Forestry \& Fishing & & & & $\begin{array}{l}-0.878^{* * *} \\
(0.024)\end{array}$ & & & & $\begin{array}{l}-0.014^{* * *} \\
(0.002)\end{array}$ \\
\hline Precision Production, Craft \& Repair & & & & $\begin{array}{l}-0.347^{* * *} \\
(0.005)\end{array}$ & & & & $\begin{array}{l}-0.004^{* * *} \\
(0.001)\end{array}$ \\
\hline Operators, Fabricators \& Labourers & & & & $\begin{array}{l}-0.606^{* * *} \\
(0.005)\end{array}$ & & & & $\begin{array}{l}-0.004^{* * *} \\
(0.001)\end{array}$ \\
\hline Constant & $\begin{array}{l}10.033^{\text {** }} \\
(0.004)\end{array}$ & $\begin{array}{c}* .306 * * \\
(0.025)\end{array}$ & $\begin{array}{c}* .117 * * \\
(0.024)\end{array}$ & $\begin{array}{c}* 8.631^{* * * *} \\
(0.024)\end{array}$ & $\begin{array}{l}0.101^{* * *} \\
(0.000)\end{array}$ & $\begin{array}{l}0.067^{* * *} \\
(0.003)\end{array}$ & $\begin{array}{l}0.058^{* * *} \\
(0.002)\end{array}$ & $\begin{array}{l}0.060^{* * * *} \\
(0.002)\end{array}$ \\
\hline $\begin{array}{l}\text { Observations } \\
R^{2}\end{array}$ & $\begin{array}{c}329941 \\
0.006\end{array}$ & $\begin{array}{c}329941 \\
0.232\end{array}$ & $\begin{array}{c}329941 \\
0.260\end{array}$ & $\begin{array}{c}329941 \\
0.321\end{array}$ & $\begin{array}{c}329726 \\
0.000\end{array}$ & $\begin{array}{c}329726 \\
0.012\end{array}$ & $\begin{array}{l}329726 \\
0.395\end{array}$ & $\begin{array}{l}329726 \\
0.395\end{array}$ \\
\hline
\end{tabular}

Notes: This table presents estimates of Equation (3) but pooling across industries, including covariates but not fixed effects. The specification estimated is: $c_{j, t}^{i}=\gamma_{g}^{i}+X_{j, t}^{\prime} \beta^{i}+\varepsilon_{j, t}^{i}$. Where $c_{j, t}^{i}$, the dependent variable, is the log wage in Columns (1) to (3) and the labour share of value added in Columns (4) to (6). The data from the CPS and BEA are merged at the state geographic level and one-digit industry code as described in Appendix A. The generation variables are all dummy variables defined on the basis of date of birth, as per Table 1. The omitted category is the Silent Generation, Retail Industry and the Managerial \& Speciality occupation. Standard errors are in parenthesis. ${ }^{* * *}$ Significant at the $1 \%$ level. $^{* *}$ Significant at the $5 \%$ level. ${ }^{*}$ Significant at the $10 \%$ level. 
Table B.14: Wage and labour share regressions: Pooled estimates with state fixed effects

\begin{tabular}{|c|c|c|c|c|c|c|c|c|}
\hline & $\begin{array}{c}(1) \\
\text { Wage } \\
\beta / \text { SE }\end{array}$ & $\begin{array}{c}(2) \\
\text { Wage } \\
\beta / \mathrm{SE}\end{array}$ & $\begin{array}{c}(3) \\
\text { Wage } \\
\beta / \mathrm{SE}\end{array}$ & $\begin{array}{c}(4) \\
\text { Wage I } \\
\beta / \mathrm{SE}\end{array}$ & $\begin{array}{c}(5) \\
\text { Labour Share } \\
\beta / \mathrm{SE}\end{array}$ & $\begin{array}{c}(6) \\
\text { Labour Share } \\
\beta / \mathrm{SE}\end{array}$ & $\begin{array}{c}(7) \\
\text { Labour Share } \\
\beta / \mathrm{SE}\end{array}$ & $\begin{array}{c}(8) \\
\text { Labour Share } \\
\beta / \mathrm{SE}\end{array}$ \\
\hline Baby Boomers & $\begin{array}{c}0.081^{* *} \\
(0.009)\end{array}$ & $\begin{array}{r}*-0.013 \\
(0.008)\end{array}$ & $\begin{array}{l}-0.009 \\
(0.007)\end{array}$ & $\begin{array}{l}0.030^{* * *} \\
(0.007)\end{array}$ & $\begin{array}{c}0.003^{* *} \\
(0.001)\end{array}$ & $\begin{array}{l}0.004^{* * *} \\
(0.001)\end{array}$ & $\begin{array}{l}-0.006^{* * *} \\
(0.001)\end{array}$ & $\begin{array}{l}-0.005^{* * *} \\
(0.001)\end{array}$ \\
\hline Gen. X. & $\begin{array}{c}0.015 \\
(0.014)\end{array}$ & $\begin{array}{l}-0.054^{* *} \\
(0.012)\end{array}$ & $\begin{array}{r}* *_{-}-0.031 * \\
(0.011)\end{array}$ & $\begin{array}{c}* * 0.042^{* * *} \\
(0.010)\end{array}$ & $\begin{array}{l}0.005^{* *} \\
(0.002)\end{array}$ & $\begin{array}{l}0.008^{* * * *} \\
(0.003)\end{array}$ & $\begin{array}{l}-0.007^{* * *} \\
(0.002)\end{array}$ & $\begin{array}{l}-0.007^{* * *} \\
(0.002)\end{array}$ \\
\hline Millennials & $\begin{array}{l}-0.180^{* *} \\
(0.017)\end{array}$ & $\begin{array}{c}*-0.114^{* *} \\
(0.018)\end{array}$ & $\begin{array}{r}* *_{-}-0.071^{*} \\
(0.016)\end{array}$ & $\begin{array}{r}* * 0.024 \\
(0.015)\end{array}$ & $\begin{array}{c}0.003 \\
(0.002)\end{array}$ & $\begin{array}{l}0.008^{* *} \\
(0.003)\end{array}$ & $\begin{array}{l}-0.008^{* *} \\
(0.003)\end{array}$ & $\begin{array}{l}-0.007^{* *} \\
(0.003)\end{array}$ \\
\hline Age & & $\begin{array}{c}0.082^{* *} \\
(0.001)\end{array}$ & $\begin{array}{c}* * 0.077^{* *} \\
(0.001)\end{array}$ & $\begin{array}{c}* * 0.073^{* * *} \\
(0.001)\end{array}$ & & $\begin{array}{l}0.001^{* * *} \\
(0.000)\end{array}$ & $\begin{array}{l}-0.000 \\
(0.000)\end{array}$ & $\begin{array}{l}-0.000 \\
(0.000)\end{array}$ \\
\hline Age Sq & & $\begin{array}{l}-0.001^{* *} \\
(0.000)\end{array}$ & $\begin{array}{c}* *_{-} 0.001^{*} \\
(0.000)\end{array}$ & $\begin{array}{c}*_{-}-0.001^{* * *} \\
(0.000)\end{array}$ & & $\begin{array}{l}-0.000^{* *} \\
(0.000)\end{array}$ & $\begin{array}{l}-0.000 \\
(0.000)\end{array}$ & $\begin{array}{l}-0.000 \\
(0.000)\end{array}$ \\
\hline African American & & $\begin{array}{l}-0.205^{* *} \\
(0.011)\end{array}$ & $\begin{array}{r}* *_{-}-0.206^{*} \\
(0.012)\end{array}$ & $\begin{array}{c}* *_{-}-0.121^{* * *} \\
(0.009)\end{array}$ & & $\begin{array}{l}0.008^{* * *} \\
(0.002)\end{array}$ & $\begin{array}{c}0.000 \\
(0.001)\end{array}$ & $\begin{array}{c}0.001 \\
(0.001)\end{array}$ \\
\hline Hispanic & & $\begin{array}{l}-0.226^{* *} \\
(0.011)\end{array}$ & $\begin{array}{r}* *_{-}-0.224^{*} \\
(0.011)\end{array}$ & $\begin{array}{c}* *-0.150^{* * * *} \\
(0.012)\end{array}$ & & $\begin{array}{l}-0.006^{* * *} \\
(0.002)\end{array}$ & $\begin{array}{l}-0.005^{\text {*** }} \\
(0.001)\end{array}$ & $\begin{array}{l}-0.004^{* * *} \\
(0.001)\end{array}$ \\
\hline High School Graduate & & $\begin{array}{c}0.286^{* *} \\
(0.010)\end{array}$ & $\begin{array}{c}* * 0.291 * * \\
(0.010)\end{array}$ & $\begin{array}{c}* * 173^{* * *} \\
(0.008)\end{array}$ & & $\begin{array}{l}-0.001 \\
(0.001)\end{array}$ & $\begin{array}{l}-0.017^{* * *} \\
(0.001)\end{array}$ & $\begin{array}{l}-0.018^{* * *} \\
(0.001)\end{array}$ \\
\hline College & & $\begin{array}{l}0.506^{* *} \\
(0.008)\end{array}$ & $\begin{array}{c}k * 499^{* *} \\
(0.008)\end{array}$ & $\begin{array}{c}\text { ** } 0.293^{* * *} \\
(0.006)\end{array}$ & & $\begin{array}{l}0.019^{* * * *} \\
(0.002)\end{array}$ & $\begin{array}{l}0.002^{* *} \\
(0.001)\end{array}$ & $\begin{array}{c}0.001 \\
(0.001)\end{array}$ \\
\hline Female & & $\begin{array}{l}-0.489^{* *} \\
(0.013)\end{array}$ & $\begin{array}{r}* *_{-}-0.435^{*} \\
(0.009)\end{array}$ & $\begin{array}{c}* *-0.444^{* * *} \\
(0.008)\end{array}$ & & $\begin{array}{l}0.014^{* * *} \\
(0.001)\end{array}$ & $\begin{array}{l}-0.001 \\
(0.000)\end{array}$ & $\begin{array}{l}-0.001 \text { *** } \\
(0.000)\end{array}$ \\
\hline Wholesale Trade & & & $\begin{array}{c}0.395^{* *} \\
(0.012)\end{array}$ & $\begin{array}{c}\text { ** } 0.370^{* * * *} \\
(0.011)\end{array}$ & & & $\begin{array}{l}-0.016^{\text {*** }} \\
(0.000)\end{array}$ & $\begin{array}{l}-0.016^{* * *} \\
(0.000)\end{array}$ \\
\hline Services & & & $\begin{array}{l}0.201^{* *} \\
(0.012)\end{array}$ & $\begin{array}{c}* * 149^{* * *} \\
(0.010)\end{array}$ & & & $\begin{array}{l}0.096^{* * *} \\
(0.001)\end{array}$ & $\begin{array}{l}0.096^{* * *} \\
(0.001)\end{array}$ \\
\hline Finance & & & $\begin{array}{c}0.387^{* *} \\
(0.017)\end{array}$ & $\begin{array}{c}* * 270^{* * *} \\
(0.017)\end{array}$ & & & $\begin{array}{l}0.308^{* * *} \\
(0.025)\end{array}$ & $\begin{array}{l}0.308^{* * *} \\
(0.025)\end{array}$ \\
\hline Utilities \& Transportation & & & $\begin{array}{c}0.390^{* *} \\
(0.007)\end{array}$ & $\begin{array}{c}* * 0.387^{* * *} \\
(0.007)\end{array}$ & & & $\begin{array}{l}0.181^{* * *} \\
(0.018)\end{array}$ & $\begin{array}{l}0.182^{\text {*** }} \\
(0.018)\end{array}$ \\
\hline Manufacturing & & & $\begin{array}{c}0.424^{* *} \\
(0.013)\end{array}$ & $\begin{array}{c}\text { ** } 0.406^{* * * *} \\
(0.012)\end{array}$ & & & $\begin{array}{l}0.043^{* * *} \\
(0.002)\end{array}$ & $\begin{array}{l}0.044^{* * *} \\
(0.002)\end{array}$ \\
\hline Construction & & & $\begin{array}{c}0.251^{* *} \\
(0.012)\end{array}$ & $\begin{array}{c}* * 184^{* * *} \\
(0.012)\end{array}$ & & & $\begin{array}{l}0.036^{\text {*** }} \\
(0.001)\end{array}$ & $\begin{array}{l}0.037^{\text {*** }} \\
(0.001)\end{array}$ \\
\hline Mining & & & $\begin{array}{c}0.624^{* *} \\
(0.020)\end{array}$ & $\begin{array}{c}* * .574^{* * *} \\
(0.018)\end{array}$ & & & $\begin{array}{l}0.043^{* * *} \\
(0.008)\end{array}$ & $\begin{array}{l}0.043^{\text {*** }} \\
(0.008)\end{array}$ \\
\hline Technical Sales \& Administrative Support & & & & $\begin{array}{l}-0.320^{\text {*** }} \\
(0.005)\end{array}$ & & & & $\begin{array}{c}0.000 \\
(0.001)\end{array}$ \\
\hline Service & & & & $\begin{array}{l}-0.697^{* * *} \\
(0.006)\end{array}$ & & & & $\begin{array}{l}-0.003^{* * *} \\
(0.001)\end{array}$ \\
\hline Farming, Forestry \& Fishing & & & & $\begin{array}{l}-0.862^{* * *} \\
(0.024)\end{array}$ & & & & $\begin{array}{l}-0.013^{* * *} \\
(0.002)\end{array}$ \\
\hline Precision Production, Craft \& Repair & & & & $\begin{array}{l}-0.339^{* * * *} \\
(0.008)\end{array}$ & & & & $\begin{array}{l}-0.003^{* * *} \\
(0.001)\end{array}$ \\
\hline Operators, Fabricators \& Labourers & & & & $\begin{array}{l}-0.595^{* * *} \\
(0.010)\end{array}$ & & & & $\begin{array}{l}-0.004^{* * *} \\
(0.001)\end{array}$ \\
\hline Constant & $\begin{array}{l}10.032^{* *} \\
(0.009)\end{array}$ & $\begin{array}{c}* * 8.302^{* *} \\
(0.025)\end{array}$ & $\begin{array}{c}8.114^{* *} \\
(0.028)\end{array}$ & $\begin{array}{c}* * 8.622^{* * *} \\
(0.024)\end{array}$ & $\begin{array}{l}0.101^{* * *} \\
(0.001)\end{array}$ & $\begin{array}{l}0.066^{* * * *} \\
(0.008)\end{array}$ & $\begin{array}{l}0.057^{* * *} \\
(0.005)\end{array}$ & $\begin{array}{l}0.059^{\text {*** }} \\
(0.005)\end{array}$ \\
\hline $\begin{array}{l}\text { Observations } \\
R^{2}\end{array}$ & $\begin{array}{c}329941 \\
0.015\end{array}$ & $\begin{array}{c}329941 \\
0.237\end{array}$ & $\begin{array}{c}329941 \\
0.266\end{array}$ & $\begin{array}{c}329941 \\
0.326\end{array}$ & $\begin{array}{c}329726 \\
0.013\end{array}$ & $\begin{array}{c}329726 \\
0.024\end{array}$ & $\begin{array}{c}329726 \\
0.406\end{array}$ & $\begin{array}{c}329726 \\
0.406\end{array}$ \\
\hline
\end{tabular}

Notes: This table presents estimates of Equation (3) but pooling across industries, including covariates and fixed effects. The specification estimated is: $c_{j, t}^{i}=\gamma_{g}^{i}+X_{j, t}^{\prime} \beta^{i}+\delta_{s}+\varepsilon_{j, t}^{i}$. Where $c_{j, t}^{i}$, the dependent variable, is the log wage in Columns (1) to (3) and the labour share of value added in Columns (4) to (6). The data from the CPS and BEA are merged at the state geographic level and one-digit industry code as described in Appendix A. The generation variables are all dummy variables defined on the basis of date of birth, as per Table 1. The omitted category is the Silent Generation, Retail Industry and the Managerial \& Speciality occupation. Standard errors are in parenthesis. ${ }^{* * *}$ Significant at the $1 \%$ level. ${ }^{* *}$ Significant at the $5 \%$ level. ${ }^{*}$ Significant at the $10 \%$ level. 


\section{B.2 Robustness checks}

As a robustness check, we are able to reproduce the results of the regressions for real wage using the full CPS sample, rather than the restricted sample which allows us to merge the data to the Economic Census. For brevity, we include only the key variables of interest.

Table B.15: Wage regressions: Pooled estimates

\begin{tabular}{|c|c|c|c|c|c|c|c|c|}
\hline & $\begin{array}{c}(1) \\
\text { Wage } \\
\beta / \mathrm{SE}\end{array}$ & $\begin{array}{c}(2) \\
\text { Wage } \\
\beta / \mathrm{SE}\end{array}$ & $\begin{array}{c}(3) \\
\text { Wage } \\
\beta / \mathrm{SE}\end{array}$ & $\begin{array}{c}(4) \\
\text { Wage } \\
\beta / \mathrm{SE}\end{array}$ & $\begin{array}{c}(5) \\
\text { Wage } \\
\beta / \mathrm{SE}\end{array}$ & $\begin{array}{c}(6) \\
\text { Wage } \\
\beta / \mathrm{SE}\end{array}$ & $\begin{array}{c}(7) \\
\text { Wage } \\
\beta / \mathrm{SE}\end{array}$ & $\begin{array}{c}(8) \\
\text { Wage } \\
\beta / \text { SE }\end{array}$ \\
\hline Baby Boomers & $\begin{array}{l}0.080^{* * *} \\
(0.005)\end{array}$ & $\begin{array}{l}* 0.019^{* *} \\
(0.005)\end{array}$ & $\begin{array}{c}k^{* *}-0.016^{* *} \\
(0.005)\end{array}$ & $\begin{array}{c}\text { ** } 0.025^{* *} \\
(0.005)\end{array}$ & $\begin{array}{l}* 0.081^{* *} \\
(0.009)\end{array}$ & $\begin{array}{r}* 0.013 \\
(0.008)\end{array}$ & $\begin{array}{l}-0.009 \\
(0.007)\end{array}$ & $\begin{array}{l}0.030^{* * *} \\
(0.007)\end{array}$ \\
\hline Gen. X. & $\begin{array}{l}0.015^{* * *} \\
(0.005)\end{array}$ & $\begin{array}{l}* 0.065^{* *} \\
(0.006)\end{array}$ & $\begin{array}{c}* * 0.043^{* *} \\
(0.006)\end{array}$ & $\begin{array}{c}\text { ** } 0.033^{* * *} \\
(0.006)\end{array}$ & $\begin{array}{l}0.015 \\
(0.014)\end{array}$ & $\begin{array}{l}-0.054^{* *} \\
(0.012)\end{array}$ & $\begin{array}{c}{ }^{* *}-0.031^{* *} \\
(0.011)\end{array}$ & $\begin{array}{c}* * 0.042^{* * *} \\
(0.010)\end{array}$ \\
\hline Millennials & $\begin{array}{l}-0.182^{* *} \\
(0.008)\end{array}$ & $\begin{array}{c}*-0.129^{* *} \\
(0.009)\end{array}$ & $\begin{array}{c}k^{*}-0.087^{* *} \\
(0.009)\end{array}$ & $\begin{array}{c}* * 0.011 \\
(0.008)\end{array}$ & $\begin{array}{l}-0.180^{*} \\
(0.017)\end{array}$ & $\begin{array}{c}k_{-}^{*} 0.114^{* *} \\
(0.018)\end{array}$ & $\begin{array}{c}*{ }^{*}-0.071^{* *} \\
(0.016)\end{array}$ & $\begin{array}{r}* * 0.024 \\
(0.015)\end{array}$ \\
\hline Age & & $\begin{array}{c}0.082^{* *} \\
(0.001)\end{array}$ & $\begin{array}{c}* 0.077^{* *} \\
(0.001)\end{array}$ & $\begin{array}{c}* 0.073^{* *} \\
(0.001)\end{array}$ & & $\begin{array}{c}0.082^{* *} \\
(0.001)\end{array}$ & $\begin{array}{c}\text { ** } 0.077^{* * *} \\
(0.001)\end{array}$ & $\begin{array}{c}* * 073^{* * *} \\
(0.001)\end{array}$ \\
\hline Age Sq & & $\begin{array}{l}-0.001^{* *} \\
(0.000)\end{array}$ & $\begin{array}{c}k^{*}-0.001^{* *} \\
(0.000)\end{array}$ & $\begin{array}{c}* *-0.001^{* *} \\
(0.000)\end{array}$ & & $\begin{array}{l}-0.001^{* *} \\
(0.000)\end{array}$ & $\begin{array}{l}{ }^{* *}-0.001^{* *} \\
(0.000)\end{array}$ & $\begin{array}{c}* * 0.001^{* * *} \\
(0.000)\end{array}$ \\
\hline African American & & $\begin{array}{l}-0.198^{* *} \\
(0.005)\end{array}$ & $\begin{array}{c}k^{* *}-0.200^{* *} \\
(0.005)\end{array}$ & $\begin{array}{c}*{ }^{* *}-0.117^{* *} \\
(0.005)\end{array}$ & & $\begin{array}{l}-0.205^{* *} \\
(0.011)\end{array}$ & $\begin{array}{c}*{ }^{*}-0.206^{* *} \\
(0.012)\end{array}$ & $\begin{array}{c}* *-0.121^{* * *} \\
(0.009)\end{array}$ \\
\hline Hispanic & & $\begin{array}{l}-0.189^{* *} \\
(0.004)\end{array}$ & $\begin{array}{c}k^{* *}-0.183^{* *} \\
(0.004)\end{array}$ & $\begin{array}{c}{\text { **- }-0.121^{* *}}^{*}(0.004)\end{array}$ & & $\begin{array}{l}-0.226^{* *} \\
(0.011)\end{array}$ & $\begin{array}{l}{ }^{* *}-0.224^{* *} \\
(0.011)\end{array}$ & $\begin{array}{c}* * 0.150^{* * *} \\
(0.012)\end{array}$ \\
\hline High School Graduate & & $\begin{array}{c}0.291^{* *} \\
(0.004)\end{array}$ & $\begin{array}{c}* 0.296^{* *} \\
(0.004)\end{array}$ & $\begin{array}{l}* *^{*} 0.176^{* *} \\
(0.004)\end{array}$ & & $\begin{array}{c}0.286^{* *} \\
(0.010)\end{array}$ & $\begin{array}{l}*^{*} 0.291^{* * *} \\
(0.010)\end{array}$ & $\begin{array}{c}k^{* *} 0.173^{* * *} \\
(0.008)\end{array}$ \\
\hline College & & $\begin{array}{c}0.520^{* *} \\
(0.004)\end{array}$ & $\begin{array}{r}* 0.514^{* *} \\
(0.004)\end{array}$ & $\begin{array}{l}0.302^{* *} \\
(0.004)\end{array}$ & & $\begin{array}{c}0.506^{* *} \\
(0.008)\end{array}$ & $\begin{array}{l}* * 499^{* * *} \\
(0.008)\end{array}$ & $\begin{array}{c}* * 0.293^{* * *} \\
(0.006)\end{array}$ \\
\hline Female & & $\begin{array}{l}-0.489^{* *} \\
(0.003)\end{array}$ & $\begin{array}{c}*_{-}^{*}-0.437^{* *} \\
(0.003)\end{array}$ & $\begin{array}{c}*{ }^{*}-0.447^{* *} \\
(0.003)\end{array}$ & & $\begin{array}{l}-0.489^{* *} \\
(0.013)\end{array}$ & $\begin{array}{c}*{ }^{*}-0.435^{* *} \\
(0.009)\end{array}$ & $\begin{array}{c}* *-0.444^{* * *} \\
(0.008)\end{array}$ \\
\hline Wholesale Trade & & & $\begin{array}{c}0.397^{* *} \\
(0.008)\end{array}$ & $\begin{array}{c}* * 372^{* *} \\
(0.007)\end{array}$ & & & $\begin{array}{l}0.395^{* * *} \\
(0.012)\end{array}$ & $\begin{array}{c}* * 370^{* * *} \\
(0.011)\end{array}$ \\
\hline Services & & & $\begin{array}{l}0.206^{* *} \\
(0.005)\end{array}$ & $\begin{array}{l}*^{*} 0.154^{* *} \\
(0.005)\end{array}$ & & & $\begin{array}{l}0.201^{* *} \\
(0.012)\end{array}$ & $\begin{array}{c}* * 149^{* * *} \\
(0.010)\end{array}$ \\
\hline Finance & & & $\begin{array}{c}0.392^{* *} \\
(0.008)\end{array}$ & $\begin{array}{l}* * 273^{* *} \\
(0.008)\end{array}$ & & & $\begin{array}{l}0.387^{* *-} \\
(0.017)\end{array}$ & $\begin{aligned} * * & 0.270^{* * *} \\
& (0.017)\end{aligned}$ \\
\hline Utilities \& Transportation & & & $\begin{array}{c}0.392^{* *} \\
(0.007)\end{array}$ & $\begin{array}{c}* 0.390^{* * *} \\
(0.007)\end{array}$ & & & $\begin{array}{l}0.390^{* *} \\
(0.007)\end{array}$ & $\begin{array}{c}* * 387^{* * *} \\
(0.007)\end{array}$ \\
\hline Manufacturing & & & $\begin{array}{c}0.420^{* *} \\
(0.005)\end{array}$ & $\begin{array}{c}* 0.406^{* * *} \\
(0.005)\end{array}$ & & & $\begin{array}{l}0.424^{* * *} \\
(0.013)\end{array}$ & $\begin{array}{c}* * 0.406^{* * *} \\
(0.012)\end{array}$ \\
\hline Construction & & & $\begin{array}{c}0.252^{* *} \\
(0.007)\end{array}$ & $\begin{array}{l}0.187^{* *} \\
(0.007)\end{array}$ & & & $\begin{array}{l}0.251^{* *} \\
(0.012)\end{array}$ & 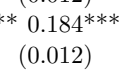 \\
\hline Mining & & & $\begin{array}{c}0.600^{* *} \\
(0.015)\end{array}$ & $\begin{array}{l}*^{*} 0.552^{* * *} \\
(0.014)\end{array}$ & & & $\begin{array}{l}0.624^{* * *} \\
(0.020)\end{array}$ & $\begin{array}{c}\text { k* } 0.574^{* * *} \\
(0.018)\end{array}$ \\
\hline Technical Sales \& Administrative Support & & & & $\begin{array}{l}-0.322^{* *} \\
(0.004)\end{array}$ & & & & $\begin{array}{l}-0.320^{* * *} \\
(0.005)\end{array}$ \\
\hline Service & & & & $\begin{array}{l}-0.700^{* *} \\
(0.006)\end{array}$ & & & & $\begin{array}{l}-0.697^{* *} \\
(0.006)\end{array}$ \\
\hline Farming, Forestry \& Fishing & & & & $\begin{array}{l}-0.878^{* *} \\
(0.024)\end{array}$ & & & & $\begin{array}{l}-0.862^{* * *} \\
(0.024)\end{array}$ \\
\hline Precision Production, Craft \& Repair & & & & $\begin{array}{l}-0.347^{* *} \\
(0.005)\end{array}$ & & & & $\begin{array}{l}-0.339^{* * *} \\
(0.008)\end{array}$ \\
\hline Operators, Fabricators \& Labourers & & & & $\begin{array}{l}-0.606^{* *} \\
(0.005)\end{array}$ & & & & $\begin{array}{l}-0.595^{* * *} \\
(0.010)\end{array}$ \\
\hline Constant & $\begin{array}{l}10.033^{* *} \\
(0.004)\end{array}$ & $\begin{array}{c}* * 8.306^{* *} \\
(0.025)\end{array}$ & $\begin{array}{c}\text { ** } 8.117^{* *} \\
(0.024)\end{array}$ & $\begin{array}{c}* 8.631^{* *} \\
(0.024)\end{array}$ & $\begin{array}{c}* 10.032^{*} \\
(0.009)\end{array}$ & $\begin{array}{c}* * 8.302^{* *} \\
(0.025)\end{array}$ & $\begin{array}{c}k^{*} 8.114^{* * *} \\
(0.028)\end{array}$ & $\begin{array}{c}\text { ** } 8.622^{* * *} \\
(0.024)\end{array}$ \\
\hline Observations & 329941 & 329941 & 329941 & 329941 & 329941 & 329941 & 329941 & 329941 \\
\hline$R^{2}$ & 0.006 & 0.232 & 0.260 & 0.321 & 0.015 & 0.237 & 0.266 & 0.326 \\
\hline State FE & No & No & No & No & Yes & Yes & Yes & Yes \\
\hline
\end{tabular}


Table B.16: Determinants of real wages by generation

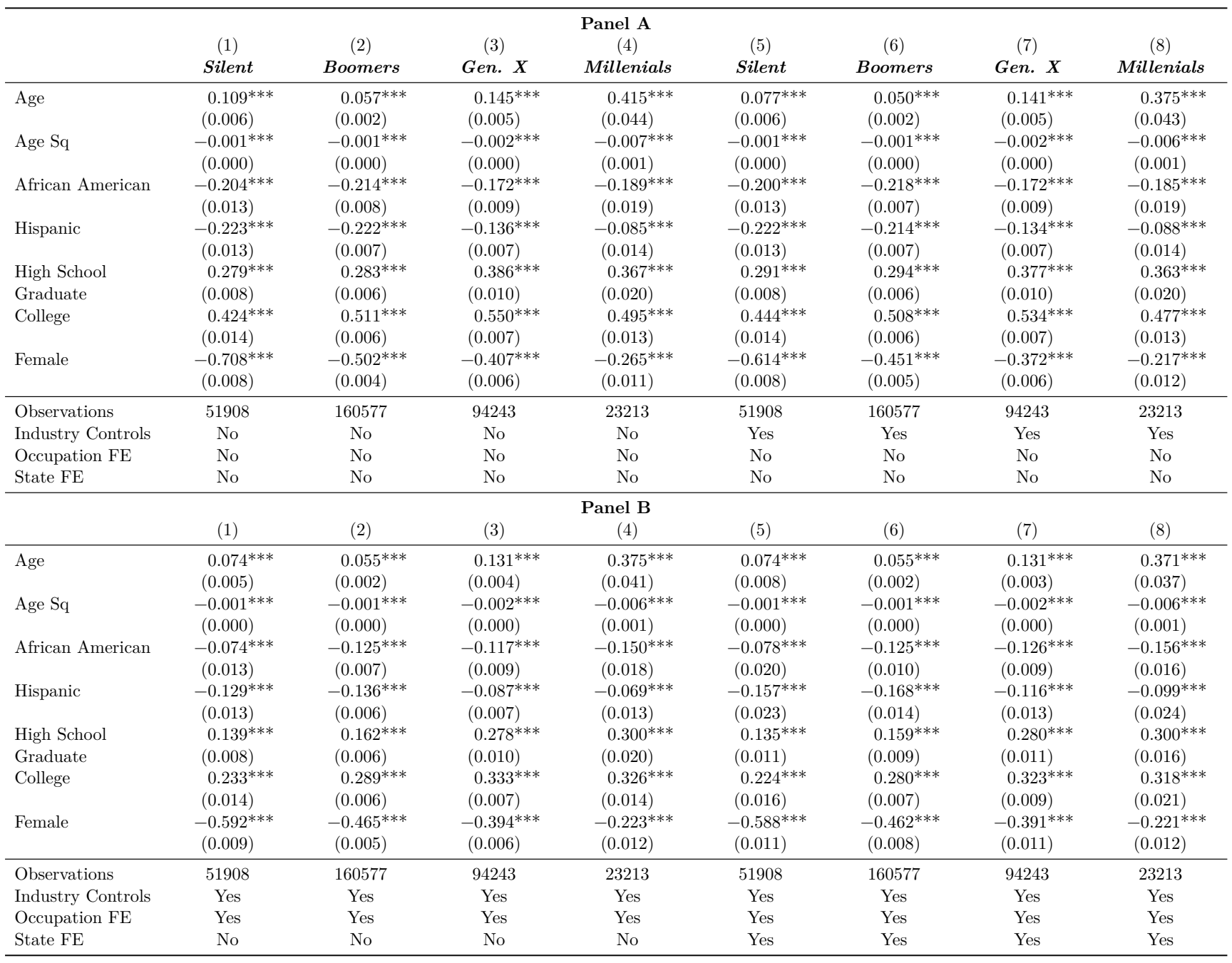

Note: Each panel and column is a regression where the dependent variable is Real Wage as seen in Equation (3) but pooling across industries and disaggregating instead by generation. The data is the full unmerged CPS including indvidual aged 23-55 who are not working in Government or self employed have income above the minimum income threshold. Panel A is the regression without fixed effects, Columns (1)-(4) do not include any additional controls, whilst Columns (5)-(8) include indusrty controls. Panel B, Columns (1) to (4) include industry controls and additional occupation controls. Whilst Columns (5) to (8) include the full control with state fixed effects. Generation is defined on the basis of date of birth, as per Table 1. Standard errors are in parenthesis. ${ }^{* * *}$ Significant at the $1 \%$ level. ${ }^{* *}$ Significant at the $5 \%$ level. ${ }^{*}$ Significant at the $10 \%$ level. 
Table B.17: Generational differences in real wages by industry

\begin{tabular}{|c|c|c|c|c|c|c|c|c|}
\hline & Retail & Wholesale & $\begin{array}{c}\text { Panel A: } \\
(3) \\
\text { Services }\end{array}$ & $\begin{array}{c}\text { ncondition } \\
\text { (4) } \\
\text { Finance }\end{array}$ & $\begin{array}{c}\text { I estimates } \\
(5) \\
\text { Utilities }\end{array}$ & $\begin{array}{c}(6) \\
\text { Manufacturing }\end{array}$ & $\begin{array}{c}(7) \\
\text { Construction }\end{array}$ & $\stackrel{(8)}{\text { Mining }}$ \\
\hline Baby Boomers & $\begin{array}{l}0.112^{* * *} \\
(0.013)\end{array}$ & $\begin{array}{c}0.010 \\
(0.020)\end{array}$ & $\begin{array}{l}0.186^{* * *} \\
(0.009)\end{array}$ & $\begin{array}{l}0.187^{* * *} \\
(0.031)\end{array}$ & $\begin{array}{l}0.101^{* * *} \\
(0.023)\end{array}$ & $\begin{array}{c}-0.019^{* *} \\
(0.008)\end{array}$ & $\begin{array}{c}-0.064^{* * *} \\
(0.017)\end{array}$ & $\begin{array}{c}-0.065 \\
(0.054)\end{array}$ \\
\hline Gen. X. & $\begin{array}{l}0.059^{* * *} \\
(0.013)\end{array}$ & $\begin{array}{c}-0.058^{* * *} \\
(0.022)\end{array}$ & $\begin{array}{l}0.205^{* * *} \\
(0.010)\end{array}$ & $\begin{array}{l}0.135^{* * *} \\
(0.032)\end{array}$ & $\begin{array}{c}-0.078^{* * *} \\
(0.024)\end{array}$ & $\begin{array}{c}-0.091^{* * *} \\
(0.010)\end{array}$ & $\begin{array}{c}-0.121^{* * *} \\
(0.018)\end{array}$ & $\begin{array}{c}-0.160^{* * *} \\
(0.059)\end{array}$ \\
\hline Millennials & $\begin{array}{c}-0.111^{* * * *} \\
(0.016)\end{array}$ & $\begin{array}{c}-0.279^{* * *} \\
(0.038)\end{array}$ & $\begin{array}{l}0.048^{* * *} \\
(0.013)\end{array}$ & $\begin{array}{c}-0.023 \\
(0.037)\end{array}$ & $\begin{array}{c}-0.301^{* * *} \\
(0.031)\end{array}$ & $\begin{array}{c}-0.259^{* * * *} \\
(0.018)\end{array}$ & $\begin{array}{c}-0.268^{* * *} \\
(0.024)\end{array}$ & $\begin{array}{r}-0.090 \\
(0.082)\end{array}$ \\
\hline Observations & 57739 & 14158 & 120231 & 13257 & 20872 & 73359 & 27138 & 3187 \\
\hline Fixed Effects & No & No & No & No & No & No & No & No \\
\hline Covariates & No & No & No & No & No & No & No & No \\
\hline Occupation FE & No & No & No & No & No & No & No & No \\
\hline \multicolumn{9}{|c|}{ Panel B: Including covariates } \\
\hline Baby Boomers & $\begin{array}{c}-0.019 \\
(0.013)\end{array}$ & $\begin{array}{c}-0.079^{* * *} \\
(0.019)\end{array}$ & $\begin{array}{l}0.067^{* * * *} \\
(0.009)\end{array}$ & $\begin{array}{l}0.091^{* * *} \\
(0.034)\end{array}$ & $\begin{array}{c}0.006 \\
(0.024)\end{array}$ & $\begin{array}{c}-0.084^{* * *} \\
(0.008)\end{array}$ & $\begin{array}{c}-0.129^{* * *} \\
(0.018)\end{array}$ & $\begin{array}{r}-0.082^{*} \\
(0.049)\end{array}$ \\
\hline Gen. X. & $\begin{array}{c}-0.048^{* * *} \\
(0.016)\end{array}$ & $\begin{array}{c}-0.113^{* * *} \\
(0.024)\end{array}$ & $\begin{array}{l}0.070^{* * *} \\
(0.011)\end{array}$ & $\begin{array}{l}0.179^{* * *} \\
(0.040)\end{array}$ & $\begin{array}{c}-0.043 \\
(0.028)\end{array}$ & $\begin{array}{c}-0.181^{* * *} \\
(0.011)\end{array}$ & $\begin{array}{c}-0.160^{* * *} \\
(0.022)\end{array}$ & $\begin{array}{r}-0.126^{*} \\
(0.065)\end{array}$ \\
\hline Millennials & $\begin{array}{c}-0.111^{* * * *} \\
(0.020)\end{array}$ & $\begin{array}{c}-0.192^{* * *} \\
(0.040)\end{array}$ & $\begin{array}{l}0.033^{* *} \\
(0.015)\end{array}$ & $\begin{array}{l}0.161^{* * *} \\
(0.047)\end{array}$ & $\begin{array}{c}-0.102^{* * *} \\
(0.037)\end{array}$ & $\begin{array}{l}-0.265^{* * *} \\
(0.019)\end{array}$ & $\begin{array}{c}-0.204^{* * * *} \\
(0.029)\end{array}$ & $\begin{array}{c}0.049 \\
(0.088)\end{array}$ \\
\hline Observations & 57739 & 14158 & 120231 & 13257 & 20872 & 73359 & 27138 & 3187 \\
\hline Fixed Effects & No & No & No & No & No & No & No & No \\
\hline Covariates & Yes & Yes & Yes & Yes & Yes & Yes & Yes & Yes \\
\hline Occupation FE & No & No & No & No & No & No & No & No \\
\hline \multicolumn{9}{|c|}{ Panel C: plus occupation controls } \\
\hline Baby Boomers & $\begin{array}{c}0.026^{* *} \\
(0.012)\end{array}$ & $\begin{array}{c}-0.010 \\
(0.019)\end{array}$ & $\begin{array}{l}0.110^{* * *} \\
(0.009)\end{array}$ & $\begin{array}{l}0.082^{* *} \\
(0.032)\end{array}$ & $\begin{array}{c}0.021 \\
(0.023)\end{array}$ & $\begin{array}{c}-0.041^{* * *} \\
(0.008)\end{array}$ & $\begin{array}{c}-0.114^{* * *} \\
(0.017)\end{array}$ & $\begin{array}{c}-0.041 \\
(0.047)\end{array}$ \\
\hline Gen. X. & $\begin{array}{c}0.037^{* *} \\
(0.015)\end{array}$ & $\begin{array}{c}-0.008 \\
(0.024)\end{array}$ & $\begin{array}{l}0.159^{* * *} \\
(0.011)\end{array}$ & $\begin{array}{l}0.150^{* * *} \\
(0.038)\end{array}$ & $\begin{array}{c}-0.007 \\
(0.027)\end{array}$ & $\begin{array}{c}-0.099^{* * *} \\
(0.011)\end{array}$ & $\begin{array}{c}-0.123^{* * *} \\
(0.021)\end{array}$ & $\begin{array}{c}-0.059 \\
(0.063)\end{array}$ \\
\hline Millennials & $\begin{array}{c}-0.001 \\
(0.019)\end{array}$ & $\begin{array}{c}-0.067^{*} \\
(0.039)\end{array}$ & $\begin{array}{l}0.150^{* * *} \\
(0.014)\end{array}$ & $\begin{array}{l}0.124^{* * *} \\
(0.045)\end{array}$ & $\begin{array}{c}-0.062^{*} \\
(0.035)\end{array}$ & $\begin{array}{c}-0.153^{* * *} \\
(0.018)\end{array}$ & $\begin{array}{c}-0.159^{* * *} \\
(0.028)\end{array}$ & $\begin{array}{c}0.128 \\
(0.085)\end{array}$ \\
\hline Observations & 57739 & 14158 & 120231 & 13257 & 20872 & 73359 & 27138 & 3187 \\
\hline Fixed Effects & No & No & No & No & No & No & No & No \\
\hline Covariates & Yes & Yes & Yes & Yes & Yes & Yes & Yes & Yes \\
\hline Occupation FE & Yes & Yes & Yes & Yes & Yes & Yes & Yes & Yes \\
\hline & (1) & $(2)$ & $\begin{array}{c}\text { Panel D } \\
(3)\end{array}$ & $\begin{array}{l}\text { Plus state f } \\
\text { (4) }\end{array}$ & $\begin{array}{l}\text { effects } \\
(5)\end{array}$ & (6) & (7) & (8) \\
\hline Baby Boomers & $\begin{array}{l}0.026^{* *} \\
(0.011)\end{array}$ & $\begin{array}{r}-0.007 \\
(0.019)\end{array}$ & $\begin{array}{l}0.116^{* * *} \\
(0.013)\end{array}$ & $\begin{array}{l}0.094^{* * * *} \\
(0.034)\end{array}$ & $\begin{array}{c}0.022 \\
(0.025)\end{array}$ & $\begin{array}{l}-0.035^{* * *} \\
(0.011)\end{array}$ & $\begin{array}{l}-0.107^{* * *} \\
(0.024)\end{array}$ & $\begin{array}{c}-0.036 \\
(0.064)\end{array}$ \\
\hline Gen. X. & $\begin{array}{l}0.038^{* *} \\
(0.017)\end{array}$ & $\begin{array}{c}-0.002 \\
(0.026)\end{array}$ & $\begin{array}{l}0.169^{* * *} \\
(0.015)\end{array}$ & $\begin{array}{l}0.166^{* * *} \\
(0.042)\end{array}$ & $\begin{array}{c}-0.005 \\
(0.031)\end{array}$ & $\begin{array}{c}-0.087^{* * *} \\
(0.015)\end{array}$ & $\begin{array}{c}-0.113^{* * *} \\
(0.025)\end{array}$ & $\begin{array}{c}-0.050 \\
(0.069)\end{array}$ \\
\hline Millennials & $\begin{array}{c}0.002 \\
(0.019) \\
\end{array}$ & $\begin{array}{c}-0.055 \\
(0.051)\end{array}$ & $\begin{array}{l}0.164^{* * *} \\
(0.022)\end{array}$ & $\begin{array}{l}0.138^{* * *} \\
(0.045)\end{array}$ & $\begin{array}{c}-0.060^{*} \\
(0.032)\end{array}$ & $\begin{array}{c}-0.140^{* * *} \\
(0.023)\end{array}$ & $\begin{array}{c}-0.141^{* * *} \\
(0.036)\end{array}$ & $\begin{array}{c}0.136 \\
(0.094)\end{array}$ \\
\hline Observations & 57739 & 14158 & 120231 & 13257 & 20872 & 73359 & 27138 & 3186 \\
\hline Fixed Effects & Yes & Yes & Yes & Yes & Yes & Yes & Yes & Yes \\
\hline Covariates & Yes & Yes & Yes & Yes & Yes & Yes & Yes & Yes \\
\hline Occupation FE & Yes & Yes & Yes & Yes & Yes & Yes & Yes & Yes \\
\hline
\end{tabular}

Note: Each panel and column is a regression where the dependent variable is log wage as seen in Equation (3). Panel A is the regression without covariates and fixed effects. Panel B includes covariates but not fixed effects. Panel C includes additional occupation controls. Panel D is the full specification including all covariates and state fixed effects. The data from the CPS and BEA are merged at the state geographic level and 1 digit industry code as described in Appendix A. The generation variables are all dummy variables defined on the basis of date of birth, as per Table 1. The omitted category is the Silent Generation. Covariates include age, education, gender and race variables. Fixed effects are by state. Standard errors are in parenthesis. ${ }^{* * *}$ Significant at the $1 \%$ level.** Significant at the $5 \%$ level. ${ }^{*}$ Significant at the $10 \%$ level. 